\title{
Girls Creating Opportunities for a Brighter Tomorrow: Integrated Curriculum Guide (8 to 17 years old)-Two-year cycle (adapted for Belize)
}

Cecilia Garcés

Population Council

Paola Broll

Population Council

Follow this and additional works at: https://knowledgecommons.popcouncil.org/departments_sbsr-pgy

Part of the Demography, Population, and Ecology Commons, Family, Life Course, and Society Commons, Indigenous Studies Commons, and the International Public Health Commons How does access to this work benefit you? Let us know!

\section{Recommended Citation}

Garcés, Cecilia and Paola Broll. 2017. "Girls Creating Opportunities for a Brighter Tomorrow: Integrated Curriculum Guide (8 to 17 years old)-Two-year cycle (adapted for Belize)." New York: Population Council. 


\section{POPULATION \\ Powner \\ Ideas. Evidence. Impact.}

The Population Council is an international, nonprofit, nongovernmental organization that seeks to improve the well-being and reproductive health of current and future generations around the world and to help achieve a humane, equitable, and sustainable balance between people and resources.

The Population Council conducts research to address critical health and development issues. We are working to stop the spread of HIV, provide more reproductive choices, and ensure that young people lead full and productive lives. Our research leads to better policies, programs, and technologies that improve lives around the world.

\section{Population Counci}

One Dag Hammarskjold Plaza

New York, NY 10017

Tel: 212-339-0500

Fax: 212-775-6092

www.popcouncil.org

Email: publications@popcouncil.org

\section{Acknowledgments to donors: NIKE, SUMMIT, UNFPA}

Girls Creating Opportunities for a Brighter Tomorrow: Integrated Curriculum Guide consists of seven modules (1 introduction and 6 session development).

(c)2017 The Population Council, Inc.

\section{Credits}

Authors: María Cecilia Garcés de Marcilla, Education \& Curriculum Specialist Paola Broll, Program Officer

Revisions: Alejandra Munguia, Field Coordinator María José Aldana

Translation to English: Heather Wehr, Regina Solís, María José Aldana

Design and layout: Isaí de la Cruz and James De Groat

Population Council Team 2015:

Country Director: Alejandra Colom

Office Manager: Ana Lucía Rodríguez

Program Officer: Paola Broll

Field Coordinator: Alejandra Munguía

Education \& Curriculum Specialist: Cecilia Garcés

Monitoring and Evaluation Supervisor and Program Officer: Ángel del Valle

Toledo Maya Women's Council: Amira Teul

Community Mentors: Elizabeth Vásquez, Rosa Güit, Fabiola Colop, Sonia Cho and Claudia Macz 
Introduction.....................................................................

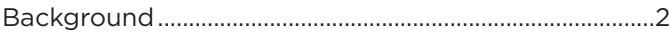

Education from the Human Rights and Gender perspectives........................................................................

Girls and adolescents in the spotlight ..............................

Cascading participatory structure......................................

Curriculum guide structure ...................................................

Topic delivery according to age group............................ 6

4 step methodology ............................................................... 8

Using this curriculum guide .............................................. 8

\section{MODULE 1: YEAR 1}

.. .9

\section{MODULE 1 (Group ages 8 to 12).}

2) Nutrition and the needs of a girl, adolescent

and a woman ....................................................... 15

1.3) I know and love myself...............................................18

1.4) I am valuable for who I am ......................................10

1.5) I have rights that protect me......................10

MODULE 1: (Group ages 13 to 17) ..............................30

1.1) Our safe space: getting along with women .........30

1.2) Nutrition and a woman's needs ................................35

1.3) I know and value myself .............................................. 37

1.4) I am valuable for who I am .......................................... 41

1.5) Human Rights value my self-esteem .......................45

MODULE 2: YEAR 1

MODULE 2 (Group ages 8 to 12)

2.3) The importance of saving money ...........................70

2.4) Building my life: job options ................................... 74

2.5) I express myself assertively .......................................76

2.6) I recognize when and where I am in danger .....79

\section{MODULE 3: YEAR}

\section{MODULE 3 (Group ages 8 to 12)}

3.1) Health and hygiene.

3.2) Changes in our body as we grow .......................... 90

3.3) The menstrual cycle ...................................................93

3.4) I am a girl and I can!.................................................99

3.5) My girlfriends and I have a lot in common ....... 102

\section{MODULE 3 (Group ages 13 to 17)}

3.1) Health in youth and motherhood..........................104

3.2) What are our sexual organs like?

3.3) Body changes during puberty and the menstrual cycle .........................................................111

3.4) What is it like to be a woman? How were we taught to be women? ...............................................120

3.5) Sisterhood: A new way for woman to relate to each other .............................................................125

3.6) I respect dignity when I communicate ............... 130

\section{MODULE 4: YEAR 2} .133

\section{MODULE 4 (Group ages 8 to 12)} . .134

4.1) What are the safe spaces in my community?.....135

4.2) Eating and Eating Nutritiously are not the same

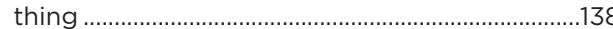

4.3) I can protect my body ........................................... 142

4.4) Pregnancy, decisions and family planning ………................................................ 145

2.2) I have to choose the best option .............. 55

2.3) I see nearby dangers..................................................58

2.4) My family cares about me and can support.... 60

MODULE 2 (Group ages 13 to 17)

62

2.1) My needs: scarcity and my expenses ....................62

2.2) Economic justice, power and rights .................66
4.5) I express myself assertively

\section{MODULE 4 (Group ages 13 to 17).}

151

4.1) I build safe spaces in my community ....................15

4.2) Health: Nutrition ..........................................................155
4.3) Fertility, fertilization and pregnancy ...................158

4.4) Sexual and Reproductive Rights .......................... 163

4.5) We are many diverse women working

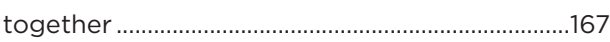

MODULE 5: YEAR 2 ….............................................170

MODULE 5 (Group ages 8 to 12)

171

5.1) I save money for my wellbeing …………………....172

5.2) I save money for my wellbeing (part II) .............174

5.3) I can make decisions to protect myself...............175

5.4) Changing violence to respect between men and women ..........................................................178

\section{MODULE 5 (Group ages 13 to 17)}

182

5.1) Who pays for public services? .................................182

5.2) Financial credit: A matter of responsibility.......185

5.3) In this community, we overcome obstacles..... 188

5.4) Changing violence to respect between men

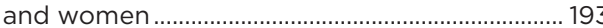

5.5) Community outreach: Facing each other ..........196

5.6) My community's needs .......................................... 198

\section{MODULE 6: YEAR 2} 200

MODULE 6 (Group ages 8 to 12)

201

6.1) Girls' rights in my community .............................. 202

6.2) My community's needs ..........................................204

6.3) I imagine what I can accomplish in my life ..... 207

6.4) My gift to the community ........................................ 210

\section{MODULE 6 (Group ages 13 to 17)}

212

6.1) I make my own decisions ............................................212

6.2) Learning about STIs and HIV/AIDS ...................... 216

6.3) Family planning ……...................................................222

6.4) I am a contribution to development....................226

6.5) My life plan and my contribution to the community 228 
The Population Council conducts research to address critical health and development issues. These issues range from stopping the spread of HIV to improving reproductive health and ensuring that young people have a full and productive life. Through our research efforts, we design, implement and evaluate programs for adolescent girls in developing countries, with a special focus on Africa, Asia and Latin America.

Over the past decade, the Council's research shows that adolescent girls living in contexts of poverty and isolation, such as the rural areas of Guatemala, tend to leave school around age 12 (Hallman, Peracca, Catino, \& Ruiz, 2006). Lack of money and household duties are frequently mentioned as principal constraints by females between ages 13 to 24 years who are not studying. Most families in these settings expect that young girls marry or have children to become productive in the community. Together with child early forced unions and marriage and unintended pregnancies, girls face migration, human trafficking and gender based violence.

Based on the evidence generated through research, the Population Council designed a program for adolescent girls in Guatemala's rural indigenous communities called Girls Creating Opportunities for a Brighter Tomorrow.

The program creates safe spaces for girls at the community level and reaches adolescent girls with an asset-based curriculum implemented by a community mentor- a young woman from the community that serves as an alternative role model for girls. The program has been running for twelve years, and has reached close to 8,000 adolescent girls in 150 communities. In 2017, a similar program called Girls Creating Opportunities for a Better Tomorrow, started to be implemented in Belize, based on the Abriendo Oportunidades program.

This program is community based, and starts off by an arrangement made with the local leaders who agree to guarantee support for participating girls and adolescents as well as the mentors. After acquiring the community's support, the girl rooster is conducted through a community mapping process, in order to identify all the girls aged 8 to 18 in the community and identify the venue where the safe space will be set up for participants to meet on a weekly basis. Afterwards al identified girls and adolescents are invited to enroll in Girls Creating Opportunities for a Brighter Tomorrow and participate in weekly sessions held in the safe space. These meetings are organized and led by the community mentors, who are periodically trained by the Population Council through the mentor training component.

This guide follows three approaches: 1) Human Rights, 2) Gender, and 3) Cultural Relevance. Through the exploration of eight domains, girls and adolescent develop their knowledge, abilities and attitudes. Girls Creating Opportunities for a Brighter Tomorrow proposes six modules, organized in quarters, in order to achieve the 18 months defined by the Council as the minimum dose of exposure to the program needed to achieve specific outcomes.

More than a decade of work in Guatemala demonstrates that girls who participate in the program stay longer in school, overcome fear to participate in community activities, increase their self-esteem, learn new skills, and widen their local network of friends and role-models. Approaching all members in the community has proven to motivate communities to support girls and adolescents by investing in their education and believing in their life goals. When participating in the program, girls and families are healthier and happier. 
In 2004, the Population Council in Guatemala launched the 'Abriendo Oportunidades' Program with the purpose of supporting indigenous girls in reaching their maximum potential to overcome the cycle of poverty (Catino, Colom, \& Ruiz, 2011). During these 12 years, the program compiled many valuable lessons, many times from young mentors working directly with girls and adolescents. Constant dialogue amongst the Council's team led to the current version of the curriculum guide. This guide desinged with the assets-building approach that prevents gender-based violence, promotes human rights and integrates comprehensive sexuality education.

This is the third version of the AO curriculum. The first two versions focused mainly on reproductive health, nutrition, hygiene, communication skills, and financial education. Several of the initial topics, as well as some activities from these previous versions, are still included in the current version. The previous volumes of the guide divided content into two age groups: 8 to 12 and 13 to 17. However, implementation experiences made evident the need to include new topics and establish new cross-cutting approaches to strenghten the methodology.

The Council's mentoring team together with the education specialist and program officer reviewed the guide through a participatory approach with the purpose of adapting objectives, content and activities to the context of rural indigenous adolescent girls in Guatemala. As a result, Gender, Human Rights and Cultural Relevance were set as underlying approaches, new topics, such as financial education were introduced, violence prevention and sexual rights were enhanced and an easy to follow four step methodology was designed to foster mentoring skills.
In order to introduce mentors in the use of the guide and its' methodology the Mentor Training Component was designed. This component ensured that mentors went through a formative process to enhance their own knowledge and abilities, based on participatory methods that went beyond guide sessions in a series of combined of activities that include: study trainings, monthly meetings and an appreciation guide mentors. This process lasts a bit more that the 18 months required to implement the guide and intends for progressive autonomy of mentors.

The guide was designed as a tool to foster reflection and dialogue, sisterhood and critical thinking among adolescent girls. Therefore, we promote it as a valuable tool for programs that seek to integrate comprehensive sexuality education and the prevention of violence to their approach. 


\section{EDUCATION FROM THE HUMAN RIGHTS AND GENDER PERSPECTIVES}

The AO curriculum guide is based on the following Human Rights and Gende based principles:

- Every girl and adolescent is a citizen

- Human rights are minimum life conditions everyone should access and enjoy in order to lead full productive lives.

- Guatemalan state guarantees human rights universally.

- Violence, in any form, is unacceptable. It has a negative impact on girls, adolescents, their families and community. It can and should be prevented and eliminated.

- It is possible to overcome the disadvantaged conditions in which girls, adolescents and women live in, this is a shared responsibility between individuals, families and communities.

- Access to education, nutrition, health, social network and other resources strengthens girls' adolescents' and women's autonomy improving their lives as well as the lives of their families and communities.

- Girls and adolescents are capable and entitled to participate as leaders in their families and communities.

Girls Creating Opportunities for a Brighter Tomorrow places girls and adolescents at the center of the program, and bases its educational model on providing quality education which is the door for the fulfillment of other human rights. This comprehensive approach will result in girls, and adolescents with better self-esteem who are inspired to participate as active citizens in the fulfillment of their rights.

\section{GIRLS AND ADOLESCENTS IN THE SPOTLIGHT:}

All over the world, adolescent girls from indigenous communities face more disadvantages than their non-indigenous peers and suffer from discrimination based on a racist, patriarchal, and adult-centric view of the world. The violation of their human rights through limited educational, nutritional and economic opportunities translate to high rates of mortality, forced and early child marriage/unions, gender based violence and forced migration. In Guatemala girls face these conditions on a daily basis:

- $\quad 81 \%$ live in poverty

- Two out of three live in rural areas that lack basic services

- By the age of 17 , only $26 \%$ are in the school system

- $31 \%$ participate in the labor market

- $40 \%$ become wives before age 18

- $54 \%$ will have a child before age 20

- $\quad 25 \%$ of all pregnancies correspond to girls between ages 10 and 19

- Unicef 2008, Unicef 2009, Hallman et.al. 2007, Sewal-Menon et al., 2012, ICEFI and UNICEF 2013
In such contexts, the age of transition between childhood and adolescence is often when girls leave school, become wives and have children. Evidence shows that indigenous girls living in extreme poverty have the highest dropout rates beginning at age 12. Population Council qualitative studies show that girls and women quote household chores and economic limitations as the main reasons for school dropout. Because family expectations dictate that girls should continue developing their skills in the domestic environment it doesn't make sense to invest in their education after puberty (Catino, Hallman, Peracca, \& Ruiz, 2006). Also, within traditional family valuse, the interaction between adolescents of both sexes represents a growing concern which limits adolescent girls presence and participation in the education system (Colom et al., 2004).

Girls Creating Opportunities for a Brighter Tomorrow focuses its efforts around the particular needs of girls and adolescents, through a safe space platform where they can consolidate their social networks and develop key assets. Despite all the evidence, our research proved that rural indigenous girls have access to few social programs. (Catino, Colom \& Ruiz, 2011). Therefore, we focus on reaching girls that are left behind both at the national and community levels: migrant, out of school, in forced marriages or early motherhood.

\section{CASCADING PARTICIPATORY STRUCTURE}

Girls Creating Opportunities for a Brighter Tomorrow promotes a cascade leadership approach at the community and municipal levels, where girls and adolescents participate in three different roles and levels:

\section{Girls and Adolescent Girls Groups}

Grouped according to their age, girls and adolescents meet weekly with community mentors for a period of 18 months. They follow a culturally relevant, rights-based curriculum that builds life skills and assets, including communication skills, knowledge of their rights, tools to question traditional gender norms as well as sexual and reproductive rights and health.

Girls are first identified by the girl roster developed through the community mapping process, after which they are invited to participate in the girl group through community meetings and home visits. Participation is free and the only requirement is to be a girl or an adolescent. Gradually, girls expand their network of friends, learn new topics and develop handcraft skills.

\section{Community Mentors}

Mentors are local women ages 18 - 25 with similar background to that of the girls and adolescents. They are at the center of the Mentor Training Component, aiming to ensure their facilitation skills and knowledge. Together with leading weekly meetings in safe spaces with girls and adolescents, mentors have an active role in negotiations with local authorities to ensure their support in providing the safe space. These young women guide and support the groups of girls and become their role models. 
By meeting and building friendships with other mentors, these young women also strengthen their social skills. In order to support the community mentor in her own development, she participates in the Mentor training component, community mapping and advocacy activities.

\section{Monitoring Mentors}

The monitoring mentors are young women that started as community mentors in their community. The monitoring mentors accompany the community mentors in their weekly activities to offer feedback and support in monitoring, administrative, advocacy and facilitation issues. They are motivated to advance their education in order to be able to achieve greater autonomy in their lives. They also participate in meetings with community leaders to guarantee that their support to the program is sustained throughout the implementation of the program.

\section{Safe Spaces}

The program keeps girls and adolescents at the center while also engaging parents, guardians, and community leaders. By convening through a community contract, local leaders commit to support girls and adolescents offering a local venue in which mentors will lead the sessions. This place becomes a safe space for participants to meet in every week as it is the time and place in which girls and adolescents gather, learn, foster a network and develop sisterhood.

In order to learn in a meaningful way, it is important for girls to have the opportunity to make mistakes, be authentic and communicate in a profound manner. To enable this environment, it is critical to promote a feeling of safety where participants can communicate with each other without being judged.

Overall, a safe space should offer the opportunity to foster sisterhood, allowing girls to relate with each other based on their similar experiences and generate collective support. The safe space goes beyond the physical layout of the space, as well as its surroundings and accessibility. It is meant to be the time and place for girls and adolescents to develop autonomy, leadership, life skills, life plans and have a healthy social network.

\section{What girls and adolescents value the most!}

Evaluations conducted to determine the impact of the Girls Creating Opportunities for a Brighter Tomorrow ${ }^{\circledR}$ program document that girls and adolescents who participate value their new skills, acquire important knowledge for their daily lives, and establish life plans. Another outcome observed as a result of participating is a higher number of girls enrolled in school at the community level, which suggests a transformation in the cultural norms that reproduce negative gender norms. Formative research conducted confirms this, as one of the mentors said:

In the past, they [our parents] let my brother go to school because he was a boy, but they didn't let me go. But now, I have shown them (I think I have shown my parents) that I can do it. Because in the past... my father used to say to me that when I finished sixth grade: "you're not going to study", and so it was that way. But, when this program started, they gave me the opportunity to study and now I have goals and I want to graduate. - Girl leader, Solola (Catino et. al. 2011)

A participatory exercise collected stories from participating adolescents in AO. The analysis of these found that participants rank the following four outcomes as the most valuable for their lives:

1. Increased self-esteem

2. Overcomes fear to participate in public activities

3. Increased number of friends

4. Increased knowledge of sexual health and reproductive health

The following is a proposal of time periods in which participants may show achievements on these four outcomes.

\begin{tabular}{|c|l|l|l|}
\hline $\begin{array}{c}\text { OUTCOME } \\
\text { INDICATOR }\end{array}$ & \multicolumn{1}{|c|}{$\mathbf{6}$ months } & \multicolumn{1}{|c|}{$\mathbf{1}$ year } & \multicolumn{1}{c|}{ years } \\
\hline Self-esteem & $\begin{array}{l}\text { Identifies what she } \\
\text { can do well. } \\
\text { Recognizes her own } \\
\text { strengths. } \\
\text { Values herself } \\
\text { compared to others. }\end{array}$ & $\begin{array}{l}\text { Takes care of her } \\
\text { hygiene and } \\
\text { personal image. } \\
\text { Responds to and } \\
\text { defends herself from } \\
\text { insults. } \\
\text { Makes her own } \\
\text { decisions. }\end{array}$ & $\begin{array}{l}\text { Knows strategies } \\
\text { to strengthen other } \\
\text { women's self-esteem. } \\
\text { Establishes midterm } \\
\text { and long-term goals } \\
\text { for her life. } \\
\text { Writes her life plan. }\end{array}$ \\
\hline $\begin{array}{c}\text { Overcomes } \\
\text { fear to partic- } \\
\text { ipate in public } \\
\text { activities }\end{array}$ & $\begin{array}{l}\text { Shares her testimony. } \\
\text { Speaks in public. } \\
\text { Asks her family for } \\
\text { permission. }\end{array}$ & $\begin{array}{l}\text { Defends her own } \\
\text { interests and goals. } \\
\text { Expresses feelings in } \\
\text { front of others. } \\
\text { Unafraid of being } \\
\text { teased. }\end{array}$ & $\begin{array}{l}\text { Applies negotiation } \\
\text { strategies. } \\
\text { Does not allow teasing } \\
\text { or gossip concerning } \\
\text { peers. Participates in } \\
\text { community activities. }\end{array}$ \\
\hline $\begin{array}{c}\text { Increase } \\
\text { number of } \\
\text { friends }\end{array}$ & $\begin{array}{l}\text { Identifies the groups } \\
\text { she belongs to. } \\
\text { Likes to play with } \\
\text { other girls. } \\
\text { Wants to learn new } \\
\text { things. }\end{array}$ & $\begin{array}{l}\text { Develops sisterhood } \\
\text { and supports other } \\
\text { girls. } \\
\text { Relates with } \\
\text { different people. } \\
\text { Is aware of her gender. }\end{array}$ & $\begin{array}{l}\text { Takes on leadership. } \\
\text { Knows new places. } \\
\text { Can communicate } \\
\text { with community }\end{array}$ \\
leaders. \\
\hline $\begin{array}{c}\text { Sexual and } \\
\text { reproductive } \\
\text { health }\end{array}$ & $\begin{array}{l}\text { Can speak about her } \\
\text { body without feeling } \\
\text { ashamed. } \\
\text { Explains the changes } \\
\text { that her body goes } \\
\text { through. } \\
\text { Correctly names her } \\
\text { body parts. }\end{array}$ & $\begin{array}{l}\text { Knows her sexual and } \\
\text { reproductive rights. } \\
\text { Knows the risks of } \\
\text { having sexual } \\
\text { intercouse. } \\
\text { Defends her right to } \\
\text { nutrition. }\end{array}$ & $\begin{array}{l}\text { Makes decisions } \\
\text { regarding her body. } \\
\text { Does not accept vio- } \\
\text { lence against her body } \\
\text { and self as normal. } \\
\text { Knows how to prevent } \\
\text { diseases, infections } \\
\text { and unwanted } \\
\text { pregnancy. }\end{array}$ \\
\hline
\end{tabular}




\section{CURRICULUM GUIDE STRUCTURE}

The curriculum guide is based on eight subject domains:

1. “Girls Creating Opportunities for a Brighter Tomorrow". Participants work on the concept of safe spaces, women's relationships with these safe spaces and the possibility of preventing violence in the community.

2. Personal strengthening. Participants reflect on their identity, self-esteem, social skills and life plan.

3. Community Outreach. Participants identify their own strengths to serve and work for the development of their community.

4. Health. Participants learn about nutrition, women's health and disease prevention.

5. Sexual Health and Reproductive Health. Participants learn detailed information regarding menstruation, dating and family planning.

6. Financial Education. Participants learn to identify their participation in the economy, resource management and civic responsibility.

7. Violence prevention. Participants recognize types of violence, get to know legal codes and develop strategies for violence prevention.

8. Gender. Participants learn the difference between sex and gender, as well as ideas and traditions related to gender that affect their access to opportunities for development.

These domains are weaved into six modules lasting approximately three months each, to be implemented in 18 months organized as follows:

\begin{tabular}{|c|c|}
\hline Year 1 & Year 2 \\
\hline Quarter I & Quarter I \\
\hline $\begin{array}{l}\text { Girls Creating Opportunities for a } \\
\text { Brighter Tomorrow } \\
\text { Health } \\
\text { Personal strengthening }\end{array}$ & $\begin{array}{l}\text { Girls Creating Opportunities for a } \\
\text { Brighter Tomorrow } \\
\text { Health } \\
\text { Sexual Health and Reproductive Health } \\
\text { Gender } \\
\text { Personal strengthening }\end{array}$ \\
\hline Quarter II & Quarter II \\
\hline $\begin{array}{l}\text { Financial Education } \\
\text { Violence Prevention } \\
\text { Personal Strengthening }\end{array}$ & $\begin{array}{l}\text { Financial Education } \\
\text { Violence Prevention } \\
\text { Community Outreach } \\
\text { Gender } \\
\end{array}$ \\
\hline Quarter III & Quarter III \\
\hline $\begin{array}{l}\text { Sexual and Reproductive Health } \\
\text { Gender } \\
\text { Personal Strengthening }\end{array}$ & $\begin{array}{l}\text { Sexual and Reproductive Health } \\
\text { Personal Strengthening } \\
\text { Community Outreach }\end{array}$ \\
\hline
\end{tabular}


TOPIC DELIVERY ACCORDING TO AGE GROUP

\begin{tabular}{|c|c|c|c|c|c|c|c|c|c|c|c|c|c|}
\hline \multirow[b]{2}{*}{ Year } & \multirow[b]{2}{*}{ Module } & \multirow[b]{2}{*}{ Topic Domain } & \multirow[b]{2}{*}{ Topic } & \multicolumn{10}{|c|}{ Ages to work with } \\
\hline & & & & 8 & 9 & 10 & 11 & 12 & 13 & 14 & 15 & 16 & 17 \\
\hline \multirow{30}{*}{1} & \multirow{9}{*}{1} & \multirow{2}{*}{$\begin{array}{c}\text { Girls Creating } \\
\text { Opportunities For A } \\
\text { Brighter Tomorrow }\end{array}$} & Our safe space: getting along with other girls & $*$ & * & * & * & $*$ & & & & & \\
\hline & & & Our safe space: getting along with women & & & & & & * & $*$ & * & * & * \\
\hline & & \multirow[t]{2}{*}{ Health } & $\begin{array}{l}\text { Nutrition and the needs of girls, } \\
\text { adolescent girls and women }\end{array}$ & $*$ & * & * & $*$ & $*$ & & & & & \\
\hline & & & Nutrition and a woman's needs & & & & & & * & $*$ & $*$ & $*$ & * \\
\hline & & \multirow{5}{*}{ Personal Strengthening } & I know and love myself & $*$ & $*$ & * & $*$ & $*$ & & & & & \\
\hline & & & I know and value myself & & & & & & * & $*$ & * & $*$ & * \\
\hline & & & I am valuable for who I am & $*$ & * & * & $*$ & $*$ & * & $*$ & * & * & * \\
\hline & & & I have rights that protect me & $*$ & * & $*$ & $*$ & $*$ & & & & & \\
\hline & & & Human rights value my self-esteem & & & & & & * & $*$ & * & * & * \\
\hline & \multirow{10}{*}{ II } & \multirow{6}{*}{$\begin{array}{l}\text { Financial } \\
\text { Education }\end{array}$} & I give to receive & $*$ & $*$ & * & $*$ & $*$ & & & & & \\
\hline & & & I have to choose the best option & $*$ & * & * & $*$ & $*$ & & & & & \\
\hline & & & My needs: scarcity and my expenses & & & & & & * & $*$ & * & * & * \\
\hline & & & Economic justice, power and rights & & & & & & * & $*$ & $*$ & $*$ & $*$ \\
\hline & & & The importance of saving money & & & & & & * & $*$ & $*$ & $*$ & * \\
\hline & & & Building my life: job options & & & & & & * & $*$ & * & $*$ & * \\
\hline & & Personal Strengthening & My family cares about me and can support me & $*$ & * & * & $*$ & $*$ & & & & & \\
\hline & & \multirow{3}{*}{ Violence Prevention } & I see the nearby dangers & $*$ & $*$ & $*$ & $*$ & $*$ & & & & & \\
\hline & & & I express myself assertively & & & & & & * & $*$ & * & $*$ & * \\
\hline & & & I recognize when and where I am in danger & & & & & & * & $*$ & * & $*$ & * \\
\hline & \multirow{11}{*}{ III } & \multirow{6}{*}{$\begin{array}{l}\text { Sexual Health and } \\
\text { Reproductive Health }\end{array}$} & Girls' health and our body & $*$ & * & * & * & $*$ & & & & & \\
\hline & & & Sexual Health and Reproductive Health & & & & & & * & $*$ & * & $*$ & * \\
\hline & & & What are our sexual organs like? & & & & & & * & $*$ & * & $*$ & * \\
\hline & & & Changes in our body as we grow & * & * & * & $*$ & * & & & & & \\
\hline & & & The menstrual cycle & $*$ & $*$ & * & * & $*$ & & & & & \\
\hline & & & Body changes during puberty and the menstrual cycle & & & & & & * & $*$ & * & * & * \\
\hline & & \multirow{4}{*}{ Gender } & I am a girl and I can! & * & $*$ & * & * & * & & & & & \\
\hline & & & $\begin{array}{l}\text { What is it like to be a woman? How were we taught to } \\
\text { be women? }\end{array}$ & & & & & & * & $*$ & * & $*$ & * \\
\hline & & & My girlfriends and I have a lot in common & $*$ & $*$ & * & * & $*$ & & & & & \\
\hline & & & $\begin{array}{l}\text { Sisterhood: A new way for women to relate with each } \\
\text { other }\end{array}$ & & & & & & * & * & * & * & * \\
\hline & & Personal Strengthening & I respect dignity when I communicate & & & & & & * & $*$ & * & * & * \\
\hline
\end{tabular}




\section{TOPIC DELIVERY ACCORDING TO AGE GROUP}

\section{(CONTINUED)}

\begin{tabular}{|c|c|c|c|c|c|c|c|c|c|c|c|c|c|}
\hline \multirow[b]{2}{*}{ Year } & \multirow[b]{2}{*}{ Module } & \multirow[b]{2}{*}{ Topic Domain } & \multirow[b]{2}{*}{ Topic } & \multicolumn{10}{|c|}{ Ages to work with } \\
\hline & & & & 8 & 9 & 10 & 11 & 12 & 13 & 14 & 15 & 16 & 17 \\
\hline \multirow{29}{*}{2} & \multirow{10}{*}{ IV } & \multirow{2}{*}{$\begin{array}{c}\text { Girls Creating } \\
\text { Opportunities For A } \\
\text { Brighter Tomorrow }\end{array}$} & Which are the safe spaces in my community? & ${ }^{*}$ & * & * & * & * & & & & & \\
\hline & & & I build safe spaces in my community & & & & & & * & * & $*$ & $*$ & * \\
\hline & & \multirow{2}{*}{ Health } & Eating and Eating Nutritiously are not the same thing & * & $*$ & $*$ & * & * & & & & & \\
\hline & & & Nutrition & & & & & & * & * & * & $*$ & * \\
\hline & & \multirow{4}{*}{$\begin{array}{l}\text { Sexual Health and } \\
\text { Reproductive Health }\end{array}$} & I can protect my body & * & $*$ & $*$ & * & $*$ & & & & & \\
\hline & & & Pregnancy, decisions and family planning & & & & & & * & ${ }^{*}$ & * & * & * \\
\hline & & & Fertility, fertilization and pregnancy & * & $*$ & * & * & $*$ & $*$ & * & $*$ & $*$ & * \\
\hline & & & Sexual and reproductive Rights & * & $*$ & * & * & * & & & & & \\
\hline & & Personal Strengthening & I communicate assertively & ${ }^{*}$ & * & * & * & * & & & & & \\
\hline & & Gender & We are many diverse women working together & & & & & & * & * & * & * & * \\
\hline & \multirow{10}{*}{$\mathrm{V}$} & \multirow{4}{*}{$\begin{array}{l}\text { Financial } \\
\text { Education }\end{array}$} & I save money for my wellbeing | & * & $*$ & $*$ & * & $*$ & & & & & \\
\hline & & & I save money for my wellbeing || & ${ }^{*}$ & * & * & * & * & & & & & \\
\hline & & & Who pays for public services? & & & & & & * & * & * & * & * \\
\hline & & & Financial credit: a matter of responsibility & & & & & & * & ${ }^{*}$ & * & $*$ & * \\
\hline & & \multirow{4}{*}{ Violence Prevention } & I can make decisions to protect myself & * & $*$ & * & * & * & & & & & \\
\hline & & & $\begin{array}{l}\text { Changing violence for respect between men } \\
\text { and women }\end{array}$ & & & & & & $*$ & * & * & $*$ & * \\
\hline & & & In this community, we overcome obstacles & & & & & & $*$ & $*$ & $*$ & $*$ & * \\
\hline & & & $\begin{array}{l}\text { Violence prevention: Violence is fought with } \\
\text { intelligence, courage and our friends }\end{array}$ & & & & & & $*$ & * & * & $*$ & * \\
\hline & & \multirow{2}{*}{ Community Outreach } & Facing each other & & & & & & * & * & * & $*$ & * \\
\hline & & & My community's needs & & & & & & * & $*$ & $*$ & $*$ & * \\
\hline & \multirow{9}{*}{$\mathrm{VI}$} & \multirow{3}{*}{$\begin{array}{l}\text { Sexual Health and } \\
\text { Reproductive Health }\end{array}$} & I make my own decisions & & & & & & $*$ & * & * & $*$ & * \\
\hline & & & Learning about STIs and HIV/AIDS & & & & & & ${ }^{*}$ & * & * & * & * \\
\hline & & & Family planning & & & & & & * & * & * & * & * \\
\hline & & \multirow{6}{*}{ Community Outreach } & Girls' rights in my community & ${ }^{*}$ & * & * & * & * & & & & & \\
\hline & & & My community's needs & ${ }^{*}$ & * & * & * & * & & & & & \\
\hline & & & I imagine what I can accomplish in my life & * & $*$ & $*$ & * & $*$ & & & & & \\
\hline & & & My gift to the community & * & $*$ & * & * & $*$ & & & & & \\
\hline & & & I'm a contribution to development & & & & & & ${ }^{*}$ & * & * & * & * \\
\hline & & & My life plan and my contribution to the community & & & & & & * & * & * & * & * \\
\hline
\end{tabular}




\section{STEP METHODOLOGY}

Girls Creating Opportunities for a Brighter Tomorrow makes girls and adolescents look into their own lives in order to identify the roots of issues that limit their self-development. Learning beyond content, developing skills and attitudes is possible when education is based on collaboration among peers learn from each other. The pedagogical approaches presented by Paulo Freire are the base for the four step methodology proposed in the Curriculum Guide. Throughout every session participant share experiences, learn and understand new content and ventures how her life could be.

Teaching and facilitation strategies include:

- Games and dynamics: Offer concrete experiences that encourage synchronicity and induces into the discussion of certain topics.

- Guided discussion: Guides the participants to share their experiences, knowledge and their points of view.

- Study strategies: Read and synthetize information presented in books, brochures, leaflets and other scientific resources.

- Case study: Participants exercise their ability to analyze and solve real life situations through solving cases similar to what they have experienced in their own lives.

- Media analysis: Participants examine the contents and messages presented in newspapers, advertisements, radio etc.

- Safe spaces in community maps: Participants draw maps of their community identifying roads they can share with other girls, marking safe places and unsafe places within the community, and analyzing the difference in mobilization between girls and boys.

A four step methodology that draws from participants' experience and prior knowledge, invites participants to learn and turn new information into attitudes towards self-respect and leadership.

1. Welcome to our safe space: Mentors and participants greet, take attendance, talk about relevant events in the community or other relevant issues participants want to comment on.

2. Topic introduction: Through an activity that draws on current life experience, the mentor induces the participants into the topic, considering how it is relevant to their lives.

3. Definition and comprehension: Different resources are used to strengthen participant's comprehension of key concepts for each topic.

4. Application in daily life: Participants apply what they have learned into their own lives, making significant decisions and developing attitudes.

\section{USING THIS CURRICULUM GUIDE}

To ensure community mentors are able to facilitate and adapt sessions they must understand the objective of each, key concepts and necessary materials. These are detailed at the beginning of each session by specifying:

- Session number and name

- Facilitation time

- $\quad$ Participants expected outcomes

- Key concepts

- $\quad$ Required materials

\section{Text Cues}

Words in italics

Phrases, words, or questions written in italics suggest what can be said by mentors to participants.

\section{Example:}

Ask the participants:

Which skills stand out from the girl in the story?

\section{Bold words}

The words in bold letters describe expected answers to open questions or key words that indicate participants' comprehension.

\section{Example:}

A skill can be to decide what she wants to do.

\section{Teaching Tip Box:}

Teaching Tip
Provides practical advice that
improves facilitation.

\section{Warning}

It warns when it is necessary to prepare something prior to the next session.

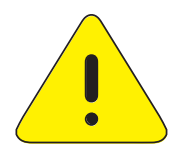

\section{Materials}




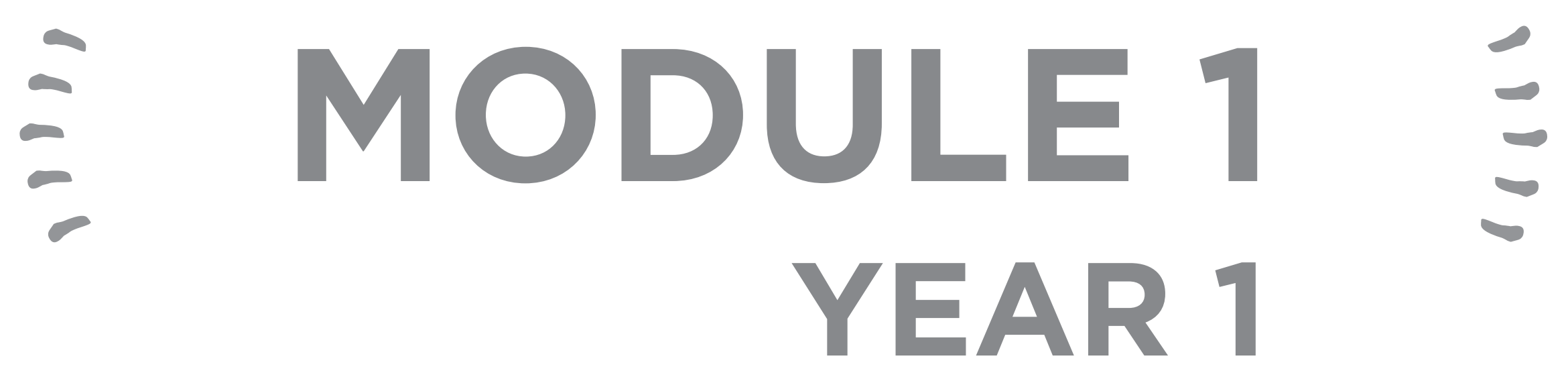




\section{MODULE 1 YEAR 1}

The first module introduces participants into the program and key issues such as safe spaces, self-esteem, and human rights.

\section{Group ages 8 to 12}

1.1 Our safe space: getting along with other girls

$\mathbf{1 . 2}$ Nutrition and the needs of a girls, adolescent girls and women

$\mathbf{1 . 3} \quad \mathrm{I}$ know and love myself

$\mathbf{1 . 4}$ I am valuable for who I am

$\mathbf{1 . 5}$ I have rights that protect me

\section{Group ages 13 to 17}

1.1 Our safe space: getting along with women

$\mathbf{1 . 2}$ Nutrition and a woman's needs

$\mathbf{1 . 3} \quad \mathrm{l}$ know and value myself

$\mathbf{1 . 4}$ I am valuable for who I am

$\mathbf{1 . 5}$ Human rights value my self-esteem 


\section{1) Our safe space: getting along with other girls}

OBJECTIVES
By the end of this session, participants
will have:
- Met their group mates.
- Visited the safe space.
- Decided how they will act towards
each other in the safe space.
- Recognized that all girls in the
community are welcomed in Girls
Creating Opportunities for a Brighter
Tomorrow
- Established a plan to get safely to
the safe space.
- Identified safe spaces in their
community.

- Community map
titled Girls Creating
Opportunities for a
Brighter Tomorrow: Our
Safe Space
- Flipchart titled: Girls
learn and care for each
other in the safe space
- Passport p/participant
- Worksheet p/participant
- Markers
- Crayons to draw/
Worksheet "Changes
in my life after 'Girls
Creating Opportunities
for a Brighter Tomorrow'

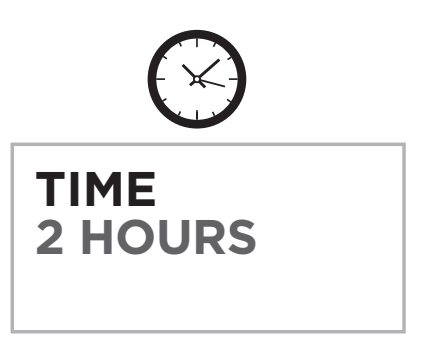
time where adolescent girls get together in a secure way, in order to learn, share and create a network of friends that will support them.

Coexistence (getting along): Relationship between people based on respect towards others and themselves. It fosters friendship in the group. 


\section{Welcame}

Welcome the participants and introduce yourself. Share your name, where you live, and what's your role in the Girls Creating Opportunities for a Brighter Tomorrow program. Tell them how excited you are to work with them. Draw on the map the path you took to reach the safe space.

Invite each participant to introduce herself in the same way and draw on the map the path she took to reach the safe space.

\section{Teaching Tip}

If you have a difficult time getting the girls to volunteer to participate on their own, play the 'hot potato' game to see who will be next.

The group sits down in a circle and the players toss an object among each other while you clap. When you stop clapping, whoever is holding the object should present herself.

\section{Topic introduction}

Organize the participants in groups according to the road they used to get to the safe space.

Ask the following questions and have them discuss the answers in their groups:

\section{What things do you like from the route? \\ What are the dangers in the route? \\ Which places in the route are safe?}

Where can all the girls in the group meet to come together to the safe space?

Ask one girl from each group to point to the place on the map where they will meet.
Invite the girls to come together in a circle and ask them to comment on:

When and how have you seen a woman help another woman?

Why is it important to know the other girls who are participating in Girls Creating Opportunities for a Brighter Tomorrow?

\section{Theory and definition}

Have participants form a circle and explain they will get to know new friends by following instructions. They must strive to meet as many girls as possible.

1. Wave at five girls that you don't know and ask for their names.

2. Shake hands with five girls and ask for their names.

3. Touch toes with five girls and ask for their names.

4. Hug five girls and ask for their names.

Ask the participants:

How do you feel about meeting new girls?

How does it feel to hug and talk them?

Would you like to get to know them more?

\section{Tell the participants:}

Every one of us brings something special to our group and we are all welcome. It is important that our group is a space for us to dream. make mistakes, learn and achieve our goals.

Place a clean flipchart titled: "Girls learn and care for each other in the safe space" next to the community map. Ask participants to brainstorm ideas about how they would like to be treated in this safe space and write the answers on the flipchart.

\section{Then say to the participants:}

Now we have our safe space and the ways we can coexist here. The safe space is a place where we meet with other girls who will become our friends. Here we can: feel free and not be afraid to talk, feel confident to share and talk about our lives, learn from our mistakes, and ask whenever we don't know something. In this safe space we will have new opportunities, experiences that 
might scare or amaze us. The weekly meetings will be for us to work through different topics, play games and learn some crafts.

Raise your hand if you feel part of the safe space and will come every week!

\section{Everyone should raise their hand. Repeat until all the girls say they are}

participants in the program and they are committed to come to the sessions.

\section{Application in daily life}

Hand out a copy of the passport to participants and let them write their name and draw their face in the space for the photo.

Say to the participants:

There is a passport for each one of you and it's only for you. It represents that you belong to Girls Creating Opportunities for a Brighter Tomorrow. In it you will keep track of your attendance at our meetings and you will make a lining to protect it. Do not lose it, take care of it.

Once they have finished working on their passport, give them the worksheet "Achievements in my life". Ask them to draw which achievements they hope to make by participating in Girls Creating Opportunities for a Brighter

Tomorrow. Let some of the girls share their drawings. 
'GIRLS CREATING OPPORTUNITIES FOR A BRIGHTER TOMORROW' PROGRAM

INTEGRATED CURRICULUM GUIDE

Achievements in My Life 


\section{2) Nutrition and the needs of a girl, adolescent and a woman}

\begin{tabular}{|c|c|c|c|}
\hline $\begin{array}{l}\text { OBJECTIVES } \\
\text { By the end of this session, participants } \\
\text { will have: } \\
\text { - Thought about their nutritional } \\
\text { needs. } \\
\text { - Recognized their right to nutrition is } \\
\text { equal to all family members'. } \\
\text { - Identified strategies to improve their } \\
\text { nutrition at different times in their } \\
\text { lives. }\end{array}$ & $\begin{array}{l}\text { MATERIALS } \\
\text { - An empty bottle with a } \\
\text { picture of a local food } \\
\text { product (corn, banana, } \\
\text { potato...) } \\
\text { - Drawings of eight } \\
\text { members of one family } \\
\text { - Drawings or images of } \\
\text { girls and women with } \\
\text { malnutrition } \\
\text { - A paper heart for each } \\
\text { girl } \\
\text { - Flip chart and markers }\end{array}$ & $\begin{array}{l}\text { TIME } \\
2 \text { HOURS }\end{array}$ & $\begin{array}{l}\text { KEY CONCEPTS } \\
\text { A woman's body changes a lot } \\
\text { according to what activities she } \\
\text { does, her age and how she cares } \\
\text { for herself. When she is a little } \\
\text { girl, her growth and development } \\
\text { depend on what food she eats. } \\
\text { When her menstruation begins, } \\
\text { she starts to have other special } \\
\text { needs because of the blood loss } \\
\text { and her physical development. } \\
\text { When she is pregnant she needs a } \\
\text { lot of vitamins, minerals, iron and } \\
\text { folic acid. After the breastfeeding } \\
\text { period, when her body feeds her } \\
\text { child, she also has to receive all } \\
\text { nutrients and iron. When a woman } \\
\text { is elderly, she needs special } \\
\text { nutrients to strengthen her bones } \\
\text { and body. }\end{array}$ \\
\hline
\end{tabular}




\section{Welcame}

Welcome the participants and take attendance. Tell the participants that today they are going to play and they need to have eaten well. Ask them to share what they have eaten or how many times they have eaten throughout the day so far.

\section{Topic introduction}

Ask participants to imagine that they are part of an 8 member family that has only one piece of corn to eat. Ask them to form eight groups and give each group a picture of one member of the family. In their groups, they must write why their assigned family member deserves to eat the only available piece of corn. Give each group half a sheet of the flipchart with the following sentence written on it and ask them to fill in the blanks in order to present the member they were assigned.

I am: and I have the right to eat the piece of

corn, because:

Ask participants to gather around and put the empty bottle with a picture of corn on the top in the center. Spin the bottle and when it stops, ask the group the bottle is pointing at, to share what they wrote on their flipchart. When all of the groups are done sharing their answers, ask:

\section{Who needs food?}

Which group convinced us that their member should have the right to get food?

How is food distributed amongst family members in this community?

What food is left for the girls?

\footnotetext{
Teaching Tip

If the bottle points to the same group twice, move to the next group

so no group is repeated and all groups have a chance to present.

You can wrap the bottle with corn husks so it resembles a whole corn.

The bottle will spin better on a smooth surface.
}

Put the pictures of the family members in order according to how food is distributed in homes in the community. Put the person who starts eating first, and the last person to get food at the end.

How does this situation affect girls?

When they are the last to eat; they get less food and the less nutritious food.

How does this situation affect girls?

It causes tiredness, malnutrition, lack of vitamins and problems for working and studying. They feel less important and less appreciated because they don't get the same food as the rest of the family members. Also, not eating makes it more difficult for them to study and keep their grades up at school.

This makes them feel less capable than boys. They get sick more often.

\section{Theory and definition}

Show the participants pictures of girls and women with malnutrition and let them see the pictures. Ask them to brainstorm signs of malnutrition that they see. Write down their answers on the flipchart.

You can ask them:

What changes or symptoms occur to the body when a person is malnourished?

Weakness, fatigue and weariness

Pale skin and gums

Less hair, colorless hair

Skin and mouth sores

Tongue pain

Excessively thin

Bloated stomach

Frequent illness and diarrhea

Swollen feet, face and hands 


\section{Application in daily life}

Give each girl a paper heart. Ask them to write their name and one thing that she likes to do and makes her heart feel happy.

S Ask for each one of them to present her heart and say:

"I have the need and right to eat well because when my body is well fed and healthy I like to:

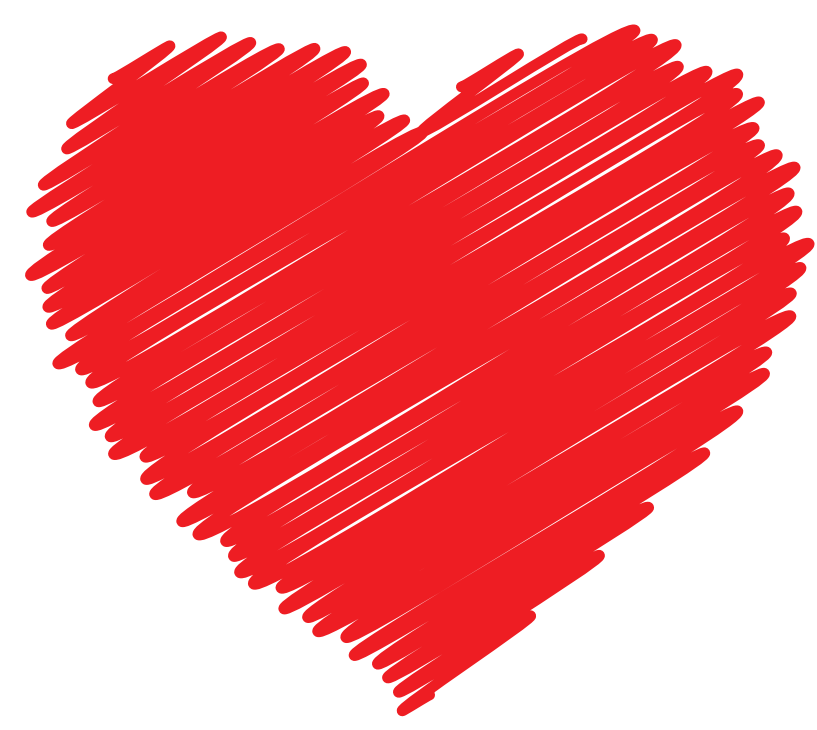




\section{3) I know and love myself}

\begin{tabular}{|c|c|c|c|}
\hline $\begin{array}{l}\text { OBJECTIVES } \\
\text { By the end of this session, participants } \\
\text { will have: } \\
\text { - Identified personal traits that make } \\
\text { them unique. } \\
\text { - Named their strengths and strengths } \\
\text { of their fellow participants. } \\
\text { - Recognized that belonging to groups } \\
\text { empowers them. }\end{array}$ & $\begin{array}{l}\text { MATERIALS } \\
\text { - Markers } \\
\text { - Flipcharts } \\
\text { - Recycling material to } \\
\text { make awards } \\
\text { - Worksheet } \\
\text { - Crayons }\end{array}$ & $\begin{array}{l}\text { TIME } \\
2 \text { HOURS }\end{array}$ & $\begin{array}{l}\text { KEY CONCEPTS } \\
\text { Identity: Self-awareness } \\
\text { of a person's features and } \\
\text { characteristics that define and } \\
\text { make them different from others. } \\
\text { Identity can be personal or } \\
\text { collective. } \\
\text { Belonging: The feeling you have } \\
\text { when you are part of a group, } \\
\text { because you share traits with } \\
\text { its' members and as a group are } \\
\text { different from other groups. } \\
\text { Strength: traits a person has that } \\
\text { will help her overcome challenges } \\
\text { and achieve goals in life. No one } \\
\text { can take away a person's strengths. }\end{array}$ \\
\hline
\end{tabular}




\section{Welcame}

Welcome the participants and take attendance. Share something you like about each participant. Pay special attention to the girls who participate less or are more reserved.

\section{Topic introduction}

Irma, Elbia, and Olga are good friends and they go to school together. This morning, Olga and Elbia were surprised because Irma didn't show up. She is always on time and eager to study. They knew that without Irma they were not going to laugh as much and the day was going to be boring. This first class was Social Studies and Olga who is very disciplined thought she would help Irma by taking notes for her. When she finished taking notes, Olga had a problem: she had two sheets of the exact same paper and she was starting to get confused between hers and Irma's. That's when Elbia, who is very organized, helped her too. She asked Olga for the copies and saved them throughout the day so they could give them to Irma organized and completed.

Meanwhile, Irma was in her house feeling extremely ill. Her mother, who was always busy taking care of all kinds of things, was making her soup and tortillas for lunch before her aunt came over to take care of her wile Irma's mother went to work. They didn't know what was wrong with Irma; she had a fever, stomachache and nausea. They knew that if she continued with the symptoms, they were going to have to take her to the clinic, which was very far away and they would need transportation.

Irma's aunt, who was very kind and knew everybody in the village, went to Mr. Juan's house and told him about her niece's situation. Mr. Juan, without hesitation, offered to take her to the Health Center in his truck, if necessary. He was a very caring man, good to have around in emergencies. They exchanged phone numbers and Irma's aunt thanked him.
The good thing is, that as the day went by, Irma felt much better and her body was recovering. She greeted Elbia and Olga with excitement when they went to visit her in the afternoon to drop off the copies they took at school. The three friends were very happy to be together again and for helping each other.

\section{Guide participants through dialogue about the story. Ask them:}

What happened to Irma?

She got sick and did not go to school for one day.

What was missed the most about Irma during her absence? The fun environment and the way she makes her friends laugh.

What strength did Irma have that helped her always make good grades? She was always on time and she was eager to study.

Put up a flipchart and ask girls to draw Irma and all the people that were worried about her and willing to help. As they do this dialogue about:

What was Irma's relationship with each person?

\section{Olga and Elbia: friends from school}

Her mother and aunt: relatives

Mr. Juan: neighbor from the village

What strengths did each character use for helping Irma?

Olga was disciplined

\section{Elbia was organized}

\section{Mother was taking care of things}

Aunt was kind and sociable

Mr. Juan was caring

What groups does Irma belong to?

School (Olga and Elbia)

Family (Aunt and Mother)

Community (Mr. Juan)

Draw a circle around Irma and the other characters to show each group and how Irma can belong to several groups that support her. 


\section{Theory and definition}

Put a blank flipchart in front of the group and say to the participants that just as Irma got sick, we all face different challenges in our lives that make our development difficult. Give each girl a crayon. They will have to pass to the flipchart and write a challenge they face. After a while, read some of the answers they wrote.

On the same flipchart write the title: STRENGTHS, have them talk about what are strengths and give some examples. Complement their answers with the

key concept emphasizing that we all have different strengths that help us overcome challenges we face.

Handout "My strengths" worksheets and ask participants to draw themselves and write 5 traits they have that make them strong.

Ask them to turn the sheet over and divide it in four parts. While they are folding the paper, tell them:

In the story, each friend has different strengths and belongs to several groups within the community. All of us here have strengths and we are also part of Girls Creating Opportunities for a Brighter Tomorrow.

Ask them to write down a group they belong to in each of the four spaces (family, school, friends, neighborhood, church, Girls Creating Opportunities for a Brighter Tomorrow, etc.) and the name of a person of that group who cares about and protects you.

\section{Application in daily life}

Ask them to team couple up, each girl will make an award for her partner recognizing her strengths using recycling material. Give them time to create the award and then have each girl give the award to her partner and share what she wrote with the rest of the participants. Write all the strengths on the flipchart to show the wealth of strengths in the Girls Creating Opportunities for a Brighter Tomorrow group.

If there is time left they can also work on the My weaknesses worksheet. 


$$
0
$$




$$
0
$$




\section{4) I am valuable for who I am}

\begin{tabular}{|c|c|c|c|}
\hline $\begin{array}{l}\text { OBJECTIVES } \\
\text { By the end of this session, participants } \\
\text { will have: } \\
\text { - Explored their feelings towards } \\
\text { themselves identifying that they are } \\
\text { valuable. } \\
\text { - Understood what self-esteem } \\
\text { is and how it can help people's } \\
\text { development. } \\
\text { - Identified situations that negatively/ } \\
\text { positively affect their self-esteem } \\
\text { and ways to take care of it. }\end{array}$ & $\begin{array}{l}\text { MATERIALS } \\
\text { - Flipchart } \\
\text { - Markers } \\
\text { - Definition of self esteem } \\
\text { - Worksheet } \\
\text { - Story "A new Rosa" } \\
\text { (Translation of My voice, } \\
\text { my dream, my world) }\end{array}$ & $\begin{array}{l}\text { TIME } \\
2 \text { HOURS }\end{array}$ & $\begin{array}{l}\text { KEY CONCEPTS } \\
\text { Self-esteem: image, perception } \\
\text { and value that people have of } \\
\text { themselves. It is the basis of } \\
\text { how someone values herself. It is } \\
\text { developed through the interaction } \\
\text { with family, friends, school, church, } \\
\text { the media and all of the messages } \\
\text { that speak of her about what she } \\
\text { is. The way a person sees and } \\
\text { values themselves can change } \\
\text { from one moment to the next and } \\
\text { throughout the person's life; it } \\
\text { affects behavior towards the self } \\
\text { and towards others. }\end{array}$ \\
\hline
\end{tabular}




\section{Welcame}

Welcome the participants and take attendance. Ask about the girls who are absent to see if any girl knows where they are and what they can do to help them attend the sessions. Take this moment to talk about how they feel about the sessions and what has changed in them since they have been participating.

\section{Topic introduction}

Tell the participants that we are going to read a story from the book My Voice, My Dream, My World. Form three groups and give each group a part of the story to read. To finish up, give each group a sheet of paper and ask them to answer the following questions:

Who is the story about?

What does the story say?

What got your attention in the story?

Give them five minutes to respond and end the activity by having each group share their answers and write them on the flipchart sheet.

Ask the participants to return to their groups to discuss about the following questions:

\section{How is Rosa's story similar to our story?}

What characteristics does Rosa have?

What characteristics do I have that make me similar to Rosa and what characteristics make me different from her?

Since when do I have these qualities?

Play the statues game. Have some volunteer as statue and others as sculptors. The sculptors will have to model one statue to represent one of Rosa's characteristics, while the rest of the group guesses which one it is. Play a few rounds and then ask the participants:

What life experiences have made you feel like Rosa?

\section{Theory and definition}

Write the word "SELF-Esteem" on the flipchart. Talk with the participants about the meaning of the two words that make up Self-esteem and what it means. Write down key words that define the concept on the flipchart. Tell the participants:

You have thought about what characteristics make you like Rosa and others that make you different. This shows how you view yourselves and how you feel about yourselves. This is self-esteem.

Read together about the concept of self-esteem, how it is developed. Dialogue with participants about experiences they've had that have positively or negatively affected their self-esteem.

Every person has self-esteem and the way we treat each other affects the self-esteem of others. Sometimes we don't even notice but we affect our friends' self-esteem.

When have I seen someone negatively affecting a friend's self-esteem?

When people gossip; when people talk mean to someone; when people do not accept someone to a group; when people do not allow someone to study.

What happens when she feels bad about herself?

She cannot do the things she wants to do; she is scared and will not try to use her skills. She does not interact with other people; she can become angry and frustrated.

How can you help improve the self-esteem of other women in the community?

Accepting them in the group; having good communication; respecting them; value the women who participate; not gossiping; teamwork; sharing difficulties and looking for solutions together; telling them about their strengths and good qualities.

\section{Application in daily life}

Ask the participants to take the worksheet "What do I value about myself?" and write in each flower petal something that they really like about themselves, and in the center write how they feel when they think about these kind of things. 


\section{A new Rose}

\section{By Rosa Lacán Petzey}

"I was a working child. I couldn't go to school. When I turned 8, I started working at a house, babysitting other children. I also carried bread for different stores. My father drank a lot and that is why I had to keep on working. I did laundry, made tortillas, sold bread, and made cakes for eight years. At that time, I decided to start school, so I was working and studying and in three years I was able to finish sixth grade. I finally had a diploma.

I looked for another job at a hotel. I didn't like it that much because there was a lot of discrimination. I put up with it for six months. One day, I heard a radio announcement on the Opening Opportunities program. A person I knew was encouraging me to apply and send my paperwork, and I said, "I can't. I don't know anything. I am a silly person that can't do a lot of things and I have no schooling". I sent out my paperwork anyways. Then they called me for an interview, and a few days later, they said yes... I was so happy!

When I started the training process I couldn't express myself, I was very shy. I couldn't speak English, I couldn't write well, I was discriminating myself and I was afraid of going outside my house. But now, after the Opening Opportunities workshops, my life has changed. I finished 9th grade, and I am different. I can express freely, I am not shy anymore, and I know how to value myself, to love and respect myself, and make good decisions. I have goals, I respect other people and I encourage them to be unique, valuable and to keep on moving forward. 


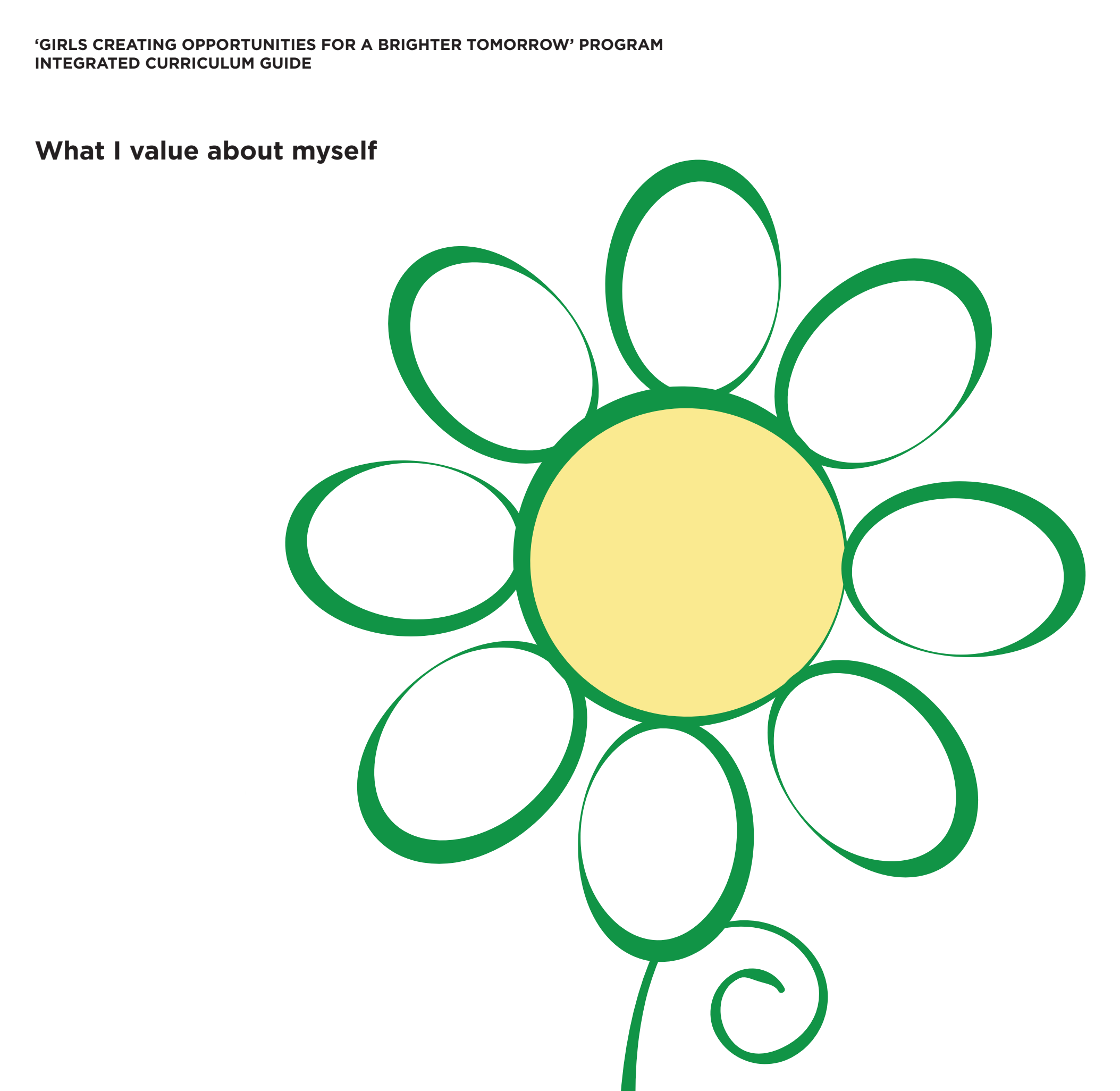




\section{5) I have rights that protect me}

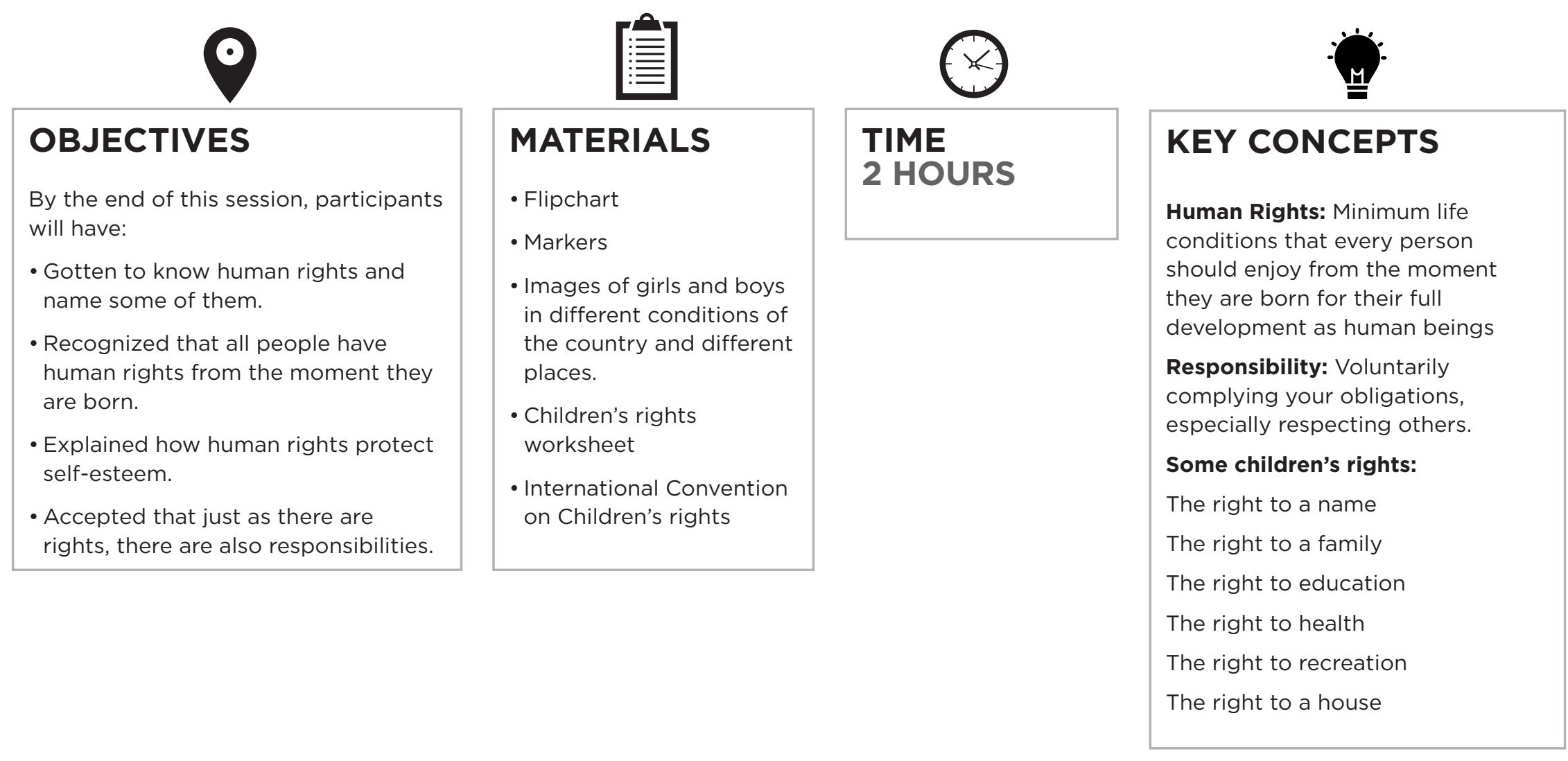




\section{Welcame}

Welcome the participants and take attendance. Share that today they are going to learn about the living conditions that the whole world has agreed that every person on the planet must have, especially for girls and boys to be happy and grow.

\section{Topic introduction}

Show the girls an image of boys and girls who live in different places and conditions (include those who live in poverty and those who do not). Allow them to take a look at the pictures and brainstorm about things children need to achieve their full development. Write down their answers on the flipchart.

\section{Ask them identify in what pictures children do not have all they need and} have a group dialogue about:

How do you think these children's self-esteem is?

Situations that difference you from them?

Situations you have in common with them?

After that, show them an image of girls and boys that live in good conditions that meet their needs and lead the dialogue concerning:

How do their life conditions help them fully develop?

How do you think these children's self-esteem is?

What issues help their self-esteem?

Situations that difference you from them?

Situations you have in common with them?

In what ways are all children alike?

Explain by saying to the participants:

In the world, children as well as adolescents, adults and the elderly, share human dignity. This means that we are all important and valuable and we are worth being alive. But, at the same time, people live in very different ways: some have a lot and get everything they need and others don't have what they need. Looking at the pictures and thinking about your own lives, you are going to form groups of four girls and you are going to make a list of the most important things every child must have in order to live happy and grow well.
Divide them into groups so they can work with girls from different ages and help one another. Then allow time for the groups to present their lists.

\section{Theory and definition \\ 5 Comment to the group:}

More than 50 years ago, world leaders got together to make a list, just like the one you just did, about the things every person must have in order to be happy and grow. They called the list: The Human Rights.

Give each girl the "Children's Rights" worksheet. Read together the rights while solving any doubts along the way and underlining with them the key words in each right.

For each right, ask the participants to give an example of how the right is being respected or not in the community and why it is important for their self-esteem.

While reading, review and write on the flipchart the rights included in the participant's lists. Then ask:

What does it mean that the rights are for every child? Who do they protect?

What rights are met in the community?

Which are the rights that are the least met for the girls in the community?

Why does meeting our rights help our self-esteem?

Reflect with them about how each right implies a responsibility. They are responsible for respecting their rights and their group mates' rights. How can they support the fulfillment of every girl's rights? What responsibilities do they have? 


\section{Application in daily life}

Divide the participants into five groups and give each group a flipchart with one of the following rights:

- GROUP 1: Every girl and boy has the right to a first name and last name.

- GROUP 2: Every girl and boy has the right to a family that cares about and loves them.

- $\quad$ GROUP 3: Every girl and boy has the right to a decent home to live in.

- $\quad$ GROUP 4: Every girl and boy has the right to go to school and learn interesting and important things for their lives.

- GROUP 5: Every girl and boy has the right to receive medical attention and care for their health.

At the bottoms of each flipchart write:

- GROUP 1: When girls have a name, we feel...

- GROUP 2: When girls have a family, we feel..

- GROUP 3: When girls have a home, we feel...

- GROUP 4: When girls go to school to learn, we can...

- $\quad$ GROUP 5: When girls are healthy, we like to...

Ask the groups to draw a picture of how this right is fulfilled in the lives of girls and boys in the community. Then, they have to complete the sentence at the bottom of the flipchart. 


\section{1) Our safe space: Getting along with other women}

OBJECTIVES
By the end of this session, participants
will have:
- Gotten to know their group mates.
- Visited the safe space.
- Decided how participants will treat
- Recognized that all adolescent girls
in the community are welcome in
Girls Creating Opportunities for a
Brighter Tomorrow.
- Established a plan to get safely to
the safe space.
- Identified safe spaces in their
community.
- Talked about the risks for adolescent
girls in the community.

MATERIALS
- Map of the community
- Markers
- General list of topics that
will be worked on in the
program
- Flipchart
- Worksheet

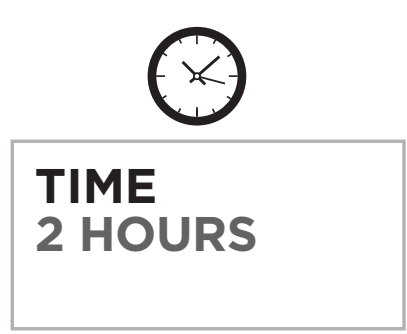

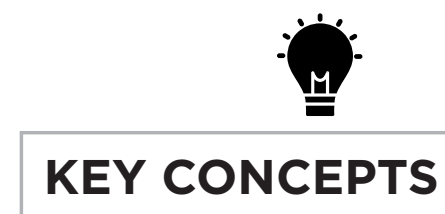

Safe space: It is the place and time where adolescent girls get together in a protected way, in order to learn, share and create a network of friends that will support them.

Coexistence (getting along):

Relationship between people based on respect towards others and themselves. It fosters friendship in the group. 


\section{Welcame}

Welcome the participants and introduce yourself. Share your name, where you live, and what's your role in the program. Tell them how excited you are to work with them. Draw on the map the road you took to reach the safe space.

Invite each participant to introduce herself in the same way and draw the road she took to reach the safe space on the map.

\section{Topic introduction}

Organize the participants in groups according to the road they followed to get to the safe space. Have them discuss the following questions in their groups:

What things do you like from the road?

What are the dangers in the road?

What risks are there when going on the road?

Which places in the path are safe spaces?

What places on the path are you going to meet up with each other to come to the safe space?

Ask one girl from each group to mark the spot where they will meet on the map. And then gather all together to discuss about:

In what moments do we need help from other women?

When and how have you seen a woman help another woman in the community?

Why is it important to know the other women

that participant in Girls Creating Opportunities for a Brighter Tomorrow?

\section{Theory and definition}

Ask participants to stand up and form a circle. Explain that this is an activity that will help to get to know new friends. They must follow instructions and try to meet as many girls as possible.
1.

2.

3.

4.

Wave at five girls that you don't know and ask for their names. Shake hands with five girls and ask for their names. Touch toes with five girls and ask for their names.

\section{Hug five girls and ask for their names.}

\section{Ask the participants:}

How do you feel about meeting new friends?

How does it feel to hug and talk them?

Would you like to get to know them more?

\section{Tell the participants:}

Every one of us brings something special to our group and we are all welcome. It is important that our group is a space for us to dream, make mistakes, learn and achieve our goals.

Place a flipchart titled: "Adolescent girls learn and care for each other in the safe space" next to the map. Ask the participants to think about how they would like to be treated in this safe space and write the answers on the flipchart.

\section{Then say to the participants:}

Now we have our safe space and the ways we can coexist here. The safe space is a place where we meet with other girls who will become our friends. Here we can: feel free and not be afraid to talk, feel confident to share and talk about our lives, learn from our mistakes, and ask whenever we don't know something. In this safe space we will have new opportunities, experiences that might scare or amaze us. The weekly meetings will be for us to work through different topics, play games and learn some crafts.

Raise your hand if you feel part of the safe space and will come every week!

Everyone should raise her hand. Insist until all the girls say they are part of Girls Creating Opportunities for a Brighter Tomorrow and they are committed to come to the sessions.

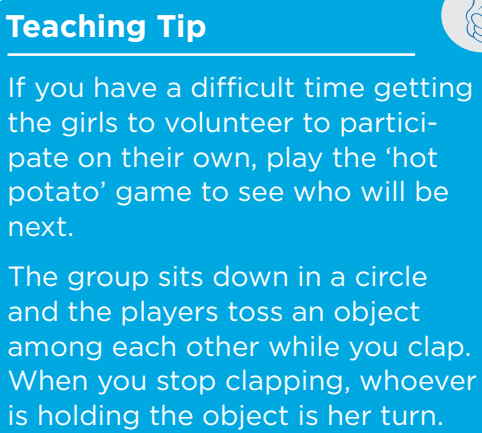

If you have a difficult time getting the girls to volunteer to participate on their own, play the 'hot potato' game to see who will be next.

The group sits down in a circle and the players toss an object among each other while you clap. When you stop clapping, whoever is holding the object is her turn. 


\section{Application in daily life}

Hand out a copy of the passport to participants and let them write their name and draw their face in the space for the photo.

\section{Say to the participants:}

There is a passport for each one of you, and it's only for you. It represents that you belong to Girls Creating Opportunities for a Brighter Tomorrow. In it you will keep track of your attendance at our meetings and you will make a lining to protect it. Do not lose it, take care of it.

Show them a general list of topics that will be worked on in the program and have them read the list individually. Give them the worksheet "Achievements in my life". Ask them to draw which achievements they hope to make by participating in Girls Creating Opportunities for a Brighter Tomorrow. Let some of the girls share their drawings.

Ask that the participants work on the sheet "What can change in my life" at home. 
'GIRLS CREATING OPPORTUNITIES FOR A BRIGHTER TOMORROW' PROGRAM

INTEGRATED CURRICULUM GUIDE

Achievements in my life
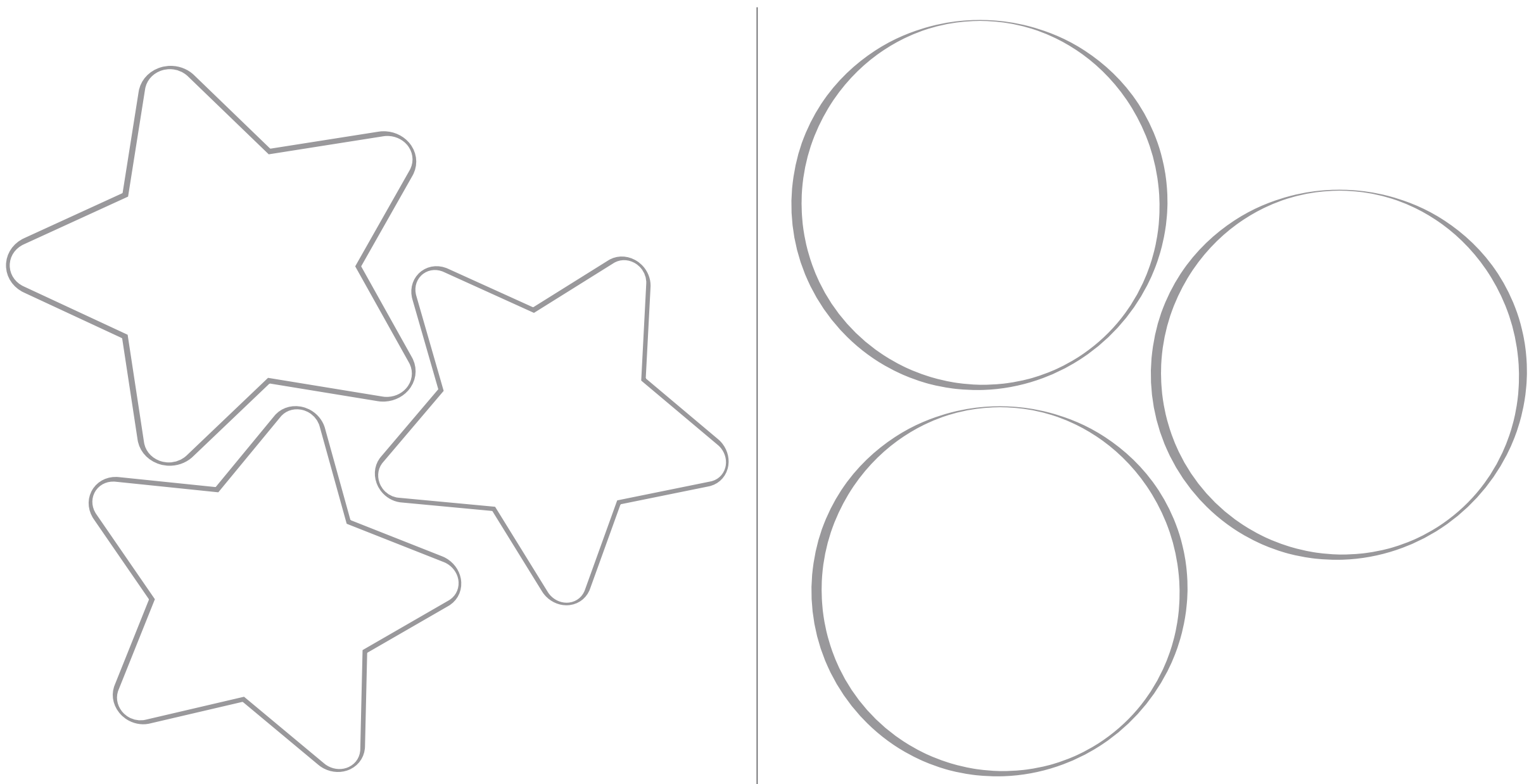

33 
'GIRLS CREATING OPPORTUNITIES FOR A BRIGHTER TOMORROW' PROGRAM INTEGRATED CURRICULUM GUIDE

What can change in my life?

My life today

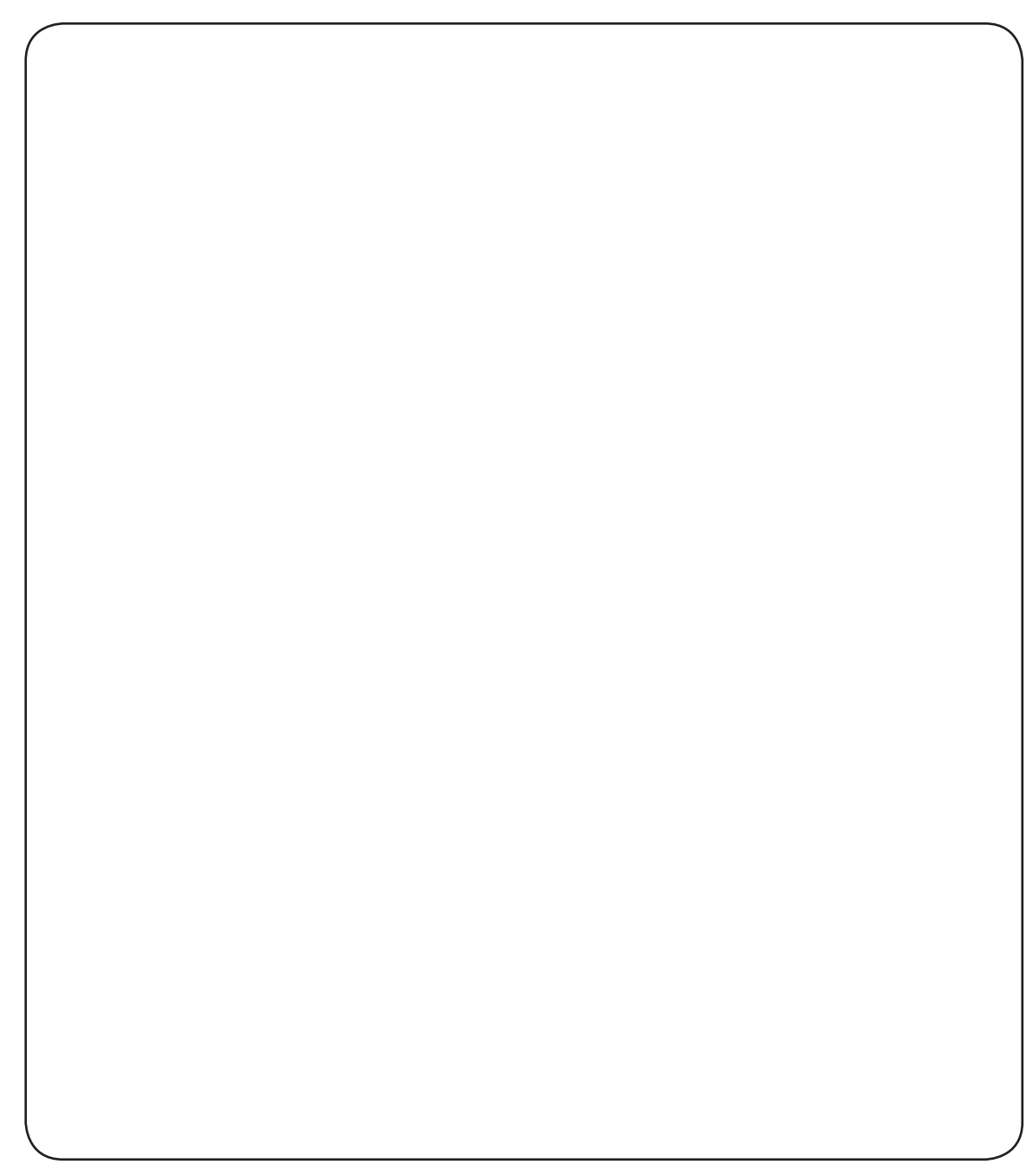

My life after Girls Creating Opportunities for a Brighter Tomorrow 


\section{2) Nutrition and a woman's needs}

\begin{tabular}{|c|c|c|c|}
\hline $\begin{array}{l}\text { OBJECTIVES } \\
\text { By the end of this session, participants } \\
\text { will have: } \\
\text { - Gotten to know women's nutritional } \\
\text { needs. } \\
\text { - Identified strategies to improve } \\
\text { women's nutrition at different points } \\
\text { in their lives. } \\
\text { - Reflected about the effect of } \\
\text { nutrition on a woman's development } \\
\text { compared to the rest of the family. } \\
\text { - Recognized their right to nutrition } \\
\text { equal to that of their family } \\
\text { members. }\end{array}$ & $\begin{array}{l}\text { MATERIALS } \\
\text { - An empty bottle with a } \\
\text { picture of a local food } \\
\text { (corn, banana, potato...) } \\
\text { - Drawings of eight } \\
\text { members of one family } \\
\text { - Drawings or images of } \\
\text { girls and women with } \\
\text { malnutrition. } \\
\text { - Flip charts } \\
\text { - Markers }\end{array}$ & $\begin{array}{l}\text { TIME } \\
2 \text { HOURS }\end{array}$ & $\begin{array}{l}\text { KEY CONCEPTS } \\
\text { A woman's body changes a lot } \\
\text { according to what activities she } \\
\text { does, her age and how she cares } \\
\text { for herself. When she is a little } \\
\text { girl, her growth and development } \\
\text { depend on what food she gets. } \\
\text { When her menstruation begins, } \\
\text { she starts to have other special } \\
\text { needs because of the blood loss } \\
\text { and her physical development. } \\
\text { When she is pregnant she needs a } \\
\text { lot of vitamins, minerals, iron and } \\
\text { folic acid. After the breastfeeding } \\
\text { period, when her body feeds her } \\
\text { child she also has to receive all } \\
\text { nutrients and iron. When a woman } \\
\text { is elderly, she needs special } \\
\text { nutrients to strengthen her bones } \\
\text { and body. }\end{array}$ \\
\hline
\end{tabular}




\section{Welcame}

Welcome the participants and take attendance. Tell the participants that today they are going to play and they need to have eaten well. Ask them to share what they have eaten or how many times they've eaten throughout the day so far.

\section{Topic introduction}

Ask them to form eight groups and give each group a picture of one member of the family. Tell the participants to imagine that they are in a family of eight that does not have much to each. Each group should think about the reasons that the family member they have should eat what food is available. Give them 10 minutes to discuss.

Then ask the participants to form a circle and put the empty bottle with a picture of corn on the top in the center. Spin the bottle and when it stops, ask the group the bottle is pointing at, to share why the family member that they had should eat the corn.

\section{When finished ask all the groups:}

How is food distributed in the houses of this community?

Put the pictures of the family members in order according to how food is distributed in homes in the community. Put the person who starts eating first, and the last person to get food at the end.

How does this situation affect girls, adolescents and women in the community?

They are the last to eat; they get less food and the less nutritious food.

How does it affect the health and self-esteem of girls, adolescents and women in the community?

It causes tiredness, malnutrition, lack of vitamins and problems for working and studying. They feel less important and less appreciated because they don't get the same food as the rest of the family members. Also, not eating makes it more difficult for them to study and keep their grades up at school. This makes them feel less capable than boys. They get sick more often.

\section{Theory and definition}

Show the participants pictures of girls and women with malnutrition and let them see the pictures. Ask them to brainstorm signs of malnutrition that they see. Write down their answers on the flipchart. You can ask them:

What changes or symptoms occur to the body when a person is malnourished?

Weakness, fatigue and weariness

Pale skin and gums

Less hair, colorless hair

Skin and mouth sores

Tongue pain

Excessively thin

Bloated stomach

Frequent illness and diarrhea

Swollen feet, face and hands

At which moments in a woman's life does she have special nutritional needs to be healthy?

\section{Menstruation, pregnancy, when nursing a child, always}

What foods are available in our community that have a lot of iron, protein and vitamins that we should eat most of our lives?

Greens, beans, vegetables, fruits, meat, chicken, eggs, milk, salt

\section{Application in daily life}

Form three groups. Give each group a flipchart and markers. Ask each group to draw a complete and nutritious meal for the girls, adolescent girls and women in the community. The meal can be: inexpensive, with different types of tasty and nutritious food found in the community. They should create a sentence that convinces everyone why a women are entitled nutritious meals at every age.

Allow 10 minutes for each group to work and then have the groups present their menu and put it up for the rest of the group to see. While presenting, applaud and congratulate each group. 


\section{3) I know and value myself}

\begin{tabular}{|c|c|c|c|}
\hline $\begin{array}{l}\text { OBJECTIVES } \\
\text { By the end of this session, participants } \\
\text { will have: } \\
\text { - Identified that they are part of } \\
\text { various groups that they interact } \\
\text { with and contribute to. } \\
\text { - Stated their strengths as well as the } \\
\text { strengths of their fellow participants. } \\
\text { - Recognized that belonging to certain } \\
\text { groups empowers them. }\end{array}$ & $\begin{array}{l}\text { MATERIALS } \\
\text { - Markers } \\
\text { - Flipcharts } \\
\text { - Worksheet } \\
\text { - White paper } \\
\text { - Recycling materials for } \\
\text { making flowers }\end{array}$ & $\begin{array}{l}\text { TIME } \\
2 \text { HOURS }\end{array}$ & $\begin{array}{l}\text { KEY CONCEPTS } \\
\text { Identity: Self-awareness of a } \\
\text { person's features and traits that } \\
\text { define and make them different } \\
\text { from others. The identity can be } \\
\text { personal or collective. } \\
\text { Belonging: The feeling you have } \\
\text { when you are part of a group, } \\
\text { because you share something in } \\
\text { common with its members and } \\
\text { you, as a group, differentiate } \\
\text { yourselves from other groups. } \\
\text { Strength: Features, qualities, or } \\
\text { innate characteristics of a person } \\
\text { that allow them to overcome the } \\
\text { challenges and achieve goals in life. } \\
\text { No one can take away a person's } \\
\text { strengths. } \\
\text { Weaknesses: Features, qualities } \\
\text { and characteristics of a person that } \\
\text { have not been developed to their } \\
\text { full potential. }\end{array}$ \\
\hline
\end{tabular}




\section{Welcame}

Welcome the participants and take attendance. Share something you like about them or a special skill they have with every participant. Pay special attention to the girls who participate less or are more reserved.

\section{Topic introduction}

Tell the group the following story:

Irma, Elbia, and Olga are good friends and they go to school together. This morning, Olga and Elbia were surprised because Irma didn't go to school. She is always on time and eager to study. They knew that without Irma they were not going to laugh as much and the day was going to be boring. This first class was Social Studies and Olga, who was disciplined, thought she would help Irma by taking notes for her. When she finished taking notes, Olga had a problem: she had two sheets of the exact same paper and she was starting to get confused between hers and Irma's. That's when Elbia, who is very organized, helped her too. She asked Olga for the copies and saved them throughout the day so they could give them to Irma organized and completed.

Meanwhile, Irma was in her house feeling very sick. Her mother, always taking care of things, was making her soup and tortillas in a hurry because Irma's aunt was going to come over at midday so her mother could go to work at the diner where she's the cook. They didn't know what was wrong with Irma. Irma had a fever, stomachache and nausea. They knew that if she continued with the symptoms, they were going to have to take her to the clinic, which is very far away and they would need transportation.

Irma's aunt, who was kind and knew everybody in the village went to Mr. Juan's house and told him about her niece's situation. Mr. Juan, without hesitation, offered to take her to the Health Center in his truck, if necessary. He was very caring. They exchanged phone numbers and Irma's aunt thanked him.
The good thing is, that as the day went by, Irma felt much better and her body was recovering. She greeted Elbia and Olga with excitement when they went to visit her in the afternoon to drop off the copies they took at school. The three friends were very happy to be together again and for helping each other

Together with the participants, reflect on the story and the way people treat each other. Ask them:

What happened to Irma?

\section{She got sick and did not go to school for one day}

What was missed the most about Irma during her absence?

The fun environment and the way she makes her friends laugh.

What strength did Irma have that helped her always make good grades?

\section{She was always on time and she was eager to study.}

Which people were worried about her during the day?

\section{Olga, Don Juan, Elbia, mom.}

Ask participants to draw these people around Irma, and continue motivating dialogue through the following questions:

What was Irma's relationship with each person?

\section{Olga and Elbia: friends from school}

Her mother and aunt: relatives

Mr. Juan: neighbor from the village

What strengths did each character use for helping Irma?

\section{Olga: disciplined}

Elbia: organized

Mother: always takes care of things

Aunt: kind and sociable

Mr. Juan: Very caring

What groups does Irma belong to?

School (Olga and Elbia)

Family (Aunt and Mother)

Community (Mr. Juan) 
Draw a circle around Irma and the other characters to show each group and how Irma can belong to several groups that support her.

How did it help Irma to be part of so many groups?

\section{Theory and definition}

Say to the participants that every person is different because of their strengths and weaknesses. A strength is a positive trait and nobody can take it away. A weakness is a characteristic that is difficult for us or we feel like we can't do very well. The more we share our strengths with the groups we belong to, the more the group will live and grow. Just like in the story, Girls Creating Opportunities for a Brighter Tomorrow has strengths and weaknesses that we are going to share.

Hand each participant a sheet of paper and tell them to couple up with a friend. It is important that everyone has a partner. Ask them to write three strengths of their friend on the paper and to make a flower out of the paper and recycled material to give to their friend. After finishing the flower for your friend, come back to the circle and everyone will present their friend and share with the group what strengths she has and give her the flower you made.

While they are presenting, write all the strengths on a flipchart so that they can see the richness of the Girls Creating Opportunities for a Brighter Tomorrow group in their community.

Ask them:

What do you see as the principal strengths of the group that we belong to? What can we bring to our community as women with these strengths?

What changes can we make in our community with our strengths?

Everyone comes up and puts their flower on a large flower that says: "We are Girls Creating Opportunities for a Brighter Tomorrow."

\section{Application in daily life} Weaknesses" worksheet. Invite the participants to write their strengths in the petals and their weaknesses in the little bugs. 
Who am I?

My flower: my strengths and weaknesses

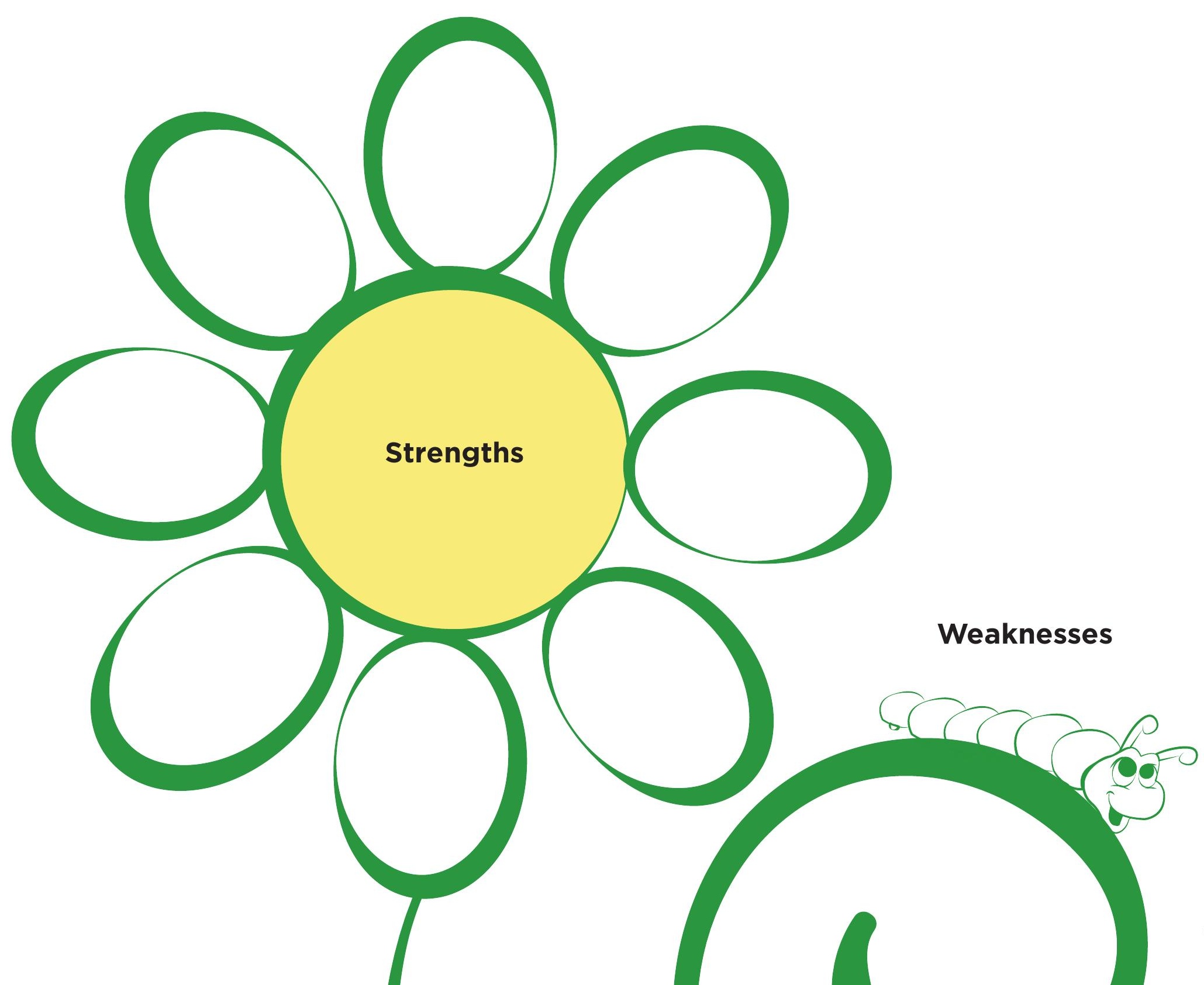




\section{4) I am valuable for who I am}

OBJECTIVES
By the end of this session, participants
will have:
- Explored their feelings towards
themselves identifying themselves as
valuable.
- Understood what self-esteem
is, and how it can help people's
development.
- Identified which situations
negatively/positively affect their self-
esteem and ways to take care of it.

MATERIALS
- A mirror
- Sheets of paper
- Pencils
- Crayons and markers
- Flipcharts
- Reused material to make
flowers
- Worksheets

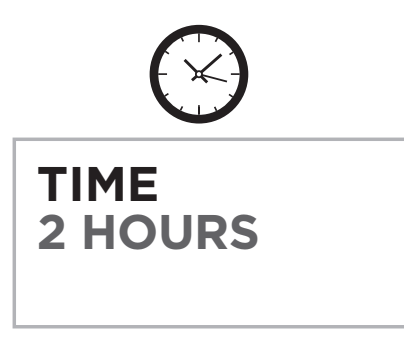
and value that people have of themselves. It is the basis of how someone values herself. It is developed through the interaction with family, friends, school, church, media and all of the messages that speak of her about what she

is. The way a person sees and values themselves can change from one moment to the next and throughout the person's life; it affects our behavior towards ourselves and others. 


\section{Welcame}

Welcome the participants and take attendance.

Ask about the girls who are absent to see if any girl knows where they are and what they can do to help them attend the sessions. Take this moment to talk about how they feel about the sessions and what has changed in them since they have been participating in Girls Creating Opportunities for a Brighter Tomorrow.

\section{Topic introduction}

Ask participants to brainstorm all the plants they know (flowers, trees, shrubs, grasses ...) and write their answers on the flipchart. Ask them to imagine they are plants and chose a plant they resemble the most. Tell them to think about their different traits: their body, the way they are, their relationships with other girls and people, their strengths and weaknesses, their ideas..

Hand each of the participants a sheet of paper and ask them to draw the plant they chose and write the traits that make her resemble her choice of plant. Ask them to form groups of three friends and share their work in their group by answering:

\section{What plant did I compare myself with?}

What traits do I have that made me to compare myself with this plant? How do I feel about having these traits?

Next, bring the groups back together and ask:

What was the most difficult part of this exercise?

What were your friend's reactions when you told them how you see yourself?

Does anyone disagree with the way their group mates described themselves? What other plant would you have given them?

What life experiences have caused you to look at yourselves like the plant you chose?

\section{Theory and definition}

Hand each participant one sheet of paper and ask them to close their eyes and picture the story you will tell them next. They all have to have at hand their paper and pencil. Tell them the following story:

"Are you dumb?" "Can't you do anything right?" A woman spoke these words to her little daughter just because she separated from her mother while walking. The mother spoke them so loud that everyone turned around to see, and the girl felt very bad and sad. The girl, with tearful eyes, returned to her mother's side. Walking past a window, she saw some mirrors and saw her own reflection. How do you think she felt? What did she see in the mirror? How did she see herself? What does she think about herself?

Think for a moment if you've ever felt like this little girl. Then, on the sheet of paper draw how you think the little girl saw herself when she looked in the mirror. You can also use words to describe her ideas and feelings about her physical appearance, her relationships with other people, her strengths and her intelligence.

Ask them to individually draw what they imagined on the paper. Continue with the story:

Suddenly, the girl falls to the ground and you help her up. You give her a loving hug and do anything you can to comfort her, listen to her and help her feel better about herself. You notice that you have many things in common with the way she sees herself and how you see yourself. Sometimes, she is very sure of herself and happy, eager to do things cheerfully and even do hard things. But, sometimes, she doesn't think she is good, she thinks she doesn't know anything and that she's weak and dumb. Without thinking, you begin telling her all of the times that someone has made you feel bad about yourself, and those other times when you do what helps you feel good about yourself.

Pass a mirror between the participants and ask them to see themselves with the mirror in silence and think about the questions you posed. On the other side of the paper, ask them to draw how they see themselves; they can also use words to describe themselves.

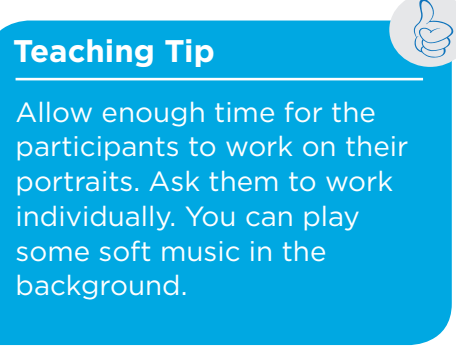


Write the word "SELF-Esteem" on the flipchart. Talk with the participants about the meaning of the two words that make up Self-esteem and what the concept means. Write down key words that define the concept on the flipchart.

\section{Tell the participants:}

Read together about the concept of self-esteem- how it is formed and what it is made up of. Reflect with the participants about experiences they've had that have positively or negatively affected their self-esteem.

Every person has self-esteem and the way we treat each other affects the self-esteem of others. Sometimes we don't even notice but we affect our friends' self-esteem.

When have I seen someone negatively affecting a friend's self-esteem?

When people gossip; when people talk mean to someone; when people do not accept someone to a group; when people do not allow someone to study.

What happens when she feels bad about herself?

She cannot do the things she wants to do; she is scared and will not try to use her skills. She does not interact with other people; she can become angry and frustrated.

How can you help improve the self-esteem of other women in the community?

Accepting them in the group; having good communication; respecting them; value the women who participate; not gossiping; teamwork; sharing difficulties and looking for solutions together; telling them about their strengths and good qualities.

\section{Application in daily life}

Hand out the "How I feel" worksheet for them to work on individually. In the circle on the left they should write something that does not make them feel good about themselves. In the arrow in the middle, write what they are going to do to take care of their feelings and change it. In the circle on the right they should write how they would like to feel about this aspect of themselves. There are six spaces, but they do not have to use all the spaces. Check that everyone has understood the exercise and give them time to work individually. While they are working, you can walk amongst them to make sure they are doing it well and answer any questions they might have. 
'GIRLS CREATING OPPORTUNITIES FOR A BRIGHTER TOMORROW' PROGRAM INTEGRATED CURRICULUM GUIDE

\section{How do I feel?}

How do I feel?
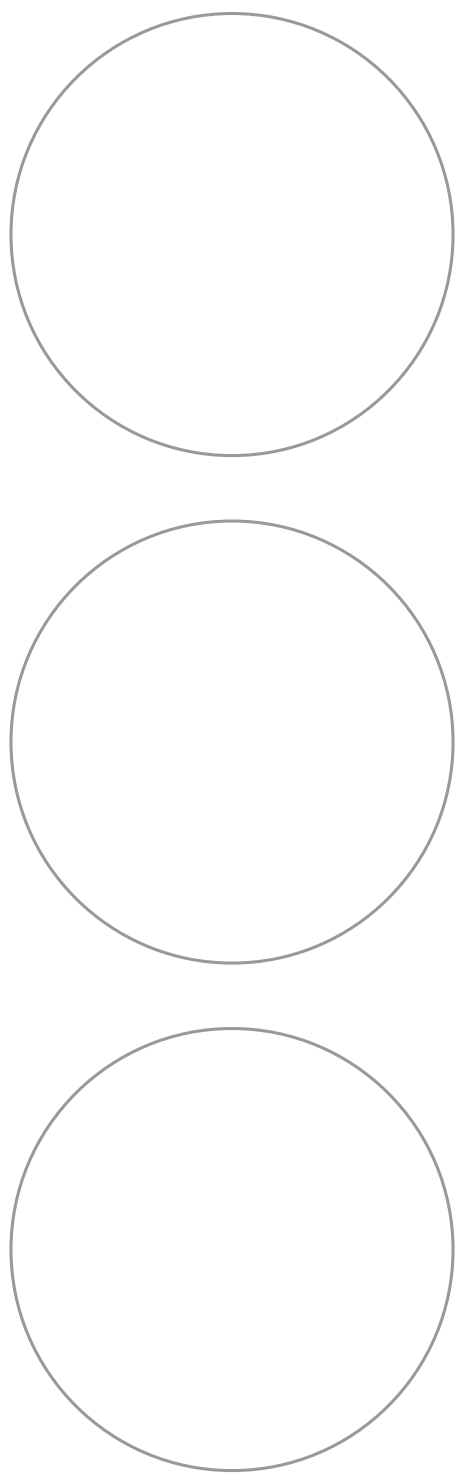

What can I do to change my feelings?
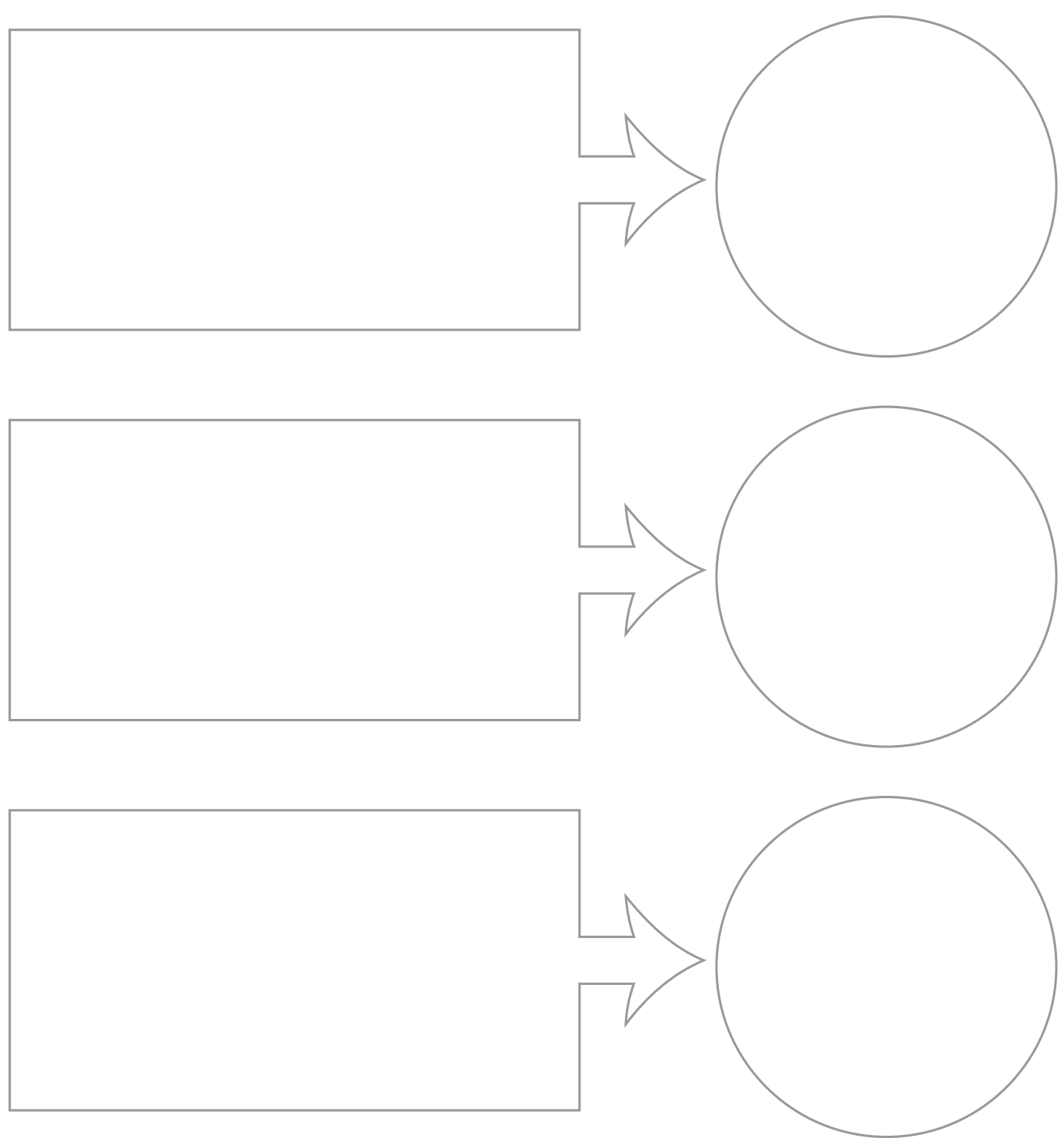


\section{5) Human Rights value my self-esteem}

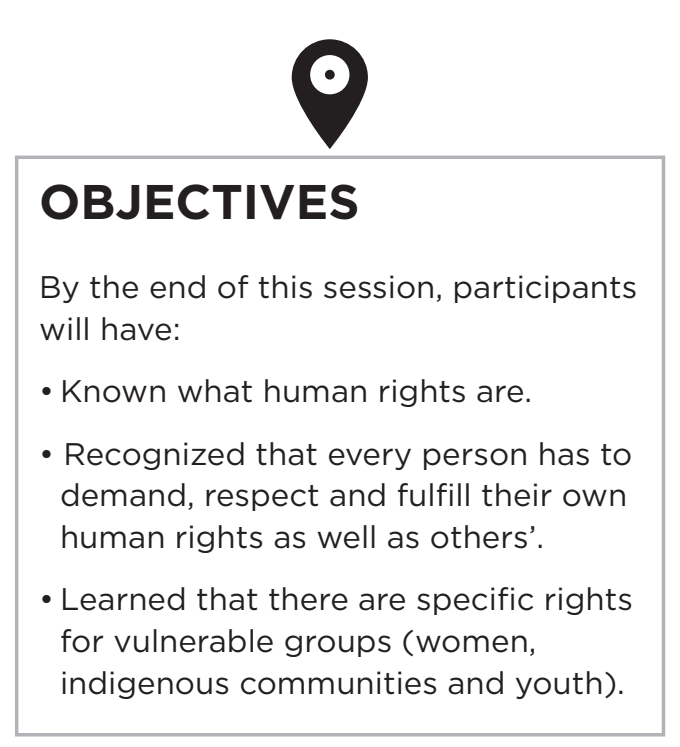

\begin{tabular}{|l|}
\hline MATERIALS \\
- Markers \\
- Posters of power groups \\
- Flipcharts \\
- Pictures of groups of \\
people affected and \\
displaced by wars and \\
conflict \\
- "Universal Human \\
Rights" worksheet
\end{tabular}
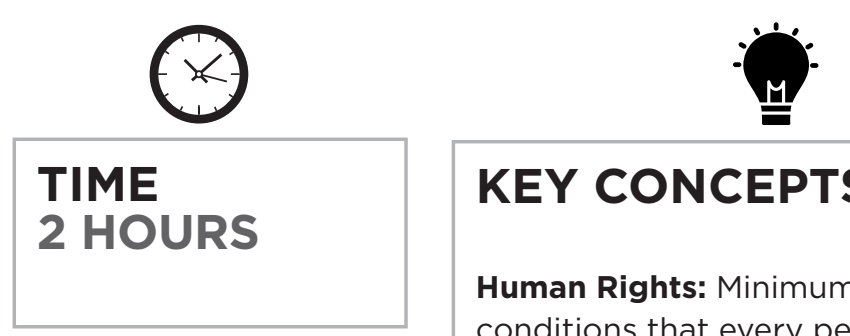

\section{KEY CONCEPTS}

Human Rights: Minimum life

conditions that every person should enjoy from the moment they are born for their personal development as human beings

Responsibility: Valuing and voluntarily meeting your own obligations, especially respecting others.

Some children's rights:

The right to a name

The right to a family

The right to education

The right to health

The right to recreation

The right to a house

Specific rights: Guarantees created to address the needs of specific groups of people that have been discriminated against and forced to live disadvantaged circumstances. 


\section{Welcame}

Welcome the participants and take attendance. Invite them to go to the doorway of the Safe Space and from there, to observe their community, identifying what things in their community are very important for their lives and the lives of their families. Participants can share their ideas from the doorway.

\section{Topic introduction}

Ask the participants to form a circle and in the center, place several pictures of communities displaced during the Internal Armed Conflict in Guatemala. Tell them that these are real pictures of Guatemalan communities thirty years ago. Let them see the pictures, comment about them, etc. While they do this, say to the participants:

These are images of Guatemala thirty years ago, when the country was living in war; when many attacks were committed against people due to their language, culture, territory, ideas about the government, the community and the goods they had. In order to survive, many of the communities had to leave their villages and got to live in the mountains, without resources or anything they could take with them. There they lived in hiding for fear of being found and suffering more violence.

Do you know stories of people, families or communities that had to run away from the places where they lived and had to live in these conditions? How were their lives?

What things do people in these pictures need to survive?

Form groups of 4 or 5 girls, and hand each group a flipchart and markers. Each group has to imagine themselves as women leaders of a community that has taken refuge in the mountains. Since they will begin a new phase, they want to make sure that everyone has a good life. Ask them to write on the flipchart ten conditions that every member of the community has to have to ensure their happiness and full development. Give them 20 minutes to work on this exercise and then have each group present its' list.

\section{Theory and definition}

Tell them about World War II and how the Universal Declaration of human rights came to exist. Say to the participants:

The war in Guatemala, the Internal Armed Conflict, was neither the first nor the only war of this type. There was World War II where many countries fought each other and there were similar conditions to those lived in Guatemala later. When the war ended in 1945, representatives from many countries got together to discuss what had happened and decided that no one wanted anything like this to ever happen again, because every human being had worth and dignity and thus they had to be respected. As an agreement between all the countries, the Universal Declaration of Human Rights was written. It's a list with all the conditions every person needs to have in order to develop themselves, participate freely, and live a better life. Similar to what you just did in your groups. It was necessary to declare these minimum conditions because some people with more power had taken advantage of others with less power, and this still happens to this date.

Hand to each girl a "Universal Rights" worksheet and read the rights together. Circle on the flipcharts the conditions that appear in the human rights declaration. For each right, give an example of how this right is or isn't met in the community.

\section{Ask the participants:}

What similarities did you find between the list we made and the Universal Declaration of Human Rights?

What does this declaration mean by universal? Who does it protect?

Which groups find it more difficult to fulfill their human rights?

\section{Children and youth \\ Women}

\section{Indigenous communities}

People with disabilities

The sick 


\section{Application in daily life \\ Analyze how access to human rights shifts according to life conditions. Dis-} tribute among the participants, papers naming one of the following social groups: White male with University degree working in the City. Indigenous male who migrated from Guatemala to México and USA*, where he works as a constructor. Indigenous female girl that has completed sixth grade in her community, her parents are arranging for her marriage. White female who works as a teacher in the rural community. You can write as many stories that reflect reality as you like.

Ask participants to consider for each person what human rights are and which aren't accessible to him/her. Every group will present conclusions and ask:

What groups are more disadvantaged?

How is the situation for girls and women?

What groups do you think need specific rights to protect them due to their increased exposure to vulnerable situations?

Which groups do you belong to?

\section{Women, youth, indigenous community}

Which situations have you experienced that show the power relationship with other groups?

How does 'Girls Creating Opportunities for a Brighter Tomorrow' begin to change this power relationship? 


\section{Universal Rights}

* Every person has the right to life and personal integrity.

* Every person has the right to freedom, no one will be enslaved.

* Every person has the right to equity and to not be discriminated against.

* Every person has the right to enjoy a violence free life.

$* \quad$ Every person has the right to information and education.

$* \quad$ Every person has the right to physical and psychological health

* Every person has the right to participate in your community's politics.

* Every person has the right to housing, food and clothes.

* Every person has the right to have a job.

* Every person has the right to have a nationality and a name.

$\star \quad$ Every person has the right to receive sexual education.

* Every person has the right to adequate, accessible and quality sexual and reproductive health services. 


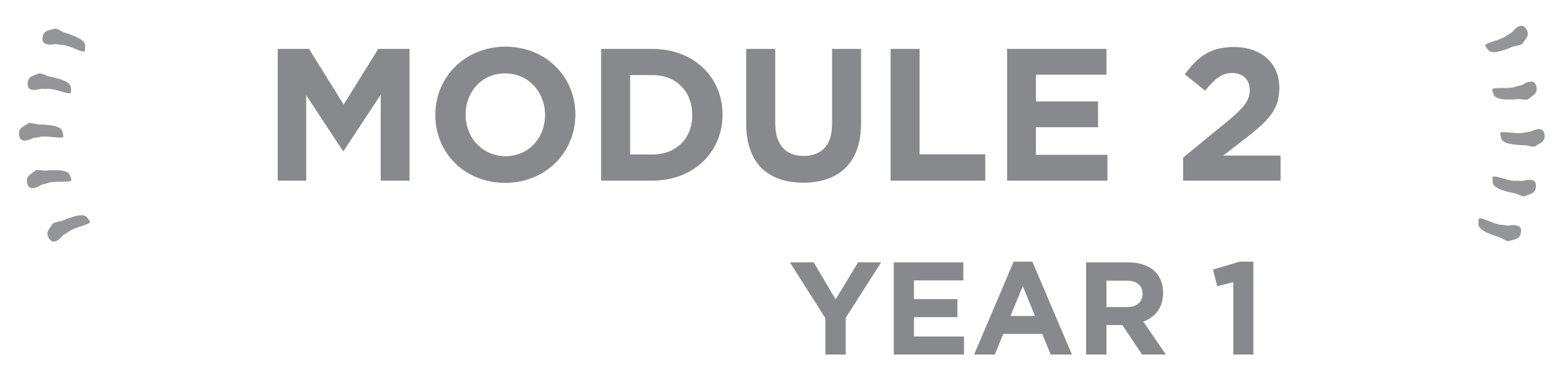




\section{MODULE 2}

\section{YEAR 1}

This module combines financial education with personal strengthening as strategies to enhance girls' and adolescents' skills to prevent violence against themselves or against other women. Working these domains in a complementary way makes it possible for girls and adolescents to identify, prevent and get away from a potentially violent relationship.

\section{Group ages 8 to 12}

2.1 Financial Education: I give to receive

2.2 Financial Education: I have to choose the best option

2.3 Violence Prevention: I see the nearby dangers

2.4 Violence Prevention: My family cares about me and can support me

\section{Group ages 13 to 17}

2.1 Financial Education: My needs: scarcity and my expenses

2.2 Financial Education: Economic justice, power and rights

2.3 Financial Education: The importance of saving money

2.4 Financial Education: Building my life: job options

2.5 Violence Prevention: I express myself assertively

2.6 Violence Prevention: I recognize when and where I am in danger 


\section{1) । give to receive}

\begin{tabular}{|l|}
\hline OBJECTIVES \\
By the end of this session, participants \\
will have: \\
- Proved that things are not for free \\
and that the satisfaction of their \\
needs demands financial resources. \\
- Identified that through their work \\
and the work of her family and \\
neighbors they produce goods and \\
services that they exchange in order \\
to satisfy their needs. \\
- Understood the exchange process in \\
the community. \\
- Talked about moments in which they \\
are producers or consumers.
\end{tabular}

\begin{tabular}{l} 
MATERIALS \\
• Posters with scenes 1, 2, \\
3 and 4 \\
- Arrows, stars or paper \\
circles \\
- Crayons \\
- Worksheet \\
\hline
\end{tabular}

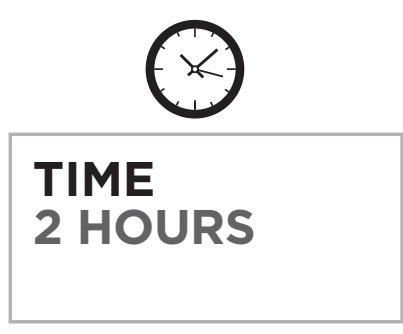

\section{, \\ KEY CONCEPTS}

Goods: Material things that are produced through work.

Work: The effort that is made in order to produce goods or receive a payment that allows you to fulfill needs or desires.

Services: Activities we do to take care of others- looking after the sick, teaching, transporting people, etc.

Exchange: Action of giving and receiving goods and services. 


\section{Welcame}

Welcome the participants and take attendance. Invite them to play "The little mouse requests". In this game there is a little girl mouse that likes to carry he things to her house, she is always requesting and requesting things. The mentor will play the role of the little girl mouse and participants will split into two teams. When the mentor asks what the little girl mouse wants, each team wil have to look amongst their participants for the things the mouse asked for and bring it to the mentor as fast as they can. Some of the things the mentor can ask for are:

- $\quad$ Something her mother bought for them in the market.

- One thing they made for themselves.

- A resource they can use to buy other things.

- Something they need to live well and stay healthy.

After putting all the objects up front, talk with the girls about where they have gotten the items that they found. Ask three participants to share where some of their garments come from. Make sure they are things that require a purchase (sweater, shoes, sash, traditional skirt, güipil, etc.). Take advantage of this opportunity to talk about the importance of everyday exchange where we give something and get something in return.

\section{Topic introduction}

Tell them the following story and hang the scenes up where everyone can see:

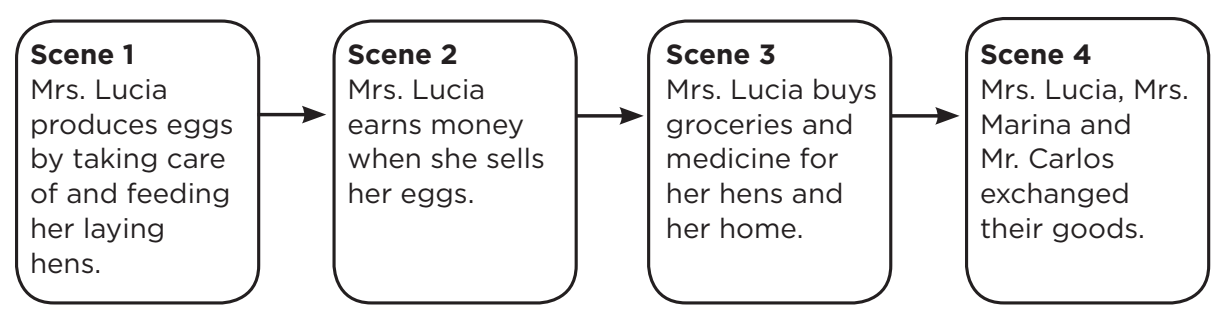

\section{Story: "Trading"}

Mrs. Lucia owned a laying hen business and sold eggs. One day, Mr. Carlos asked her to sell him a dozen eggs and she gladly did. With the money from the sale, Mrs. Lucia went to the market and bought groceries for her family. Then she went to Mrs. Marina's store- a woman who was really happy to see her- and sold her all the products at a very good price. That way she ensures that Mrs. Lucia will come back. At the end of the day, Mr. Carlos ate the 12 eggs with his family. Mrs. Lucia bought everything she needed for her hens, and Mrs. Marina saved some money with what she sold in order to buy medicine for her mom.

\section{Theory and definition}

3 Ask the following questions and point out the answers in the pictures. You can use arrows, stars, circles or any other figure to underline the key concepts:

What is Mrs. Lucia's job?

\section{She produces eggs}

What did Mrs. Lucia sell to Mr. Carlos?

\section{Eggs}

What did Mr. Carlos give Mrs. Lucia in exchange for the eggs?

\section{Money}

What service did Mrs. Marina offer to Mrs. Lucia?

\section{Sell her products from the store}

How did Mrs. Marina's job help her mother's health?

\section{The sale allowed her to save some money to buy medicine}

How do you think that the characters felt at the end of the day?

Explain that at different points we are producers or workers, and in other moments we are consumers. When we do a job we are producers and we receive money to produce goods and/or services; when we pay for a service or buy a good we are consumers.

When is Mrs. Marina a worker? When is she a consumer? 


\section{Aprlication in daily life} to draw a picture of a working, producing and consuming woman from their families or communities on a white sheet of paper. When they finish, they can share with the rest of the group by answering:

Who is the woman they drew?

What is her job?

What does she produce?

What does she get in exchange for her work?

What does she do with the money she earns?

How did she learn to do her job?

Talk with the girls about the effort that it takes to make things to sell and that it takes knowledge and resources in order to buy the materials that later will be transformed into the final product.

Ask the girls what are the main products in their community and how do these products satisfy the needs of other people and other communities.

Discuss with the girls about how in the family everyone has responsibilities and a lot of times the women work even though they do not receive a salary in exchange. Ask them to give you examples. Ask these questions and write the answers on a poster:

What work do the women and girls do at home and in the field?

Write down the answers in a flipchart and ask them to underline the ones that they do without receiving a payment or anything in exchange.

What can we do to take care of the things that we use and that we have

thanks to the work of our family, community and environment?

Lead participants in a dialogue about the efforts that they do when they study. Tell them that what they learn today will be useful in order to produce and exchange goods and services to satisfy their needs.

What things that you learned today can help you to be productive in the future?

For example: mention the crafts that they have worked on. 
'GIRLS CREATING OPPORTUNITIES FOR A BRIGHTER TOMORROW' PROGRAM INTEGRATED CURRICULUM GUIDE

\section{Women that move the economy}




\section{2) I have to choose the best option}

\begin{tabular}{|c|c|c|c|}
\hline $\begin{array}{l}\text { OBJECTIVES } \\
\text { By the end of this session, participants } \\
\text { will have: } \\
\text { - Distinguished between needs and } \\
\text { desires. } \\
\text { - Selected their needs over their } \\
\text { desires. } \\
\text { - Valued the usefulness and effort that } \\
\text { a saving habit requires. } \\
\text { - Proposed strategies to save } \\
\text { resources and money. }\end{array}$ & $\begin{array}{l}\text { MATERIALS } \\
\text { - Bucket } \\
\text { - Mat } \\
\text { - Big piece of plastic } \\
\text { - Basket } \\
\text { - Flipchart } \\
\text { - Markers } \\
\text { - } 4 \text { stories to hand out }\end{array}$ & $\begin{array}{l}\text { TIME } \\
2 \text { HOURS }\end{array}$ & $\begin{array}{l}\text { KEY CONCEPTS } \\
\text { Need: What one must have in order } \\
\text { to live a dignified and healthy life. It } \\
\text { can be material or not. } \\
\text { Desire: Goods or services that are } \\
\text { wanted, but that do not fulfill any } \\
\text { basic needs. } \\
\text { Usefulness: Quality of a good or } \\
\text { service that satisfies a need. } \\
\text { Choice: Ability to choose between } \\
\text { one thing or another based on our } \\
\text { needs and preferences. } \\
\text { Budget: An income and expense plan. } \\
\text { Satisfaction: The result of having } \\
\text { ones' need or desire fulfilled. } \\
\text { Saving: Money and/or resources that } \\
\text { are preserved without being used in } \\
\text { order to accumulate with more money } \\
\text { and/or resources to be used in larger } \\
\text { quantities. }\end{array}$ \\
\hline
\end{tabular}




\section{Welcame}

Welcome the participants and take attendance. Tell them that today they are going to choose from different objects the best alternative to satisfy a specific need they have.

Ask them to give examples of things that they have chosen this week.

\section{Topic introduction}

They will start by playing "You have to choose, so that the weather does not get you wet”. Five volunteers will move to the center. Each will have one of the following object: large piece of plastic, bucket, newspaper, mat. The mentor announces the weather forecast and all the participants run towards the volunteer that has the object that will protect them best. Some of the weather predictions the mentor can use are:

1. The sky is gray, the wind is starting to blow, and the rain is falling. I don't want to get wet!

2. The sun is shining strong, I almost cannot see you, and my skin is starting to burn. I have to cover up with something!

3. The wind is blowing so fast that I feel like I can fly, I am really cold. I have to wear something!

4. The sky does not want to let any water go, the poor plants are going to dry. Tell me what can I use to water the plants if I don't have a hose!

\section{Theory and definition}

Talk to the girls about how, ever since we are little girls, we have to make decisions and choose from alternatives. We choose what to eat, what to play, if we come to this group or not. Every time we choose there is an opportunity to take care of our resources and save. Ask them to work together to create the meaning of choosing and write the correct answers on a flipchart. Then, participants have to define need. Write down the correct ideas too. Finally, they have to do the same with the meaning of desire.

\section{Application in daily life}

Divide the participants into four groups. Hand each group one of the stories, ask them to read it and then plan to act out the story and present it to the rest of the girls.

\section{Group 1:}

Juana went to school and her homework was to make a poster with the parts of a plant. She noticed that she needed to buy things for her poster and thought about buying paper, yarn, glue, scissors, glitter, and colored cardboard papers. When she asked her mother for money, her mother gave her only Q.2.00. That wasn't enough to buy everything she wanted at the store. So, Juana chose the most important things: paper, scissors and glue. With these three things, she made a beautiful poster.

\section{Group 2:}

In the morning, Fabiola accompanied her father to town to buy things for sowing crops. There were so many things to buy in town and they were all beautifu things. Fabi started to ask and ask her father to buy her a lot of things and he bought them. At the end, they could not buy everything necessary for sowing and they were only able to harvest half of what they normally did.

\section{Group 3:}

Sonia's mom had a bad flu, so they went to the town's pharmacy to buy medicine. There they offered them two options: a colorful box with beautiful letters on it and the picture of a pretty lady who seemed to be feeling good that had pills that cost Q 5.00 and another box with simple letters, no color or picture that had white pills that cost $Q$ 1.00. The woman at the pharmacy told them that both medicines were the same and worked the same- the only difference was the box and the name. Sonia's mom bought the white pills and had enough money left to buy several pills for next time someone at home got sick. 


\section{Group 4:}

One day, Julia accompanied her mother to the store. They had Q 40.00 to

buy chicken, vegetables, and rice. They were going to cook a delicious meal.

In the store Julia saw many colorful and vibrant ribbons and begged her mom so much to buy them for her that in the end she bought them. However, she

was not able to buy enough chicken and lunch was a vegetable soup with rice and some chicken.

Give them 10 minutes for the groups to read the story and plan their skit. Next, they have to present it to the rest of the girls.

After each presentation, ask:

What did they need to buy?

What did they desire?

Between what options did they have to choose?

Did they choose what they needed or what they wanted?

Was the result good for them or was it harmful?

Put up two flipcharts and hand out markers. Ask participants to draw their needs on one and their desires on the other. 


\section{3) I see nearby dangers}

OBJECTIVES
By the end of this session, participants
will have:
- Identified dangerous places in their
community.
- Evaluated which behaviors can put
them in danger.
- Thought about strategies to avoid
dangers.

MATERIALS
- Community map
- One piece of paper for
each girl
- Flipchart
- Markers and crayons
- Red yarn
- Red, yellow, and green
circles

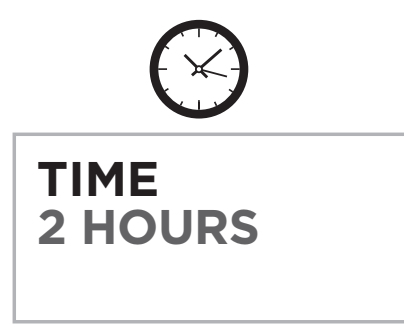

\section{KEY CONCEPTS}

Dangerous place: Places where something can happen to me that can cause me physical, emotional, economic damage or any other type of harm.

Risky behavior: Actions that put my wellbeing at risk and expose me to people that might cause me harm.

Prevention: Attitude concerning the decisions I take in order to avoid risky and harmful situations. 


\section{Welcame}

Welcome the participants and take attendance. Give each girl a little piece of paper. Ask them to draw how they feel when they are in the safe space of Girls Creating Opportunities for a Brighter Tomorrow. They can share their answers, putting the papers on their hearts. Talk with them about how they feel when they are in the 'Girls Creating Opportunities for a Brighter Tomorrow' safe space and what have they learned here in the time they have been attending

\section{Topic introduction}

They will start by playing "You have to choose, so that the weather does not get you wet". Five volunteers will move to the center. Each will have one of the following object: large piece of plastic, bucket, newspaper, mat. The mentor announces the weather forecast and all the participants run towards the volunteer that has the object that will protect them best. Some of the weather predictions the mentor can use are:

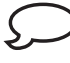

Place the community map for everyone to see and ask them:

Are there any other places in the community where you feel safe other than our safe space?

Invite the girls to use their green circles to identify those places on the map.

Share with them that it is important to know those places in the community so they know where they can go. Identifying safe places means they know if they will be secure, knowing what happens in those places, who lives there, whether you like to go or not, and the way you are welcomed and treated in those places. Based on all that information, the girls and adolescent girls have to make intelligent decisions about which places to go and how to reach those places, as well as identifying the places where that can put them at risk of harm.

Put the map at participants' reach and ask them to complement it drawing any spaces that are missing.
They can draw:

- Catholic church

- Evangelical church

- The plaza

- Bus stops

\section{- Streets}

- Roads

- Grocery stores

- Local bars
- Health centers
- Very tall cornfields

- Inside trucks and buses

\section{Theory and definition}

Read the definition of the 'dangerous place' concept to the group. Go back to the map and ask participants to dialogue and classify spaces according to degree of safety. They will put a red circle on those places that are high risk yellow on the ones that are partially safe and green on those who are completely safe. Take time to discuss about each place ensuring participants are truly analyzing.

Next, read together the definition of 'dangerous behavior' and 'prevention', and ask them to give examples of dangerous behavior and risk prevention. Under each definition write the examples that they give you.

Lay a piece of red yarn on the floor and ask all the participants to step on it. Instruct them to listen to the list of behaviors you will read aloud and if the behavior is risky they have to jump back from the wool and if the behavior is preventive they have to jump front. After each behavior they have to return to the wool. The following is a list of behaviors for the game:

- Walk with a friend when walking down lonely roads and streets.

- Go all by yourself to the store late in the evening to buy candy.

- Talk with people you don't know, but seem nice.

- Notify at home, where you're going, who you are going with and how long you will be gone.

- $\quad$ Saying you are going to the market, but then going somewhere else without notifying anyone.

\section{Application in daily life}

Ask them to form couples and assign to each a place that was identified as risky. Participants shall think strategies they can use to prevent dangers pairs and each pair will get one of the places identified as risky. They must think of a risky behavior and two prevention strategies in case they have to walk near or go to the place that was assigned to them. You can arrange the participants into more or less groups according to the number of identified places. They should work briefly and then share with the rest of the group. Make a list of the prevention behaviors they came up with. 


\section{4) My family cares about me and can support me}

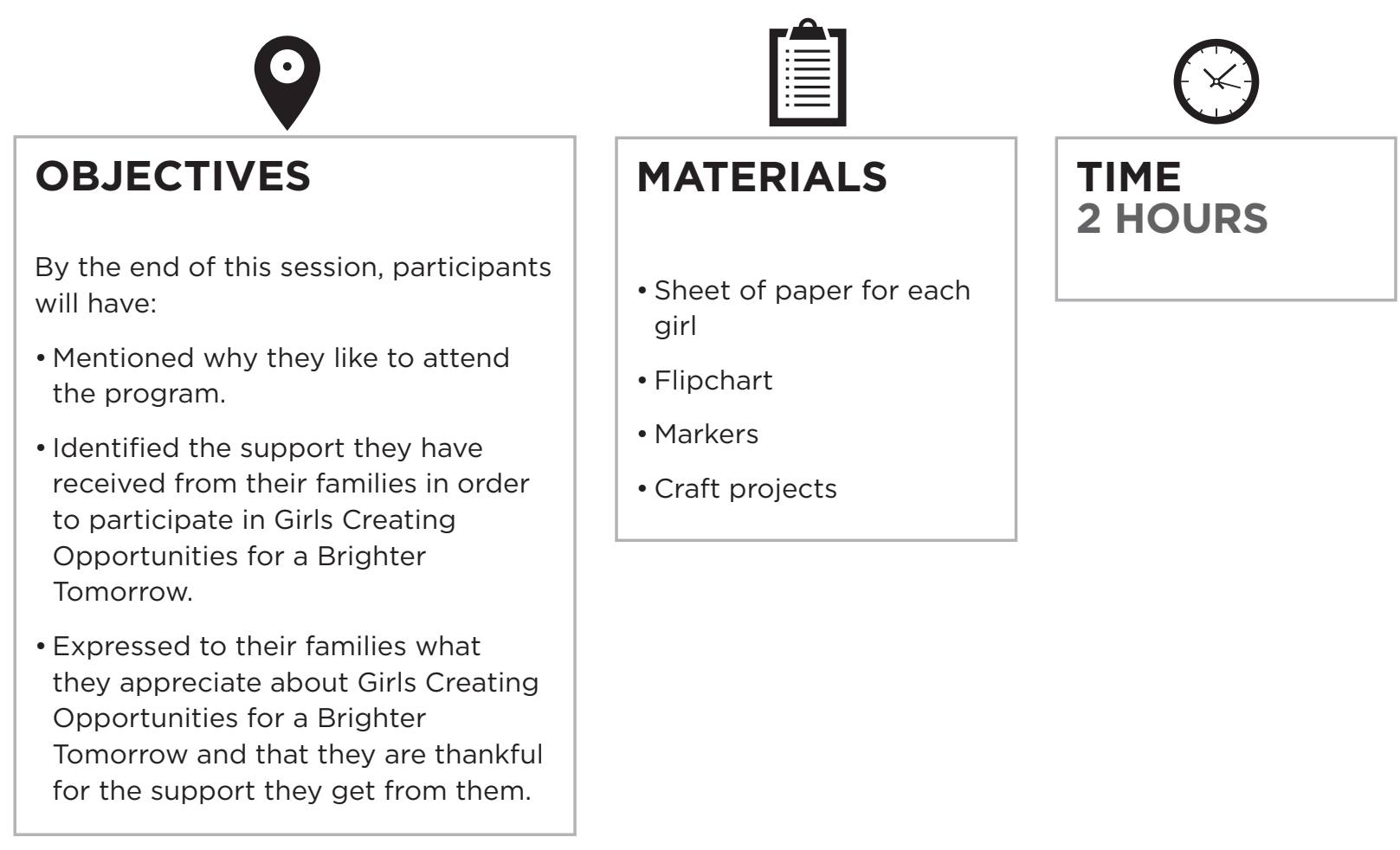

KEY CONCEPTS
Family: Group of closely related
people that live together and develop
relationships based on love and trust.
This group takes care of one and
other and supports each individual's
development.
Appreciation: Feeling of gratitude
toward those things that make us feel
good and helps us grow.




\section{Welcame}

Welcome the participants and take attendance. Tell them that today they are going to start by playing a game that teaches them the importance of working together and communicating.

\section{Topic introduction}

Invite the participants to play the Human Knot game. Ask them to form a tight circle and have everyone reach into the center. Each one should grab a hand from the person standing across the circle. Each girl must hold hands with two different girls. Next, they must look for a way to untangle and form a regular circle without ever letting go of one another's hands.

\section{At the end ask:}

What was the goal of the game?

What was the difficulty?

What did you do to untangle?

How did it help you to communicate with each other?

What things have you learned in Girls Creating Opportunities for a Brighter Tomorrow that have helped you in your lives?

How has your family helped you to continue participating in the program?

What benefits does a family have when there is communication among family members?

\section{Theory and definition}

Talk with the participants about the importance of recognizing when we receive something that helps us and the importance of giving thanks. Say to them:

Communication is very important in a group so every group member can reach their goals and feel happy. Here, in 'Girls Creating Opportunities for a Brighter Tomorrow', you found a safe place where you can come and talk, ask questions, learn, play, make handcrafts, etc., and learn things that help you make better decisions in your lives. Let's think for a moment about all the activities that we have done here in our 'Girls Creating Opportunities for a Brighter Tomorrow' safe space.
Invite them to approach one of the walls where you have hung the posters you've used in past sessions and some of the work they have done throughout the year and have them paste the star with their name on it on the activity they liked the most.

Next, have participants move into groups of three. Ask them to share how their family reacted when they started to go to the group and how it is now. They can tell stories. Ask that one person from each group share with the rest about how the families' support towards the program may have changed. Take notes on a flipchart about what they said.

Say:

Our family often cares about us and if our family knows us, they know what we want to do, what we like and what interests us. It is important to do two things: tell our families about our lives and also thank them when they support us in something we like and helps us grow. We are also going to make a list of all the things our families do to support us and we'll write them down on this poster.

Write on a flipchart what the girls share about the ways their families have helped them to come to 'Girls Creating Opportunities for a Brighter Tomorrow'.

\section{Application in daily life}

Each girl is going to write on a piece of paper a requset linked to AOsomething that she has always wanted to ask her family but she is ashamed or does not know how to do it. They are going to make a paper plane with their requests and will go out to the yard to fly them. Each girl will have to pick up another participant's paper plane, and create a strategy to talk to her family about it. Participants can share their solutions in order to receive input from other group members. 


\section{1) My needs: scarcity and my expenses}

OBJECTIVES
By the end of this session, participants
will have:
- Differentiated between needs and
wants/desires.
- Made a decision about how to
manage their financial resources
while prioritizing their needs.
- Learned how to make a budget.

\begin{tabular}{|l|}
\hline MATERIALS \\
• Key concepts on posters \\
• Markers \\
• Flipcharts with budgets \\
• "Family budget" \\
worksheet
\end{tabular}

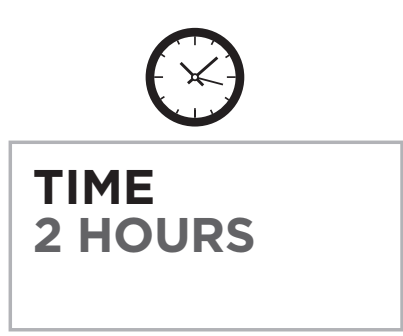

Need: What one must have in order to live a dignified and healthy life. It can be material or not.

Scarcity: Insufficient resources to satisfy our needs and desires. The resources we don't have (money, time...).

Desire: Goods or services that are wanted, but that do not fulfill any basic needs.

Income: Money we receive from different people, either in exchange for a job or for us to carry out some activity.

Expense: Money we use to buy goods or pay for services.

Budget: Tool that helps to order the flow of money, and record income and expenses by the day. 


\section{Welcame}

Welcome the participants and take attendance. Tell the participants that today they are going to read a story about needs, desires and expense planning.

\section{Topic introduction}

Tell the following story to the participants. Ask

for two volunteers to come up front and one of them will be Rosi and the other, Flory.

\section{"The Goalie"}

Rosi and Flory were watching the soccer game the

\section{Teaching Tip \\ Let both volunteers read the story first and practice before acting it out in front of the group.}

'Girls Creating Opportunities for a Brighter Tomorrow' team was playing.

Rosi: -They say an unlucky goalie is not a goalie at all.

Flory: -To be a good goalie, the most important thing is to never lose sight of the ball.

Rosi: -Looks like you know a lot about soccer...

Flory: -Yes, I'm the best goalie in school. But, now I need new sport shoes.

Rosi: - Sport shoes? The ones you have don't work anymore?

Flory: -Yes, but I want to wear brand new ones for next month's championship ... and I also have to buy new markers for school homework.

Rosi: -Why don't you buy them with the money you made helping your mother? The AO program has taught you how to save part of it to buy anything you want or need in the future.

Flory: -The thing is... I don't have the money. I spent it all.

Rosi: -On what?

Flory: -l don't remember...

Rosi: -What do you mean you don't remember?
Flory: - Well... I bought some cookies, a very pretty purse with vibrant colors, and then I invited some friends for ice cream... and I don't know what else I did with the rest of the money.

Rosi: -I suggest you make a budget so you know how much money you have, to plan your expenses.

Next, ask the participants the following questions:

Why can't Flory have new sport shoes and markers?

What are her needs? Which do you have in common with her? What are the needs of your community?

What do you do to get what you need?

Have you ever run out of money and didn't know how you spent it?

\section{Theory and definition}

Divide participants into six groups and hand each group one poster with a key concept written on it. Ask the group to read the concept, explain it in their native language and look for examples of the concept in their community. Then, each group will present their examples to the rest of the girls. After they have finished, explain to the participants:

We all have needs: of a house (housing), clothes to wear (clothing), daily food (food), doing an activity that pleases us like going for a walk or getting together with a friend to chat (entertainment). We buy things and pay for services to satisfy those needs: food, a house, books, transportation, etc. Sometimes the things we want are not needs, but desires; something we fancy; something we want, but it's not important to have it.

The resources we have for satisfying needs and desires are scarce or limited. We cannot always buy everything we like with the money we have; so it is necessary to choose the most important things. A recommendation for making better decisions on how to spend our money is making a budget. Where we write down the amount of money we receive, in other words, our income, and the amount of money we spend during a period of time. Making a budget helps us know how much money we have and where we use every dime from our income. It also helps us identify if we spend more than we have. In a budget, we can write down the things we need to buy in the week or month in order to know how much money we need to pay for it and thus set apart the money before we start spending it. 
Ask a participant what her monthly income is and write it on a flipchart. On another flipchart write down their expenses. Explain these two lists based on a budget. Show them on a flipchart an example of a budget and explain the elements that make it up by identifying income,

expenses, balance, dates, etc.

After they have become familiarized with a budget, show them two more examples so the participants can see the three following budgets. Ask them to come up close and study them.

\begin{tabular}{|l|r|}
\hline \multicolumn{2}{|c|}{ Case 1 } \\
\hline Income & Q1,000.00 \\
\hline Father's income & Q1,000.00 \\
\hline Mother's income & Q500.00 \\
\hline $\begin{array}{l}\text { Other family member's } \\
\text { income }\end{array}$ & Q2,500.00 \\
\hline Total income & Q600.00 \\
\hline Expenses & Q250.00 \\
\hline Food & Q180.00 \\
\hline Housing (rent) & Q100.00 \\
\hline $\begin{array}{l}\text { Services (water, } \\
\text { lighting, mobile) }\end{array}$ & Q60.00 \\
\hline Health (medicine) & Q1,265.00 \\
\hline $\begin{array}{l}\text { Installment } \\
\text { payment for something }\end{array}$ & Q1,235.00 \\
\hline Transportation & \begin{tabular}{l|} 
Total expenses \\
\hline $\begin{array}{l}\text { Balance (Income - } \\
\text { expenses) }\end{array}$
\end{tabular} \\
\hline $\begin{array}{l}\text { Income higher than expenses: When } \\
\text { income is higher than our expenses, } \\
\text { we are in a good scenario. We have an } \\
\text { excellent opportunity to save money or } \\
\text { deal with an unexpected event. }\end{array}$ \\
\hline
\end{tabular}

\begin{tabular}{|l|r|}
\hline \multicolumn{2}{|c|}{ Case 2} \\
\hline Income \\
\hline Father's income & Q500.00 \\
\hline Mother's income & Q265.00 \\
\hline $\begin{array}{l}\text { Other family member's } \\
\text { income }\end{array}$ & Q1,265.00 \\
\hline Total income & Q600.00 \\
\hline Expenses & Q250.00 \\
\hline Food & Q180.00 \\
\hline Housing (rent) & Q75.00 \\
\hline $\begin{array}{l}\text { Services (water, light- } \\
\text { ing, mobile) }\end{array}$ & Q100.00 \\
\hline Health (medicine) & Q60.00 \\
\hline $\begin{array}{l}\text { Installment } \\
\text { payment for something }\end{array}$ & Q1,265.00 \\
\hline Transportation & 0.00 \\
\hline Total expenses & $\begin{array}{l}\text { Balance (Income - } \\
\text { expenses) }\end{array}$ \\
\hline $\begin{array}{l}\text { Income is the same as expenses: When } \\
\text { income is the same as our expenses, } \\
\text { we have balanced finances, but any } \\
\text { unexpected event may cause some } \\
\text { unbalance. }\end{array}$ \\
\hline
\end{tabular}

\begin{tabular}{|l|r|}
\hline \multicolumn{2}{|c|}{ Case 3 } \\
\hline Income & Q600.00 \\
\hline Father's income & Q500.00 \\
\hline Mother's income & Q50.00 \\
\hline $\begin{array}{l}\text { Other family member's } \\
\text { income }\end{array}$ & Q1,150.00 \\
\hline Total income & Q600.00 \\
\hline Expenses & Q250.00 \\
\hline Food & Q180.00 \\
\hline Housing (rent) & Q75.00 \\
\hline $\begin{array}{l}\text { Services (water, } \\
\text { lighting, mobile) }\end{array}$ & Q100.00 \\
\hline Health (medicine) & Q60.00 \\
\hline $\begin{array}{l}\text { Installment } \\
\text { payment for something }\end{array}$ & Q1,265.00 \\
\hline Transportation & Q-115.00 \\
\hline Total expenses & $\begin{array}{l}\text { Balance (Income - } \\
\text { expenses) }\end{array}$ \\
\hline $\begin{array}{l}\text { Income lower than expenses: When } \\
\text { income is lower than our expenses, we } \\
\text { are in trouble. We need to spend less or } \\
\text { try to increase our income. }\end{array}$ \\
\hline
\end{tabular}

$\int$ Ask the participants:

What are the differences between the three budgets?

What happens if there's a good balance in the budget?

What happens if there's no balance in the budget?

What happens if the expenses are more than the money we have?

Which is the most convenient budget? And why? 


\section{Application in daily life} them to find out the weekly incomes of their family, with their parents' help. They must write down on a notepad everything their families spend money on (even if it is a small amount). Once they have a week's expenses, they have to prepare a budget using the following table:

\section{Family Budget Format}

\begin{tabular}{|l|l|}
\hline Total family weekly/ monthly income: & Q \\
\hline Expenses: & \\
\hline Food & Q \\
\hline House & Q \\
\hline Health & Q \\
\hline Transportation & Q \\
\hline Electricity & Q \\
\hline Telephone & Q \\
\hline Water & Q \\
\hline Clothing & Q \\
\hline Pending debts & Q \\
\hline School & Q \\
\hline Total Expenses & Q \\
\hline Balance & Q \\
\hline
\end{tabular}




\section{2) Economic justice, power and rights}

OBJECTIVES
By the end of this session, participants
will have:
- Gotten to know their labor, economic
and social rights.
- Evaluated how their human rights
are respected in conditions of labor,
family and community.
- Created a strategy to achieve
support for their rights.

MATERIALS
- News regarding a group
of people who demand
changes in life conditions
- Pictures of boys and girls
from different parts of
the country
- Informative materials
about labor, economic,
social and cultural rights
- Flipcharts with questions
- Markers

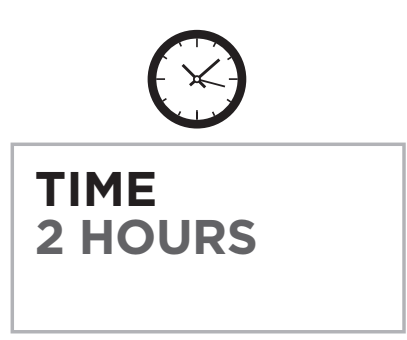
labor that allow for the development of the workers as well of their families. Economic, social and cultural rights: Human rights related to economic resources, access to social services and identity so that every human being enjoys a life with dignity. 


\section{Welcame}

Welcome the participants and take attendance. Share with them that today they are going to talk a lot. Hopefully the cat does not have their tongue!

\section{Topic introduction}

Read together with the participants some recent news on a group of people who are unhappy with their living conditions or their working conditions. Then comment on the news together.

\section{Say the following to the participants:}

\section{Why are they unhappy?}

What is causing it?

What do these people want?

Why is it a problem for their lives?

How does that problem affect their families?

\section{Theory and definition}

Make groups of three and give each group the image of a boy or a girl. Remember to include pictures of boys and girls from different areas of the country, different ethnic groups, cultures and conditions. Ask each group to create a story about the girl or boy that they got and to think about how much the $\mathrm{girl} /$ boy can develop under her/his circumstances. They can name her/him, imagine where the person lives, what they do, what their parents do, their dreams, what opportunities they have, and what their future is going to be like.

Ask them to come back and form one big group, and open up the space for them to share the stories they created about their boy/girl. Place a string on the wall and tell them that it represents the girls' and boys' development. They have to place the images in order according to how much each one of them can develop in their lives. They should discuss this at length to reach an agreement. Then ask them:
Why do some kids develop more than others?

How do their families' life conditions affect their development?

Who has had more opportunities?

Is there any difference between the boy's opportunities and the girl's opportunities?

Why do the girls and adolescent girls stop studying before the boys? How does this affect the girl's opportunities and their development? What conditions should we have in order to fully develop ourselves?

Introduce the labor, economic, social and cultural rights topic by asking: What are human rights?

Which ones do you remember?

Which human rights are respected or not in the kids' stories?

What conditions should be rights for every population?

Hand out the materials with information about labor, economic, social and cultural rights to each participant. Read the materials with them and explain the information that is presented to them. Use examples and invite the girls to think of examples based on their own experiences. To finish up the reading ask:

What relationship is there between human rights and children's development?

What state institutions should guarantee people labor, economic, social and cultural rights?

How would the lives of some girls and boys be changed if they were guaranteed rights?

\section{Application in daily life}

Form three or four groups. Give each group a flipchart with a question from one of the four vignettes for them to answer:

1. What job is more common for women in this community? Under what conditions is the job given? What is the payment? What freedoms do they have? How can they handle it with their child and husbands?

2. How many years do adolescent girls in the community study? Why do they stop studying? What difficulties do the families have to keep their kids studying? What support do they get from the government in order to be able to keep studying? 
3. Under whose name are the lots in the community registered? Is it common that a lot of land is registered under a woman's name? How is the decision made?

4. What are relations between men and women in the community like? What are the differences between how a boy and a girl are raised?

At the end ask them to exchange flipcharts with another group. They have to read it and identify:

- The rights that are being hurt

- The institutions that should be guaranteeing the rights, but are not

- An action that the women can take in order to take care of their rights

Share the answers with the rest of the group. 


\section{MENTOR STUDYING RESOURCE}

\section{Summary of the International Covenant of Economic, Social and Cultural Rights}

The economic, social and cultural rights (ESCR) constitute a broad category of human rights. Nearly every country in the world guarantees these rights. They include:

Rights at work: just and fair employment conditions, protection against forced labor or compulsory labor, and the right to form and join trade unions. For example, when the same job pays lower salaries to women than men, in this case women's right to work is not being complied because it is not under fair employment conditions.

The right to education, guaranteeing, for example, the right to free and compulsory primary education, to sufficiently available, accessible, acceptable and adapted education for each individual. For example, the right to education is being denied when there are no schools in your community or the teacher is never present.

Cultural rights of minorities and indigenous people. For example, if you were forbidden to wear your traditional clothing or speak your language, you are being denied of your cultural right.

The right to the highest attainable standard of physical and mental health possible, including the right to healthy living conditions and available, accessible, acceptable, and quality health services. For example, when the health center does not have medicine available, you don't have the right to physical health
The right to adequate housing, including security of tenure, protection from forced eviction and access to affordable, habitable, well located and culturally adequate housing. For example, if you were evicted from your house because the property doesn't belong to you, you are being denied the right to adequate housing.

The right to food, including the right to freedom from hunger and access at all times to adequate nutritious food or the means to obtain it. For example, if the maize price were to increase and you no longer can buy it because it's too expensive, you are being denied your right to food.

The right to water, in other words, the right to sufficient water and sanitation facilities that are available, accessible (both physically and economically) and safe. For example, when you have to walk long distances for fetching water because you do not have running water in your house, you are being denied the right to water. 


\section{3) The importance of saving money}

\begin{tabular}{|c|c|c|c|}
\hline $\begin{array}{l}\text { OBJECTIVES } \\
\text { By the end of this session, participants } \\
\text { will have: } \\
\text { - Understood what saving is, and } \\
\text { identified different kinds of saving. } \\
\text { - Thought of saving as a strategy that } \\
\text { allows them to reach their goals and } \\
\text { overcome emergencies. } \\
\text { - Created strategies to initiate or } \\
\text { enhance their saving habits. } \\
\text { - Identified different saving options } \\
\text { and different financial institutions. }\end{array}$ & $\begin{array}{l}\text { MATERIALS } \\
\text { - Stories: The Boyfriend } \\
\text { and The Parents } \\
\text { - Flipcharts } \\
\text { - Markers } \\
\text { - Worksheet }\end{array}$ & $\begin{array}{l}\text { TIME } \\
2 \text { HOURS }\end{array}$ & $\begin{array}{l}\text { KEY CONCEPTS } \\
\text { Savings: The habit of setting aside a } \\
\text { part of one's income without spending } \\
\text { it. This allows a person to make bigger } \\
\text { investments to reach goals or to } \\
\text { overcome emergencies that can come } \\
\text { up. } \\
\text { Saving options: There are different } \\
\text { savings options: banks, microfinance } \\
\text { institutions, credit unions, our homes, } \\
\text { community savings groups and other } \\
\text { types of financial institutions. We must } \\
\text { find out which financial institutions } \\
\text { are available in our community. Each } \\
\text { savings option has its pros and cons. } \\
\text { It depends on us to decide which type } \\
\text { of service we need and which savings } \\
\text { option best meets our needs. }\end{array}$ \\
\hline
\end{tabular}




\section{Welcame}

Welcome the participants and take attendance. Ask then to share their dreams... if they had Q10,000 of their own...

How would you use it?

What would you invest in?

How long would it take them to save that amount?

Does anybody in the group have savings? How do you do it?

\section{Topic introduction}

Ask the participants to form a circle. Present the title of the story on a flipchart and ask them what they think the story is about. After they give their ideas, read the story.

\section{"A visit from the Savings Wizard"}

(Adapted from www.valores.com.mx/ Stories by Verónica Huacuja)

Ana is a young woman whose mother gives her Q 1.00 for school. She saves half of that money every day by putting it in her piggy bank. By the end of the year she has saved Q 90.00! But, for Ana, having so much money is a problem because she does not know what to do with the money. She wants to buy so many things and at the same time she does not want to spend it all. She wants to buy her favorite candies, a bag of sequins at the store around the corner and visit her grandmother who she barely sees because she lives very far away.

Her situation reached the ears of the Savings Wizard, who took her magic wand and flew to visit the young girl. When she arrived she said:

- Hello, Annie, I come to give you advice on the best plan to spend your money, but also to continue saving it.

-You really understand me, Wizard! - The young girl exclaimed with excitement.

-I know exactly what you mean - replied the Wizard. -You want to know how to use your money without spending it all. In other words, to properly plan what you can do with your savings.

Then, she waved her magic wand and caused a pencil and a notepad to appear, and wrote:
-This is the magic formula! You can save in three ways: in the short-, mediumand long-term. In short-term, it means you can save money for short periods of time, such as for a couple of days, to buy something inexpensive like the candy you like so much. Medium-term savings means that you save for more or less long periods of time, such as for a couple of weeks, to buy something a little bit more expensive, like school supplies you need. Now, long-term savings means that you save for even longer periods of time, such as for a few months, for something that is more expensive like your trip to visit your grandmother for your vacation at the end of the year.

-Wow! That means / can save, spend and keep saving?

-That's right! —smiled the Wizard - you can do it this way.

So, the young girl pulled out a calendar from her drawer, took the pencil and notepad the Wizard gave her and began planning her savings and purchases. She did some calculations and noticed that the money she had saved was enough to buy everything she wanted and still continue to save for other goals. She would you use a different piggy bank for each type of savings: a yellow one for short-term, an orange one for medium-term and a blue one for long-term. What a great idea!

Ever since she followed the Savings Wizard's advice, Anna is now a lucky young girl because she knows how to save, plan, use her savings and even have a budget.

\section{After reading the story, ask the group:}

What was the wizard's advice to Ana for helping her use her money properly?

$$
\text { Why is it good or bad advice? }
$$

How do you think the value of responsibility relates to the habit of saving money?

When is it easy to save money?

When is it difficult to save money?

\section{Theory and definition}

On the flipchart, write the word "savings" and then options of places where it is possible to save money. Read and discuss the following information:

What options for saving money exist in the community and municipality? 
Banks, credit unions, cuchubales (gatherings for money saving), at home.

What would you like to do with the money you save?

How much do you think you can save in a month?

How and where do you keep your savings?

Why should we save money? What should we save money for?

To pay for emergency expenses; to invest our money in something that can benefit us in the mid- and long-term; for decision making so that lack of money is not an obstacle for what we want to do.

Ask them to say words in native language that are synonyms of "Savings" and write them on the flipchart.

\section{Application in daily life}

Tell the participants:

Challenges and difficulties test our ability to make decisions and look after our savings. Unexpected events, like an illness, a death of a family member or losing one's job, can put us in critical situations where we need to react quickly. If we have not planned those events, we do whatever we can to face these situations and, sometimes, the pressure of such moments can cause us to make wrong decisions. When we have savings, we can anticipate what we want to do. In order to save money, it is necessary to reduce expenses and increase our income.

Let's pretend that each one of you managed to save some money. Although you had to make some sacrifices to save a little money every month, it paid off because you already thought about where you will invest it and you hope that sometime later you will have more money available. Something happens in your life, your family or your friends that requires having easy and fast money to solve the problem. What would you do? You are going to discuss it in groups.

Form two groups and hand each group a card with one of the following stories. Each group must read the card and discuss what the young girl is being asked to do with her savings, who benefits if the young girl gives her savings, and how would it affect the girl if she gives her savings. After the discussion, the group must decide what the girl should do-whether to give or not give her savings- and to explain how, by writing their own ending to the story.
Each group presents their story by doing a skit, storytelling, a drawing, a song, a comic, etc.

Give each girl a worksheet so that they can organize themselves and visit the community savings group, the nearest bank or other saving options. Give them time during the next session to share their answers.

\section{Story 1: THE BOYFRIEND}

Martha is 19 years old and in order to study at the Institute, she moved to town to live with some relatives. They have given her a place to stay in their house, but they do not give her spending money. During the week, she works doing embroideries to earn some money and pay for all her expenses. Up to now, she has saved $Q$ 300. She is very disciplined with her savings, because she knows that she does not want to live with her relatives forever and maybe, after finishing high school, she can set up a beauty salon.

Her boyfriend, Samuel, is a big dreamer. He wants to meet up with his cousin who lives in Chicago and work over there to make money and come back to marry Martha. He thinks that with the money Martha has saved, he would have enough money to go for a year. He is certain that he can make enough money so both of them can move in to a place of their own.

She began to consider listening to him and give him the $Q 300.00$ so he can go to the US and work there, while she waits for him in her town. What do you think Martha should do?

\section{Story 2: THE PARENTS}

Olga is 16 years old and lives with her parents and her younger brother and sister. She earns a little bit of money by helping her aunt at the market stand on Saturdays. Her dream is to take a computer class. She has done the math and concluded that she needs to save her income for 1 year in order to have enough money to enroll in the course and buy the materials.

Her father likes to play cards. Whenever he wins, he likes to brag about his success and gives his children a little extra money for lunch. But when he loses, her family cannot cover all their expenses. Olga's mother wants to prepare a special meal for Olga's brother's birthday, who loves meat. But, Olga's mother is short on cash and demands Q. 100.00, which is nearly half of her savings.

Both of Olga's parents think that adults must control finances because they are in a better position to balance the family's needs. What is Olga going to do? 


\section{Saving Options Consultation}

Visit the nearby institutions, persons and/or banks where you can deposit your savings and ask:

1. How much money is needed in order to open the savings account?

2. What are the requirements to open a saving account?

3. What are the benefits of having one?

4. How much is paid in order to keep my savings there?

Write the information of each option in the following chart:

\begin{tabular}{|l|l|l|l|l|}
\hline Option & $\begin{array}{l}\text { How much money } \\
\text { is needed in order } \\
\text { to open the savings } \\
\text { account? }\end{array}$ & $\begin{array}{l}\text { What are the } \\
\text { requirements for } \\
\text { opening a savings } \\
\text { account? }\end{array}$ & $\begin{array}{l}\text { What are the } \\
\text { benefits of having } \\
\text { one? }\end{array}$ & $\begin{array}{l}\text { How much is paid } \\
\text { in order to keep my } \\
\text { savings there? }\end{array}$ \\
\hline 1. & & & & \\
\hline 2. & & & & \\
\hline 3. & & & \\
\hline
\end{tabular}




\section{4) Building my life: job options}

OBJECTIVES
By the end of this session, participants
will have:
- Reflected about the purpose of
working.
- Identified violent scenarios among
the labor market options and the
domestic space.
- Numbered the job options available
in their community.
- Known how to manage the money
they will get for working.

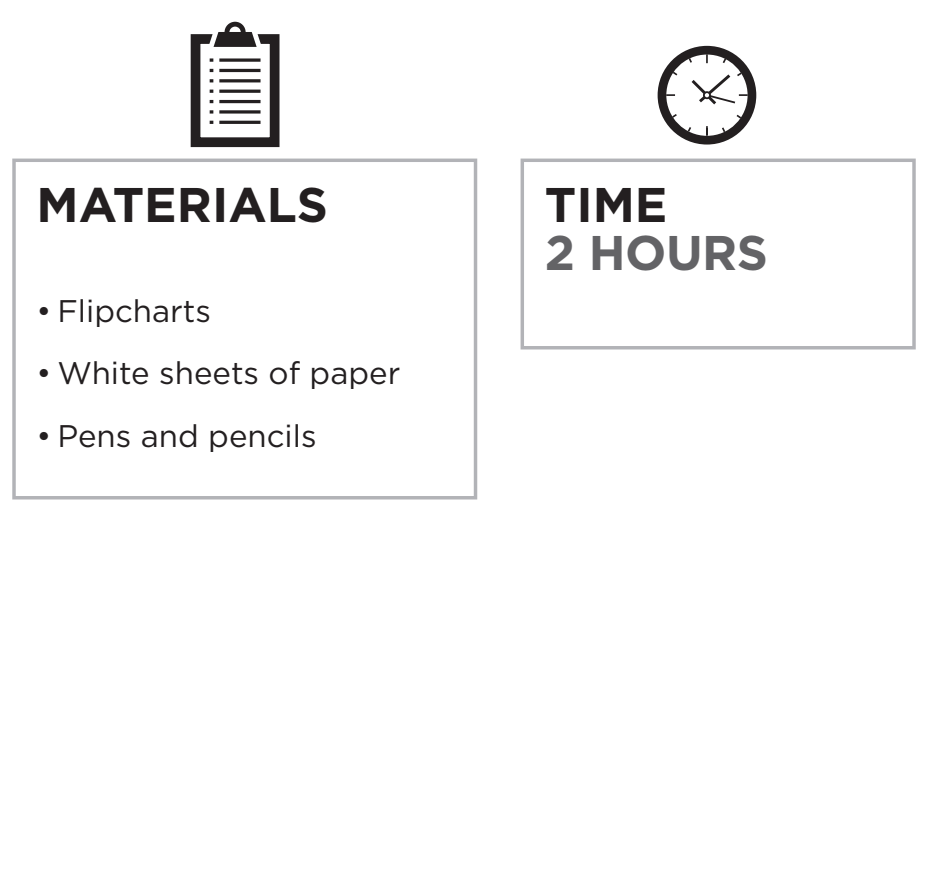

KEY CONCEPTS
Work: The effort that is done in order
to produce or to get a payment that
allows satisfying needs and desires.
Salary: Product or monetary payment
for the work done.
Violence: To cause physical,
emotional or psychological damage
to a person. Limiting a persons'
opportunities for growth and
fulfillment is also a kind of violence.




\section{Welcame}

Welcome the participants and take attendance. Share with them that today they will think about the future and what job opportunities they will have. Play charades so they start thinking of their job interests and possibilities.

\section{Topic introduction}

Ask the participants to define "work," share some of the jobs that they do and list the job options that they will have in their community. You can encourage them to share details about their working conditions (schedule, location, who they work for, what they do, benefits) and what they like and do not like about their job. Write down their answers on a flipchart as a brainstorm.

\section{Theory and definition}

Play the "asking round". They have to make two circles, one on the inside of the other facing their fellow group members. Ask them to walk in the opposite direction and when you say STOP they have to stop and listen to the question and discuss it with the partner they have in front. Use the following questions, one for each round:

How do you find a job in this community?

What job options can you find? What benefits do those options have?

Why do the people work so much in this community?

What is the work done in this community?

What work do the women in this community do and get a payment for? What work do the women in this community do and NOT get a payment for?

What are the violent risks that you can find in the different jobs?

The type of job that we select is a very personal decision. The job helps us to "earn a living" which is what helps us "build a life". We have to take into account our personal values and talents to make sure that we will be happy in the job that we get. Also jobs should help us grow intellectually and emotionally.

Give girls sheets of paper and ask them to draw themselves older and "making a living". Give a time for them to think and invite volunteers to share.

\section{Application in daily life}

Ask them to work in couples on "My job options" worksheet. When they finish they will share their with the rest of the group.

\begin{tabular}{|l|l|l|l|}
\hline Job & Requires that & $\begin{array}{c}\text { It offers me } \\
\text { development } \\
\text { in... }\end{array}$ & Risks \\
\hline & & & \\
\hline & & & \\
\hline & & & \\
\hline & & & \\
& & & \\
& & & \\
\hline
\end{tabular}




\section{5) I express myself assertively}

OBJECTIVES
By the end of this session, participants
will have:
- Practiced expressing themselves
assertively.
- Formulated assertive answers in the
face of daily situations that affect
their human rights.
- Discussed possible consequences
and reactions of using assertive
communication with different people
in their community.
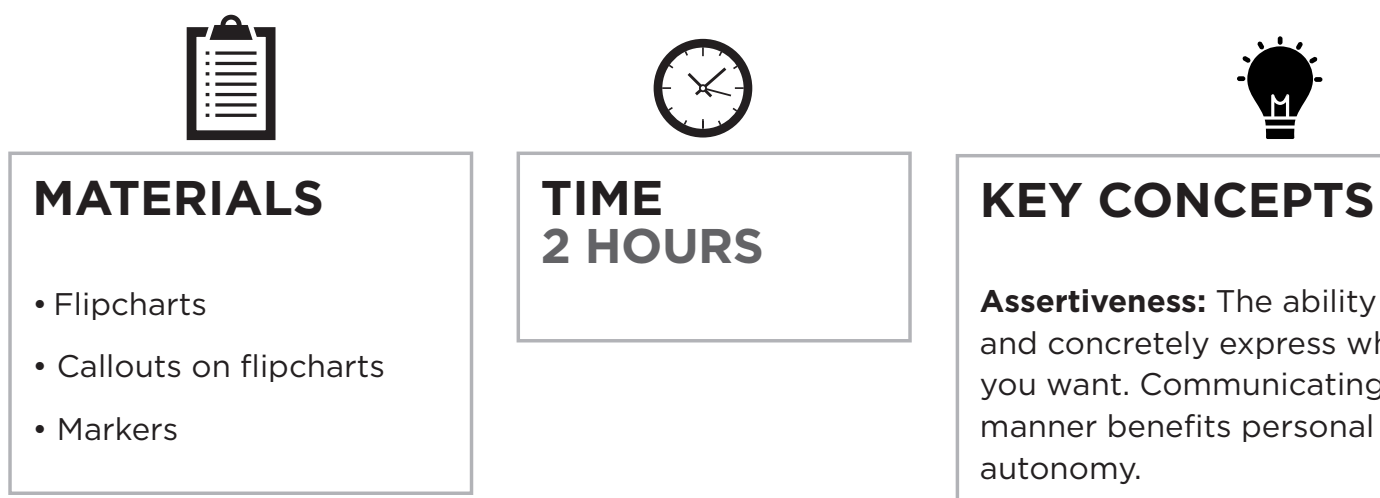

Assertiveness: The ability to clearly and concretely express what you want. Communicating in this manner benefits personal safety and autonomy. 


\section{Welcame}

Welcome the participants and take attendance. Share with them that today they will learn ways to communicate and see how assertiveness helps show everyone else that we are sure about what we are saying and what we want.

\section{Topic introduction}

5 Share with the participantes the story of the girl leader.

The girl leader gets nervous every time she wants to say something, even though she knows that she has to look into the eyes and faces of people when she talks and that she has to have a calm tone of voice. She also knows that she has to say things that are important for her. However, the other people do not pay attention to her even though she is a leader.

The girl leader knows what to do to be assertive, but when she talks with her parents to ask for permission to go out, she is not clear and they end up fighting.

Draw the following callouts in large writing and show them to the participants. Divide the participants into two groups one group reads the script of the girl leader and the other reads the answer.

Girl leader: I want to go out. You never let me go out.

Daughter, you always go out. You go out to work in the field; you go to the market with your mother

Let us see what happens when she talks with her best friend. She feels lonely because she wants her friend to call her more often.

\section{Girl leader: you never call me!}

I never call you? What do you mean I never call? We are talking on the phone right now.

Let us see what happens when she talks with her boyfriend. She is sad because he doesn't listen to her when she talks.

Girl leader: you don't care about me anymore.
Let us see what happens to her when she talks with her aunt, who's yelling at her.

\section{Girl leader: Stop yelling at me!}

I am your aunt and I can yell if I want to.

Ask the participants:

What type of communication did the girl leader use?

How did she make the others feel when she talked to them?

In how many cases did she solve her problems?

In the conversations, how did she say what she expects from the other person? How would you advise her to speak about her feelings in each case?

Is there something she can improve in the way she talks or communicates?

\section{Theory and definition}

Invite the participants to think of other ways to communicate what the girl leader wanted to say and change what she says in each callout.

5 Say to the participants:

When we talk and communicate, we do not always have to say YOU, YOU and YOU. We have to say what we would like the other person to do.

For example, she can tell the aunt, "Aunt, I would like it if you speak calmly to me, please." This way the aunt would understand exactly what the girl leader wants from her and does not feel that the girl leader is trying to order her.

Let participants read the definition of assertiveness and think of examples of assertive communication amongst them and their families. Encourage the group to change the phrases used by the girl leader into examples of assertive communication. 


\section{Application in daily life}

In groups of three girls will prepare a skit to present assertive communication strategies they can use in difficult situations. Assign one of the following suggestions to each group.

- A friend asks if she can copy from you in an exam.

- You need to ask for your parent's permission that you know is really hard to get.

- Negotiate with your dad because you want to stay in school.

- Your boyfriend invites you to a place where there are no people and you can be alone in the darkness with a boy.

- You have been told that you cannot participate because you are women and that you will be better off staying at home.

- You don't want to have any more kids but your life partner insists that you do. 


\section{6) I recognize when and where I am in danger}

OBJECTIVES
By the end of this session, participants
will have:
• Identified different types of
dangerous situations.
- Created strategies to avoid the risks
they face.
- Recognized that the decisions they
make without thinking could carry
more risks.

MATERIALS
-I make decisions in
order to get out of
dangerous situations"
worksheet
- Stories
- Flipchart with questions
- Poster with the 7 steps
to make decisions

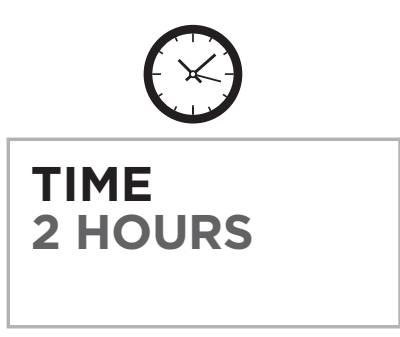
ability to analyze what is happening and think about what is best for them and the community. Based on that, women see their options and choose the one that will have better results in the short- and long- term.

Alternative: The option between two or more possible actions and decisions. 


\section{Welcame}

Welcome the participants and take attendance. Share that today they are going to read several stories and help the main characters identify risks and make the best possible decisions. Identifying risks and making decisions to prevent risky situations is something that you can practice every day.

\section{Topic introduction}

Form 5 groups and give each group one of the stories. Ask them to read the story and discuss in their group the following questions. Have the questions previously written on a flipchart:

\section{What dangers are the characters facing?} (Family, friends, work)

What work are they carrying out? Are any of their rights being violated or threatened?

Ask each group to share their story and answers to the questions. Promote the dialogue in the whole group.

Some questions that can enhance dialogue:

Do you know anyone who has worked in situations like these?

Why do they accept dangerous situations?

What can happen to the people who stay in dangerous jobs?

Why do some women stay in dangerous relationships that are risky for them and their child?

If a husband is violent, should the woman stay home just to keep the family together?

Will the kids be alright living in a violent environment?

How can they make decisions to improve the situation and keep it from becoming even more dangerous?

Write the answers down on the flipchart with the title WARNING and place it in a visible place to create awareness of situations that are dangerous for them in their community.

\section{Theory and definition \\ Read the key concepts together and then say:}

Many people have dangerous jobs because they think that is the only option they have. However, if a job is dangerous, instead of being helpful for the person, the job makes the situation even worse. When facing problems, it is very important to think about the alternatives we have, and what people and institutions can help us.

Why is learning to make decisions an important tool for preventing dangers we may face in our community or outside our community?

Read with the adolescent girls the seven steps for making a good decision that you brought written on a poster. Read with them the story No.1, Griselda's case, and then practice the seven steps.

\section{Aprlication in daily life}

Make groups of three friends. Give them the worksheet "I make decisions to get out of dangerous situations". Invite the participants to choose a situation they have to confront and comment on why it's dangerous for them. Once they have it, they have to practice the seven steps to reach a decision that can help them protect themselves.

At the end ask some groups to share their results. 


\section{Seven Steps for Making a Good Decision}

1. Identify your goals and the values you wish to respect.

2. Make a list of all possible alternatives available.

3. For each alternative, identify the risks and advantages it offers. Compare it with your goals and values to rule out those that are contradictory.

4. Look for more information on the alternatives that you agree with the most.

5. Consult your ideas and feelings with a person who has experience with the topic and can give you good advice.

6. Review your alternatives again with the new information and advice you have received.

7. List the steps for following the alternative you have chosen. Make sure those steps will enable you to reach your goal and respect the values you set at the beginning. Share your decision with the person who gave you advice and the people close to you and who care about you.

\section{Story 1}

For Griselda, her house is a nightmare and work is even worse. She's been working for 9 years harvesting strawberries. She started when she was six, when her mother would take her to work. She remembered watching children go to school, but she could not go. Many times, she tried telling her mother to take her to school, but Mrs. Josefa, being so worrisome and nervous, never let Griselda be by herself. Now, that Griselda is 15 years old, she understands her mother. Now, her mother lives with a man who yells at her all the time and demands her to cook for him and do whatever he orders. Also, the man is forcing her to marry him, but she does not want to. To make matters worse, the strawberry farm will not hire her mother because she is too old, and since she never went to school, she does not have a job to provide for her family. One day, Griselda was very angry at her boyfriend because he went out with another girl. When she saw her step-father go in the house and start yelling for his food, she built up the courage and told him that there was no food for a drunken man. The man got so furious and hit Griselda. That moment led Griselda to leave her house and now she is living on the streets.

\section{Story 2}

Zoila returns home very tired. After working for 12 hours, her hands hurt so much from baking all day that she can barely open the door. She has been saving some money and knows that she can stop working at the bakery and start selling handcrafts with her sister. But, the owner tells her that she has to continue working to pay her family's debt. That's when Zoila started working. Her father took her to work to pay off his debt. She barely remembers the debt and does not even know how much her family owes. She had asked her boss to check the numbers, because she thinks that after working for him for one year and getting only half a salary, the debt must be paid off by now. Eventually, Zoila decides to go to bed, because in the end she is going to have to go to work tomorrow anyway and she will not even get permission to go to the Health Center to have her hands checked.

\section{Story 3}

Angela is 17 years old, and her mother is sick and in need of medicine. That' is why Angela decided to go to the city to find a job cleaning houses. Luckily, she found a job fast at a house where they let her sleep and eat. At the end of the month, she will be able to send most of her salary to her mother. There is just one thing that is bothering her: the house owner's son keeps touching her. One time, Angela told the owner what was happening, but the son denied everything to his mother. Angela decided to continue working in that house, so she can help her mother, but she is afraid.

\section{Story 4}

Perla works at a farm in Alta Verapaz where she harvests cardamom. She is pregnant and her belly is starting to show, but she hides it because she is afraid that she will not be asked to work at the farm again if they find out.

This morning, Perla is feeling bad and thinks that there is something wrong in her belly, but still she keeps on working in the field. One of her coworkers saw her loose her balance and turn pale. She helped her to sit down. It was a relief for her to find a friend who helped her and take a brief break. She drank some water and rested under the shade. Suddenly, she heard a truck engine in the distance... It is the farmer's truck! "Here comes the boss!" Perla heard the rest of the workers yell. She felt her heart drop to the floor. And out of nowhere, she pulled herself up and pretended she was doing alright and continued working so the boss would not notice. 


\section{Story 5}

The Catam sisters live in San Marcos. The eldest is 15 years old and the youngest is 6 , and there are two other girls between ages 8 and 10 . Their family lets them go to school during the week, but on weekends they have to collect firewood. It is a hard and exhausting job. Their arms and back are tired from picking up and carrying the firewood from one place to another. Elbia, the eldest sister, has been working for so many years that she started to notice her back bending. She worries for her younger sisters, and she is trying to teach them the best way to carry firewood. They often work until very late in the evening deep in the forest gathering wood. She has to take care of her three sisters. Although they have wood and machetes to defend themselves, between the forest animals, the evildoers and the darkness, it is not an easy task to protect them. Tonight, Elbia feels particularly fearful. She heard that some young boys from the community want to scare her in the forest by sunset. She knows that though most of the young boys in the community are nice, these boys in particular are not. The father of one of these boys owns a business and he is forcing her father into working for him. After thinking and thinking about what to do, and how to protect her sisters and herself, Elbia feels like she is all alone. She does not want to worry her mother and doesn't have anyone she can go to for help. She ends up calling her sisters and praying for protection on their way to the forest. 
'GIRLS CREATING OPPORTUNITIES FOR A BRIGHTER TOMORROW' PROGRAM INTEGRATED CURRICULUM GUIDE

\section{Make Decisions to Stay Out of Dangerous Situations}

What dangerous situation are we facing?

Our decision to prevent the danger 


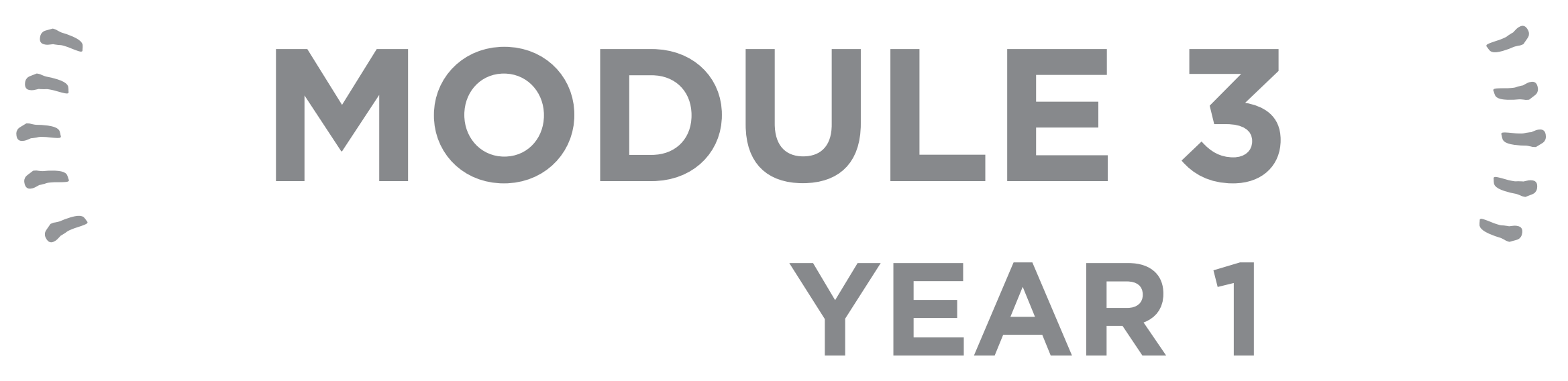




\section{MODULE 3}

\section{YEAR 1}

This module closes the first year of work with the Girls Creating Opportunities for a Brighter Tomorrow ${ }^{\circledast}$ Curriculum Guide. During this period, it is very important that the girls and adolescent girls remember and use the knowledge and skills they have developed to strengthen their decision-making skills. To support the girls in their transition to adolescence, they will start topics of sexuality including changes to the body, hygiene, feelings towards themselves and what respectful relationships look like. They affirm themselves as women with the capacity and the right to make free and informed decisions about their lives. Also, this period introduces the concept of sisterhood as a new way in which women can relate. They recognize that they share challenges and that instead of competing against each other, they can become allies.

\section{Group ages 8 to 12}

3.1 Sexual and reproductive health: Girls' health and our body

3.2 Sexual and reproductive health: Changes in our body as we grow

3.3 Sexual and reproductive health: The menstrual cycle

3.4 Gender: I am a girl and I can!

3.5 Gender: My girlfriends and I have a lot in common

\section{Group ages 13 to 17}

3.1 Sexual and reproductive health: Sexual health and reproductive health

3.2 Sexual and reproductive health: What are our sexual organs like?

3.3 Sexual and reproductive health: Body changes during puberty and the menstrual cycle

3.4 Gender: What is it like to be a woman? How were we taught to be women?

3.5 Gender: Sisterhood: A new way for women to relate to each other

3.6 Personal strengthening: I respect dignity when I communicate 


\section{1) Health and hygiene}

\begin{tabular}{|c|c|c|c|}
\hline $\begin{array}{l}\text { OBJECTIVES } \\
\text { By the end of this session, participants } \\
\text { will have: } \\
\text { - Recognized the parts of their body } \\
\text { by the scientific names. } \\
\text { - Named different ways to take care of } \\
\text { their body's health. } \\
\text { - Identified their sexual organs. } \\
\text { - Identified people in their community } \\
\text { that take care of them and respect } \\
\text { them. } \\
\text { - Mentioned hygiene habits. }\end{array}$ & $\begin{array}{l}\text { MATERIALS } \\
\text { - Puzzle of girl's body } \\
\text { - Silhouettes of a boy and } \\
\text { a girl } \\
\text { - Picture of a healthy girl } \\
\text { and a sick girl }\end{array}$ & $\begin{array}{l}\text { TIME } \\
2 \text { HOURS }\end{array}$ & $\begin{array}{l}\text { KEY CONCEPTS } \\
\text { Conditions for a girl's health: } \\
\text { - A healthy girl not only enjoys good } \\
\text { health, but she is happy too. } \\
\text { - She likes to play, study and feels } \\
\text { good and loved. } \\
\text { - In order to achieve this, girls need: } \\
\text { to eat healthy, drink potable water, } \\
\text { exercise, rest, play, and be cared for } \\
\text { by their family and community. } \\
\text { Female sexual organs: } \\
\text { - The organs that girls and women } \\
\text { have in their bodies. } \\
\text { - They help in the growing process } \\
\text { and they differentiate girls from } \\
\text { boys. }\end{array}$ \\
\hline
\end{tabular}




\section{Welcome}

Welcome the participants and take attendance. Invite them to play "Simons says" with their entire body. Explain that you are going to tell them the movements they have to do and follow and that you will always start by saying "Simons says..." They must listen carefully because when you do not say "Simon says" they must stay still without moving. Make sure you include all the body parts for the activity. Some suggestions are:

"Simon says jump high lifting your feet in the air"

"Simon says move your hands like corn in the sky"

"Simons says move your hips like water in a river"

"Simon says move your heads like a chicken"

"Simon says bend your knees in order to touch the ground with your hands" "Simon says walk like a rooster, with your breast to the front"

"Simon says walk backwards moving your gluteus"

"Simon says touch a friend's shoulder"

Keep playing using "Simon says" and instructions that do not begin with "Simon says".

\section{At the end of the game ask:}

\section{How do you feel?}

Name the parts of the body that you used?

What activities do you use your bodies for everyday?

\section{Topic introduction}

Give the participants pieces of a puzzle. Some will have pieces with the body parts and others will have pieces with the name of the body parts. Ask them to put the puzzle together. Once the puzzle is done, they have to identify and say the names of the parts of the body. The puzzle will have to include the following parts:

$\begin{array}{llll}\text { - Head } & \text { - } & \text { Shoulders } \\ \text { - Hair } & \text { - } & \text { Hands } \\ \text { - Neck } & \text { - } & \text { Arms }\end{array}$

$\begin{array}{llll}\text { - } & \text { Breasts } & \text { - } & \text { Thighs } \\ \text { - Waist } & \text { - } & \text { Gluteus } \\ \text { - Hips } & \text { - } & \text { Knees } \\ \text { - Vulva } & \text { - } & \text { Feet }\end{array}$

\section{Theory and definition}

Next to the puzzle put the drawing of a boy's and a girl's interior

\section{Ask the participants:}

\section{What similarities can you see in both bodies?}

What differences?

Which one is a girl's body?

Which one is a boy's?

Emphasizing the girl's body, circle the area of the female sexual organs. Put signs by each one of the organs telling the girls their functions.

Uterus: A pear-shaped organ the size of a fist located in the pelvic region. Here is where the fetus develops during pregnancy.

Fallopian tubes: Two long tubes on each side of the uterus. They connect the uterus to the ovaries. The endings near the ovaries are shaped like a flower. The egg travels through these tubes into the uterus.

Ovaries: Two oval shaped organs located at the end of the Fallopian tubes. They store the eggs as well as produce and secrete female hormones.

Vagina: Channel that extends from the vulva to the uterus. It is a very elastic muscular organ that can stretch during sexual intercourse or birth

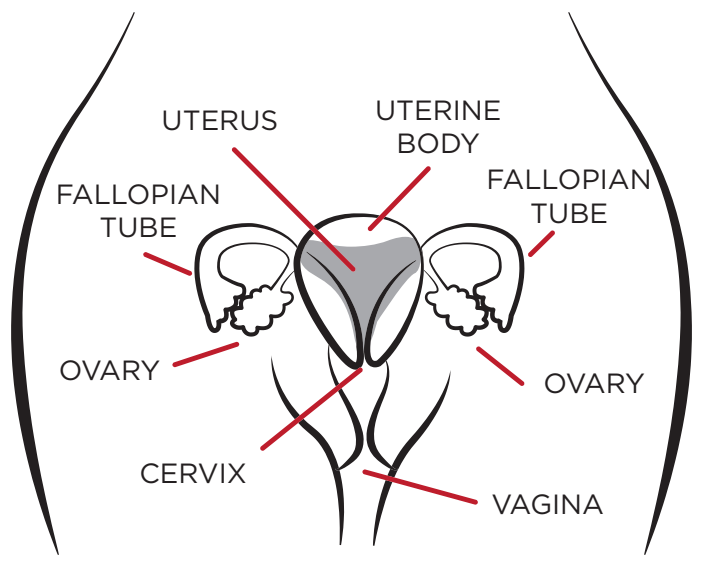


Next ask:

Where you familiar with these organs?

How are they like the rest of our body organs?

Which girls have these organs?

What have you heard about these organs and what are they for?

Do these organs help us or harm us?

To finish the activity, say to the participants:

Women can feel comfortable knowing and talking about their bodies in order to take care of them. We are learning to talk about our bodies and taking care of our hygiene in order to be healthy. All organs of our body help us grow, develop and be happy. Now we are going to see how to take care of our bodies.

Show participants a picture of a healthy girl and a picture of an unhealthy girl. Ask the participants to find the differences between both pictures. Write down the healthy girls' characteristics on the flipchart. You can use the following table as references characteristics for both healthy and unhealthy girls.

\begin{tabular}{|l|l|}
\hline \multicolumn{1}{|c|}{ Healthy Girls } & \multicolumn{1}{c|}{ Unhealthy Girls } \\
\hline Correct weight & Overweight or extremely thin \\
\hline Healthy skin color & $\begin{array}{l}\text { Skin with spots and welts or skin } \\
\text { infections }\end{array}$ \\
\hline Happy, relates with other girls & $\begin{array}{l}\text { Sad, lonely, doesn't relate with other } \\
\text { girls }\end{array}$ \\
\hline Developed height & Limited height \\
\hline Complete and clean teeth & Incomplete and dirty teeth \\
\hline Opened and bright eyes & $\begin{array}{l}\text { Dull eyes and dark circles around the } \\
\text { eyes }\end{array}$ \\
\hline Thick and colorful hair & $\begin{array}{l}\text { Brittle and thinning hair with faded } \\
\text { color }\end{array}$ \\
\hline Good respiration & Cough or difficulty breathing \\
\hline Learns in school & Skin infections or rash \\
\hline
\end{tabular}

Ask the group:

What actions cause a girl to be healthy and happy?

- $\quad$ Eating clean and varied food; eating less junk food; eating more fruits and proteins, herbs, meats and vegetables.

- $\quad$ Resting plenty

- Staying clean

- Exercising

- $\quad$ Playing

- Using water and soap to wash their body including their vulva.

- Not putting anything inside the vagina

- Avoiding getting hit in the genital area

- $\quad$ Not letting others touch your body when you don't want it

- Changing underwear every day

- Feel loved and special

- Having friends and people they can trust

\section{Application in daily life}

At the end, remind them that their health is their greatest treasure, which includes their body as well as their emotions, intelligence, and their dreams. This treasure is theirs. No one else can touch or use their body, nor can people make them feel uncomfortable.

Hand out the "Girls' Health" worksheet and have them draw themselves on it. They have to write the names of the people that love, respect and protect them as a protective circle. Outside the circle they have to write the things that put them at risk. 
'GIRLS CREATING OPPORTUNITIES FOR A BRIGHTER TOMORROW' PROGRAM

INTEGRATED CURRICULUM GUIDE

\section{Girls' Health}




\section{2) changes in our body as we grow}

\begin{tabular}{|c|c|c|c|}
\hline $\begin{array}{l}\text { OBJECTIVES } \\
\text { By the end of this session, participants } \\
\text { will have: } \\
\text { - Understood that when girls grow, } \\
\text { their bodies and relationships change } \\
\text { and that is totally natural. } \\
\text { - Named some of the normal changes } \\
\text { in a girl's life when they become } \\
\text { adolescents. }\end{array}$ & $\begin{array}{l}\text { MATERIALS } \\
\text { - Markers } \\
\text { - Crayons } \\
\text { - Charades roles: Baby, } \\
\text { a girl who is starting to } \\
\text { walk, a girl on her first } \\
\text { day of school, a young } \\
\text { woman who finds a boy } \\
\text { she is attracted to, a } \\
\text { woman who enters high } \\
\text { school and a grown up } \\
\text { lady who is selling her } \\
\text { harvest. } \\
\text { - Flipcharts }\end{array}$ & $\begin{array}{l}\text { TIME } \\
2 \text { HOURS }\end{array}$ & $\begin{array}{l}\text { KEY CONCEPTS } \\
\text { Maturing: } \\
\text { It is a natural process that happens } \\
\text { during the lifetime of all live beings. } \\
\text { In people you can see changes in } \\
\text { their bodies, emotions, and in the way } \\
\text { girls and boys act when they become } \\
\text { adolescents. An important part of this } \\
\text { process is that the body is beginning } \\
\text { to prepare for reproduction. } \\
\text { Body changes: } \\
\text { Girl's body changes during puberty } \\
\text { include: } \\
\text { - Hair growth in the pubic area and } \\
\text { underarms } \\
\text { - Breasts growth } \\
\text { - Widening of the hips } \\
\text { - Menstruation } \\
\text { - Physical maturity to become } \\
\text { pregnant }\end{array}$ \\
\hline
\end{tabular}




\section{Welcame}

Welcome the participants and take attendance. Start the session by playing charades. Five volunteers will take a little paper that describes a stage in a girl's life. They have to act out the stage without talking. The rest of the participants will have to guess what is happening to the girl. Once they have guessed all of the stages, let the girls see the papers and ask them to put them in the sequence these stages really happen.

\section{Topic introduction}

Present participants with female silhouettes, from a little baby to an elderly woman (girl, adolescent, and women). Ask them to pass to the front and point on the drawings to the things that are similar between one silhouette and another. Encourage them to point out the most similarities they can find. Then circle differences between the female body at each stage.

When they finish, ask them:

What similarities/differences did you find?

What parts of the body change when we grow?

Besides the body, what other things change in a girl's life when she becomes an adolescent?

\section{Theory and definition}

In both women and men, body changes happen and along with changes in behavior, responsibilities and relationships. When a girl or boy reaches puberty the most evident changes happen, and it is important to know them because they mark the beginning of the reproductive stage of life.

The changing period of adolescence is called "puberty". These changes begin with the body, because the body is maturing and preparing itself for the reproductive phase.

Write the changes on a flipchart for the girls to see.
What changes in the body happen during puberty?

\section{Women}

- Hair growth in underarms, legs, pubic area and the external genital organs.

- Breast growth

- Hips widen

- $\quad$ Presence of menstruation

- Appearance of acne on face and body

\section{Application in daily life}

Tell the participants:

Along with the changes in the body, there are changes in behavior, relationships, jobs, activities, etc. Now, let's see these changes here in the community. Form four groups and each group has to act out one of the four stages of development without saying which one. Then, the rest of the participants have to guess which stage it is.

Comment on changes imposed by family, school, and other in the community and the effects these impositions have on their liberties and access to rights.

What advice do families five girls when the reach puberty?

Do girls have more freedom as they become older?

What new tasks are expected of an adolescent girl?

Is it the same for boys than for girls?

How are girls' rights limited at this stage?

What kind of information would be use full for all girls to have before the reach puberty? 
MENTOR STUDYING RESOURCE

What are the female sexual organs like?

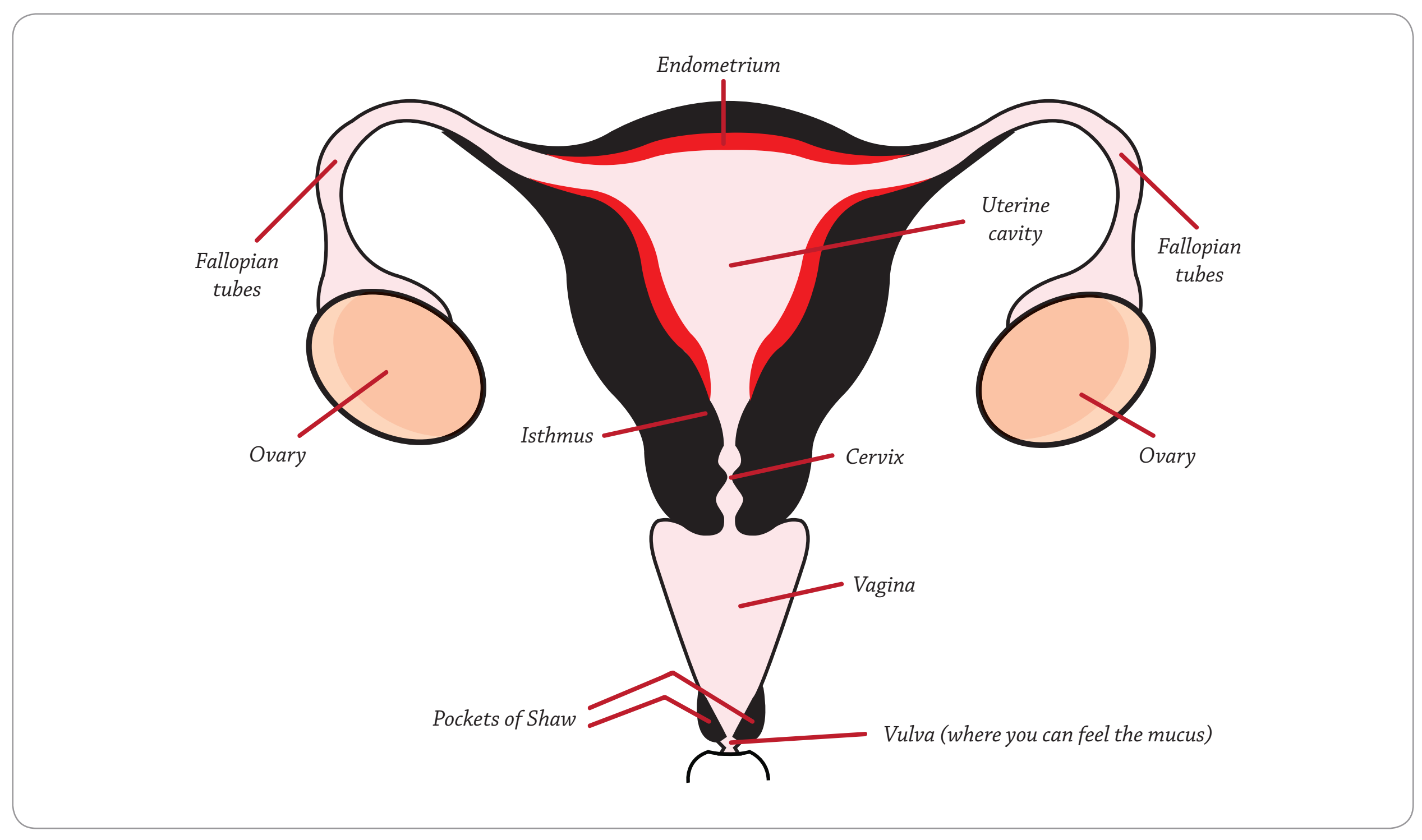




\section{3) The menstrual cycle}

OBJECTIVES
By the end of this session, participants
will have:
- Learned that the menstrual cycle is
totally natural and healthy.
- Learned basic hygiene practices to
use during the menstrual cycle.
- Identified myths and facts about the
menstrual cycle.

MATERIALS
- Poster of internal female
sexual organs
- Object to pass around as
a "hot potato"
- Markers
- Information sheets:
Hygiene Practices
- Worksheet
- Flipcharts
- Arrows and drawings of
an egg and blood drops
- Posters with the four
steps

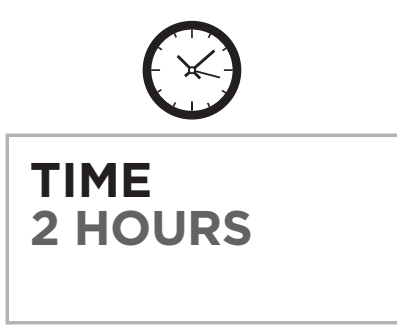

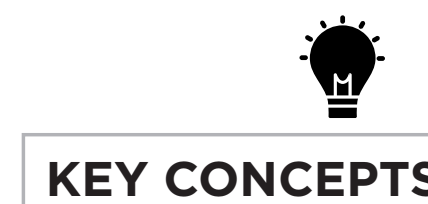

Menarche: The first menstruation.

Menstrual cycle: Hormonal cycle that produces menstruation.

Menstruation: The moment in which the body completes a menstrual cycle and eliminates the blood from the uterus. 


\section{Welcame}

Welcome the participants and take attendance. You can congratulate those who have had excellent attendance during this module and tell them to keep it up and encourage the rest to continue to come despite their difficulties.

Play hot potato to have participants share one thing she learned about her body, her life or her friends during her participation in the program. Play three rounds and then play three more rounds in which they have to mention things that they still want to learn about their bodies.

\section{Topic introduction}

Hang up different flip charts with several menstruation-related words on them throughout the room. Then ask the participants to go around to each one and write on them what they know about the topic. Include at least the following words: menstruation, menstrual cramps, sanitary pads (maxi pads), and fertility.

After a while, go through each word with the whole group, reading what they wrote, completing information and clearing up any misunderstandings.

Present a poster with women's internal sexual organs to explain the menstrual cycle. Tell the participants:

It is important to remember the names and functions of our sexual organs because that is where the menstrual cycle develops. We will play guess who? So I will give information about the organs, so you can guess which it is and point it out on the chart.

\section{Theory and definition}

Using the poster, arrows and small drawings of an egg and drops of blood, explain the menstrual cycle process as follows. You can also write the steps on a flipchart next to the sexual organs' drawings. Say:

a. Approximately every 28 days, the brain signals one of the ovaries to release an egg. This process is called "ovulation".

b. The egg travels through the Fallopian tube into the uterus.

C. While the egg is traveling very slowly through the Fallopian tube, the uterus prepares itself by forming a thick layer of blood.

d. If the egg is not fertilized, it disintegrates and the layer of blood in the uterus detaches little by little exiting the body. This is menstruation that lasts between 3 to 7 days, depending on the woman because all of bodies are different.

A girl's first menstruation is called MENARCHE. Menstruation is a sign that our body has matured and is preparing itself for reproduction. BUT, we do not have to start becoming moms when we have our first menstruation, this is a decision you can make voluntarily when you become older and are ready to be responsible for your children. Understanding our menstrual cycle is important for us to be able to take care of ourselves and also be careful with our personal hygiene.

Have participants read the information sheet for facts about important hygiene practices to have during menstruation days. Allow them time to ask all the questions they have and do your best to offer scientific information. If there is something you are not sure about consult a book or an expert on the topic. 


\section{Aprlication in daily life} their own first, and then go through each line together offering the correct solution and information.

\begin{tabular}{|l|l|}
\hline Is it true that...? & Answer \\
\hline Menstruation is a disease. & $\begin{array}{l}\text { False. Menstruation is natural and it happens to } \\
\text { every woman. }\end{array}$ \\
\hline $\begin{array}{l}\text { You should not go out during } \\
\text { menstruation. }\end{array}$ & $\begin{array}{l}\text { False. During menstruation, there is really nothing } \\
\text { a woman cannot do. She can go out for walks, } \\
\text { bathe, do exercises, and eat anything, go to mass. } \\
\text { She might feel a bit more tired than usual. }\end{array}$ \\
\hline $\begin{array}{l}\text { During menstruation, you have to shower } \\
\text { every day to stay clean and this doesn't } \\
\text { harm your body. }\end{array}$ & $\begin{array}{l}\text { True. During menstruation, the most important } \\
\text { thing to do is shower every day. }\end{array}$ \\
\hline $\begin{array}{l}\text { During menstruation, you must change } \\
\text { sanitary pads at least three times a day. }\end{array}$ & $\begin{array}{l}\text { True. To avoid bad odors and stay clean, the } \\
\text { sanitary pad must be changed at least three } \\
\text { times a day. }\end{array}$ \\
\hline $\begin{array}{l}\text { An adolescent girl can get pregnant } \\
\text { during the first time she has sexual } \\
\text { intercourse. }\end{array}$ & $\begin{array}{l}\text { True. Every time someone has sexual intercourse } \\
\text { there is a risk of becoming pregnant even if it the } \\
\text { first menstrual cycle she has had. }\end{array}$ \\
\hline
\end{tabular}


MY MENSTRUAL CYCLE

\section{Draw the four phases of the menstrual cycle}

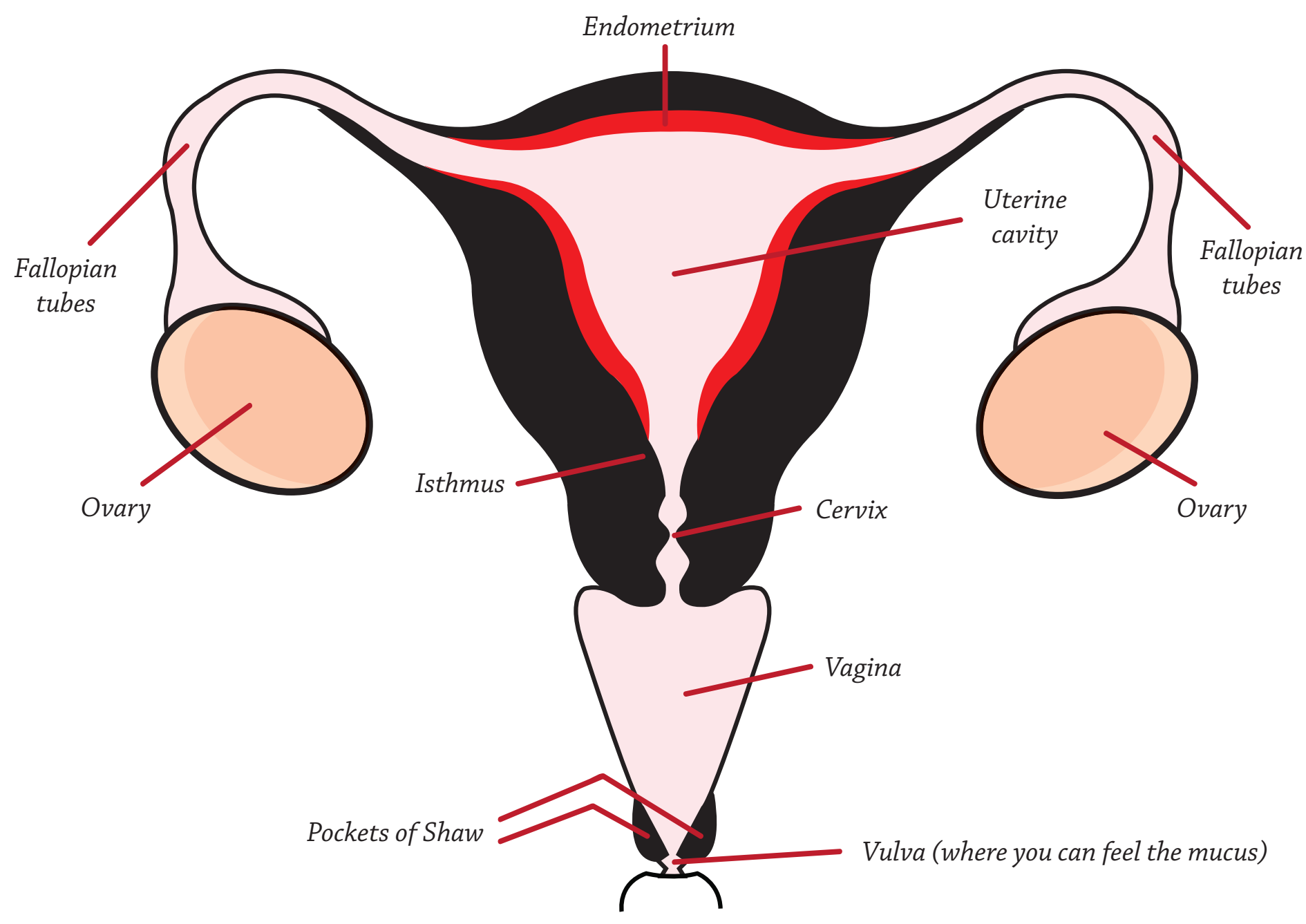




\section{IMPORTANT HYGIENE PRACTICES}

1. Use soap and water to wash the genital area every day.

2. Do not put anything inside the vagina.

3. Avoid getting hit in the genital area.

4. Do not let other people touch your body when you do not want them to.

5. Change underwear daily.

6. Exercise frequently.

7. When you have your menstruation, you have to change your sanitary pad at least three to four times a day, according to your need. 


\begin{tabular}{|l|l|}
\hline Is it true that...? & Answer \\
\hline Menstruation is a disease. & \\
\hline $\begin{array}{l}\text { You should not go out during } \\
\text { menstruation. }\end{array}$ & \\
\hline $\begin{array}{l}\text { During menstruation, you have to shower } \\
\text { every day to stay clean and this doesn't } \\
\text { harm your body. }\end{array}$ & \\
\hline $\begin{array}{l}\text { During menstruation, you must change } \\
\text { sanitary pads at least three times a day. }\end{array}$ & \\
\hline $\begin{array}{l}\text { An adolescent girl can get pregnant } \\
\text { during the first time she has sexual } \\
\text { intercourse. }\end{array}$ & \\
\hline
\end{tabular}




\section{4) I am a girl and I can!}

OBJECTIVES
By the end of this session, participants
will have:
- Identified behaviors imposed on
them for being girls.
- Identified customs and ideas
that limit girls' and women's
development.
- Thought about things that are not
considered womanly, but that they
like or call their attention and they
can try to do them.

MATERIALS
- Flipchart
- Markers
- Images of the bodies of a
girl and a boy
- Small poster with things
for girls and boys
- Flipchart with gender
roles

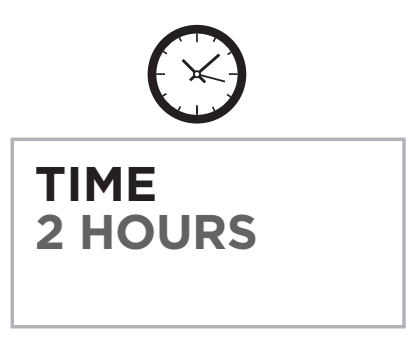

\section{KEY CONCEPTS}

Gender: Different traits and behaviors assigned to men and women by the community and family. Expectations and stereotypes of how women should be and how men should be.

Girls and boys are biologically different mainly in their reproductive organs, but are equal in other ways. However, the community teaches them to behave differently and has even made them think that there are things they can't do because they are girls or boys. The truth is that girls and boys can do the same things. 


\section{Welcame}

Welcome the participants and take attendance. Congratulate the girls for their achievements throughout the module, even if their attendance has not been perfect. This encourages them to continue to come. Share with them that today they are going to think and talk about themselves, about being girls, what they like about being girls, but also about limits set upon them for being girls.

\section{Topic introduction}

Show the participants the poster that has a drawing of the inside of a boy's body and a girl's body.

Ask:

\section{What do you see on the poster?}

What are the most visible differences between boys' and girls' anatomy? In what ways are we similar to boys? In what ways are we different?

Bring drawings of girl's and boy's clothes, as well as toys and other objects the size of the body drawings of a girl and a boy, so every girl can dress the pictures with the clothes in the corresponding body. You may include objects such as the following:

For the girl
Güipil
Skirt
Sash
Apron
Sandals
Comal
Doll
Flowers

\section{For the boy}

Shirt

Pants

Belt

Sport shoes

Socks

Cap

Soccer bal

Machete

Bicycle

\section{Theory and definition}

After the participants have pasted all the objects, ask them to spot the differences between girls and boys, and say:

What differences do you see now?

Are these differences present in us at the time of our birth?

When do we seem to start to look different from boys? What do families do to let the community know if it's a baby girl or boy.

\section{We are born with very similar bodies and the same capabilities.}

How does it come to be that there are so many differences between boys and girls?

Where do we learn these differences from?

Who says that girls like pink and flowers and that boys are strong, do not cry and like soccer?

There are few biological characteristics that differentiate and define a man from a woman... such as the ability to breastfeed, become pregnant or be a father. These define the sex of a person and will never change. Most of the characteristics are determined and decided upon by society. The way to be a man or a woman, how to act like a woman, her responsibilities and roles, are called Gender roles. These change over time and from one society to another, even from woman to woman.

Unfortunately, the ideas our society teach us on how women should act make us think we are weak, think that we cannot do certain things, and that we only serve the house, children and husbands. Although all of this is not true, we accept it and live this way. In many cases, this has lead men to dominate and mistreat women and women accept this, until it becomes a custom and tradition. Some people have tried to change these ideas and to live and be different, only to find themselves in situations of violence and rejection by their family, society and community. 


\section{Application in daily life} girls and boys (if your community has different ones, change them to those that best depict your community). Ask the girls to form groups of three. Have them discuss amongst them if the idea is something that makes girls feel happy or sad. Depending on the answer, put a happy face or a sad face next to each phrase.

$\checkmark$ Women are week and fragile, they always have to be accompanied by a man that can take care of them and tell them what to do.

$\checkmark$ When girls become adolescents, they should not be alone on the streets.

$\checkmark$ Girls have to learn to be good wives and mothers, because that's what they were born to do.

$\checkmark$ Balls, books and cars are toys only for boys.

$\checkmark$ Dolls and tea sets are toys only for girls.

$\checkmark$ Girls don't need education because they are going to get married.

$\checkmark$ Boys inherit the land to support the family.

Invite girls to challenge these gender roles by stating different ones that make them feel happy. 


OBJECTIVES
By the end of this session, participants
will have:
- Identified characteristics, needs, joys
and sorrows they share with each
other.
- Thought about the way they should
relate to each other because they
have so many things in common.
- Worked with each other through
cooperative activities.
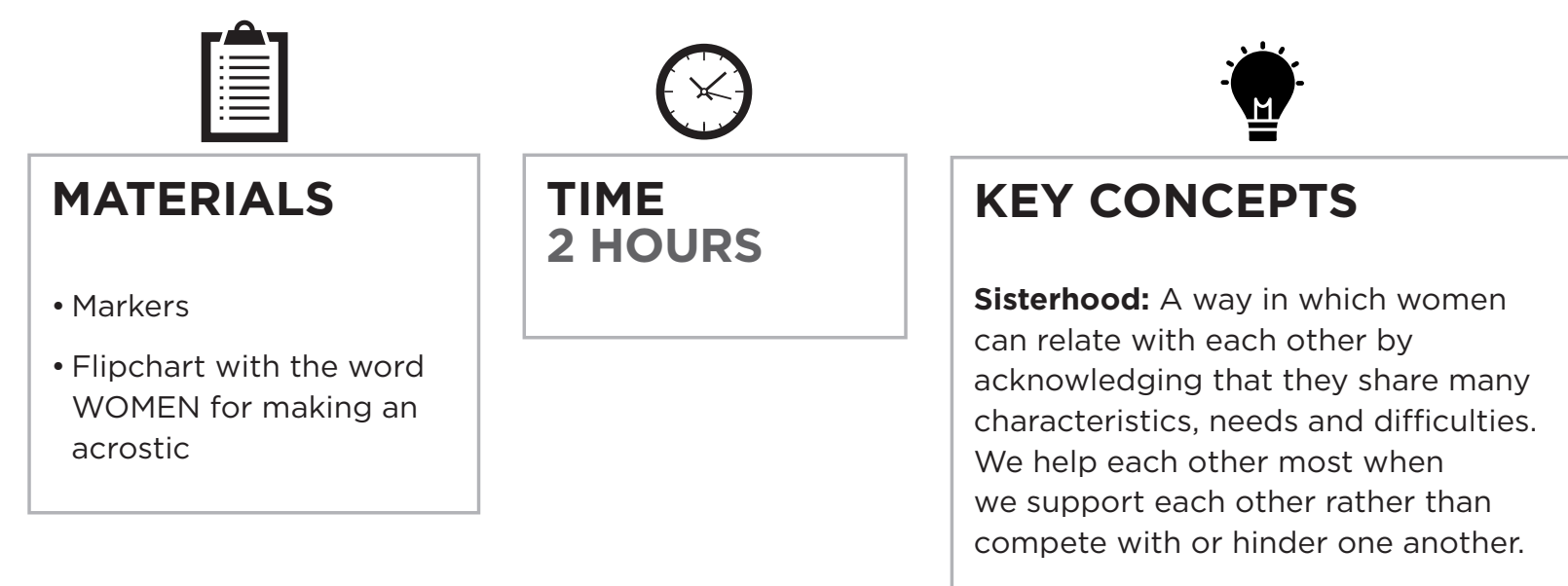


\section{Welcame}

Welcome the participants and take attendance. Mention the names of girls who you feel proud of because of their achievements this year. Avoid repeating those you have already mentioned and this time, mention those who have participated the least and need more support. Share with them that today they are going to talk about friends.

\section{Topic introduction}

Play "Bus passengers". You are going to ask them to form groups according to the amount of passengers that are in the bus, by telling the girls "There goes a bus with\# passengers", participants must group together. Between each round ask the following questions to answer amongst the groups each other:

Question 1: What do you like the most about your friends?

Question 2: What makes you feel very happy?

Question 3: What would you like to be when you grow up?

Question 4: How do you feel when you are not allowed to do something because you are a girl?

\section{Theory and definition}

After the exercise, have participants sit down in a circle and dialogue about their relationships with friends. Ask them:

What did you learn from your friends today?

What did you learn about the things you have in common?

How can you learn from your friends?

What type of relationship would you like to have with your friends?

What problems do you share with your friends and other women in the community? How can you unify your efforts in order to overcome these problems?

After discussing the questions, tell the participants:

Women have noticed that we have many things in common, good things as well as very difficult problems in our lives. Women could relate to each other based on friendship and sisterhood, if we stop competing against other women and stop criticizing one another. We share similar challenges and problems and thus could help and support one another to overcome these. This way of relating is known as SISTERHOOD. Instead of being several women divided and fighting each other, we can form a big group of women supporting each another. Whether we are objects of gossip or we are being told bad things, in these scenarios it is very important to believe in our worth and our respect.

Women's Acrostic. Hang up a poster that reads "WOMEN". Invite the participants to do an acrostic together. With each letter of the word "women," they should write a problem or challenge shared by the women in their community. To stimulate their ideas, you can brainstorm with them, ask the participants:
Teaching Tip

Acrostics are for strengthening a concept or description about something or someone. It gets people

thinking about the meaning of the word they are turning into an acrostic and it also invites them to expand their vocabulary. For example, an acrostic for the word SUN:

Shiny

Universal

eNtity
What troubles do share when facing problems?

\section{Application in daily life}

Play two cooperative games that make participants work as a team, communicate and have respect for each other. Ask them to suggest games the feel happy playing because they help and get helped by their peers. 


\section{1) Health in youth and motherhood}

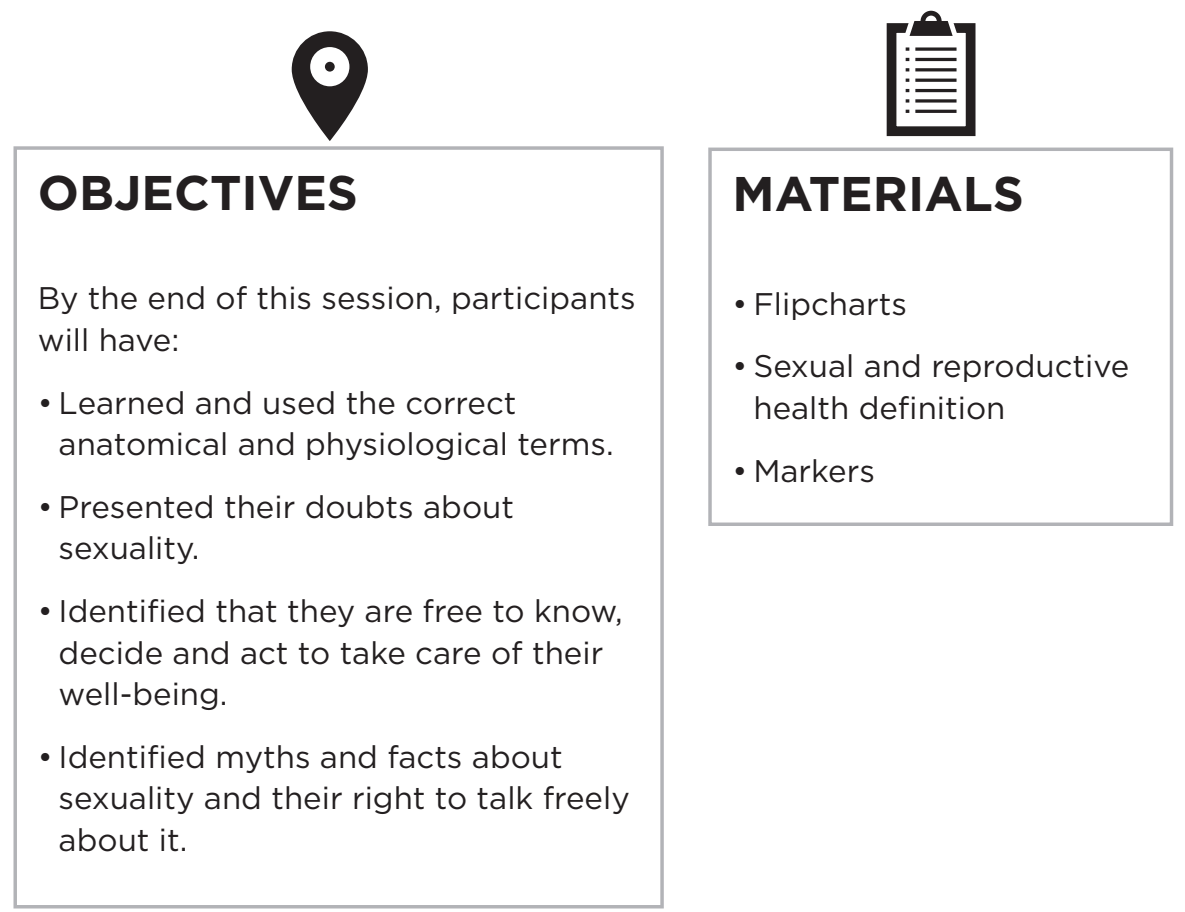

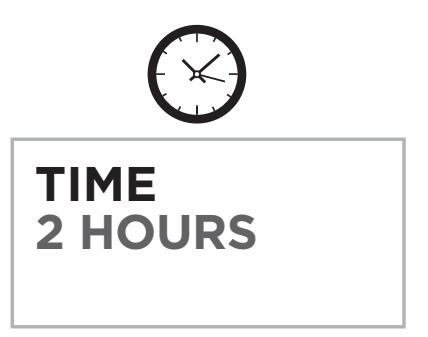
is a continuous process of physical, psychological and socio-cultural wellbeing related to sexuality. It is evidenced in the free and responsible expressions of sexual abilities that lead to personal and social wellbeing. In order to achieve and maintain sexual health, there must be recognition and protection of every person's sexual rights. (OPS, OMS, 2000).

Reproductive phase: Stage of development in which the human body has achieved certain maturity and can reproduce.

\section{Maternal mortality prevention:}

Actions that protect mothers from risky situations linked to motherhood. 


\section{Welcame}

Welcome the participants and take attendance. Tell them that today they need to have their tongues untangled so that they can talk about all the things our body does, and start by playing tongue twisters or 'jerigonza'.

\section{Topic introduction}

Ask them to form a circle, and give them time to talk about what it means in their community to be a girl and to turn into a young woman. Some questions you can use are:

What changes does a girl experience in this community when she stops being a little girl and becomes a young woman?

How does her life improve?

What new risks does she experience?

What fears have you had?

Do you know any case of a young girl whose health was affected because of the new activities she was required to do as a young woman?

Thank every girl for their participation, respect their comments and allow them to be honest and sincere without judging them. Do not scold them because of what they are saying. Try to be comprehensive and open to their experiences. At the end, emphasize the risky experiences that are given because the young girls start to have children or because they start actively having sexual intercourse.

\section{Theory and definition}

Write the concept of Sexual and Reproductive Health on a flipchart and read it to them. Then explain the following regarding Sexual and Reproductive Health.

Sexual and reproductive health education implies talking about how humans reproduce and the relationships between humans. This is a human right, because if you know about sexual and reproductive health you have more information and knowledge to make proper decisions in your relationships with other persons and about the life you want to have.

\section{Ask them:}

How is this definition related to what we talked about women in this community go through?

Ask them to form pairs with friends. Give each pair half a flipchart and ask them to draw how they feel towards learning about sexual and reproductive health. Under each drawing, they should make a list of questions on the topics that they would like to know regarding sexual and reproductive health. Emphasize that every feeling and every question they may have is normal and important. Collect flipcharts and hang them on a place where they all can see. Give participants time to see other groups' work, and then ask:

What feelings have been expressed?

How many questions did you read?

What have you learned about this topic?

What have you been told about sexuality in your homes? At school? At church? Why it is uncommon to give all the information to young people about their bodies and sexual health?

Why do you need information?

\section{Application in daily life}

Have participants write down on one flipchart all the arguments community members present as arguments against young people having information about their bodies. Some myths might be:

- It is a sin to talk about these topics.

- Once adolescent girls start to learn about these topics, they will go out looking for boyfriends to experiment things.

- $\quad$ Talking about sexuality creates curiosity and makes them want to try everything they have been told.

- It is a topic just for men. Women do not have to learn about this.

- $\quad$ Those who talk about it, have surely experienced something and are having random sexual encounters.

- Not every person is the same and so not everyone needs to talk about the topic.

- It is a family topic and it can only be discussed in the family when parents want to.

- It is best if they learn with their friends or their husbands. 
Let the group discuss these myths and identify what things are true and which are not. While they are working on this, hang (on a visible part of the room)

flipcharts with answers and arguments that explain why is it important to learn about sexuality, including:

- Our body is a wonderful gift and we should learn about it in order to be able to take care of and respect it.

- The information from TV, male and female friends, and word on the street is not always the truth; it can be confusing and can lead to serious mistakes.

- Being informed eliminates morbid fascinations and allows for a healthy and responsible attitude.

- Sexuality is a topic for both men and women; they both have sexuality.

- There is a lot of information about sexuality and sexual health available in schools, libraries, etc.

- Sometimes families do not have enough information and they need someone else to teach the topic with scientific data.

- Learning about sexuality means to be interested in learning more about the body and ways to relate.

- Learning about sexuality allows adolescent girls to be responsible for their decisions.

Read through the possible answers with the group and have them pair up each myth with an answer they can present. 


\section{2) What are our sexual organs like?}

OBJECTIVES
By the end of this session, participants
will have:
- Known the names and functions
of the internal and external female
sexual organs.
- Identified female sexual organs.
- Discussed why they have the right
to know about their body and how
it allows them to take care of their
health.

MATERIALS
- 4 puzzles of the external
and internal sexual
organs
- Flashcards with the
name and description
of each external sexual
organ
- Flipchart
- Markers
- Papers with answers to
myths Worksheet

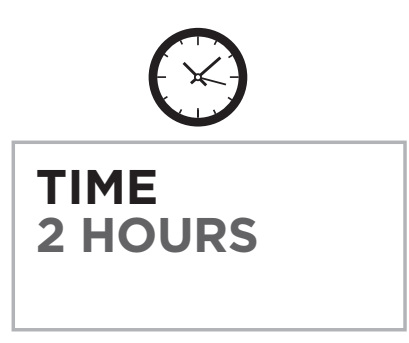

KEY CONCEPTS
External sexual organs: Group of
sexual organs located on the exterior
part of a woman's body.
Internal sexual organs: Group of
sexual organs located in the interior of
a woman's body.




\section{Welcame}

Welcome the participants and take attendance. Share with the participants that today they are going to learn about their bodies and they should start by hugging themselves and thanking their bodies for everything it does for them. You can ask them to tell you what their favorite body part is and why and then go ahead and hug herself.

\section{Topic intraduction}

Form 4 groups and give each group one puzzle for them assemble. Once they are done ask them to glue it on a flipchart and write the title "Female sexual organs". Before they glue it, you should check that it has been properly assembled.

Hand each group a bag of flashcards with the names of the sexual organs, and ask them to place each card over the organ it names.

\section{Theory and definition}

In the same groups, hand each participant a copy of the worksheet with a wom an's sexual organs and ask them to check if they have placed the organ cards in the correct location. If they placed a card in the incorrect organ, ask them to fix it. Then, have them tape the cards to the correct organ.

Next, ask them to come together. In front of the group, hang up a large poster with the images of the internal and external sexual organs. Ask for volunteers to come up front and place the labels of each sexual organ on the correct place and ask them to say the function of each organ they are labeling.

\section{Application in daily life}

Ask the participants:

Which organs are new and you did not know?

What are the sexual organs for?

Having babies, feeling pleasure, but also for a girl to develop into a woman and be healthy.

How can we take care of our sexual organs?

Daily hygiene; not pocking inside them; being careful not to hit the organs; eating healthy, and exercising.

What can you do now that you know your body?

Take care of ourselves; understand it better; not letting other tells us false things about our body; love our body.

What risks might a women be in if she doesn't know and understand her body? 


\section{MENTOR STUDYING RESOURCE \\ Woman's Sexual Organs}

\section{External sexual organs}

Mount of Venus: The protruding area above the pelvic bone; after sexual development, that is covered with pubic hairs to protect the sexual organs.

Labia Majora: Two thick skin folds that protect the vaginal opening.

Labia Minora: Two thin and reddish skin folds that surround the vaginal opening. They have no hairs.

Clitoris: Small round sexual organ located in the anterior part of the labia minora. Its stimulation provides sexual pleasure.

Vaginal opening: An elongated opening where vaginal secretions, menstruation and babies come out. It leads into the internal organs of the reproductive system

\section{Internal sexual organs}

Uterus: A pear-shaped organ the size of a fist located in the pelvic region. Here is where the fetus develops during pregnancy

Cervix: Inferior part of the uterus and tubular in shape that connects the vagina to the uterus. Menstruation and sperms pass through here. During childbirth, it expands so the baby can go through.

Fallopian Tubes: Two long tubes on each side of the uterus. They connect the uterus to the ovaries. The endings near the ovaries are shaped like a flower. The egg travels through these tubes into the uterus.

Ovaries: Two oval shaped organs located at the end of the Fallopian tubes. They store the eggs as well as produce and secrete female hormones

Vagina: Channel that extends from the vulva to the uterus. It is a very elastic muscular organ that can stretch during sexual intercourse and child bearing.
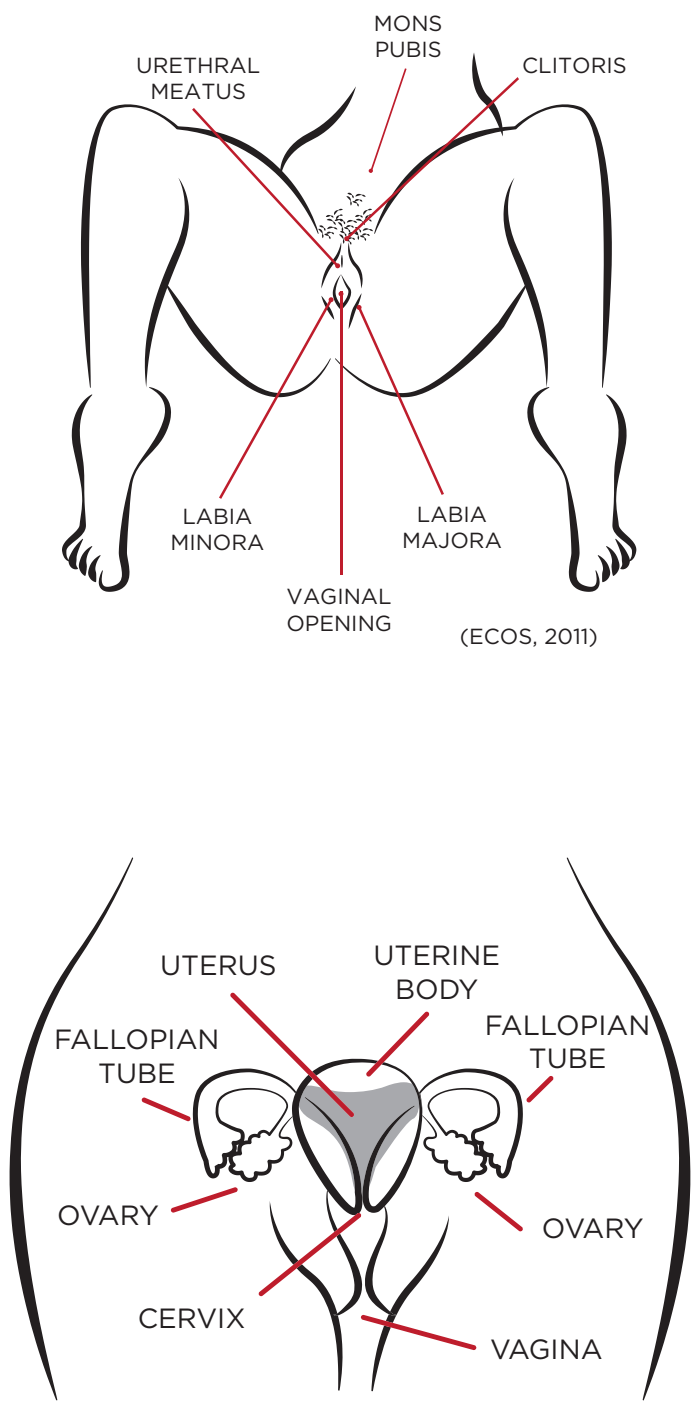

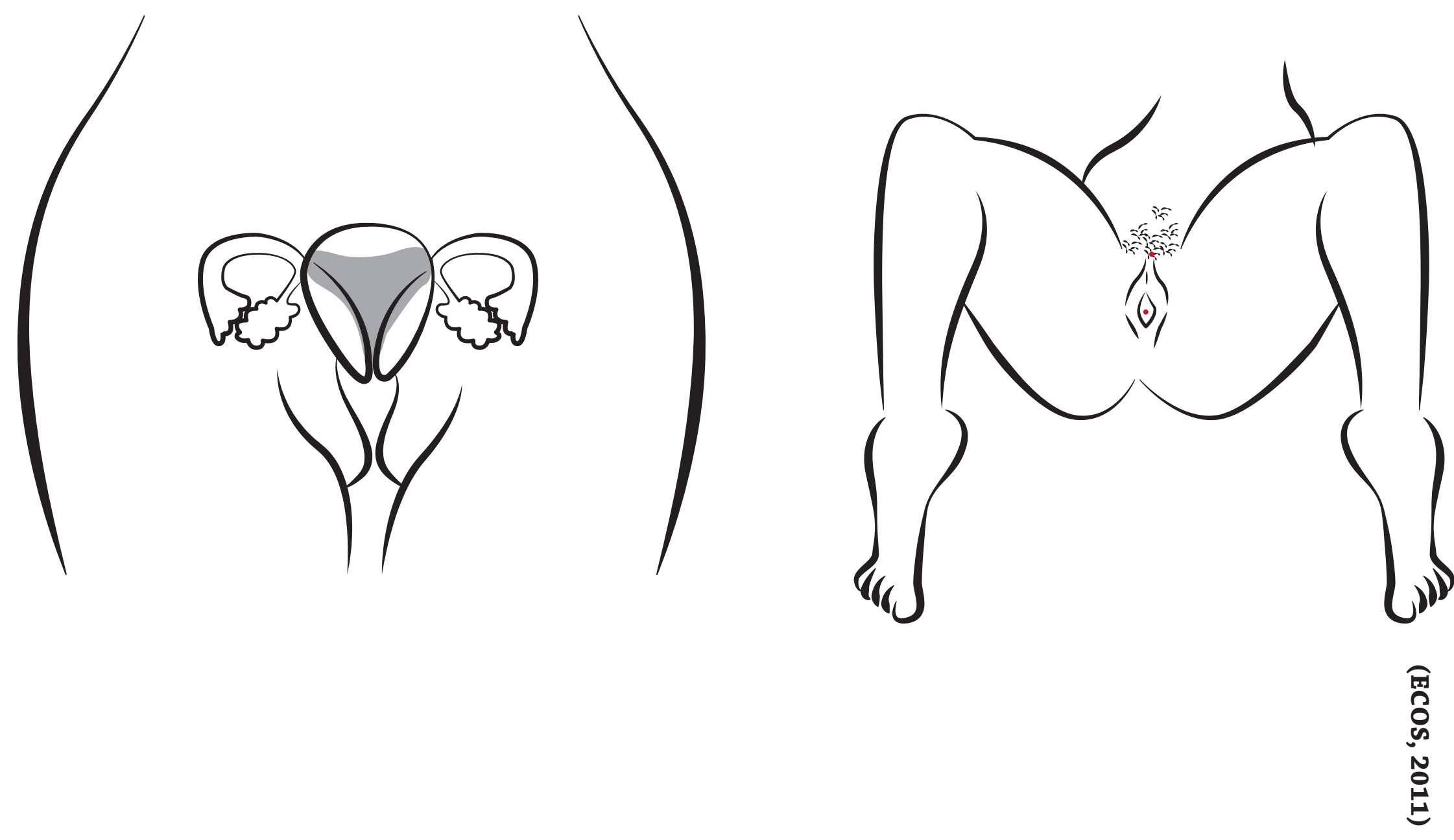


\section{menstrual cycle}

OBJECTIVES
By the end of this session, participants
will have:
- Learned the stages in a woman's
reproductive life.
- Identified the changes the body
undergoes during puberty.
- Learned the menstrual cycle and
differentiated facts from myths
concerning menstruation.

MATERIALS
- Flipcharts with the
silhouettes of the bodies
of a girl, an adolescent
girl, a mother and an
elder lady
- Crayons and markers
- Worksheet
- Poster with the internal
sexual organs, a drawing
of an egg, endometrial
blood, and drops of
blood
- Blank flipchart
- Labels with the internal
sexual organs

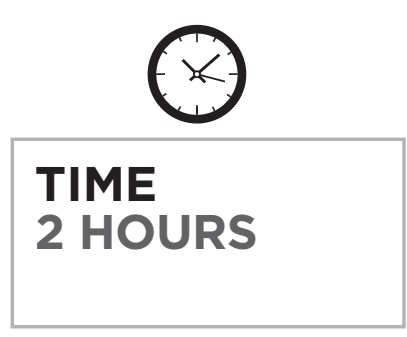

\section{KEY CONCEPTS}

Reproductive life stages: Puberty, reproduction and menopause.

Menarche: The first menstruation

Menstrual cycle: hormonal cycle that produces menstruation

Menopause: When a woman stops ovulating, and thus cannot become pregnant, and she experiences her last menstruation.

Childbearing age: Life period in which a woman can become pregnant, give birth and breastfeed.

Puberty: Life period in which an adolescent girl undergoes physical changes that lead to sexual maturity. 


\section{Welcame}

Welcome the participants and take attendance. Share with the participants that today they are going to learn about the changes their bodies undergo and will continue to have throughout their lives.

\section{Topic introduction}

Present the group with four flipcharts in front of the group: one with the silhouette of a girl, one with the silhouette of an adolescent girl, one with the silhouette of a pregnant woman and another with the silhouette of an old lady. Place them in random order. Tell them this is the silhouette of Juana throughout her life. Ask them to place the silhouettes in the correct order.

Ask the participants to form four groups. Give each group one of Juana's silhouettes and ask them to color it, draw a face, clothes, her hair and other things she would use according to her life stage and the estimation they do about Juana's age. They will also write what one day in the life of Juana is like at that stage. When they are done, ask them to come up front in order (girl, adolescent girl, mother, old lady) and share Juan's story. The rest must pay attention to Juana's life changes.

$\bigcirc$ At the end, ask:

What changes occur in each of Juana's life stages?

Write the answers on a flipchart

Some changes occur in Juana's body, in her behavior, the way she relates to others, and in her interests. Which changes happen to her body and which happen in her behavior?

On the flipchart, underline the body changes and circle the changes in behavior. What would you call each stage of change in Juana's life?

Write the correct names for each stage on the flipchart where it belongs:

\section{- First flipchart: Childhood}

- Second flipchart: Puberty

- Third flipchart: Reproductive age

- Fourth flipchart: Menopause

What process indicates the beginning and end of the Reproductive age?

The first menstruation (menarche), and the last menstruation (menopause). Write menarche on a flipchart and menopause on another.

\section{Theory and definition \\ $\bigcirc$ Tell the participants:}

In women's lives, as well as in men's lives, the body undergoes some changes, along with changes in behavior, responsibilities, and relationships with other people. The most evident changes in the body happen during puberty, and it is very important to learn them because they indicate the beginning of the reproductive phase. Which changes do you know the body undergoes during puberty?

\section{Write the changes on a flipchart for them to see.}

\section{Men}

- Shoulders become wider

- Hair growth in the underarms, legs, mustache, beard and pubic area around the penis.

- Development of sexual organs develop (the penis grows)

- Their voice changes

- Appearance of ejaculations

- Appearance of acne on the face and body.

\section{Women}

- Hair growth in the underarms legs, pubic area and external genital organs.

- Breast growth

- Hips widen

- Presence of menstruation

- Appearance of acne on face and body 
Tell the participants:

The period of changes during adolescence is called "puberty". These changes occur in the body, because the body is preparing itself for the reproductive phase. The menstrual cycle is the central part of this phase and every woman must know how the menstrual cycle works. We are going to learn how the menstrual cycle works which takes place in the woman's internal sexual organs.

Place a large poster of a woman's internal sexual organs in front of the group and review each organ's name together. Then, begin by explaining the menstrual cycle using the poster and the small drawings (egg and blood drops.)

\section{Say:}

a. When a woman has reached enough maturity for becoming pregnant, every month the brain sends a signal to the sexual organs to activate in case the woman wants to become pregnant. The first thing that happens is an egg matures inside the ovary (Place the drawing of a green egg inside the ovary to show it is matured).

b. Once the egg is mature, it enters the Fallopian tube and travels throughout the length of the Fallopian tube. (Move the egg throughout the length of the Fallopian tube).

c. While the egg is traveling, inside the uterus the endometrium thickens creating a thick layer of blood around the uterus. (Place a red stripe on the uterus wall, simulating the endometrium).

d. When the egg reaches the uterus and a sperm does not penetrate it, the layer of blood becomes detached from the uterus wall turning into the menstruation we see. To help the blood come out, the uterus contracts causing pain and menstrual cramps. (Remove the red stripes from the uterus wall and make as if they are coming out of the cervix and the vagina).

e. The bleeding lasts between 3 to 7 days. Every woman's body is different and therefore it is not possible to talk about an exact number of days between one menstruation and the next. However, there is a period of approximately 28 days between each menstruation. When a woman experiences her first menstruation, it means that she is ready to conceive a child every time she has sexual intercourse.
Ask a volunteer to come up front and explain the cycle using the drawings. While she is explaining, ask another volunteer to write down each phase on a flipchart. If necessary, repeat the process again so they understand it completely.

\section{Application in daily life}

Give the participants an opportunity to ask questions about the topic, in case it was not clear or they have any doubts. Tell the participants that when a girl has her period, she can still go out to play, walk to school, and do everything she normally does when she doesn't have her period.

Hand out the Menstrual Cycle calendar and tell them it's important to know our menstrual cycle. These sheets are for them to take track of their cycle on the calendar when it begins and when it ends and to do it for a few months to identify how many days their cycle is in order to prepare themselves to have the necessary items for their cycle (sanitary pads).

Ask the participants the following questions:

What is menstruation?

Why shouldn't we be embarrassed of menstruation?

What are three changes that occurred or will occur with you girls?

What characteristics does a man have when we think they are a good partner that loves us?

Hand the participants the worksheet "Is it true that...?". Ask the adolescent girls to work in pairs to identify whether what people say about the menstrual cycle is true or false. They can discuss the statements with their partners for more information and decide on their answer. If the statement written in the "Is it true that...?" column is a fact, they should check the space at the right where it says "Answer". If the statement is myth, they must write the correct version. Ask them to do this exercise with pencil, so after reviewing the answers they can correct anything by erasing it. Once the participants are done, ask what they wrote for each statement and guide them to the correct answer. 


\section{MENTOR STUDYING RESOURCE}

\begin{tabular}{|l|l|}
\hline Is it true that...? & Answer \\
\hline $\begin{array}{l}\text { During the menstruation days, it is not possible to have } \\
\text { sexual intercourse. }\end{array}$ & $\begin{array}{l}\text { False. If the woman and her partner agree, they can } \\
\text { have sexual intercourse during menstruation without } \\
\text { any problems. }\end{array}$ \\
\hline $\begin{array}{l}\text { An adolescent girl can become pregnant in the first genital } \\
\text { intercourse. }\end{array}$ & $\begin{array}{l}\text { True. In each genital intercourse there is a risk } \\
\text { (danger) of becoming pregnant. }\end{array}$ \\
\hline Menstruation is a disease. & $\begin{array}{l}\text { False. Menstruation is natural and it happens to every } \\
\text { woman. }\end{array}$ \\
\hline You should not go out during menstruation. & $\begin{array}{l}\text { False. During menstruation, there is really nothing a } \\
\text { woman cannot do. She can go out for walks, play, do } \\
\text { exercises, and eat anything. }\end{array}$ \\
\hline $\begin{array}{l}\text { During menstruation, you should not shower because it can } \\
\text { harm your vagina. }\end{array}$ & $\begin{array}{l}\text { False. The most important thing during menstruation } \\
\text { is to shower every day. }\end{array}$ \\
\hline pad must be changed at least three times a day. \\
\hline
\end{tabular}




\begin{tabular}{|l|l|}
\hline Is it true that...? & Answer \\
\hline $\begin{array}{l}\text { During the menstruation days, it is not possible to have } \\
\text { sexual intercourse. }\end{array}$ & \\
\hline $\begin{array}{l}\text { An adolescent girl can become pregnant in the first genital } \\
\text { intercourse. }\end{array}$ & \\
\hline Menstruation is a disease. & \\
\hline You should not go out during menstruation. & \\
\hline During menstruation, you should not shower because it can \\
harm your vagina.
\end{tabular}




\section{DAYS MENSTRUAL CYCLE}

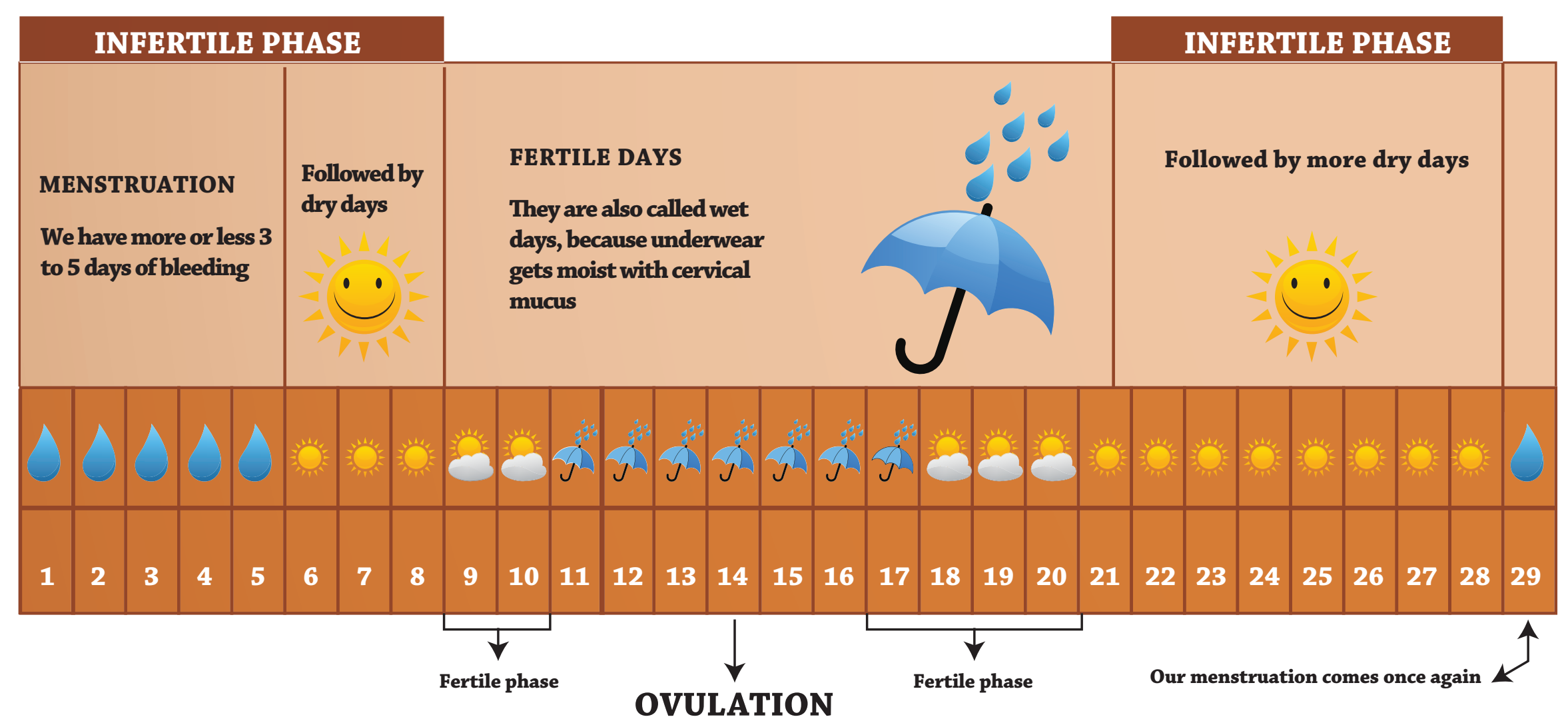




\section{IMPORTANT HYGIENE PRACTICES}

1. Use soap and water to wash the genital area every day.

2. Do not put anything inside the vagina.

3. Avoid getting hit in the genital area.

4. Do not let other people touch your body when you do not want them to.

5. Change underwear daily.

6. Exercise frequently.

7. When you have your menstruation, you have to change your sanitary pad at least three to four times a day, according to your need. 


\section{MENSTRUAL CYCLE}

\section{Month:}

\section{Sunday Monday Tuesday Wednesday Thursday Friday Saturday}

\begin{tabular}{|c|c|c|c|c|c|c|}
\hline Day: & Day: & Day: & Day: & Day: & Día: & Day: \\
\hline Cycle: & Cycle: & Cycle: & Cycle: & Cycle: & Cycle: & Cycle: \\
\hline Day: & Day: & Day: & Day: & Day: & Day: & Day: \\
\hline Cycle: & Cycle: & Cycle: & Cycle: & Cycle: & Cycle: & Cycle: \\
\hline Day: & Day: & Day: & Day: & Day: & Day: & Day: \\
\hline Cycle: & Cycle: & Cycle: & Cycle: & Cycle: & Cycle: & Cycle: \\
\hline Day: & Day: & Day: & Day: & Day: & Day: & Day: \\
\hline Cycle: & Cycle: & Cycle: & Cycle: & Cycle: & Cycle: & Cycle: \\
\hline
\end{tabular}




\section{MENSTRUAL CYCLE}

\section{Month:}

\section{Sunday Monday Tuesday Wednesday Thursday Friday Saturday}

\begin{tabular}{|c|c|c|c|c|c|c|}
\hline Day: & Day: & Day: & Day: & Day: & Día: & Day: \\
\hline Cycle: & Cycle: & Cycle: & Cycle: & Cycle: & Cycle: & Cycle: \\
\hline Day: & Day: & Day: & Day: & Day: & Day: & Day: \\
\hline Cycle: & Cycle: & Cycle: & Cycle: & Cycle: & Cycle: & Cycle: \\
\hline Day: & Day: & Day: & Day: & Day: & Day: & Day: \\
\hline Cycle: & Cycle: & Cycle: & Cycle: & Cycle: & Cycle: & Cycle: \\
\hline Day: & Day: & Day: & Day: & Day: & Day: & Day: \\
\hline Cycle: & Cycle: & Cycle: & Cycle: & Cycle: & Cycle: & Cycle: \\
\hline
\end{tabular}




\section{4) What is it like to be a woman? How were we taught to be women?}

OBJECTIVES
By the end of this session, participants
will have:
- Understood the difference between
sex and gender.
- Identified gender behaviors they
have learned.
- Understood that gender behavior is
learned at a very young age.
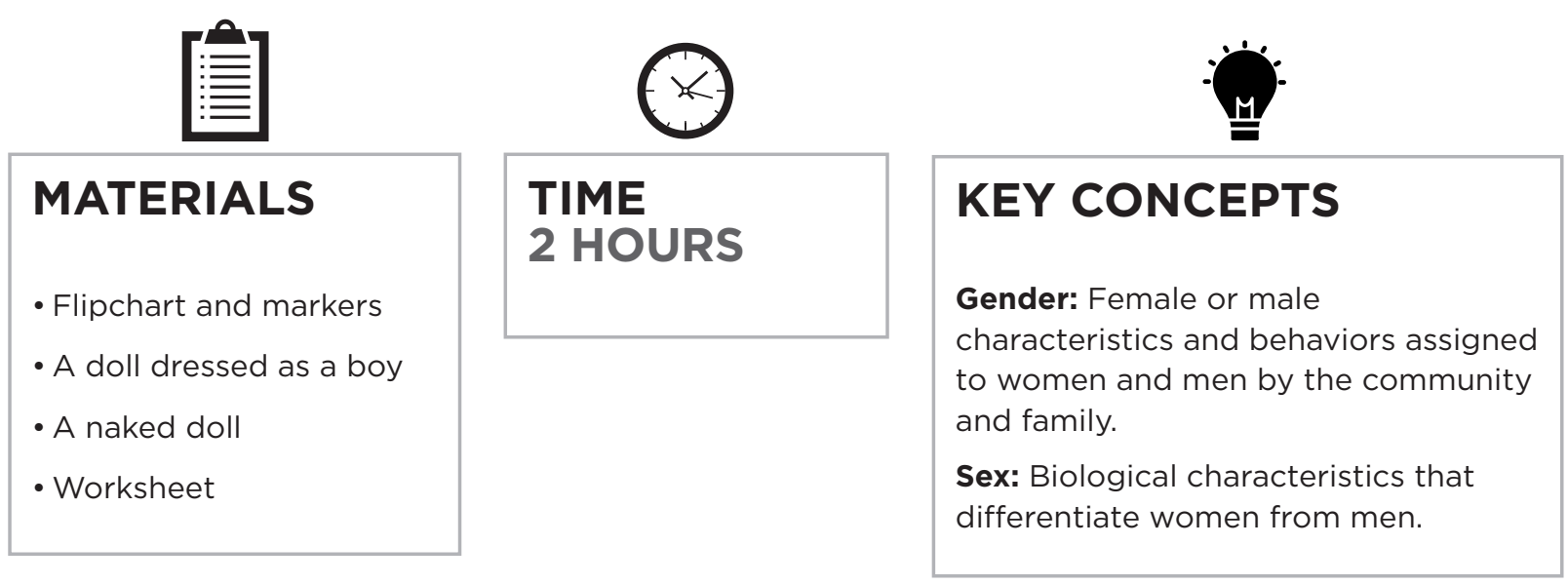


\section{Welcame}

Welcome the participants and take attendance. Share with the participants that today they are going to see the differences between women and men and try to understand where these differences come from.

\section{Topic introduction}

Show a doll dressed in boys' clothes. Say that this is the group's baby and that they have to take care of it. Ask them to name the baby and think of a job it would have when older. Then, ask them to come up to the flipchart and draw gifts they would give the baby for its first birthday.

While they are doing this, tell them it is time to change the baby's diaper, and ask one of the participants to come up front and change it. Once the baby is naked, ask the volunteer what external sexual organs she sees. Ask all the participants if the baby is a boy or a girl and why did they think it was a boy. Show a male doll without clothes or diaper and ask the group: What is the difference between girls and boys when they are this age?

\section{Ask:}

What sets the GIRLS apart from the BOYS when we are babies?

Write the answers on a flipchart: In one column write the answers for girls and on another the answers for boys. It may look something like this:

$\begin{array}{ll}\text { Girls: } & \text { Boys: } \\ & \\ \text { Vulva } & \text { Penis } \\ \text { Pink clothes } & \text { Blue clothes } \\ \text { Play with dolls } & \text { Play with cars } \\ \text { Help at home } & \text { Go to school and work the field } \\ \text { Long hair } & \text { Short hair }\end{array}$

\section{Theory and definition}

Of the differences they wrote, ask them to identify one by one if it is something we are born with or behavior that we've learned from the community. Mark with an $\mathrm{X}$ the things that come by birth and underline those that are learned or imposed by the community.
Ask:

Where do most of the differences between girls and boys originate?

From what it is learned and the community decides.

At what age does one learn to be a girl or a boy?

At birth; sometimes even before the child is born, the child is already determined by colors and girl-boy names.

\begin{tabular}{ll} 
Girls: & Boys: \\
Vulva & Penis \\
Pink clothes & Blue clothes \\
\hline Play with dolls & Play with cars \\
$\underline{\text { Help at home }}$ & $\underline{\text { Go to school and work the field }}$ \\
\hline
\end{tabular}

Explain to the participants the difference between sex and gender. Put in front of the group a flipchart that reads: The difference between sex and gender, followed by the table below. Explain each aspect and provide examples.

\begin{tabular}{|l|l|}
\hline \multicolumn{1}{|c|}{ Sex } & \multicolumn{1}{c|}{ Gender } \\
\hline Biological differences & $\begin{array}{l}\text { Social, behavioral and customs } \\
\text { differences }\end{array}$ \\
\hline Man and woman & Male and Female \\
\hline Defined by genes & $\begin{array}{l}\text { Learned since birth from the family, } \\
\text { school, church, community, media, } \\
\text { etc }\end{array}$ \\
\hline $\begin{array}{l}\text { Does not restrain men and women } \\
\text { from developing and being happy }\end{array}$ & $\begin{array}{l}\text { Established differences between } \\
\text { what's male and female, thus } \\
\text { restricting people's behavior and can } \\
\text { even lead to violence }\end{array}$ \\
\hline Cannot change & Can be transformed \\
\hline $\begin{array}{l}\text { Defines tasks during biological } \\
\text { reproduction }\end{array}$ & $\begin{array}{l}\text { Decides duties in life, the house, } \\
\text { society, etc. }\end{array}$ \\
\hline
\end{tabular}


If we go back to the differences between girls and boys, can you find anything that restricts girls from developing, being free, and happily thriving in life?

Yes, when a girl is not sent to school because she is going to get married, or when she is forced to get married, or when she is limited to house chores and children and cannot have a job and develop.

If gender characteristics are learned, can they be changed?

Can we also change those limitations for women?

Yes

Ask them to form pairs and give each pair the "Women and Men" worksheet. On the worksheet, they should write a "G" (Gender) if the characteristic is learned or write an "S" (Sex) if it is biological. Then they should write this how it affects men and women. At the end, check together the answers allowing one or two pairs to share their answers for each example.

\section{Application in daily life}

Participants are going to see how their gender has defined their identity. Give them "Thinking about my identity: more than gender roles" worksheet. 


\section{WORKSHEET: WOMEN AND MEN}

\begin{tabular}{|c|c|c|}
\hline & Gender / Sex & How it affects us? \\
\hline \multicolumn{3}{|l|}{ Women don't develop a career. } \\
\hline \multicolumn{3}{|l|}{ Women don't need to study. } \\
\hline \multicolumn{3}{|l|}{ Women become pregnant. } \\
\hline \multicolumn{3}{|l|}{ A good woman has many children. } \\
\hline \multicolumn{3}{|l|}{ Men get the family's inheritance. } \\
\hline \multicolumn{3}{|l|}{$\begin{array}{l}\text { A woman's mother-in-law is the one } \\
\text { who tells her what to do as well as } \\
\text { guide and control her. }\end{array}$} \\
\hline \multicolumn{3}{|l|}{$\begin{array}{l}\text { Women must marry young, be taken } \\
\text { care of by her husband and form a } \\
\text { family. }\end{array}$} \\
\hline $\begin{array}{l}\text { A woman is serious with men, doesn't } \\
\text { laugh with men, and doesn't joke with } \\
\text { men. }\end{array}$ & & \\
\hline
\end{tabular}




\section{Thinking About My Identity Beyond Gender Roles}

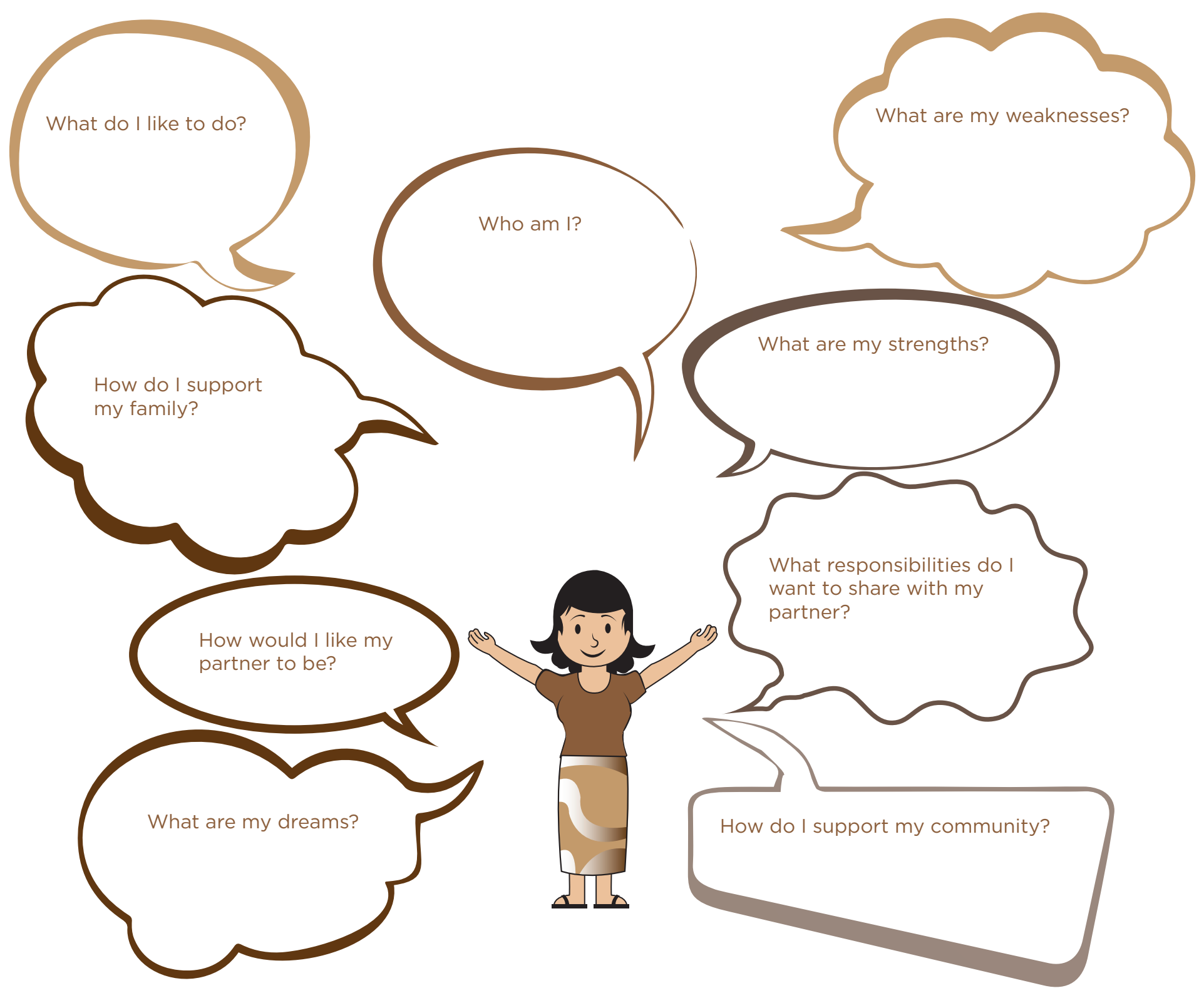




\section{5) Sisterhood: A new way for woman to relate to}

\begin{tabular}{|l|}
\hline OBJECTIVES \\
By the end of this session, participants \\
will have: \\
- Identified common problems that \\
women face in society. \\
- Learned what sisterhood is. \\
- Considered having another type of \\
relationship between women; one \\
where they can support, help and \\
advice one another, like sisterhood. \\
\hline
\end{tabular}

MATERIALS
- Worksheets
- Markers with the word
"Woman"
- Flipchart with the word
"women"
- Flipchart with the word
"sisterhood"
- Cases with blank spaces
for participants to
complete the story.

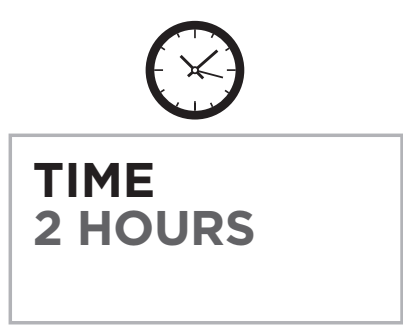

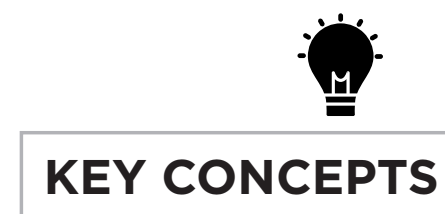

Sisterhood: type of relationship between women based on sisterhood. As women, we recognize that we share many problems that derived from the way the community thinks about our gender and impose us things that hinder our freedom and our rights to develop. Together we can improve the situation for all women, instead of competing with each other. 


\section{Welcame}

Welcome the participants and take attendance. Share with them that today they are going to talk about the way women are used to relating with one another.

\section{Topic introduction}

Form 5 groups and give each group a sheet of paper with one of the following incomplete cases. They must discuss the case, think about what happens in their community in similar situations, and complete the story by writing what the community does.

Case 1: A neighbor has just started to work in an office. She leaves her home dressed nice and looking pretty. The women neighbors watch her go out dressed like this, and among themselves they say...

Case 2: A student scores 100 points on the math test she studied very hard for. The teacher gives her a hug and congratulates her. Some of the girl classmates, who did not pass the test, look at her and say between them that ...

Case 3: A girl is on her way to school, but she is very exhausted from the house chores she has been doing since very early in the morning. She goes to buy atole, and she accidentally knocks over the pot full of atole. The vendor lady and the other girls buying atole saw her and said:

Case 4: An adolescent girl is walking down the street when a boy follows her trying to talk to her. She likes the boy and decides to stop and greet him. Her mother seeing her from afar thinks..

Once they are done writing the endings, have each group present the situation to the rest of the groups. After listening to all the cases, ask the participants:

What do the cases tell us about relationships between women? Where have we learned to act or behave like this towards other women?

How is each woman from the cases affected by the community's reaction towards her?

If women fight each other, who wins in violent situations? How can we support and help one another?

\section{Theory and definition \\ Tell the participants:}

Just like a person can beat or rape us, someone else can tell us hurtful things. Beatings and rape hurt our bodies, and listening to cruel words, can lower our self-esteem and make us feel so bad that we no longer wish to go forward in life or reach our goals and dreams. If we are always listening to these things, we start to believe them even though they are not true. For example, if a mother is always telling her daughter that she is dumb and worthless, the girl is going to think that she is dumb and worthless. But, we already know that each one of us is special and important.

Women have noticed that they had a lot of things in common, good things as well as very difficult problems in their lives. We can relate in

Teaching Tip

Acrostics are for strengthening a concept or description about something or someone. It gets people thinking about the meaning of the word they are turning into an acrostic and it also invites them to expand their vocabulary. For example an vocabulary. For example, an
acrostic for the word SUN:

Shiny

Universal

eNtity

a different way if we stop competing and criticizing one another and stop making each other feel bad. Women have similar challenges and problems and thus we could help and support one another. This way of relating is

SISTERHOOD. Instead of being divided and fighting against each other, we could form a big group of women where in the community, we can support one another. Whether we are victims of gossip or we are being told bad things, in these scenarios it is very important to believe in our worth and earn our respect.

Women and sisterhood acrostics. Paste a poster that reads "women" and another that reads "sisterhood". Invite the participants to do an acrostic together. With each letter of the word "women", they should write a problem or challenge shared by the women in their community. Brain storm with the participants about problems shared by women, asking:

\section{What problems do adolescents in this community share?}

After completing the acrostic of problems challenge the participants to make one with the word sisterhood, focusing on what kind of actions does sisterhood demand from us. Brainstorm with participants by asking:

How do women feel when they have to face problems alone? When women unite to solve problems, what could happen? 
When have you seen women supporting other women?

What actions can we do to become closer, support and help each other?

\section{Application in daily life \\ Ask the participants to go back to the same groups and write another} ending to each of their cases- an ending where women support each other. Then ask the groups to present their work.

Work on the worksheet "Less gossip, more friends" and "If someone tells me something that makes me feel bad". 


$$
5
$$


'GIRLS CREATING OPPORTUNITIES FOR A BRIGHTER TOMORROW' PROGRAM INTEGRATED CURRICULUM GUIDE

\section{Less Gossip, More Friends!}

What can I say or do if I hear rumors or gossips?
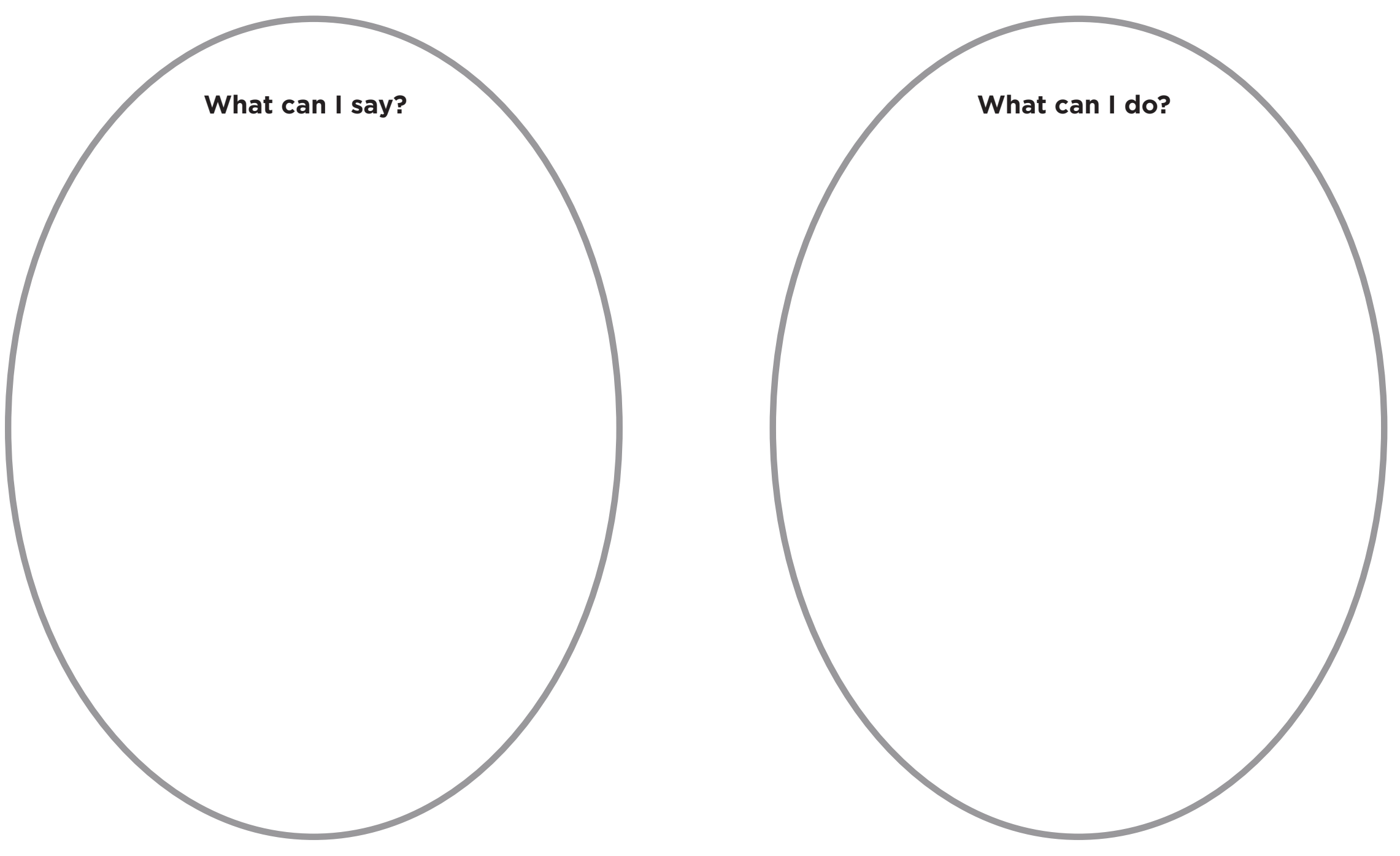


\section{6) I respect dignity when I communicate}

\begin{tabular}{|c|c|c|c|}
\hline $\begin{array}{l}\text { OBJECTIVES } \\
\text { By the end of this session, participants } \\
\text { will have: } \\
\text { - Learned to distinguish between } \\
\text { aggressive, assertive and passive } \\
\text { communication. } \\
\text { - Understood the reason why good } \\
\text { communication is an important way } \\
\text { to assert and respect one's dignity as } \\
\text { well as other people's dignity. } \\
\text { - Practiced strategies that improve } \\
\text { communication. }\end{array}$ & $\begin{array}{l}\text { MATERIALS } \\
\text { - Flipchart with the words: } \\
\text { Assertive, Passive, } \\
\text { Aggressive } \\
\text { - Drawing of a rooster, } \\
\text { rabbit and cat } \\
\text {-Worksheet } \\
\text { - Script cards for the fruit } \\
\text { activity }\end{array}$ & $\begin{array}{l}\text { TIME } \\
2 \text { HOURS }\end{array}$ & $\begin{array}{l}\text { KEY CONCEPTS } \\
\text { Communication: Transmission of } \\
\text { ideas and messages between two or } \\
\text { more persons by means of a common } \\
\text { language. } \\
\text { Assertiveness: Characteristic of } \\
\text { communicating in a firm and clear } \\
\text { manner. } \\
\text { Aggressiveness: Tendency to act or } \\
\text { respond violently. } \\
\text { Passiveness: Characteristic of } \\
\text { someone who allows others to do } \\
\text { anything and doesn't take the lead or } \\
\text { reacts responsibly. }\end{array}$ \\
\hline
\end{tabular}




\section{Welcame}

Welcome the participants and take attendance. Start the session by communicating with the participants without using words, by means of signs. Then explain that today's topic is about styles of communication.

\section{Topic introduction}

Play a game with the participants. Ask for three volunteers. These volunteers will guide the activity using different forms of communication when giving the instructions to the rest of the participants. Separate the three volunteers and instruct them that each one is going to ask her group mates to form $x$ number of groups by saying: "I want a basket with XX amount of fruits". Explain how each one will deliver her instructions.

The first volunteer will say it in a low tone of voice, looking at the floor and without ever raising her voice. Give her the following sentences on a card: "I bought three." "I wanted to by four, but there were only two, so I went to another vendor and asked for five."

The sencond volunteer should say it in a very clear, secure tone of voice looking at the other participants in the eye and saying exactly what she means to say, not a word less. She makes sure that the participants listen to her and un derstand. And if anyone has any questions, she repeats the amount. Give her a card with the following scirpt: "I went to the market and bought 6 fruits", "I went to the market and bought 8 fruits."

The third volunteer will say it in a very angry manner, yelling at them. She can talk very fast and if someone does not understand, she should angrily answer Give her a card with the following script: "Quickly! I want to by 2 fruits."

"Hurry up! I bought 9 fruits." "I said I only wanted to buy one fruit!" At the end of the game, ask:

How did you feel during the game?

When was it easier/harder to form the groups asked by the guides?

What is the difference between the way the guides spoke and asked for things?

When was it easier and when was it harder to follow the guides' instructions? Who made you feel safe and calm due to the way she gave the instructions?

\section{Theory and definition}

Show a drawing of a rooster, a rabbit and a cat. Ask the participants to give each volunteer the animal that bests represent the way she communicated. Read with the participants the key concepts and ask which of the three volunteers communicated in the passive form, which in the aggressive and which in the assertive. Then ask:

Which is the best way to communicate an idea, a message or a feeling? Which was the best attitude of the participants when listening to what the volunteers were asking?

What effect does the way we communicate have on our relationship with other people?

With communication style favor dignity and respect?

Hand out the "Saying what I want" worksheet and split participants in three groups. Assign one case to each group and have the girls work amongst on what would be a passive way to respond, what would be an aggressive way to respond, and what would be an assertive way to respond for that case. Have them share the solutions they have come up with when family, boys and other people are threatening their rights.

\section{Application in daily life}

Ask each participant to write on a piece of paper something she has always wanted to say to another person but did not have the courage or did not know how to say it. Show participants how to make paper airplanes and go out of the room, have them send off their message by flying their planes. Explain that they will couple. Each couple will share what they wrote down and think of the best and assertive way to say the message. They will practice it by play rolling. At the end, ask who would like to share the exercise with the rest of the group. 


\section{Saying What I Want}

Now girl, you are done with primary school. Soon you will be able to get together with the neighbor's son, go live with them and have children. Don't worry about continuing with your studies, you don't need it any more.

My love you are the most beautiful flower in the garden, when we get to be to be together you won't have to worry about anything, I will give you and our children anything you need. You won't have to work, study, or take care of anything. You are my princess, let's make love without any concerns, I will take care of you always.

If that happened to you it's because you looked for it. You should know that you have to obey without getting upset or doubting. Now you have to wipe off your tear, pull back your hair, you cover the bruises and get back there. At the very least you like these things to happen and that's why you keep asking for them. 


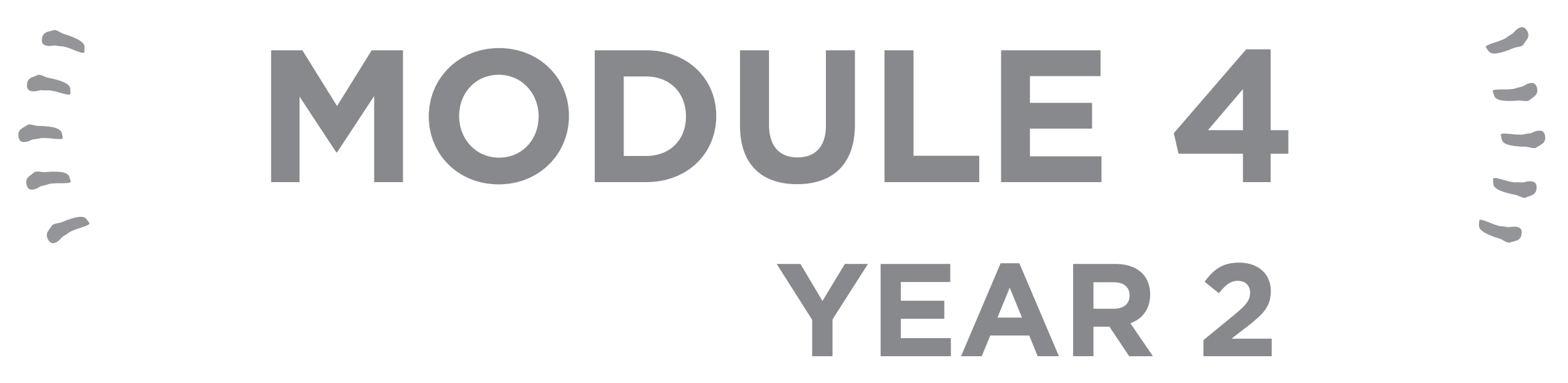




\section{MODULE 4}

\section{YEAR 2}

The second phase takes participants into exploring their potential as community leaders through community outreach. This module looks back at key topics such as safe spaces in their community inviting participants to think of strategies to change conditions that they have identified as limiting girls' and adolescent's development. It also provides the opportunity to enhance assets concerning sexual health and reproductive health.

\section{Group ages 8 to 12}

4.1 Girls Creating Opportunities for a Brighter Tomorrow: Which are the safe spaces in my community?

4.2 Health: Eating and Eating Nutritiously are not the same thing

4.3 Sexual and reproductive health: The menstrual cycle

4.4 Sexual and Reproductive Health: Pregnancy, decisions and family planning

4.5 Personal strengthening: I communicate assertively

\section{Group ages 13 to 17}

4.1 Girls Creating Opportunities for a Brighter Tomorrow: I build safe spaces in my community

4.2 Health: Nutrition

4.3 Sexual and Reproductive Health: Fertility, fertilization and pregnancy

4.4 Sexual and Reproductive Health: Sexual and reproductive rights

4.5 Gender: We are many diverse women working together 


\section{1) What are the safe spaces in my community?}

\begin{tabular}{|c|c|c|c|}
\hline $\begin{array}{l}\text { OBJECTIVES } \\
\text { By the end of this session, participants } \\
\text { will have: } \\
\text { - Identified which places can be safe } \\
\text { spaces for women in the community. } \\
\text { - Named people who they share safe } \\
\text { spaces with and know can be part of } \\
\text { their network of trust and support. } \\
\text { - Explained how gender affects girls' } \\
\text { safety and their access to different } \\
\text { places in the community. } \\
\text { - Designed a personal protection } \\
\text { strategy. }\end{array}$ & $\begin{array}{l}\text { MATERIALS } \\
\text { - Community maps } \\
\text { with strategic places } \\
\text { identified } \\
\text { - Markers } \\
\text { - Crayons } \\
\text { - Flip charts } \\
\text { - Worksheet }\end{array}$ & $\begin{array}{l}\text { TIME } \\
2 \text { HOURS }\end{array}$ & $\begin{array}{l}\text { KEY CONCEPTS } \\
\text { Citizen's safety: } \\
\text { Conditions that protect the wellbeing } \\
\text { of women and men of all ages in the } \\
\text { community. It recognizes and respects } \\
\text { Human Rights, as well as citizens' } \\
\text { participation. } \\
\text { Community network of trust: } \\
\text { The group of women, adolescents, } \\
\text { girls and other people in the } \\
\text { community we can ask for help and } \\
\text { we are sure they will protect us. } \\
\text { The community can work together } \\
\text { in converting more places in the } \\
\text { community to safe spaces for girls, } \\
\text { adolescents and women. } \\
\text { Protective measures: } \\
\text { Measures designed to keep people } \\
\text { safe from harm. }\end{array}$ \\
\hline
\end{tabular}




\section{Welcame}

Welcome the participants and take attendance. Show them how happy you are to see them again and to continue working through the Girls Creating Opportunities for a Brighter Tomorrow sessions. Some of the most interesting topics and fun activities are coming up this year. Share with the girls that today we will be talking about their community and how they

feel in it now that they have been part of the network of friends in the safe space for one year

Teaching Tip
Bring a flipchart with faces
that show different emo-
tions a girl might feel. Like:
happy, excited, entertained,
interested, loved...

Ask them to present themselves again but this time they will mention how belonging to the $\mathrm{AO}$ community of trust makes them feel. Motivate them to recognize many feelings beyond "good" and "happy".

\section{Topic introduction}

Put a giant flip chart on the floor together with markers and crayons. Invite participants to draw the Girls Creating Opportunities for a Brighter Tomorrow safe space. Remind them that a safe space is more than walls, windows and floors; insist they include who meets at the safe space, what happens in it, how they feel when there, relationships in the safe space etc. When finished, hang the flipchart up on the wall so everyone can see it and make a list of the characteristics of the safe space. Write down the characteristics on a flip chart and emphasize the ones that have to do with the way they treat and help each other in the space.

\section{Theory and definition}

They will work in groups to identify safe and unsafe spaces for boys and girls in the community. Explain that they are going to create the "girl map". Hand out an empty flipchart to each group and ask them to draw a map of their community including as many places as they can. Make sure every groups map is as complete as possible. Once their maps are drawn, ask them to identify places in the community that are safe spaces for them and in which they feel the most secure and comfortable. Each of these spaces shall be marked with a happy face.

Guide the group discussion, marking down the main ideas about safe spaces for women on the board.

\section{Ask them}

Which spaces are safe for girls?

What activities do girls and women do in those places?

\section{Domestic activities, studying and playing}

Which places are not safe for girls?

How does danger in these places limit girls' development?

\section{It is difficult to do things outside of the home} because of the risks there are in those places.

What places do we need to be made safe for us, in order to be active citizens, community leaders and lead full productive lives?

\section{Meeting spaces, market, municipal building, transportation}

\section{Say to the participants:}

There are the places that you would like to be safe for girls. A space is safe according to its location and the materials it's made with, but also because of the way we feel, learn, and are treated in them. Some safe spaces can be safe for periods of time and during other times become unsafe; it all depends on who is there, what's going on and what intentions people have. Let's brainstorm to name as many people as we can that can and will be willing to help us turn more places into safe spaces for girls.

Write all their suggestions on a flipchart and invite them to also mention how each person can help and how to assertively ask her/him for help.

\section{Application in daily life}

Hand each participant a "Safe Spaces" worksheet. Tell the participants that they should think about where they spend most time during the day. They will write them down and then rate the level of safety for each place. They will mark one star for the places that are not safe, two stars for those that are sometimes safe and sometimes unsafe and three stars for spaces that are always safe.

For every place they can write what they can do with to make it safe and who they can work with. To finish, open up the opportunity for participants to voluntarily share their answers with the group. 


\section{Safe Spaces}

Write the places where I spend most time and rate their level of safety (1star-unsafe, 2-sometimes safe, 3-always safe).
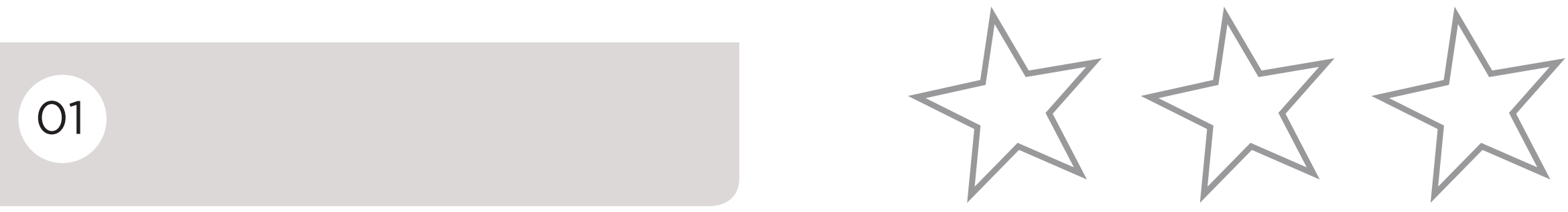

\section{2}
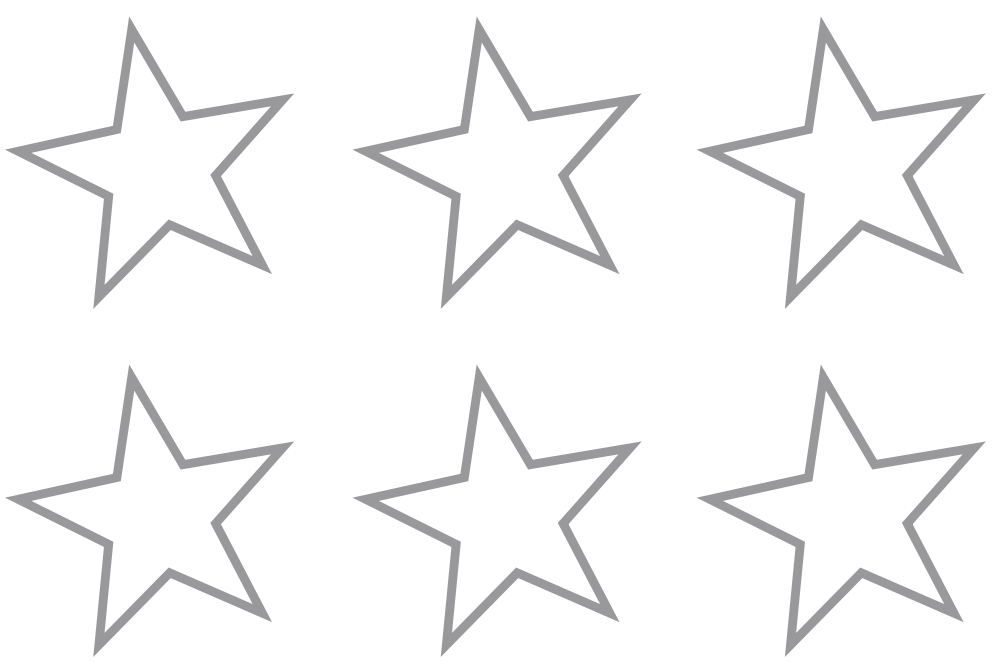

What can I do to make them safer for me and other girls in the community? Who can help? 


\section{2) Eating and Eating Nutritiously are not the same thing}
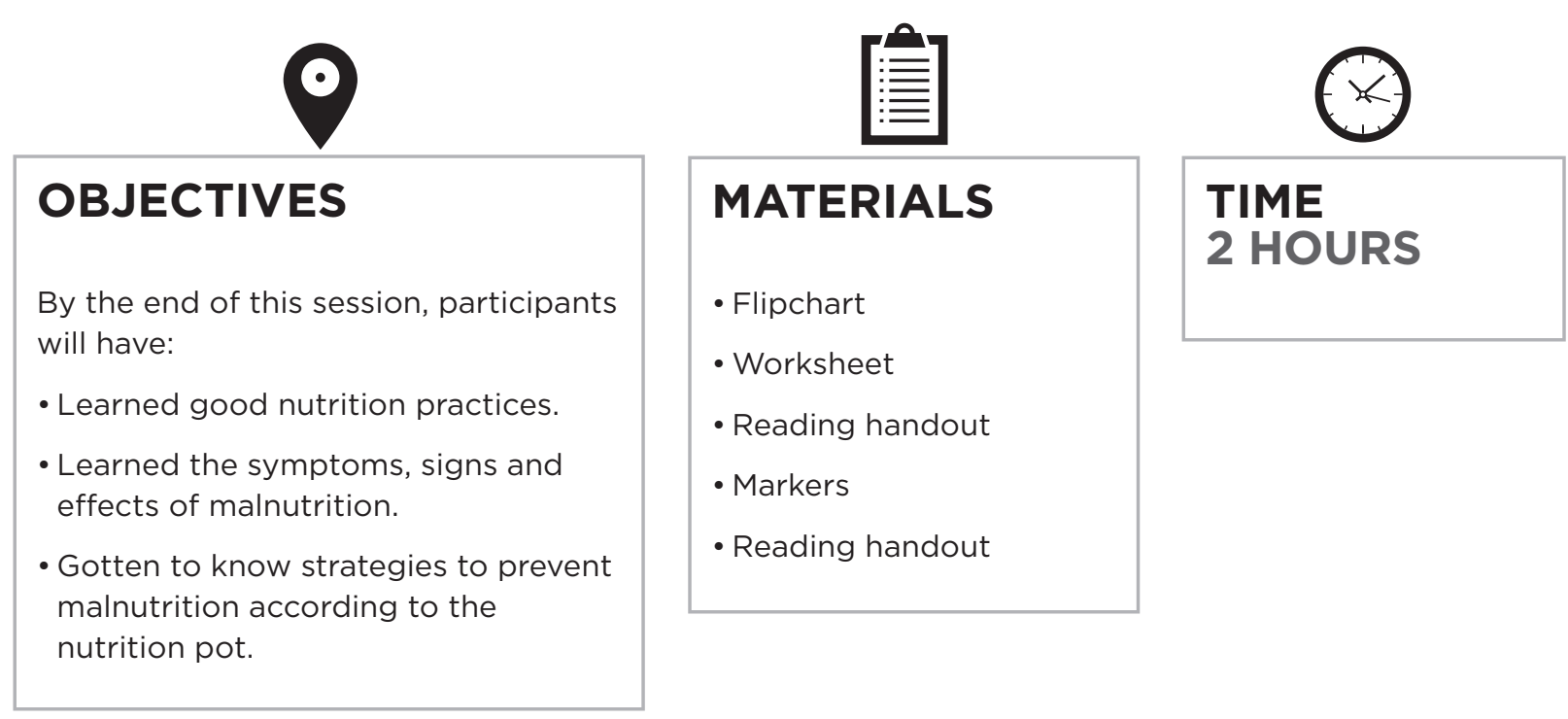

KEY CONCEPTS
Nutritious foods: Those that provide
an important amount of vitamins,
minerals and proteins, while also
satisfying our hunger and making our
bodies healthy.
Nutrition Pot for Belize: A context
specific scheme of recommended
foods and possible alternatives in
Belize.




\section{Welcame}

Welcome the participants and take attendance. Remind them it is important to keep coming to continue learning the topics.

\section{Topic introduction}

Play "Simona Eats" with the girls. Explain that you will say the name of foods that Simona has eaten today and if it is a food that makes you strong they will jump. If it is a food that makes you weak they will throw themselves on the floor like they have fainted. After playing three rounds, ask for a volunteer to lead the following rounds.

Write the foods they mention on a flipchart. Take a moment with participants to mark what foods, from the flipchart, are nutritious and which are not. Go through each food, making a check if it is nutritious and an $\mathrm{X}$ if it is not.

\section{Theory and definition}

Place a poster with the nutritional pot for Belize and say to the group:

Our health and energy depend on what we eat and how we eat it. Eating is not the same as eating nutritiously. Everybody needs certain types of nutrients to be in good condition and we nourish ourselves with different foods to take advantage of the richness of the land.

Give participants the reading handout "Nutritious Food of Belize" and read all of the information that it contains. Motivate them to make questions and comments as you go along. After reading have participants mark the foods that they have had in the last week. If they are not on the poster they can draw them in the part of the pot that corresponds to that type of food. Then dialogue about their nutritional habits with following questions:

\section{How close are we to following the advice provided?}

$$
\text { Is it easy to follow this nutrional model? Why? }
$$

Can we share this information at our homes with people that are in charge of providing and preparing our foods?

\section{Application in daily life \\ Ask the participants:}

Why is it important for women to know what different foods do for us? Why is it important for women to combine many different nutrients in their diet?

What do instant soups, Tortix and sodas provide to the nutritional pot?

What cheap items could we substitute for these foods?

Handout the "Nutrition Garden" worksheet and have them draw which plants and animals they would have in their garden to have access to healthy and nutritious food. 


\section{Nutritious Foods of Belize}

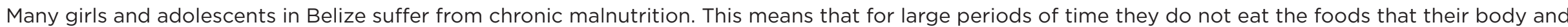

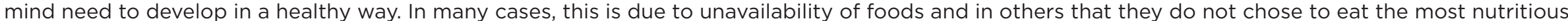

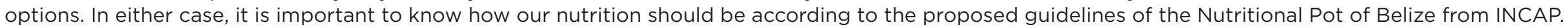

\section{Six Basic Food Groups and Frequency of Consumption}

Meat: at the least once a week

Greens and vegetables: every day

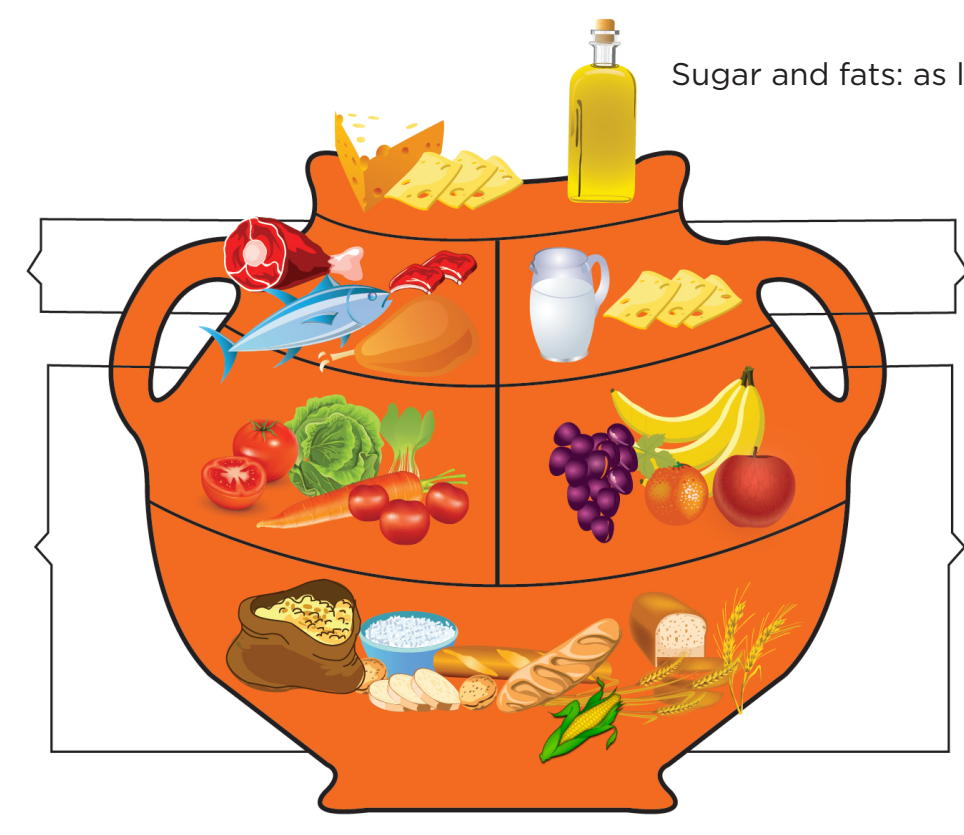

Milk and derivatives: at least twice a week

Fruits: every day

Grains, corn and

potatoes or casava:

every day

\section{Recommendations:}

1. Combine grains, cereals and potatoes in every meal.

2. Always eat greens and vegetables to strengthen your body.

3. Eat fruit everyday - whichever one it might bebecause they are healthy, good for digestion and nutritious.

4. Combine every tortilla that you eat with a spoon of beans. This is almost the same as eating a piece of meat.

5. Complete your diet by including an egg, a piece of cheese or glass of milk a few times a week.

To stay healthy always wash your hands and cover your food and water. 
'GIRLS CREATING OPPORTUNITIES FOR A BRIGHTER TOMORROW' PROGRAM

INTEGRATED CURRICULUM GUIDE

\section{Nutritious Garden}

Draw what a nutritious garden would look like according to the Nutritional Pot recommendations.

What plants from your community will you could include? What animals could you have as well? 


\section{3) I can protect my body}

OBJECTIVES
By the end of this session, participants
will have:
- Recognized that protecting and
taking care of their body is their right
and responsibility.
- Identified actions that put the
wellbeing of their body and dignity
at risk.
- Named people that can help them
protect themselves.

\begin{tabular}{|l|}
\hline MATERIALS \\
- Flipchart \\
- Markers \\
- Poster with sexual and \\
reproductive rights \\
- Paper arrows \\
\hline
\end{tabular}

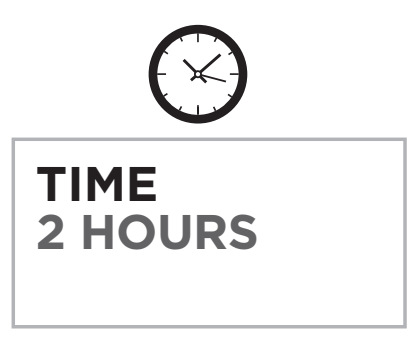

A group of rights that protect the sexual and reproductive health of men and women of all ages. Every person

in the world, of all ages and both sexes is entitled to these rights. 


\section{Welcame}

Welcome the participants and take attendance. Ask how they have tried to eat more nutritiously and what has been their experience. Brainstorm a list of strategies they can protect their body.

\section{Topic introduction}

Form groups of three and hand each group a flipchart that says "My body is in danger when..." and give them time to make a drawing of the times they have felt that their body was in danger. Allow each group to present their work to everyone.

\section{Theory and definition}

Share with the group that just like there are rights to protect nutrition, education and recreation, there are specific rights to protect their general health as well as their sexual and reproductive health.

Present the following poster and read the contents with participants.

\section{My Rights}

The right to know my body, the body of men and learn about sexual and reproductive health.

The right to decide when and who I will allow to touch my body.

The right to be respected in my sexual practices.

The right to the best medical treatment to take care of my sexual organs throughout my entire life, especially during pregnancy.

The right to decide if I want to have children or not, when, how many and with whom I want to have them.

The right to be protected from forceful sexual intercourse.

The right to legal assistance in the case of sexual abuse, rape or sexual assault.

\section{Application in daily life}

Ask participants to group up with their friends to read Lupita's story and answer the questions on a flip chart.

"Lupita was born into a family with six children, she was the youngest of four brothers and two sisters. Even though her family works the land as farmers, sometimes they do not have enough food for everyone, especially for Lupita who is a small girl.

When she was six years old, Lupita began going to school. But after two years she had to stop attending because there was not enough money to send all of the children. She stayed at home to help her mother care for her younger brothers, do household chores and cultivate corn. She no longer learned about her body or her rights.

One day Lupita stayed home alone because her family went to the fields and she didn't feel well. A man came to the door; Lupita thought he was one of her relatives, but he didn't feel like a relative and she didn't trust him. When he saw that Lupita was at home alone on the bed, he came up to her and started to touch her in a way that she didn't like at all. After that, every time she saw him she felt uncomfortable and wanted to cry.

Which of Lupita's rights were not respected in the story?

What actions in the story were wrong?

Which people are responsible for taking care of Lupita?

What can Lupita do about the situation she is in?

Who can Lupita ask for help?

How can the Girls Creating Opportunities for a Brighter Tomorrow mentor help Lupita?

After a bit of time, ask them all to share their answers with the group. At the end, write this title on a flipchart:

Who can we ask for help to protect our body when we feel like it's in danger?

Write the list made by the participants of the people, places and institutions in the community that they can ask for help. Write as much detail as possible, using names of people or how to get to the places. Demonstrate to the group that you are also one of the people they can come to for help. 


\section{Lupita's Story}

"Lupita was born into a family with six children, she was the youngest of four brothers and two sisters. Even though her family works the land as farmers, sometimes they do not have enough food for everyone, especially for Lupita who is a small girl.

When she was six years old, Lupita began going to school. But after two years she had to stop attending because there was not enough money to send all of the children. She stayed at home to help her mother care for her younger brothers, do household chores and cultivate corn. She no longer learned about her body or her rights.

One day Lupita stayed home alone because her family went to the fields and she didn't feel well. A man came to the door; Lupita thought he was one of her relatives, but he didn't feel like a relative and she didn't trust him. When he saw that Lupita was at home alone on the bed, he came up to her and started to touch her in a way that she didn't like at all. After that, every time she saw him she felt uncomfortable and wanted to cry.

Which of Lupita's rights were not respected in the story?

What actions in the story were wrong?

Which people are responsible for taking care of Lupita?

What can Lupita do about the situation she is in?

Who can Lupita ask for help?

How can the Girls Creating Opportunities for a Brighter Tomorrow mentor

help Lupita? 


\section{4) Health: Pregnancy, decisions and family planning}

\begin{tabular}{|l|}
\hline OBJECTIVES \\
By the end of this session, participants \\
will have: \\
- Learned that an adolescent can \\
get pregnant once she begins \\
menstruating. \\
- Listened to the risk of maternal \\
death and danger symptoms. \\
- Explained why as women we have \\
the right to decide when, how many \\
and with who we want to have \\
children. \\
- Learned that there are strategies to \\
plan on the kind of family we want to \\
have.
\end{tabular}
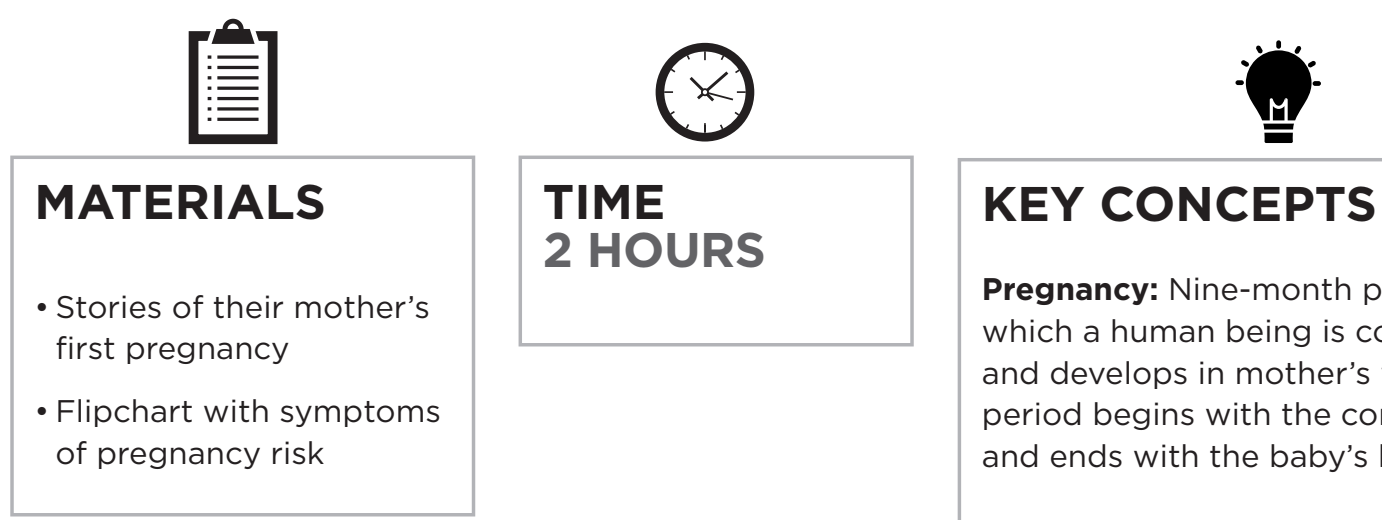

Pregnancy: Nine-month period during which a human being is conceived and develops in mother's womb. This period begins with the conception and ends with the baby's birth.

Maternal Death: is the death of a woman while pregnant or within 42 days of termination of pregnancy, causes related to or aggravated by the pregnancy or its management but not from accidental or incidental causes. 


\section{Welcame}

Welcome the participants and take attendance. Ask if one of the girls' mother is pregnant at that moment and let her share about the experience. Thank her for sharing this intimate family information with the group. Ask them to guess what today's lesson is about.

\section{Topic introduction}

Invite participants to share the stories that their mothers shared with them While they are doing that, write the conditions under which the mothers gave birth on a flipchart.

Ask the participants:

What similarities do you see between the stories?

What differences?

What age were the mothers when they had their first pregnancy?

What changed in their lives after their first pregnancy?

How does a women become pregnant?

What do men have to do with women getting pregnant?

\section{Theory and definition}

Say to the participants:

Girls' mature and start to menstruate, this is a signal that her body is preparing itself for reproduction. A baby is created when a woman and a man have sexual intercourse and fertilization occurs thanks to both of them. A girl can become pregnant from her first menstrual cycle.

Pregnancy lasts nine months so that the baby has enough time to form, grow and get strong before being born. When a woman is pregnant or after giving birth her body is dedicated to supporting this new life as well as taking care of herself. Mothers deserve special care, and should wait at least two years for her body to recuperate before she becomes pregnant again. When a woman is pregnant she also needs to be aware of changes in her body and symptoms of illness.

\section{Ask participants:}

Why is it important to have time between one baby and another? Who is the principal person affected by pregnancy and birth?

Who should be the main person to decide when and how many babies to have?

Hang a flip chart in the front of the room with the signs of danger during pregnancy and after birth. Read with participants and discuss how

these are related to pregnancy or birth.

Remember any story that included these symptoms and what mothers did.

\section{Ask the girls:}

What should a woman do if she finds herself with these symptoms?

Do you know that men and women can plan when to have children?

What have you heard about family planning and how to avoid pregnancy?

\section{Application in daily life \\ Myth or Fact}

Read the following statements and ask participants to jump to the right if they thing that what you say is a myth and jump to the left if it is a true fact. After each phrase share with them the correct answer. Allow time for them to ask questions and resolve any doubts.

When a girl has her first period or menstruation, she can get pregnant if she has sexual intercourse with a man.

\section{TRUE}

It is not healthy for a girl to bathe or swim while she is menstruating.

\section{FALSE}

A girl cannot get pregnant if she has only had sexual intercourse a few times. FALSE 
A woman can avoid getting pregnant if she knows how and uses effective strategies for avoiding pregnancy.

$$
\text { TRUE }
$$

The man should tell the woman how many babies she will have and decide when to have them. The woman should just accept this and follow his orders.

$$
\text { FALSE }
$$

There are ways that exist to avoid having babies and as women we have the right to know them, demand them and use them.

$$
\text { TRUE }
$$




\section{5) I communicate assertively}

\begin{tabular}{|c|c|c|c|}
\hline $\begin{array}{l}\text { OBJECTIVES } \\
\text { By the end of this session, participants } \\
\text { will have: } \\
\text { - Experimented with aggressive, } \\
\text { passive and assertive } \\
\text { communication. } \\
\text { - Understood why good } \\
\text { communication is important to value } \\
\text { and respect their dignity and the } \\
\text { dignity of others. } \\
\text { - Practiced techniques that improve } \\
\text { communication. }\end{array}$ & $\begin{array}{l}\text { MATERIALS } \\
\text { - Flip chart } \\
\text { - Markers } \\
\text { - Drawings of a rooster } \\
\text { - Rabbit and cat Flip chart } \\
\text { with the words Assertive, } \\
\text { Passive, and Aggressive } \\
\text { written on it }\end{array}$ & $\begin{array}{l}\text { TIME } \\
2 \text { HOURS }\end{array}$ & $\begin{array}{l}\text { KEY CONCEPTS } \\
\text { Communication: Transmission of ideas } \\
\text { and messages between two or more } \\
\text { people through a common language. } \\
\text { Assertive communication: } \\
\text { Characterized by communication that } \\
\text { is affirmative and clear. } \\
\text { Aggressive communication: } \\
\text { Presented in a violent manner without, } \\
\text { uses accusations and doesn't allow } \\
\text { dialogue. } \\
\text { Passive communication: } \\
\text { Characterized by being timid, not } \\
\text { communicating clearly and difficulty } \\
\text { transmitting the main idea. }\end{array}$ \\
\hline
\end{tabular}




\section{Welcame}

Welcome the participants and take attendance. Begin the session by trying to communicate with the girls without talking by using signs. Allow the girls to follow your lead and have some of the girls play with the group along with you.

\section{Topic introduction}

Invite participants to share the stories that their mothers shared with them. While they are doing that, write the conditions under which the mothers gave birth on a flipchart.

Play with participants to form boats with passengers.

\section{Say to them:}

We are going to play, I am going to say "Form boats with a certain number of passengers and you all have to come together in groups with that number of people." Those that are left without a group have to be the first to be taken into account for the next round of forming groups.

Call it the first time very quietly while looking down at the floor without seeing the girls and making the story longer.

Form boats of various passengers, but I don't know how many, maybe of one but no two, or maybe three or maybe two or more but it can't be more than four passengers, the same as one plus two is three.

See how they are confused because the communication was not clear and direct. Now to give the next instruction be clear and speak in a strong voice looking at them in the eyes and saying exactly what you want to say, no more and no less:

Form boats of five passengers.

For the third set of instructions, do it angrily, yelling at them and with more attitude. You can say it fast and if someone does not understand answer them negatively. You can say:

Quick I want boats of two people hurry up. I said two not nine! What is going on with this group???
To finish the game ask the group:

How did you feel during the game?

What moments were the most difficult/easy to form the groups that I asked?

What was the difference in the way l asked you to form the groups?

The first time was not clear and couldn't be understood. The second was

very clear and direct and there was no confusion. The third time was

annoyed and bossy and it couldn't be understood clearly what you wanted or why you were angry.

When did you feel the safest and calm about my way of giving instructions?

\section{Theory and definition}

Write down what they said on a flipchart, noting the three forms of communication:

\section{-Confused, indirect, not very clear}

\section{-Very clear, brief and direct}

\section{-Angry, bossy and yelling}

Present drawings of a rooster, rabbit and cat. Read the key concepts with them and ask them to mention which of the three forms of communication you used when giving instructions. Hang the drawings in the order that corresponds with where the three forms of communication are written. Ask them:

Which is the best way to communicate an idea, message or feeling?

\section{Share the following story with the participants:}

Josselyn is in the fourth grade and is a very good student. She is such a good student that she always gets the highest grade in the class on her work. Her classmates, especially the boys, like to bother her to make her feel bad for her grades and to make themselves feel better because they can't pass a single exam. This morning the teacher returned homework and once again congratulated Josselyn for her excellent work, but she didn't like it because she knew they were going to tease her. During recess she hadn't even gotten to the door when the boys were already together to bother her. Josselyn felt something deep in her stomach that she wanted to say and...

Ask the participants to form three groups have them prepare a skit of what Josselyn should say to them in an assertive manner. Let each group present their proposal. 


\section{Application in daily life}

After hand a piece of paper to each girl and ask them to write something they have really wanted to say to someone else but have not tried to or does not know how to. Once everyone has written their phrase, ask them to get together in pairs with someone they trust and share with them what they wanted to say but do not know how. Together they should decide what the best way to say it is and practice with each other. To finish up those that want to share with the rest of the group can do so. 


\section{1) I build safe spaces in my community}

\begin{tabular}{|c|c|c|c|}
\hline $\begin{array}{l}\text { OBJECTIVES } \\
\text { By the end of this session, participants } \\
\text { will have: } \\
\text { - Identified places that are safe spaces } \\
\text { for girls, adolescents and women in } \\
\text { the community. } \\
\text { - Named people who they share safe } \\
\text { spaces with and know can be part of } \\
\text { their network of trust and support. } \\
\text { - Explained how to be safe and access } \\
\text { to spaces in the community. } \\
\text { - Learned protective measures for } \\
\text { citizen's safety, specifically for } \\
\text { women, and adapt them to their } \\
\text { community. }\end{array}$ & $\begin{array}{l}\text { MATERIALS } \\
\text { - Community maps } \\
\text { - Markers: red, yellow, } \\
\text { green } \\
\text { - Flipchart } \\
\text { - Worksheet } \\
\text { - Labels with sentences to } \\
\text { complete }\end{array}$ & $\begin{array}{l}\text { TIME } \\
2 \text { HOURS }\end{array}$ & $\begin{array}{l}\text { KEY CONCEPTS } \\
\text { Citizen's safety: Conditions that } \\
\text { protect the wellbeing of women and } \\
\text { men of all ages in the community. } \\
\text { It recognizes and respects } \\
\text { Human Rights, as well as citizens' } \\
\text { participation. } \\
\text { Community network of trust: The } \\
\text { group of women, adolescents, girls } \\
\text { and other people in the community } \\
\text { we can ask for help and we are sure } \\
\text { they will protect us. The community } \\
\text { can work together in converting } \\
\text { more places in the community to } \\
\text { safe spaces for girls, adolescents and } \\
\text { women. } \\
\text { Protective measures: measures } \\
\text { designed to keep people safe from } \\
\text { harm. }\end{array}$ \\
\hline
\end{tabular}




\section{Welcame}

Welcome the participants and take attendance. Show them how happy you are to see them again and to continue working through the Girls Creating Opportunities for a Brighter Tomorrow sessions. Some of the most interesting topics and fun activities are coming up this year. Share with the girls that today we will be talking about their community and how they feel in it now that they have been part of the network of friends in the safe space for a year.

\section{Topic introduction}

Put a giant empty flip chart on the floor, invite participants to sit around it and put down lots of markers and crayons.

$\int$ Say to the group:

We are going to build the image of a safe space together. One of you is going to start the list by saying your name and drawing one element of safe space in the chart. That person will hand the marker over to anyone she wants and bring her to the center in the circle for her to present herself and add a new element to the image we are building together. We will continue until we reach the last person. There one special condition- nobody can repeat an element a said previously.

\section{Theory and definition}

They will work in groups to identify safe and unsafe spaces for girls, adolescents and women in the community. Explain that they are going to make a gender map which is a map that identifies places outside of the home that are safe spaces for boys, girls and both. Divide them into groups of three and hand out a map of the community to each group (as a base you can use the map they made at the beginning of their paths) and three colored markers.

Say to the participants:

I am handing you a map of the community and three colored markers. You should discuss about places in the community were girls, adolescents and women. Think about safety in each place; if it is a safe one for girls, adolescents and women who go there circle it with the green marker, if it is sometimes safe and others unsafe mark it color yellow. And if it's never safe for girls' adolescents and women mark it green. Remember what a safe space is according to what you all said during the game at the beginning of the session.

Allow them to work in their groups for 20 minutes. Later ask them to hang up their flip charts in the front so the entire group can see them. Invite participants to look at each other's posters. Guide the group discussion, marking down the main ideas about safe spaces for women on the board.

\section{Ask them:}

What spaces are safe for women?

House, school, Girls Creating Opportunities for a Brighter Tomorrow

What activities are done for women on the safe spaces for them?

Domestic activities, studying and playing

What places are not safe for women?

Streets, market, municipal building

How do the spaces that are not safe make it difficult for women to participate be leaders, study and work outside of their homes?

\section{It is difficult to do things outside of the home because of the risks there are} in those places.

What places do women need to be able to go in order to be active participants, leaders, develop, etc.?

\section{Meeting spaces, market, municipal building, transportation}

Do boys and men have access to similar safe spaces in the community?

Are there spaces that are unsafe for women but safe for men?

How does this affect participation in the community?

While we are working to change these places into safe spaces there are measures we can take to protective our citizen safety. We are going to brainstorm strategies to keep safe in the community until we are able to make every place a safe space for girls, adolescents and women.

Write down the ideas on a flipchart. Make sure ideas do not tend to keep girls and women at home as a protection mechanism. Rather stimulate the group to think of ways that don't limit liberty and mobilization. 


\section{Application in daily life \\ Hand each participant a "Safe Spaces" worksheet. Tell the participants that} they should think about where they spend time. It could be in their house, school, with the Girls Creating Opportunities for a Brighter Tomorrow group, church or a friend's house. Of these places they should indicate: how safe do they consider the space? They will rank each place according to how safe they feel while they are there, marking one star if they do not feel safe, two stars if it is sometimes safe and other times not, three starts if it is always safe. For every place they can write what they would do with the space to make it safe and who they could work with to do this. To finish, open up the opportunity for participants to voluntarily share their answers with the group. The interesting part here would be to construct ideas of how they can go winning over safe spaces throughout the community. 


\section{Safe Spaces}

Write the places where I spend most time and rate their level of safety (1star-unsafe, 2-sometimes safe, 3-always safe).
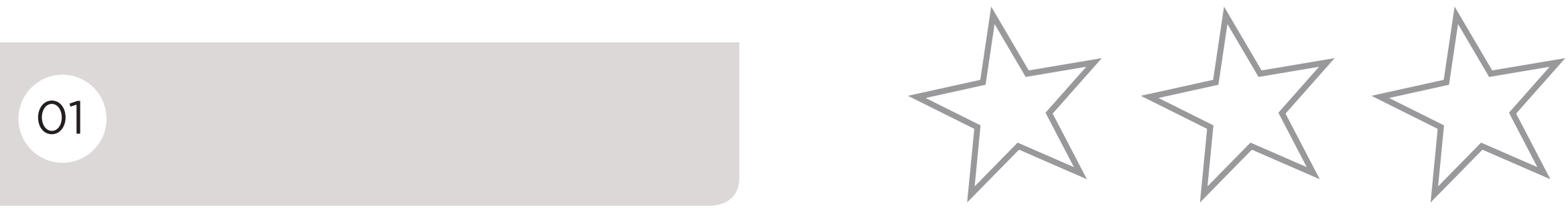

\section{2}
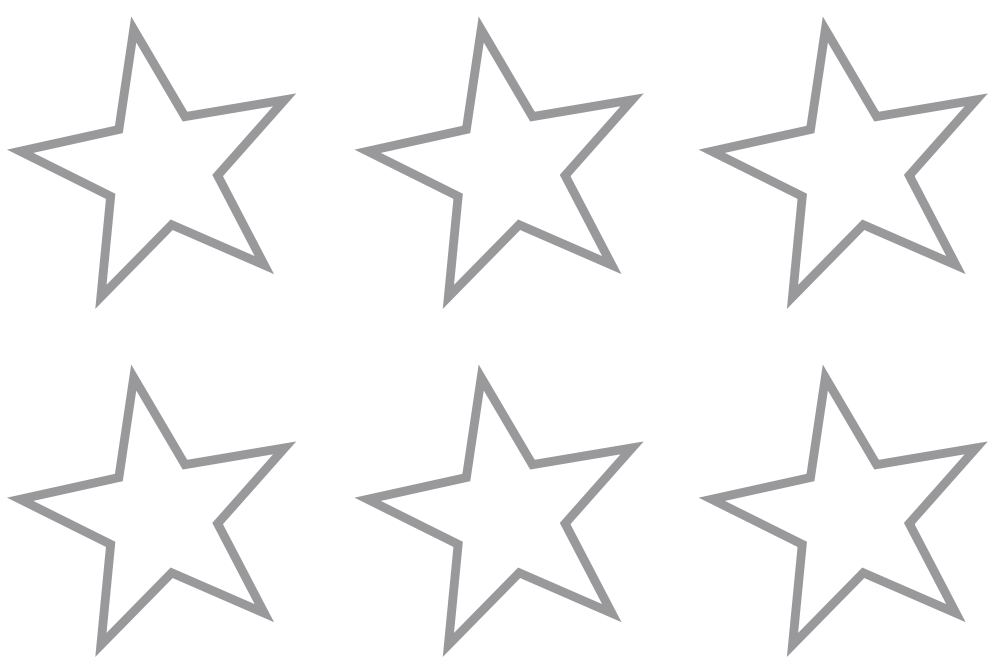

What can I do to make them safer for me and other girls in the community? Who can help? 


\section{2) Health: Nutrition}

\begin{tabular}{|c|c|c|c|}
\hline $\begin{array}{l}\text { OBJECTIVES } \\
\text { By the end of this session, participants } \\
\text { will have: } \\
\text { - Learned good nutrition practices. } \\
\text { - Learned the symptoms, signs and } \\
\text { effects of malnutrition. } \\
\text { - Gotten to know strategies to prevent } \\
\text { malnutrition according to the } \\
\text { nutrition pot. }\end{array}$ & $\begin{array}{l}\text { MATERIALS } \\
\text { • Flipchart } \\
\text { - Markers } \\
\text { - "Nutrition Pot for Belize" } \\
\text { • Worksheet }\end{array}$ & $\begin{array}{l}\text { TIME } \\
2 \text { HOURS }\end{array}$ & $\begin{array}{l}\text { KEY CONCEPTS } \\
\text { Nutritious foods: Need: Demand of } \\
\text { something that we are missing to } \\
\text { complete a goal, be well or survive. } \\
\text { Utility: Quality that satisfies a need. } \\
\text { Election: Choice made amongst } \\
\text { several alternatives according to our } \\
\text { needs and preferences. } \\
\text { Budget: Plan for income and } \\
\text { spending. } \\
\text { Satisfaction: Good sensation that } \\
\text { comes from providing, receiving or } \\
\text { consuming something that is needed. } \\
\text { Income: Money that we receive as a } \\
\text { gift or payment for a job. } \\
\text { Spending: Money that we exchange } \\
\text { for goods and services. }\end{array}$ \\
\hline
\end{tabular}




\section{Welcame}

Welcome the participants and take attendance. Ask how many of them feel like they have energy today, what they have eaten and what activities they have done today. See if they can successfully identify the relationship between what they have eaten and how they feel.

\section{Topic introduction}

Hand out half a sheet of flipchart paper to every participant and ask them to write or draw what they have eaten all day. They should do it individually, but while they work you can call out meals of the day to help them remember. Ask them to leave the papers on the floor forming a huge circle.

They should go around and look at all the other papers and dialogue about the community's intake by going through the following questions:

What do adolescent girls in the community eat the most?

What do they eat the least?

What is the most accessible thing to eat?

What would you like to eat more of, but is inaccessible?

Does everyone eat equally?

Is this food providing you enough energy for the amount of strength you put into your work and chores?

What happens when a child needs more energy for her body to continue growing, than she is receiving from the food she eats?

What symptoms of malnutrition do you remember?

\section{Theory and definition}

Explain to the group that it is important to eat food that provides energy, muscles, and vitamins. We can get all this from the foods that are naturally in our community, according to the nutritional pot designed especially for Belize. This proposal of food intake helps us make sure we are receiving what we need to develop and complete all the jobs that we have to do, as well as to grow and be healthy.
Handout the reading sheet "Nutritional Pot of Belize" and read the information together. They can comment about which foods are the easiest to find and how often they are eating them or not

\section{Tell participants:}

Our health and energy depend on what we eat and how we eat it. Eating is not the same as eating nutritiously. Everybody needs certain types of nutrients to be in good condition and we nourish ourselves with different foods to take advantage of the richness of the land.

Ask girls to compare the nutritional pot with their previous flipcharts documenting what they had eaten in a whole day. Give them markers so they can work on the charts to identify coincides and differences between both. Each participant will grade her nutritional intake according to who similar her flip chart is to the nutritional pot.

\section{Application in daily life}

Participants will work in couples to identify what they need to eat more of and what they need to eat less of. And then each girl will complete the "My Nutrition" worksheet. They can write what they are going to eat to take care of their bodies, why it is necessary to eat well and why they deserve to eat well. 


\section{Nutritious Foods of Belize}

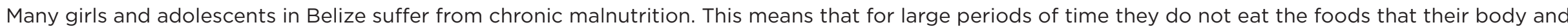

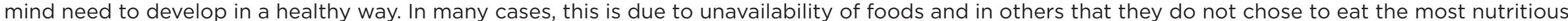

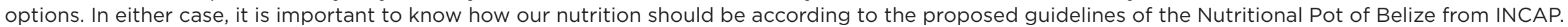

\section{Six Basic Food Groups and Frequency of Consumption}

Meat: at the least once a week

Greens and vegetables: every day

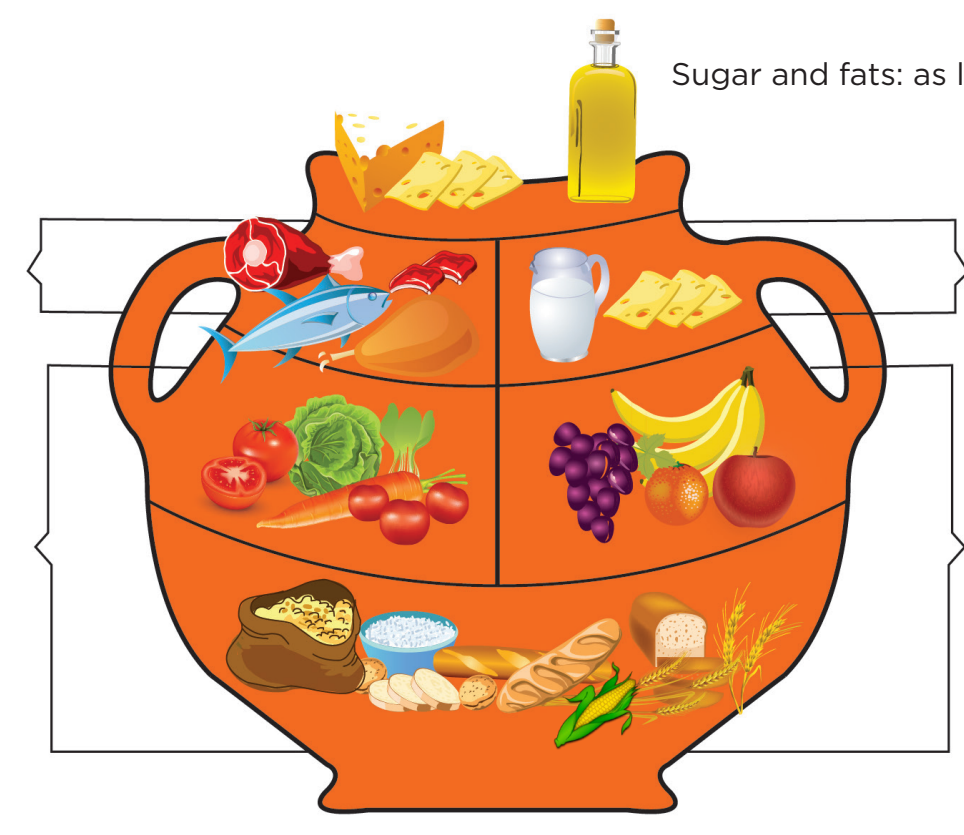

Milk and derivatives: at least twice a week

Fruits: every day

Grains, corn and

potatoes or casava:

every day

\section{Recommendations:}

1. Combine grains, cereals and potatoes in every meal.

2. Always eat greens and vegetables to strengthen your body.

3. Eat fruit everyday - whichever one it might bebecause they are healthy, good for digestion and nutritious.

4. Combine every tortilla that you eat with a spoon of beans. This is almost the same as eating a piece of meat.

5. Complete your diet by including an egg, a piece of cheese or glass of milk a few times a week.

To stay healthy always wash your hands and cover your food and water. 
'GIRLS CREATING OPPORTUNITIES FOR A BRIGHTER TOMORROW' PROGRAM

INTEGRATED CURRICULUM GUIDE

\section{My Nutrition}

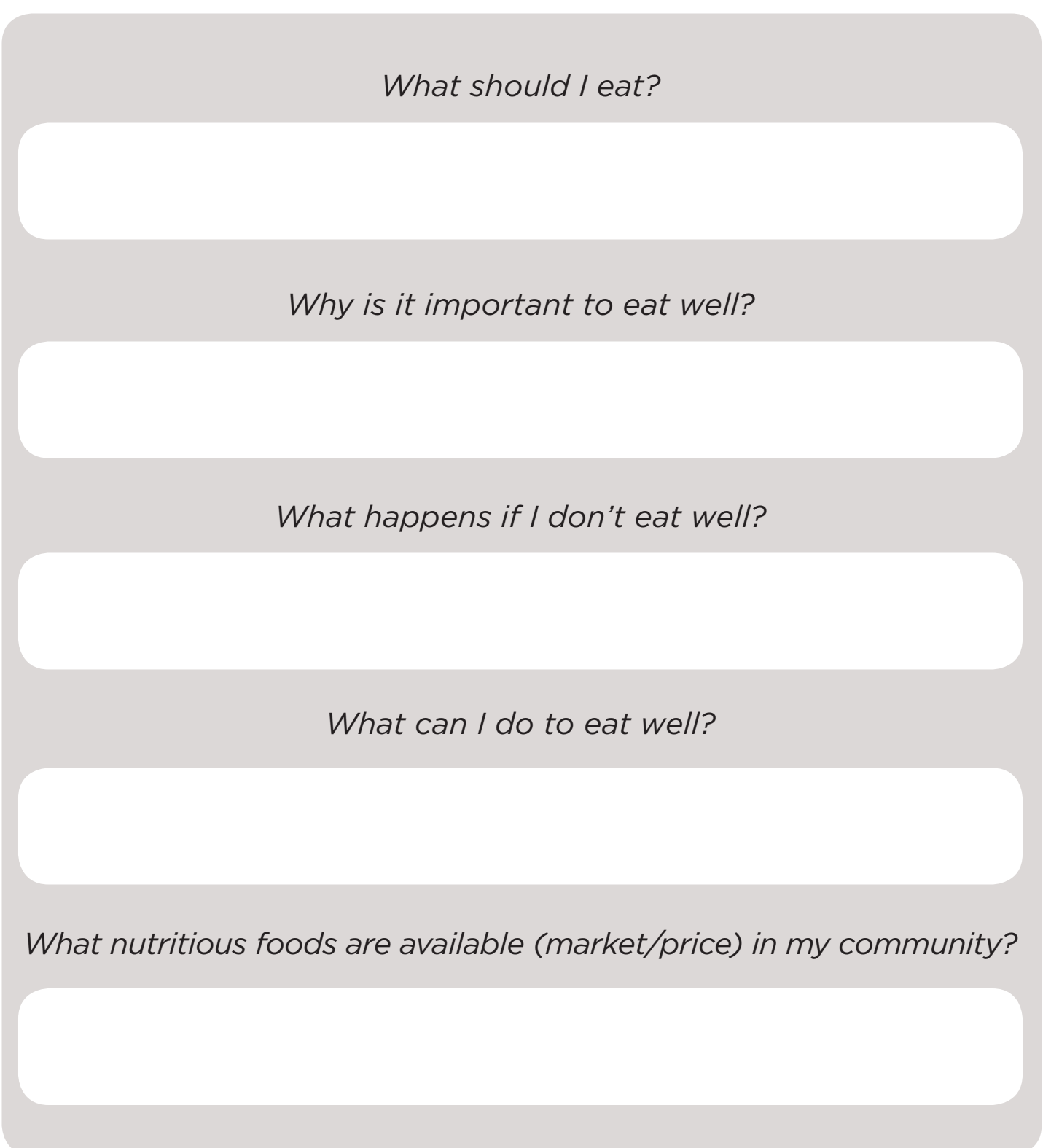




\section{3) Fertility, fertilization and pregnancy}

OBJECTIVES
By the end of this session, participants
will have:
- Learned the fertilization process that
leads to pregnancy.
- Discussed the myths and truths
about fertilization and pregnancy.
- Explained why women have the right
to decide how many, when and with
who they would like to have children.
- Identified that a woman can decide
to plan when to have, or not have,
children

MATERIALS
- Photos of ovaries, sperm,
ovum, ovum fertilized by
sperm and the
- Zygote implanted in the
uterus
- Large poster of female
sexual organs
- Flipchart
- Markers
- Signs with key concepts
for participants to see

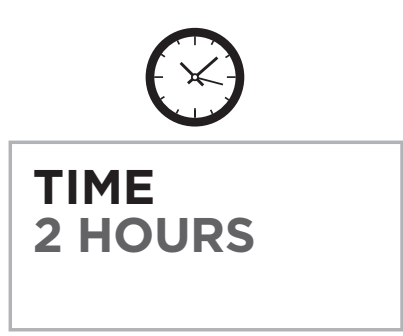

\section{KEY CONCEPTS}

Fertile period: Moment in the cycle when a woman can become pregnant from having sexual intercourse with a man.

Fertilization: Process through which sperm goes into the ovary, producing a fertilized cell that becomes a zygote, that embeds itself in the uterus and grows into a fetus.

Pregnancy: Nine-month period in which the baby is conceived, develops itself and is born. Also known as the gestation.

Zygote: The union between the ovum/egg and sperm from which a baby develops.

Ovum/egg: Female reproductive cells; found in the ovaries at the end of each fallopian tube.

Sperm: Male reproductive cells; found in a man's semen and deposited in the woman's vagina. 


\section{Welcame}

Welcome the participants and take attendance. Congratulate them for continuing to attend group. Ask if one of the girls has younger brothers or sisters and ask them to remember what it was like when their mother was pregnant, when she gave birth and the first few months after birth. Tell them that today they are going to learn more about the process and everything about how pregnancy happens.

\section{Topic introduction}

Begin by reviewing the names and locations of female sexual organs. Hang a poster with the names of the organs in the front of the room. Form 7 groups and handout a sign with the illustration of one of the organs: uterus, ovary, ovum, fallopian tubes, vagina, cervix, endometrium. In their groups, have them recall its name, where the organ is located and what its function is. Ask the groups to go up front and place the organ next to the corresponding name on the poster and explain the organ's function to the group. You should make sure that they are all correct and if there is an error take the time to clarify it in the moment.

\section{Ask the participants}

\section{Which organs are part of pregnancy? \\ Do you know what fertilization is?}

When does a women become fertile?

How does a woman become pregnant?

Where does the fetus develop during pregnancy?

\section{Theory and definition}

Explain to participants that fertilization is the name given to the union between the ovary and the man's SPERM. Ask what they know about men and fertilization, or about sperm. Allow them to share and take the opportunity to clear up any misunderstandings they might have.

Show them the image of a sperm and read the key concept of sperm for them. Then show the image of the ovum and read the key concept. Finally show them the image of a sperm entering an ovum and let them explain the relationship between the two cells.
Later explain that this union can only happen during the time of month known as the FERTILE PERIOD. Hang the sign with the definition of the fertile period in front of the group to read together.

Tell the group that when this union occurs there are no longer two independent cells. Instead they become one single entity known as a zygote. Show them the image of the zygote with the tittle and definition of zygote on the poster. Finish the brief explanation letting them know that during the 9 months, this cell grows and becomes a fetus that starts inside the uterus for 9 months and this time is known as pregnancy.

Show them the image of the fetus inside the uterus during development and pregnancy. Hang the definitions of the words in front of the group.

Tell them that you are going to explain the fertilization process in great detail along with how a woman becomes pregnant, so they should all pay close attention. Ask one girl to come up front and write the steps that you explain on a flipchart. While explaining every step of the process with the internal sexua organs on the poster, say to the participants:

1. During the FERTILE PERIOD of menstruation, the egg moves from the Fallopian tube towards the uterus.

2. At this time, the woman may have sexual intercourse and her partner's semen is deposited into her vagina. The semen has thousands of spermthe male reproductive cells.

3. The sperm swim quickly to find the egg that is in the Fallopian tube. The sperm try to enter in the egg all at the same time.

4. Only one sperm successfully penetrates the egg and together they form a zygote.

5. The zygote continues traveling from the Fallopian tube towards the uterus.

6. Once it is in the uterus, the zygote embeds itself in the endometrium. It attaches itself to the wall of blood that the uterus contains, which begins to give it nutrients and protect it.

7. The zygote grows there until it turns into a fetus with a brain, heart, limbs, eyes and all the parts of the body that we have. 
Ask the volunteer that has been writing the steps on the flipchart to share the seven steps to make sure she wrote them down correctly. If there is an error correct it in the moment. Ask them to form seven groups. Mix up sheets of paper with the numbers 1-7 on them and hand out one slip of paper to each group, along with a flip chart and markers. According to the number on their slip, they will draw the step of the fertilization process that corresponds to their group.

Group 1: Egg in the fallopian tube

Group 2: Semen in the vagina

Group 3: Egg and sperm find each other in the fallopian tube

Group 4: Sperm penetrate the egg and become one cell called the zygote.

Group 5: The zygote moves from the Fallopian tube towards the uterus.

Group 6: The zygote implants in the endometrium of the uterus.

Group 7: The zygote grows until it becomes a fetus and a baby at the end of the pregnancy.

After 10 minutes of group work, ask each group to come up and in order have them share the flip chart that they made and explain each step to the rest of the girls.

To finish, ask that each participant write the seven steps on a sheet of blank paper. They can draw the steps if they prefer. Ask them the following questions as a group to reflect:

What is the fertile period?

\section{The time that a woman can become pregnant.}

Where does the sperm find the egg during the fertile period?

\section{In the fallopian tube}

Where does the sperm come from?

The man's semen

How does the sperm get into the woman's vagina?

Through the semen that the man ejaculates into the woman's vagina during sexual intercourse

What is fertilization?

The moment when the sperm enters the egg.

What is the new cell formed from the union of the sperm and the egg called? Zygote
Where does the zygote get nutrients during pregnancy?

The endometrium, the bloody covering found on the wall of the uterus.

How long is the pregnancy?

9 months

What happens to menstruation during pregnancy? Why?

It does not happen because the fetus is protected by and getting nutrients

from the blood.

\section{Application in daily life}

Place two flipcharts in front of the group- one that says myth to the right and another that says fact to the left. Ask them to line up in between the two posters. Explain to them that you will be stating certain ideas about pregnan-

cy, men and women. The participants will jump to the right if they consider what you say to be a myth and jump to the left if they consider it is a fact. After each idea, you will say if it is a myth or a fact and offer more information about the topic. 


\section{Idea}

\begin{tabular}{|c|c|}
\hline When a girl has had her first period she can become pregnant if she has sexual int & FACT \\
\hline It is not healthy for a girl to bathe or swim during her period (menstrual period) & MYTH \\
\hline Not having sexual intercourse is the only $100 \%$ effective way to prevent pregnancy. & FACT \\
\hline $\begin{array}{l}\text { An adolescent needs permission from their parents to get information about how to } \\
\text { prevent pregnancy from the health center. }\end{array}$ & MYTH \\
\hline A woman cannot get pregnant if she has only had sexual intercourse a few times. & MYTH \\
\hline Vaginal douching after sexual intercourse prevents pregnancy. & MYTH \\
\hline $\begin{array}{l}\text { When a man is excited and has an erection he has to ejaculate because if he does not it will } \\
\text { hurt him. }\end{array}$ & MYTH \\
\hline $\begin{array}{l}\text { A woman cannot get pregnant if she has sexual intercourse but her partner does not } \\
\text { ejaculate inside her vagina. }\end{array}$ & MYTH \\
\hline A woman can become pregnant from her first time having sexual intercourse. & FACT \\
\hline $\begin{array}{l}\text { A man can cause a pregnancy from having sexual intercourse at any point in his life after he } \\
\text { begins ejaculating. }\end{array}$ & FACT \\
\hline You can prevent pregnancy through special methods. & FACT \\
\hline $\begin{array}{l}\text { A woman has the right to decide when, how many and with whom she would like to have } \\
\text { children. }\end{array}$ & FACT \\
\hline
\end{tabular}




\section{4) Sexual and Reproductive Rights}

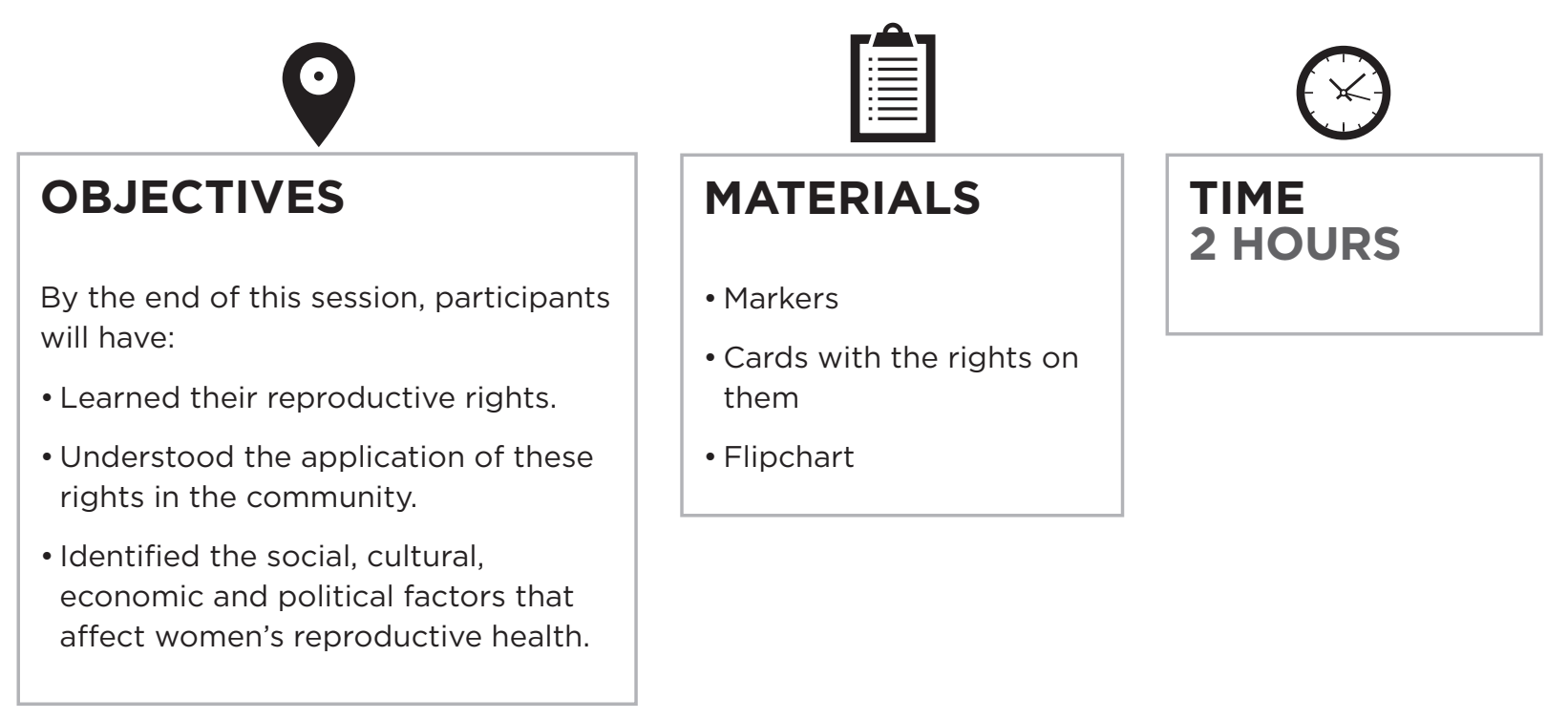

KEY CONCEPTS
Sexual and Reproductive Rights: A
group of rights that protect the sexual
and reproductive health of men and
women of all ages.




\section{Welcame}

Welcome the participants and take attendance. Ask how they feel today afte the last session about how a woman becomes pregnant and encourage them to ask questions related to the topic. Have them explain the process again helping each other remember.

\section{Topic introduction}

Ask the participants to get together into groups of three or four with their friends, randomly hand each group one slip of paper that names some people in the community:
a. Boyfriends
b. Husbands
c. Uncles
d. Cousins

\section{e. Family friends}
f. Step fathers
g. Teachers

Each group will make up a story of how a girl, adolescent or woman's sexuality can be hurt by that person. They must think of things that happen in the community. Finish up by having each group present their case to the rest of the participants

\section{Potential answers:}

\section{Ask girlfriends to prove love by having sexual intercourse.}

The husband does not use a condom.

The wife has sexual intercourse even though she doesn't want to.

The cousins abuse their younger cousins and touch her.

Mothers don't give information to their daughters about menstruation.

Uncles take advantage of their nieces...

After each group presents, ask the participants to make a rule that should be followed to protect girls, adolescents and women from this situation.
Write down their ideas on a visible flipchart. For example, instead of the first situation when a boyfriend asks the girlfriend to prove their love to them by making them have sexual intercourse, a rule could be: Nobody can make you have sexual intercourse. You can choose when and with whom you want to have sexual intercourse.

After making the rules for each scenario, explain that these rules already exist and they are called Sexual and Reproductive Rights.

5 Ask the group:

Why is it necessary to make up be sexual and reproductive rights?

Because they protect our sexuality and decisions about reproduction.

Who do these rights apply to?

Every man and woman, including us.

Would you like to get to know them? Do you believe they could help?

Yes. Getting to know them allows us to have more information to make better decisions, protect us and defend and distance us from people that might harm us.

\section{Theory and definition}

Share with the group that just like there are rights to protect nutrition, education and play, there are rights to product their health as well as sexual and reproductive health. Hand each participant a card with one of the sexual and reproductive rights on it. Ask them to read what is on their card aloud.

\begin{tabular}{|ll|}
\hline \multicolumn{1}{|c|}{ Sexual Rights } \\
\hline 1. & Right to decide on sexual preferences. \\
\hline 2. & Right to choose a method for family planning. \\
\hline 3. & $\begin{array}{l}\text { Right to practice sexuality without suffering discrimination, pressure } \\
\text { or violence. }\end{array}$ \\
\hline 4. & $\begin{array}{l}\text { Right to equality, mutual respect, responsibility and shared consent in } \\
\text { sexual practices. }\end{array}$ \\
\hline 5. & $\begin{array}{l}\text { Right to legal assistance in the case of sexual abuse, rape or sexual } \\
\text { assault. }\end{array}$ \\
\hline 6. & $\begin{array}{l}\text { Right to prevention, diagnosis and treatments for possible sexually } \\
\text { transmitted diseases. }\end{array}$ \\
\hline 7. & $\begin{array}{l}\text { Right to access education and information to decide and enjoy } \\
\text { sexuality, motherhood and fatherhood in a responsible way. }\end{array}$ \\
\hline
\end{tabular}




\section{Reproductive Rights}

1. Right to freely and responsibly decide about children: when, how many and with whom you want to have them

2. Right to scientific and understandable information concerning contraceptive options.

3. Right to have guaranteed access to various methods of contraception and to be able to freely choose which is preferred.

4. Right to a private, confidential, secure and respectful setting for consultations of personal health.

5. Right to humane treatment during pregnancy, birth and after birth

6. Right to prevention, diagnosis and treatments for possible sexually transmitted diseases.

7. Right to access education and information to decide and enjoy sexuality, motherhood and fatherhood in a responsible way.

After reviewing all the sexual and reproductive rights, ask them to get into groups of three and translate the three rights that they consider the most relevant for women in their community into their native language. Have them present to the entire group.

\section{Application in daily life Tell the following story: "The Life of Lupita"}

"Lupita was born into a family with six children: 4 boys and two girls. She was the fourth; she was also the smallest. Her family earned money growing and selling a little bit of corn. Frequently, there was not enough food for all the family. Like most families in her community, her father and brothers ate first; then her and her sister; finally, her mother ate. Lupita grew slowly and this was considered normal.

When she was six years old, Lupita began attending school. But, after two years she had to stop attending because there was not enough money to send all the children to school. Her two older brothers continued studying while
Lupita and her older sister stayed at home to help their mother take care of their younger siblings, do housework and grow corn.

When she was twelve years old, the family was in a better financial situation. They learned new agricultural techniques and were selling more corn. Lupita wanted to go back to school, but her father would not let her. The school was far away and he was worried for her safety. Also, he told his wife that Lupita would get married soon and it would not be necessary for her to have an education. Her older sister Maria who was 17 years old got married years ago and already had a child.

When she was 15 Lupita married Eduardo and went to live at his house. After four months she was pregnant and by 18 she had three daughters. She was always tired and her health was poor. Often she felt depressed and isolated. Even though she did not know how to read, she had heard talk of family planning. Many times Lupita hinted to Eduardo that she needed to rest. He got mad and hit her. Eduardo told her that she still had not given him a son. He also argued that family planning is not natural. Lupita, taking into account that he had scolded her, never talked about this again.

Lupita's health kept getting worse. She had gone to the doctor many times to be treated in her genital area. Every time the people at the local health center told her to use condoms to prevent diseases. But, Lupita thought that only prostitutes used condoms; moreover, surely Eduardo would reject using them. Lupita's fourth child was a boy and Eduardo was very happy. Now he was waiting for his second and third sons. Meanwhile, Lupita kept on feeling sad and tired."

\section{Ask participants:}

What are the situations in the story that went against Lupita's wellbeing and dignity? What factors contributed to Lupita's poor health?

Do you know women who live in the same conditions as Lupita?

Is a life like Lupita's acceptable? Why do you agree or disagree?

What can we do to make the lives of women better who have lived through the same experiences as Lupita?

Which of Lupita's rights have not been respected?

What rights do we have to work on more so that they are respected in this community? 
Before the next meeting, invite three or four notable women from

the community to present at the session so that they can share

their life experiences with the participants. Tell them that the

objective is to give the participants examples of other women who

have established and accomplished overcoming adversity that life

presents them. Hand out these questions to the invited women before the

session so that they can prepare themselves to meet the group.

- What life goals did you have when you were 13-18 years old?

- What goals have you achieved in your life?

- What steps did you follow to achieve that goal?

- What difficulties did you have to confront to achieve the goal?

- What strategies have you used to overcome the difficulties?

- In what other women have you found support?

- How have you supported other women?

- What right do you think should be protected for all women? 


\section{5) We are many diverse women working together}

OBJECTIVES
By the end of this session, participants
will have:
- Learned about notable women in
their community.
- Heard stories of notable women in
their community.
- Gotten to know strategies to
survive the challenges of life in the
community today.

\begin{tabular}{|l|}
\hline MATERIALS \\
- Markers \\
- Flip chart \\
- Name tags for guests \\
and participants \\
- Worksheet \\
\hline
\end{tabular}

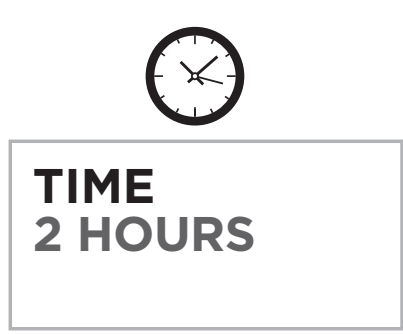

KEY CONCEPTS
Leadership: ability to lead, guide,
influence other people, teams and/or
organizations. People with leadership
have the potential to sponsor social,
cultural and economic development
within their community.




\section{Welcame}

Welcome the participants and take attendance. Share with the girls that today they are going to learn and discuss notable women in their community.

\section{Topic introduction}

Participants are going to meet some notable women from the community whom you have invited to the session. These are women who gone beyond community expectations, and have overcome challenges and reached personal or group goals. These women have been invited to share their experiences, goals, challenges and strategies to achieve success.

\section{Theory and definition}

Present the invited women to the group and share their name, something about their life, in what area they work and with which groups do they participate. Allow each invited woman to present herself to participants and invite them to share something brief about their life.

Form 3 or 4 groups (the same number as the guests you have) handing each group a question guide (like the one you handed to the guests) and indicating that they have 30 minutes to have a discussion with one of the guests. At the end each group will make a poster that presents the notable woman (including information from the question guide) and they will present it to the other participants.

Ask the participants:

What do you see that you have in common with these women?

What differences are there between these women?

What steps did these women take to achieve their goals?

What strategies did they use to survivor challenges and difficulties that they face?

Are these women an example of how we can support each other as strong and marvelous women?

\section{Application in daily life}

Invite participants to choose a woman who she identifies with- it could be one of today's guests or another woman that they know. Hand out the "Photo-Mirror" worksheet and tell the participants to draw the woman they admire on one side and draw themselves on the other. In the rope that brings them together, they will write how they contribute to the work being done by the woman she admires. 


$$
\square \square
$$




\section{MODULE 5}

\section{YEAR 2}

This module builds on three domains: financial education, violence prevention and community outreach. Participants will be enhancing financial literacy assets that support the exercise of their autonomy.

\section{Group ages 8 to 12}

5.1 Financial Education: I save money for my wellbeing

5.2 Financial Education: I save money for my wellbeing

5.3 Violence Prevention: I can make decisions to protect myself

5.4 Violence Prevention: Changing violence for respect between men and women

\section{Group ages 13 to 17}

5.1 Financial Education: Who pays for public services?

5.2 Financial Education: Financial credit: a matter of responsibility

5.3 Violence Prevention: In this community, we overcome obstacles

5.4 Violence prevention: Violence is fought with intelligence, courage and our friends

5.5 Community Outreach: Facing each other

5.6 Community Outreach: My community's needs 


\section{1) I save money for my wellbeing}

\begin{tabular}{|c|c|c|c|}
\hline $\begin{array}{l}\text { OBJECTIVES } \\
\text { By the end of this session, participants } \\
\text { will have: } \\
\text { - Learned about the benefits } \\
\text { of making saving a habit and } \\
\text { understood that in the future it can } \\
\text { help them achieve a goal. } \\
\text { - Understood that a saving habit is } \\
\text { important to build your assets. } \\
\text { - Known that different options that } \\
\text { exist to save and protect their } \\
\text { money: cooperatives and banks. }\end{array}$ & $\begin{array}{l}\text { MATERIALS } \\
\text { - Markers } \\
\text { - Flipcharts } \\
\text { - Sheets of white paper } \\
\text { - Pencils } \\
\text { - Cards with clues and } \\
\text { answers }\end{array}$ & $\begin{array}{l}\text { TIME } \\
2 \text { HOURS }\end{array}$ & $\begin{array}{l}\text { KEY CONCEPTS } \\
\text { Economize: Spend less money by } \\
\text { being an intelligent consumer. } \\
\text { Savings: Part of income that you } \\
\text { keep to use later- it could be for an } \\
\text { emergency or to achieve a personal } \\
\text { goal. } \\
\text { Savings Account: Contract between } \\
\text { a financial institution and a customer } \\
\text { in which the financial institution keeps } \\
\text { our money and gives us interest. } \\
\text { Bank: Financial institution that } \\
\text { receives our savings and lends money. } \\
\text { Assets: Things that are a person's or } \\
\text { family's property: house, animals, land. } \\
\text { Credit union: Financial institution } \\
\text { that offers financial services to its } \\
\text { members who are also owners. } \\
\text { Financial institution: Business } \\
\text { authorized by the government to keep } \\
\text { our savings: banks and cooperatives. }\end{array}$ \\
\hline
\end{tabular}




\section{Welcame}

Welcome the participants and take attendance. Ask girls if they have managed to save any money since they started in the program. Explain to them that they will listen to a story that will show them that money well spent is worth more than we can imagine.

\section{Topic introduction}

Participants are going to meet some notable women from the community whom you have invited to the session. These are women who gone beyond community expectations, and have overcome challenges and reached personal or group goals. These women have been invited to share their experiences, goals, challenges and strategies to achieve success.

Present them drawings of the following scenes from the story you will tell them:

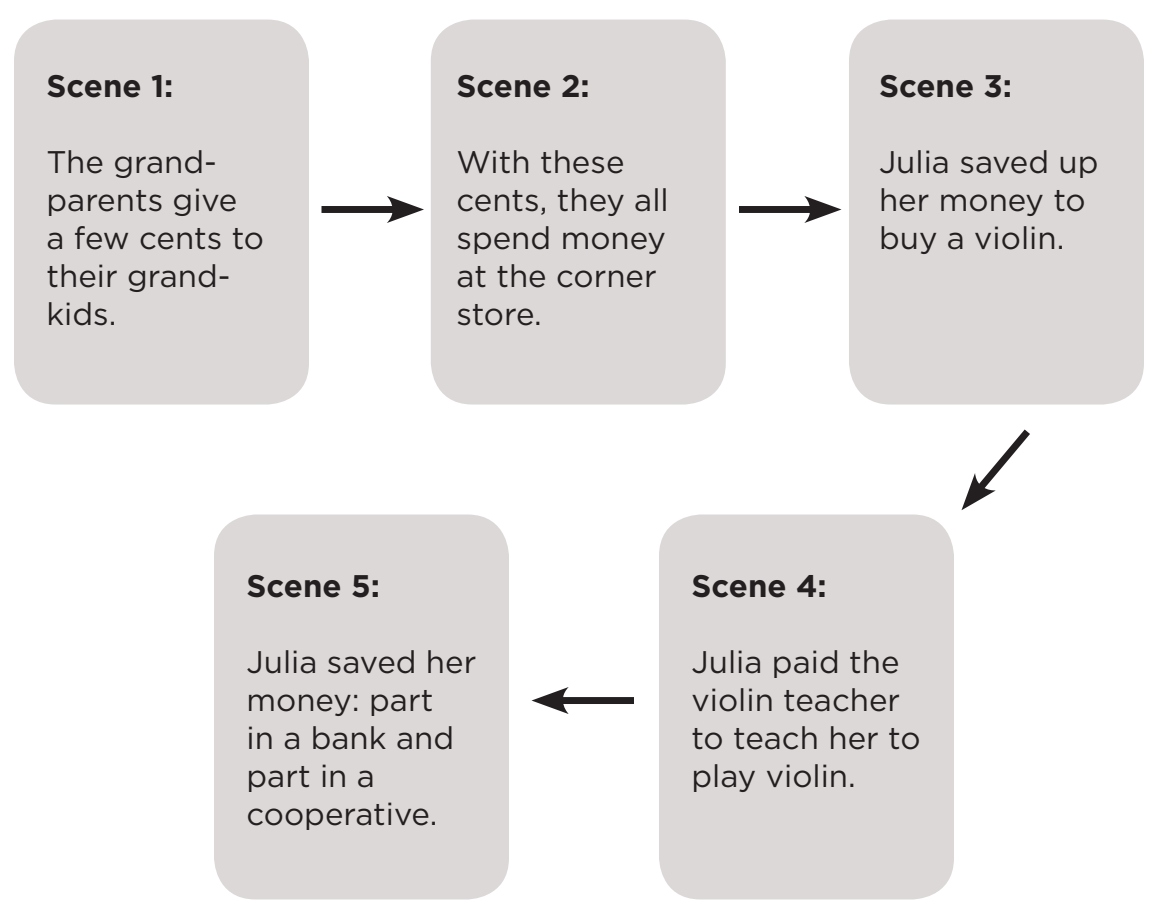

\section{Grandpa's coins}

Julia and her cousins were going to their grandparent's house excited because he would give them a few coins "to buy whatever they would like." So after the visit, all of the kids ran to the corner store to buy gum or sweets. Grandparents, uncles and fathers noticed that and understood kids would never learn to keep track of their money, so they proposed the children a special test: a competition to save during one year! This would show kids they were all capable of getting together more money.

Some of them suggested saving, but Pablo and Manuel, the youngest ones, did not pay any attention and in each visit they kept spending all their money on snacks. Rosi was a very precocious girl and decided to start making some changes like buying and selling things. In a short amount of time she surprised the entire family because she made a lot of money with little effort. But Rosi was barely careful, every time she got involved with riskier exchanges and a few months later she was left without even one Quetzal due to a bad business deal. That left Julia, who had a secret plan but was not able to save anything during that year.

When the second year was about to end, Julia surprised everyone by appearing in her grandparent's home with a violin and lots of money. Even more impressive was hearing her play it because she played very well, but the family was most excited listening to the little violinist's story. She told her family how she went to the park one day and offered the man who played the violin each of her grandpa's coins in exchange for violin lessons. It was a very poor payment but the man accepted and taught Julia how to play the violin. After some months, Julia began to play in the park with the man in exchange for money people gave them. In no time, Julia was able to by her very own new violin and save the rest in a bank while she continued to play in the park.

\section{Ask the participants:}

What did the older folks want their younger kids to learn?

What do you think the kids learned from this competition?

What made Julia's experience different from that of her cousin's?

What do you think about saving? 


\section{Theary and definition}

Play the "Financial Hangman" Handout cards with the answers to the participants and pile up the cards with clues in front of you. Draw one clue card and read to the participants. Whoever thinks she has the card with the correct answer she must come up to collect the clue card. If she is correct, she will draw the next clue card and read it to classmates. If she is not correct she will draw a part of the hangman and go back to her seat.

\begin{tabular}{|l|l|}
\hline Clues & Answer \\
\hline To save money & Savings \\
\hline Money that you receive & Income \\
\hline To spend less is & Economize \\
\hline Type of financial institution & Cooperative/Bank \\
\hline To keep... & To save \\
\hline House, animals, land & Property/assets \\
\hline $\begin{array}{l}\text { Safe place to keep your } \\
\text { money }\end{array}$ & Bank \\
\hline Spending is the same as & Buying \\
\hline $\begin{array}{l}\text { In the bank, money is kept } \\
\text { in a... }\end{array}$ & Savings account \\
\hline We save to have a better... & Future \\
\hline
\end{tabular}

Do a brainstorm with the girls about places where they could have a savings account and information they would like to receive about opening up a savings account.

\section{2) I save money for my wellbeing (part II)}

\section{Application in daily life \\ Begin by telling them Susan's story:}

Susan is a 10-year-old girl that lives in the Tierra Linda community. She already has big dreams of being independent so that her family has everything it needs. Every week her mother gives her a few leftover threads and Susan keeps them until she can make a belt to sell. She keeps the money she earned from the sales in a piggy bank. "When the piggy bank is full I am going to open a savings account" thought Susan when she put two quetzales in the piggy bank last week. For two days her little brother has had a fever and her parents need to find the money to buy medicine for him to get better. Susan very proudly and cooperatively offered her money from the piggy bank to cover the medicine. "Thank you Susan, how great is it that you saved and now you are helping us to overcome this hardship."

Ask the participants:

What is Susan's dream?

How does she use the threads her mother keeps?

could this be an example of savings?

Can you think of other things that people can keep or save?

Encourage girls to think of a goal or dream that they want to achieve. Then they should think about the things they could keep or save to achieve their goal or dream. Invite some participants to share their decisions about what they have to do to save.

Present the person you have invited to explain the savings plan, the advantages and implications of having a savings account. If there is not anyone close to the community, you could invite someone from the community who has a savings account. Develop a conference space so that they person can share information about ways to economize and save in their community. When the conference is over ask participants:

How will you save money?

What do you plan to use the saved money for? Which places can we save money in our community? 


OBJECTIVES
By the end of this session, participants
will have:
- Identified conflicts in the community.
- Recognized their right to protect
themselves and make decisions that
protect them.
- Learned the steps to making
decisions.

\begin{tabular}{|l|}
\hline MATERIALS \\
- Markers \\
- Stories \\
- Flipcharts \\
- Markers \\
- Sheets \\
- Community maps \\
\hline
\end{tabular}

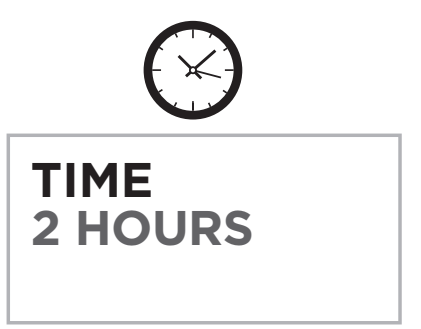

KEY CONCEPTS
Conflict: Situation that arises
when two or more interests are in
competition contradict each other
Decision: choice that is made when
confronting various options.




\section{Welcame}

Welcome the participants and take attendance. Share with the group that today we are going to be talking about the risks they find in their community and how they can make decisions that protect them.

\section{Topic intraduction}

Ask the participants to gather into groups and make a list of problems in the community that affect them. Ask the groups to share the problems while the mentor marks the places where these problems are on the map.

After marking all of the problems on the map, ask the group the following: Which of these conflicts affects you most directly?

How does it affect you?

What do you do when they go on?

Play the game "The Sheet with the 1,000 Knots." Present the girls with a sheet and tell them that this sheet represents their life. Like in all lives, the sheet has a conflict (while telling them this make a knot with the sheet). Pass the sheet to the first girl and tell her that her time has passed and since she did not solve the first problem the sheet now has two problems (ask the girl to make a new knot and pass it to another girl). She is confused and does not know what to do, so hasn't made a decision. Explain that a few weeks have passed and since the first two problems were not resolved it made a new one, adding up to four knots (have the girl with the sheet pass it to the next girl). Continue this game for five or six girls.

After finishing the sheet lead girls into making observations from the experience, ask:

How many conflicts does the girl have to solve now?

How many were there to fix at the beginning?

What would have happened if they had started to resolve to conflicts from the beginning?

How does the future of the girl look if she doesn't confront her problems and resolves conflicts?

How can making good decisions help solve conflicts?

\section{Theory and definition \\ Explain that:}

A problem is no more than a conflict with her personal interests and needs, that must be solved. Read the definitions of the key concepts from this session. When presented with a problem a person can take many paths. The most important thing is to make a decision and not wait for someone else to tell you that you have to do something according in the best interest of other people. When a problem comes up, making a decision will help us resolve the problem the best way possible and protect us from the risks it could bring.

Present a flipchart with the title: To make decisions that protect me....

\section{Ask:}

What is a decision?

What good decisions have you made in your life? How do you make a decision?

Write down the group's answers to this last question on a flipchart. Make sure to include the following ideas:

- Identify and understand the problem you are confronting

- Identify what is going to happen if you do not make a decision that protects you

- Identify options and alternatives you can take, and the results for each one.

- Identify the option that you consider to protects you best.

- Share your decision with a person you trust so that they can give you their opinion of your decision and support it with their advice

\section{Application in daily life}

Ask them to count off 1-4 and form four groups based on the number they got. Every group gets one of the following stories. Every team should read the situation they are given and identify: 
What risks are there for the girl?

What will happen if the girl doesn't make a decision to protect herself?

What options of actions does the girl have to look out for her protection?

What option protects her most and has the best possibility of working out?

What advice would you give about the decision she made?

They will present the case and answers, could be a skit or just sharing what they talked about in their group. The rest of the participants can suggest solutions for their group mates. Finish by asking:

Which of these conflicts do you think could happen to you?

What would be the most difficult to confront?

What would happen with your lives if you didn't confront it?

\section{STORIES}

1. I am 14 years old and my parents say that it would be better if I didn't study anymore because I can't learn anything and it's a waste of money and time. I get good grades and dream of going to the university to be a nurse.

2. I am already in high school, and I continue studying even though my parents do not want me to. My grades are good enough for me to graduate quickly. When I told my family that I want to go to college they tell me that there's no way because they don't have money. I looked into the possibility of a work scholarship. What do I do?

3. I started college, I live far away from my house and I have very little money. My boyfriend told me that I'm stupid for continuing to follow my dreams and thinks I am not going to make it. I can barely concentrate because of everything he says to me. Maybe he is right. What do I do?

4. I have some problems. I am pregnant but not married. The good thing is that I'm about to finish college and graduate as a nurse. I do not have money for this baby and I do not think that I want to stay with my boyfriend. He insists we get married and my family tell me the same. 


\section{4) Changing violence to respect between men and women}

\begin{tabular}{|c|c|c|c|}
\hline $\begin{array}{l}\text { OBJECTIVES } \\
\text { By the end of this session, participants } \\
\text { will have: } \\
\text { - Recognized different types of } \\
\text { violence and what they look like in } \\
\text { the community. } \\
\text { - Identified behaviors that are violent } \\
\text { because they negatively affect the } \\
\text { dignity and liberty of other people. } \\
\text { - Known the law to prevent, sanction } \\
\text { and eradicate violence against } \\
\text { women and similar legislation. }\end{array}$ & $\begin{array}{l}\text { MATERIALS } \\
\text { - Markers } \\
\text { - Brochures with the law } \\
\text { for each girl } \\
\text { - Flip chart } \\
\text { - Markers } \\
\text { - Props to use in the skit } \\
\text { - Worksheet }\end{array}$ & $\begin{array}{l}\text { TIME } \\
2 \text { HOURS }\end{array}$ & $\begin{array}{l}\text { KEY CONCEPTS } \\
\text { Violence: actions that go against } \\
\text { a person's dignity, limit her liberty } \\
\text { and deny access to opportunities for } \\
\text { development. } \\
\text { Domestic violence: What a member } \\
\text { of a family commits against another } \\
\text { family member especially when they } \\
\text { live in the same house. } \\
\text { Types of violence: Different forms } \\
\text { in which violence can be committed, } \\
\text { such as physical, psychological, } \\
\text { economic and sexual. }\end{array}$ \\
\hline
\end{tabular}




\section{Welcame}

Welcome the participants and take attendance. Share with the girls that today they are going to be working with the topic of violence, especially when it is against women, and they are going to learn about places where they can go to ask for help.

\section{Topic introduction}

They will do skits about behavior between men and women in the community that they feel affect them negatively and do not allow women to develop or be happy.

\section{Say to the participants:}

In the previous modules, we have worked on the importance of relationships and ideas on how people behave towards each other. Today you will be reporters for our local community press. You will be reporting on behaviors exist in the community and you do not like because they make

\section{Teaching Tip}

Go to each group and discuss the case they are planning to present. Make sure they have understood the exercise. Also make sure that the group will not share any personal cases or explicitly name girls/women who have experienced any kind of violence. you feel uncomfortable. When you see examples of this, you know that someone is being affected negatively, does not feel happy and cannot develop.

Make up four groups and assign to each group:

Group 1: report on a relationship likes this that you see in school.

Group 2: report on a relationship like this that you see at some homes.

Group 3: report on a relationship like this that you see at the crops fields.

Group 4: report on a relationship like this that you see at the park.

Give the group 30 minutes to prepare. First they will have to decide what they are going to act out and then prepare the skit. They can play as if they are reporters investigating a new story in that place. They should be creative, the important thing is to get to know what about the relationships provoke the girls to feel unhappy because they cannot develop and their freedom is limited.
After giving sufficient time, ask them to come together as a group again and make sure each group is ready to present. After each presentation ask the following questions, writing down their answers on a flip chart:

\section{What violent action is there?}

Between which people is it?

Who is the most affected?

How?

Are there others affected?

\section{Theory and definition \\ Explain:}

The examples that you all showed are violent behaviors that seem "normal" because they are part of the way people are treated in the community. The State of Belize or the representatives of this country have thought this is unacceptable and have made laws to protect us-especially women, adolescents, boys and girls- from the violence we can experience in the community. Today we are going to get to know these laws: The Domestic Violence Act, and the sections on sexual violence in the Criminal Law and the Gender Policy.

Hand each girl information about the law and the law itself if possible. Allow them to flip through it, seeing the others laws in the booklet as well. Have them comment on which articles grab their attention, which rights they already knew about and which are new. Explain that they are going to focus on the Domestic Violence Law and ask them to share what situations they know occur in the community that relate to the law.

Start by reading the Law and pause at the article that talks about types of violence.

Bring a flipchart with the name of each type of violence and an example of this violence. Ask them to give examples of these types of violence in the community and explain how these examples affect them. Continue reading the law very slowly and pausing to explain what the articles mean. They do not have to finish during this session. They should get to Article 3, which establishes who can report domestic violence. Pay special attention to the fact that they have the right to make reports and change relationships based on this law. 


\section{Application in daily life} Respect" let them work individually to draw one way they have been victims of violence committed by someone in their family. It could be their mother, father, brothers, sisters, cousins, grandparents, etc. Remember that a violent act is one that negatively affects a person, makes them sad and does not allow them to grow and develop.

\section{Teaching Tip}

Sharing personal stories as these has to be completely voluntary. Don't force

anyone to share! If you are up to it, share an example from your own life first.

Finish up by asking for some volunteers to share.

Before the next session (6.1) invite

community leaders that work on child

rights in the community to present to the group and

discuss the state of human rights in the community. Explain that you are going to ask them to present themselves stating their name, where they work and the child's right that they support along with answering the following questions: Why do they think this right is important? Whose rights in the community are the most at risk? What can boys do to help defend girls' rights? 


\section{Changing Violence into Respect}

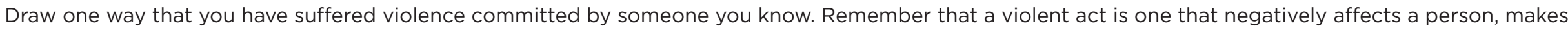
them sad and does not allow them to grow and develop.

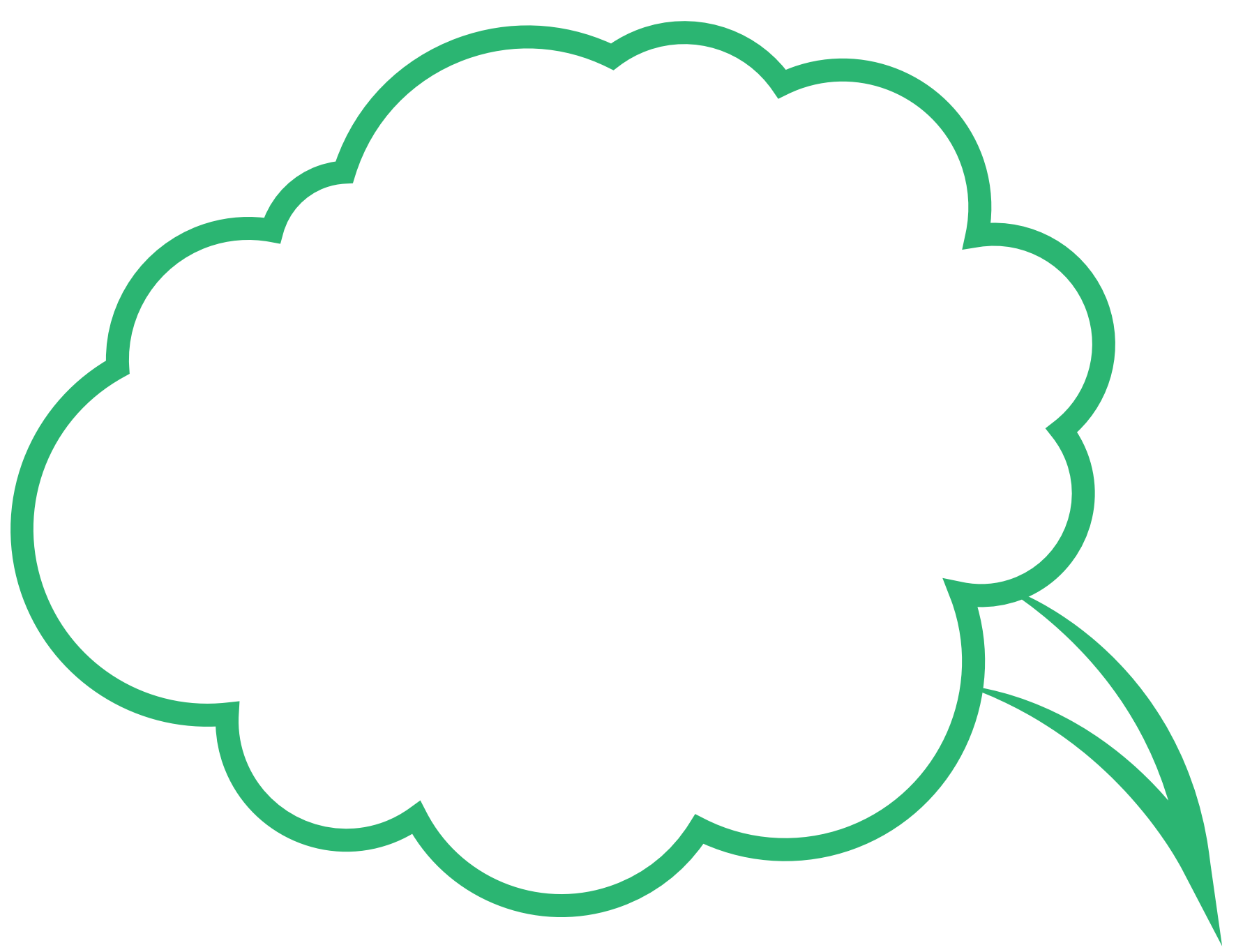




\section{1) Who pays for public services?}

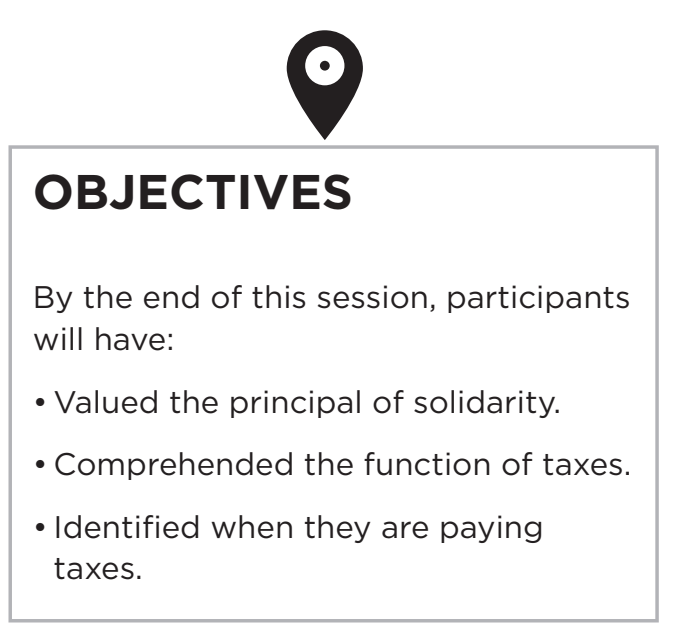

MATERIALS
- Newspaper
- Scissors and glue
- Cards with key concepts
- Pencil
- Reading sheet
- Notebook

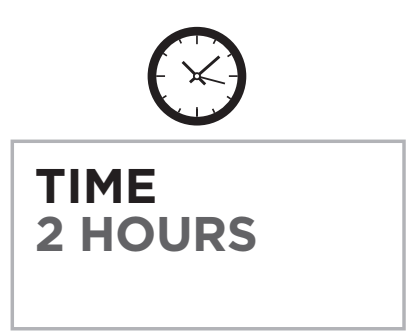

\section{, \\ KEY CONCEPTS}

Income Tax Department: Government office in charge of collecting taxes that the State receives.

The State: A bound territory, population and institutions of a country that are in charge of administration, justice and security.

Taxes: Contributions that people and businesses make obligated by law, so that the State has sufficient resources to provide the goods and public services that the country needs. When they are collected and administrated

well, taxes help redistribute the wealth of the country amongst the population. 


\section{Welcame}

Welcome the participants and take attendance. Invite participants for a walk around the community. They should bring one pencil and a piece of paper.

\section{Topic introduction}

Tell participants: In a country you can identify the following public services: Public lights, waste services, communal water, paved roads, police station, firefighters, health center, school, etc. With the money from our taxes, the municipality pays: public lights, pavement for streets, garbage collection, and the police force. These are all public services that benefit us and we pay for them all. The government collects the money and administrates it, but those who contribute the resources to pay for public services are citizens and all the businesses, through tax payment.

Leave the safe space with the participants and take a walk around the community. The goal is to go around and identify the different public services that exist. They can enter the municipality building or health center or the school office and ask the public servants about the service they offer and who is in charge of administration of the

offices resources. Let participants write down whatever they feel is important.

Ask the participants:

Have you heard someone talk about the taxes, their pay and its use?

What does your community not have, but need?

Would that be an example of public service?

Leave the safe space with the participants and take a walk around the community. The goal is to go around and identify the different public services that exist. They can enter the municipality building or health center or the school office and ask the public servants about the service they offer and who is in charge of administration of the offices resources. Let participants write down whatever they feel is important.

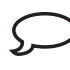

Ask the participants:

Have you heard someone talk about the taxes, their pay and its use?

What does your community not have, but need?

Would that be an example of public service?

\section{Theory and definition}

Back at the safe space, read through the reading sheet with the participants. While you are reading with them, underline the key concepts and most relevant information about the state and taxes.

Complete the "Today's News" activity: formed in 6 groups they will review newspaper searching for news and photos concerning actions that the government does thanks to takes. They will cut out and prepare a news display. Give each group one of the following messages and ask them to demonstrate how the news clippings relate to the message they have.

When human rights are fulfilled basic needs are met and society has a better chance for living in harmony and reaching higher standards of development.

Reciept: document that registers the purchase and the amount of money paid that corresponds to taxes.

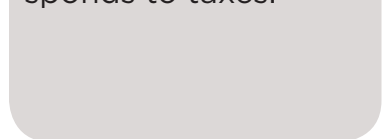

Government: group of institutions that are in charge of administration, security, justices and law within a country.

country.

Taxes: Financial contributions forcefully made by people and businesses so that the government has enough resources to offer services and development to the country's population.
Society must recognize that every person has rights and obligations with the state and that the state has the primary function of guaranteeing these are fulfilled.

\section{Income Tax}

\section{Department:}

The institution in charge of collecting

taxes for the

government.

After the presentations to go on to having group reading of the reading sheet. 


\section{Application in daily life}

\section{When do you pay taxes?}

What do you think about the use of taxes that you and your family pay?

What would you change about the use of taxes in your community?

We will make a list of 5 priorities you would like to have taxes invested to improve the lives of girls and adolescents in this community.

Why paying taxes and investing in the population that need the most support is a way of solidarity?

Ask them to brainstorm a large list and then work through it with them to choose the top five.

\section{The State of Belize, taxes and our rights}

The State of Belize is comprised by the territory, the institutions, the lay and the entire population. The government is part of the State: the ministers of education, health, the military, the advocate for indigenous women, the schools, the health centers, the police, judges and Income Tax Department offices. The State of Belize has accepted the challenge and responsibility to make sure that your rights are respected.

How does the State guarantee my rights? For example, when a school is built, or a teacher is payed it is guaranteeing your right to an education. When a health center receives you and a doctor examines and provides you medicine, it is guaranteeing your right to health. The goods and services provided by the State are called public goods and everyone has the right to access and use them. No one can be excluded or discriminated against when using them The quantity and quality of public goods and services cannot be decreased due to the amount of people entitled to them.

But, where does the government get its money? Remember when you learned how to make your budget? The government does its' own budget every year. The income is made up of taxes and financial contributions made by international cooperation. And expenses include salaries for employees, public buildings, hospitals, police departments, public electricity, innovation in services, justice services etc.

Now we will talk about taxes. Taxes are contributions that all people and business should pay. We are obligated by law so that the government has suffi- cient resources to provide the public goods and services that the community needs. Taxes are important because:

- The government can obtain the resources it needs to be able to provide education, health, security, justice, public works and support to the needy, among other things.

- They help further equality in opportunities.

- It is a form of participation in community matters.

Receipts are invoices when we buy something with cash or credit. For example, when we make purchases we pay the value of the merchandise plus taxes and we are given an invoice for the total. The tax that we are charged should be paid by the business to the State, through the SAT. Receipts are very important because:

- They are legal documents that establish a relationship between buyer and vendor.

- They provide details about the operation completed.

- They backup and register the operations that the business performs.

- They provide support to register the business' operations.

- They allow the Income Tax Department to monitor quality control after the business operation.

Asking for a receipt is a right that we all have when we make purchases. It is an obligation or responsibility of the seller. 


\section{Financial credit: A matter of responsibility}

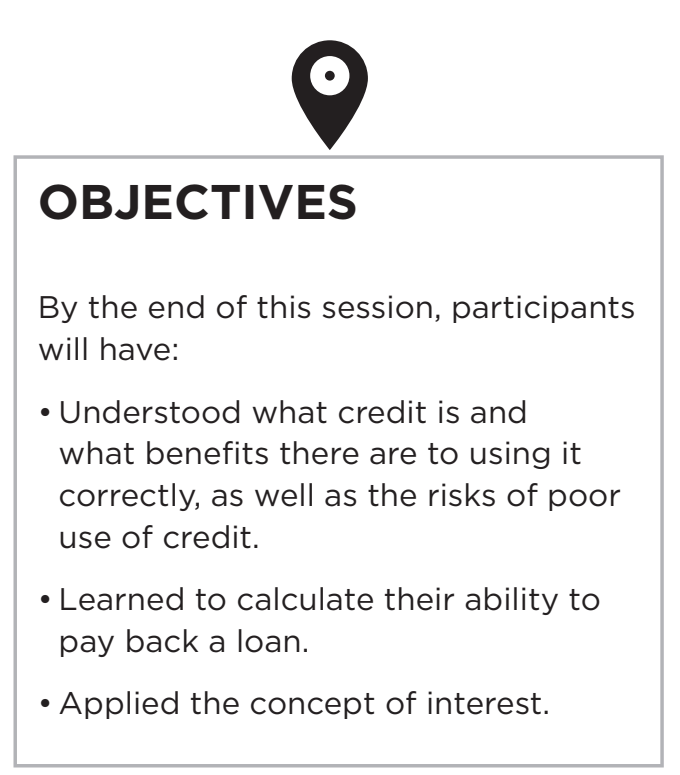

\begin{tabular}{|l|}
\hline MATERIALS \\
- Flip chart with examples \\
of the "Yat and Choc \\
family budgets" \\
- Slips of paper to sort \\
them into families \\
- Puzzles with key \\
concepts \\
- Blank sheets of paper \\
- Reading sheet
\end{tabular}

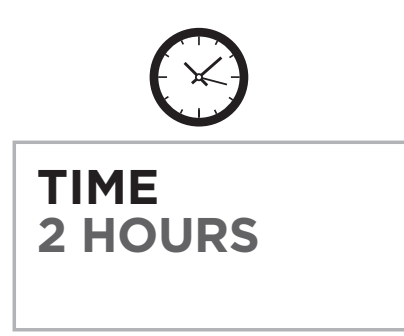

\section{KEY CONCEPTS}

Credit: Loan that has to be paid back with interests in a determined period of time.

Capacity to pay: The amount of available funds from our income after all expenses are done.

Credit history: Register of all loans we have solicited, along with how and when we paid them.

Interest rate: Percentage that we have to pay in addition to the amount lent.

Credit card: Used to buy something paid with the bank's money. If you spend, but do not pay by the date that the bank demands the money, you pay the amount of the purchase plus interest.

Deficit: When we pay out more than we receive.

Surplus: When we spend less than we receive and have extra money. 


\section{Welcame}

Welcome the participants and take attendance. Share with them that today we are going to learn about how credit works.

\section{Topic introduction}

Read the following story to the participants:

One afternoon, Doña Natalia was walking on the main street with her daughter Sonia when they passed in front of a store that sold things for the house.

- "Mama, look! Here is the furniture that you wanted and it is on sale in six payments if you pay with a credit card! Can we buy it with your card? You have a lot of money on it," said Sonia.

- "No, the credit card isn't my money: it is a loan from the bank that I have to pay back with interest," her mother answered.

- "Interest?" said Sonia

- Interest is money that the bank charges for loaning me money on the credit card.

- Ok, don't confuse me. Do you have enough money for the furniture or not?

- It is important to know that we can pay this debt...

- But if I heard you right, what you said to papa is that with a loan we could even pay for a house. Why aren't we going to buy the furniture?

- This is where problems start Sonia. If we buy a lot of things and we spend more than what our income allows, later we won't be able to pay, said Doña Natalia.

- And what? Either way we would have the furniture ...

- It is not that simple. It is like when Aunt Eugenia asked to borrow from everyone and afterward she didn't pay. Do you remember?

- Uff, yes. Now nobody loans her money. Even grandma and grandpa hide from her. I am starting to understand...but are we going to give up the sale? It says here that its six months with no interest. Is that saying that the bank isn't going to charge you for borrowing money?

- Yes. But if we do not pay money we will have to pay interest. That's why before buying it we have to go to the house and calculate with paper and pencil to figure out our capacity to pay.

- "Ay mama, I want a credit card. That way I can buy more things" insisted Sonia.
- No, credit is a loan that you have to pay. This means there is responsibility. You can have a card when you are older and you have an income from your job that allows you to pay for what you buy.

Ask the participants:

What is credit for?

What happens if we ask to be loaned money and later we do not pay? What does it mean when we say "we can pay"?

\section{Theory and definition}

Write each key concept on a sheet and cut them up to make puzzles. Form seven groups and hand out a puzzle to each group. Ask them to put the puzzle together and paste it on a sheet of blank paper. Afterwards ask each group to present the topic that they were given. Go through the reading sheet with participants.

\section{Aprlication in daily life}

Have them form pairs and assign them to the "Yat family" or "Choc family". Present the flipcharts with example of budgets for each family.

\section{Choc Family Budget}

\begin{tabular}{|l|l|l|l|l|l|}
\hline & Week 1 & Week 2 & Week 3 & Week 4 & $\begin{array}{l}\text { Monthly } \\
\text { Total }\end{array}$ \\
\hline Income & Q700.00 & Q700.00 & Q700.00 & Q700.00 & Q2,800.00 \\
\hline Expenses & Q600.00 & Q520.00 & Q630.00 & Q580.00 & Q2,330.00 \\
\hline $\begin{array}{l}\text { They have a } \\
\text { surplus and } \\
\text { have enough } \\
\text { money }\end{array}$ & Q100.00 & Q180.00 & Q70.00 & Q120.00 & Q470.00 \\
\hline
\end{tabular}




\section{Yat Family Budget}

\begin{tabular}{|l|l|l|l|l|l|}
\hline & Week 1 & Week 2 & Week 3 & Week 4 & $\begin{array}{l}\text { Monthly } \\
\text { Total }\end{array}$ \\
\hline Income & Q700.00 & Q700.00 & Q700.00 & Q700.00 & Q2,800.00 \\
\hline Expenses & Q550.00 & Q725.00 & Q775.00 & Q710.00 & Q3,060.00 \\
\hline $\begin{array}{l}\text { They have } \\
\text { a deficit } \\
\text { and do not } \\
\text { have enough } \\
\text { money }\end{array}$ & Q150.00 & Q25.00 & Q75.00 & Q10.00 & Q260.00 \\
\hline
\end{tabular}

According to the family that they were assigned, have the girls answer the following questions:

Is there a surplus or a deficit?

What expenses could be reduced so that the money is balanced?

How much money could they save per month?

Does the family have the conditions to receive a credit or loan?

\section{Credit a matter of responsibility}

Credit is an amount of money that we receive with the obligation to pay it back within a certain amount of time, along with interest. It is a tool that allows us to acquire goods and services, some that we could not acquire quickly without credit. For example, it is easier to buy a house on credit than with cash because we would have to save for a long time to be able to pay for a house all at once. But credit and loans can also get us into trouble if we are irresponsible with them: if we take out loans that we can't pay or if we don't pay over a period of time, our finances will be affected, we end up paying much more than what we received and we lose the opportunity to get more loans in the future.

Before asking for a loan, we should evaluate if we can pay it. That is why we need to know what part of our income we can put towards paying the loan. We can get to know our capacity to pay by subtracting our expenses and our income, including the amount that goes to pay other debts and savings. What remains is the maximum amount that we can put towards paying a new debt without the risk of not being able to make the payments.

Just like we compare prices when buying a television, it is also convenient to compare different options of credit. The price of a loan is its' interest rate. This is the money that we should pay for receiving a loan and it is in addition to the amount we borrowed. The higher the interest rate, the more expensive the loan or credit will be. Before signing a contract for a loan, it is important to analyze the various options and identify which will charge the lowest interest. The way that we pay back our loans is registered, and it shows whether we pay on time, late or if we don't pay at all. This log is called a credit history. A good credit history can open doors for future loans or credits, but a bad history can close doors because nobody wants to lend to someone who does not pay it back.

Different types of credit exist. Business credit is credit we request to make an investment and start a business. For example, a business credit or loan allows us to buy products to open up a convenience store or buy a taxi. A home loan or mortgage allows us to buy a house or land and pay it back little by little. When we use the loan to buy goods or services to satisfy our everyday needs, we are talking about consumer credit.

A commonly used form of credit is the credit card, which is a form of payment in which we can make purchases from commercial establishments without carrying cash. When we get a contract for a credit card, the bank lends us up to a certain amount of money known as the credit limit. If we use this money, then we have to pay it back along with the corresponding interest. It is important not to confuse a credit card with a debit card. 


\section{3) In this community, we overcome obstacles}

OBJECTIVES
By the end of this session, participants
will have:
- Identified conflicts in the community.
- Understood conflict is an opportunity
to improve a situation.
- Learned resolution and negotiation
strategies.

\begin{tabular}{|l|}
\hline MATERIALS \\
- Worksheet \\
- Stories \\
- Flipchart \\
- Markers \\
- Crayons
\end{tabular}

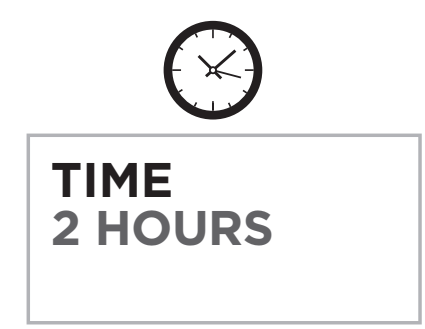

KEY CONCEPTS
Conflict: A situation that happens when
two or more interests collide.
Conflict resolution: Human capacity to
give answer to situations of conflict that
arise.




\section{Welcame}

Welcome the participants and take attendance. Ask them to share a bit about a good experience they had recently where they solved a problem.

\section{Topic introduction}

Ask the participants to get into groups of four and draw a map of the community, then to identify areas where there are conflicts. Invite them to think about conflicts in the family, school, municipality, government offices, streets, the market, bank, sports fields, etc. After 20 minutes ask them to come back to the group and present their maps while you write down a list of the conflicts that happen in the community on a flipchart.

Explain that conflicts are real and have always occurred. Review each conflict with them and try to cover as many conflicts as possible. Ask the group the following:

\section{Since when has the conflict happened?}

What did it come from?

Who is involved in the conflict?

Who is affected by the conflict?

How does conflict affect the entire community?

Has there been efforts to solve the conflict?

\section{Theory and definition}

Ask the participants to translate the key terms into their language. After that discuss what strategies there are to resolve conflict and which are used the most frequently in their community. Do the "Giving and Giving" activity to see that there are forms of conflict resolution and above all, that the solution for the conflict can contribute to everybody's human rights being respected.

\section{S Say:}

So that people can resolve conflicts and enjoy their rights as much as possible without affecting

the rights of other people, many times negotiation is necessary. Negotiation is when two or more people want different things and they talk about how to come to an agreement so that they can find a solution that everyone agrees with. To do this, every person should have certain attitudes. You have negotiated when bargaining to buy something or when asking for permission. What should a person do to negotiate?

\section{Listen to what everyone else says and what they are asking for.}

\section{Respect opinions.}

Understand that you are not always going to have everything just like you want it.

\section{To give or make something in exchange the other person must also give or} do something.

Write down the answers on a flipchart including:

Ask them to give examples of when they have negotiated and have them explain why a negotiation could be thought of as a "Win-Win" situation.

\section{Application in daily life}

Ask them to count off 1-4 and form four groups according to their numbers. Each group is assigned a story on the worksheet, "Overcoming Obstacles." Each team should read and analyze the case answering on the flipchart:

Who are the parts in conflict?

What rights are being put at risk? What does each part of the conflict want? How can the woman negotiate?

What should she request from or give up to the other party?

After 15 minutes they will present to the entire group through a skit or just sharing their thoughts. The rest of the participants can contribute more solutions. To finish up, ask:

- What new conflicts can come up from these stories if they don't confront and resolve the current conflict?

- What opportunities might come out of negotiating these conflicts?

Teaching Tip
Participants will have this
as a first opportunity to
think of their life plan.
Explain a bit about life
plans and make sure they
know there are several
issues to be included in
their plans.


- Which of these conflicts do you believe could happen to you?

What would be the most difficult part of

confronting it?

- What would happen to your lives if you didn't confront it?

How would you negotiate?

Ask them to complete the "Overcoming Obstacles II" worksheet. 


\section{Overcoming Obstacles}

I am 14 years old and my parents say that it would be better if I didn't study anymore because I can't learn anything and it's a waste of money and time. I am expected to stay at home and help my mother in the house. I get good grades and dream of going to the university to be a nurse.

I started college, I live far away from my house and I have very little money. My boyfriend told me that I'm stupid for continuing to follow my dreams and thinks I am not going to make it. His father spoke to mine and they are willing to set a date for our marriage, because my dad needs help in the fields and he would do that. What do I do?
I am already in high school, and I continue studying even though my parents do not want me to, they believe I risk my security and if anything happens to me I better be ready to get married. My grades are good enough for me to graduate quickly. When I told my family that I want to go to college they tell me that there's no way because they don't have money. I looked into the possibility of a work scholarship. What do I do?

I have some problems. I am pregnant but not married. The good thing is that I'm about to finish college and graduate as a nurse. I do not have money for this baby and I do not think that I want to stay with my boyfriend. My mom says she wants me back at home and will be glad to take care of her granddaughter. My brother, says he won't be willing to feed another mouth in the house so we're not welcome on his account. What do I do? 
'GIRLS CREATING OPPORTUNITIES FOR A BRIGHTER TOMORROW' PROGRAM

INTEGRATED CURRICULUM GUIDE

\section{Overcoming Obstacles II}

Plans that I have

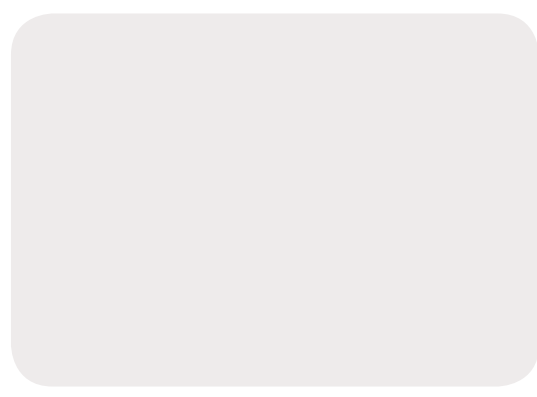

Possible Obstacles

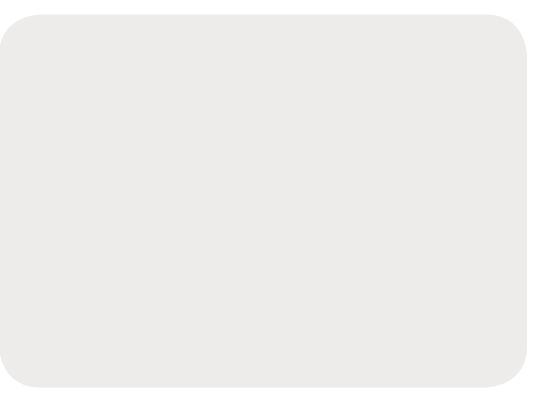

What can I do? 


\section{Violence prevention: Violence is fought with intelligence, courage and our friends}
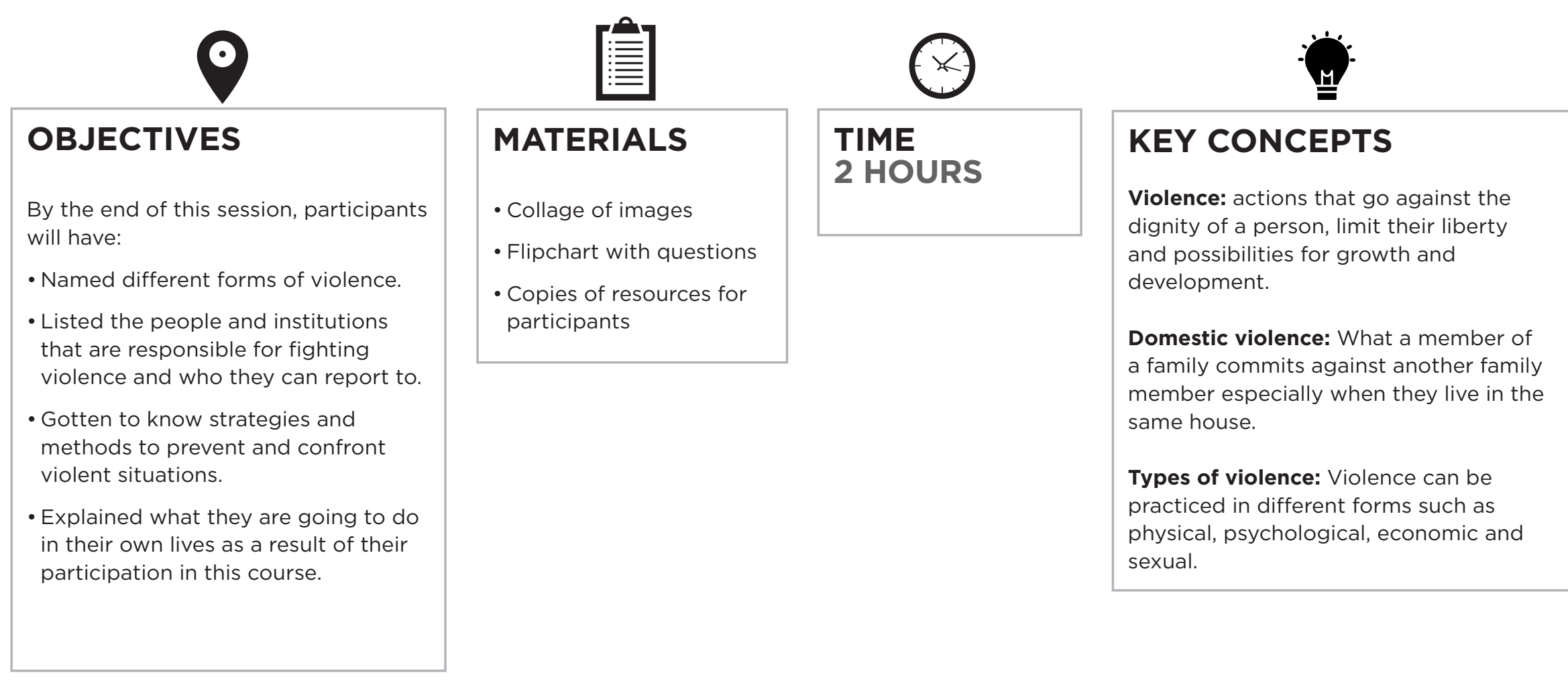


\section{Welcame}

Welcome the participants and take attendance. Share with them that today they are going to work on the topic of violence, especially violence against women, and they are going to get to know the places where they can ask for help.

\section{Topic introduction}

Bring with you a collage of newspaper clipping of women who have suffered violence. Make sure to include examples of all types of violence. Allow the participants to have time to come up and see clippings. Ask them to discuss following questions in groups of four.

Ask:

What violent actions are occurring?

How is the life of a woman affected by this violence?

Are there similar cases of violence in your community?

Why can poverty and hunger be considered forms of violence as well?

After going through all of the groups, explain that violent actions can come in many forms and affect victims in various ways. Ask each group to discuss an example of violence that they know and make a drawing of it on a sheet of paper. Encourage them to look for different things, not the common examples. On the back of the drawing they should write the answers to the questions that you bring written on a flipchart before the group meets.

\section{Who is committing the violent action?}

Who is the direct victim?

Are there are victims affected by the violent action?

How does violence limit the victim's development and opportunities?

\section{Theory and definition}

Hand each girl the supporting material that you have about violence in the country. Along with the reading ask some of the following questions:

What relationship is there between health and violence?
How does violence affect the health of a woman, adolescent girl and a young girl?

How do the experiences of women in your community compare with what is defined as violence?

Share the following statistics doing a representation exercise. Put the facts on a flip chart and then play with them. To complete the exercise, ask 10 volunteers to come up front. After reading each statistic the volunteers will represent the women who have been hit by placing a mark on their face or another part of their body to symbolize the violence they suffered according to the statistic.

\begin{tabular}{|l|l|}
\hline Statistics & Exercise \\
\hline $\begin{array}{l}\text { 1. Around 40\% of women in Mexico } \\
\text { have suffered violence in their homes. }\end{array}$ & $\begin{array}{l}\text { For the first line ask } 4 \text { of the } 10 \\
\text { volunteers to take a step forward } \\
\text { and give them a mark to represent } \\
\text { the violence. }\end{array}$ \\
\hline $\begin{array}{l}\text { 2. In Chile, 50\% of women have suf- } \\
\text { fered violence at the hands of their } \\
\text { partner. }\end{array}$ & $\begin{array}{l}\text { For the second and third lines, ask } \\
\text { one more to take a step forwards } \\
\text { and give them a mark to symbolize } \\
\text { violence. }\end{array}$ \\
\hline $\begin{array}{l}\text { 3. In Nicaragua 50\% of women have } \\
\text { been hit by their spouses. }\end{array}$ & $\begin{array}{l}\text { For the fourth line ask four girls } \\
\text { that are not up front to come up } \\
\text { and insult four of the five that have } \\
\text { suffered violence and place a } \\
\text { broken heart on } 4 \text { of the } 5 \text { girls. }\end{array}$ \\
\hline $\begin{array}{l}\text { humiliated. } \\
\text { balmen that suffer physi- }\end{array}$ & $\begin{array}{l}\text { For the fifth line, ask that from the } \\
5 \text { volunteers that have been hit, } \\
\text { two lay down on the floor to } \\
\text { represent sexual violence. }\end{array}$ \\
\hline $\begin{array}{l}\text { 5. Nearly } 40 \% \text { of women hit by their } \\
\text { partners have also been forced to } \\
\text { have sexual intercourse with them. }\end{array}$
\end{tabular}

Open up the spaces for their comments about violence. They can begin to give some ideas about what they learned up to know about violence. Write down their ideas on a flipchart.

Form three groups and hand each group one of the following laws: Political Constitution of the Republic, Law of Integral Protection of Childhood, Law to prevent, sanction and eradicate domestic violence, Law against femicide and other forms of violence against women, law against sexual violence, exploita- 
tion and trafficking of people. Ask them to identify what institutions and people are responsible for helping to combat the violence and have them write it down on a flipchart. Afterward they should present to the group.

\section{Application in daily life}

Ask them to get into groups of four and hand out brochures, fliers and sheets that have information about what a person can do if they are suffering vio-

lence. Ask them to read The information in their group and write down a plan of action that identifies:

- Types of violence that girls and adolescents in your community can suffer

- Where the violence happens and who commits it

- Institutions where you can ask for help and are obligated to change the violent actions

Motivate girls to come early to the next topic session to meet public servants in their community. They can make the invitations for public servants in their next handicrafts session. 


\section{5) Community outreach: Facing each other}

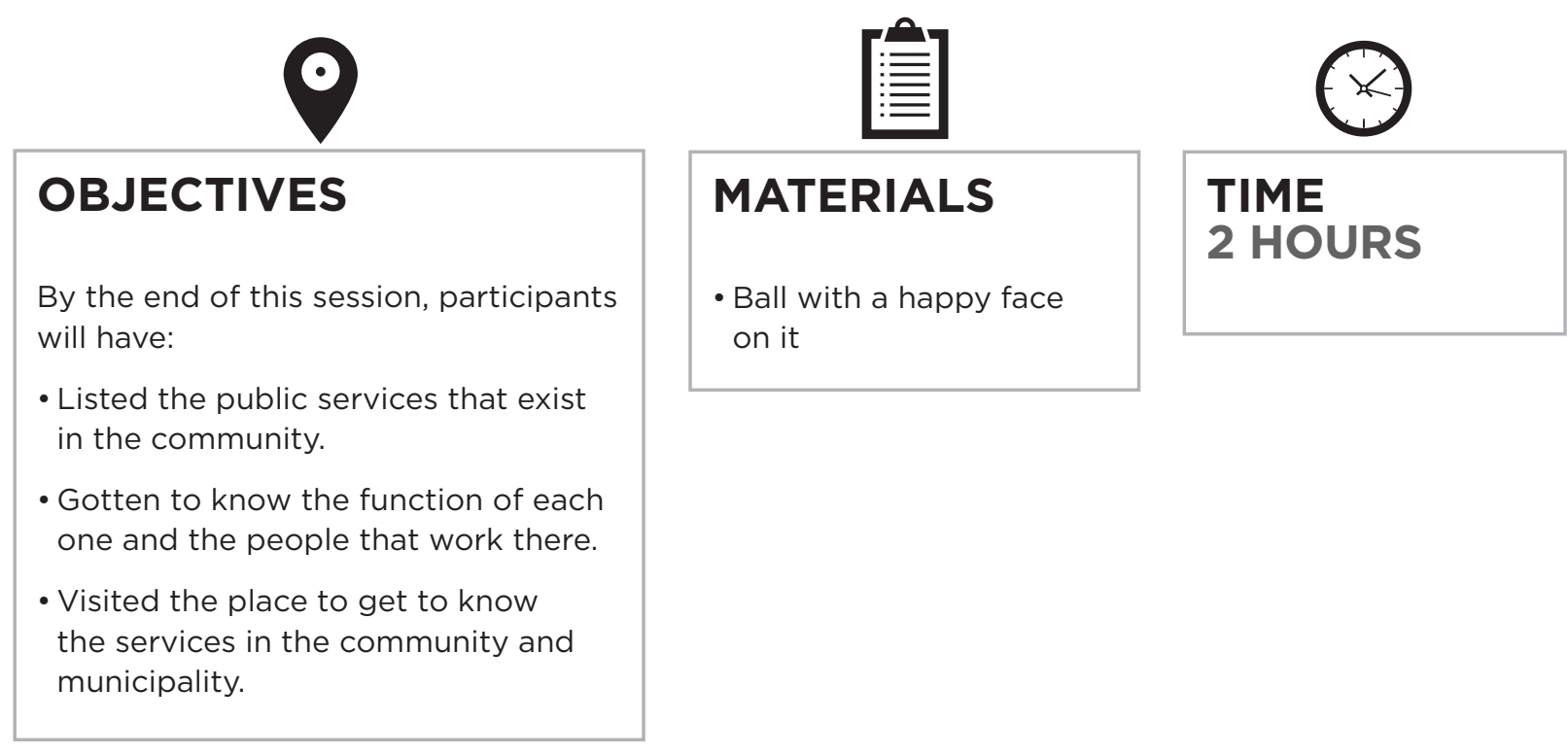

KEY CONCEPTS
Public Service: Service that the
government offers all citizens
guaranteeing rights and development
of the population.
Public Servant: Person that works in a
governmental office.




\section{Welcame}

Welcome the participants and take attendance. Share with them that today we are going to learn about people that help the population from the public service sector and are responsible for taking care of citizens' rights. Ask that the participants be ready to receive the invited guests and when they arrive to have them help seat each one and hang up a nametag with their name.

\section{Topic intraduction}

Ask the guests and participants to form a large circle together they will hold onto the sheet. Tell them that the ball represents them and that they are responsible for not allowing the ball to hit the ground by using the sheet. They will lift the sheet up and move the ball from one point to another. Throw the ball in the center of the sheet and encourage them to play and move the ball to its goal. If there are many participants, they can do the exercise in two groups and make it a competition between them to see who can move the ball to the goal without dropping it.

S After playing, ask the participants:

\section{What happened with the ball?}

What would have happened with the ball without the sheet?

What would happen if a part of the sheet had wholes or if someone on the team dropped the sheet?

How can we compare the sheet to the people that help us reach our goals? When have you felt that you need the help of a community organization?

What community institutions do you know that you can ask for help?

$$
\text { S Say: }
$$

In this community there are various people that work to serve the population and today we have the pleasure of some of them accompanying us. I am going to present each person that accompanies us by saying their name and where they work.

After completing the presentation form groups of participants to work with each civil servant. Give one girl from each group a questions guide so she can stimulate conversation between the servant and the group. Allow for them to dialogue in their groups.

Everyone will return to their initial places and allow some participants that want to share to say something positive about what they have learned. Finally thank the invited guests for their time and attendance. 


\section{6) My community's needs}

OBJECTIVES
By the end of this session, participants
will have:
- Learned about objectives of
sustainable development.
- Identified the community's needs.
- Prioritized a need that they would
like to work on.
- Contacted a person from their
community that works on the need
that they selected.

\begin{tabular}{|l|}
\hline MATERIALS \\
- Markers \\
- Drawings of people in \\
the community \\
- Flyers with information \\
about Sustainable \\
Development Goals
\end{tabular}

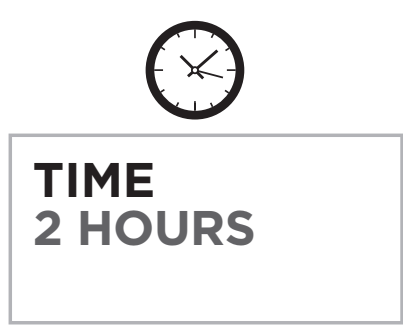

\section{, \\ KEY CONCEPTS}

Goals of sustainable development (SDG's): Goals that international institutions have agreed upon that all countries should meet within the next 15 years to end poverty, fight inequality and injustice, and confront climate change. 


\section{Welcame}

Welcome the participants and take attendance. Share with them that today they are going to begin to think about their community and the needs it has by considering what humanity has proposed as the minimum conditions of life that we should achieve for all people.

\section{Topic introduction}

Play the guessing who! Divide the girls into 9 groups and hand each one sheet of paper with a drawing of a person from the community. Ask them to make up a riddle about the person. They will present it to the group to play guess who?

After all of the groups present, ask:

What needs does everyone have in common?

What rights are not guaranteed for these populations?

\section{Theory and definition}

Explain that just like the world made goals about which rights to respect, more recently they made goals related to conditions for a good life that everyone should have by 2030 . We are going to read about this together. Read the definition of the key concept.

Hand each participant a flyer with information about the Sustainable Development Goals.

S Ask:

Which group of people do you think is prioritized in this community? What efforts has the community made in the past few years to reach this goal?

What efforts have other people made to achieve this goal? What goal would you personally like to help achieve?

What would we ask from the COCODE?

\section{Application in daily life}

Each participant is going to circle which sustainable development goal they want to work on and what needs the community has related to this objective.

They should get to know someone inside or outside of the community that works on this objective or resolves the needs necessary to achieve it. The girl should read the sustainable development goal that she wishes to work on and ask them:

\section{What do you do to achieve this goal?}

Why is your job important?

What characteristics are required for someone to have this job?

What satisfaction does the job bring?

In the following session they should bring their work and turn it in to their mentor. They will be reviewing these again during the next trimester.

ASK PARTICIPANTS TO BRING INTERVIEWS TO THE NEXT SESSION AND GATHER THEM. THEY WILL BE USED IN SESSION 6.4 

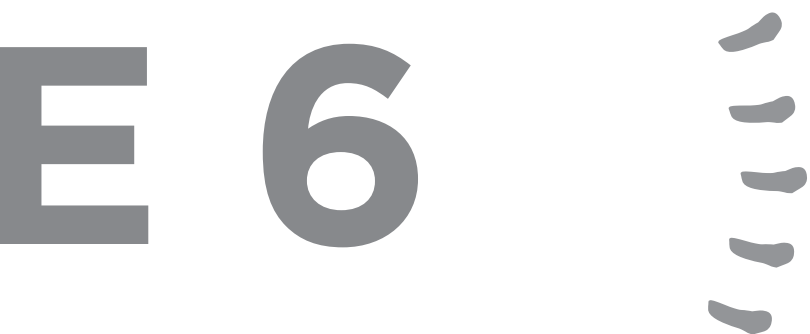


\section{MODULE 6}

\section{YEAR 2}

Girls Creating Opportunities for a Brighter Tomorrow concentrates the final period on enhancing assets that allow girls and adolescents develop their life plans. The group takes a deeper look into sexual health and reproductive health as well as personal strengthening as issues that will foster their ability to decide about their own life. Through community awareness they will be sharing their plans and assets with community members to stimulate their image as young girls and adolescents with that contribute to their families and community, and have the right to education health and participation.

\section{Group ages 8 to 12}

6.1 Community outreach: Girls' rights in my community

6.2 Personal strengthening: My community's needs

6.3 Community outreach: I imagine what I can accomplish in my life

6.4 Community outreach: My gift to the community

\section{Group ages 13 to 17}

6.1 Sexual and reproductive health: I make my own decisions

6.2 Sexual and reproductive health: Learning about STI's and HIV/AIDS

6.3 Sexual and reproductive health: Family planning

6.4 Community outreach: I am a contribution to development

6.5 Community outreach: My life plan and my contribution to the community 


\section{1) Girls' rights in my community}

OBJECTIVES
By the end of this session, participants
will have:
- Graded access that they have to their
rights.
- Named people they can ask for help
in the community to take care of the
rights of girls and boys.
- Gotten to know people in their
community that work with human
rights.
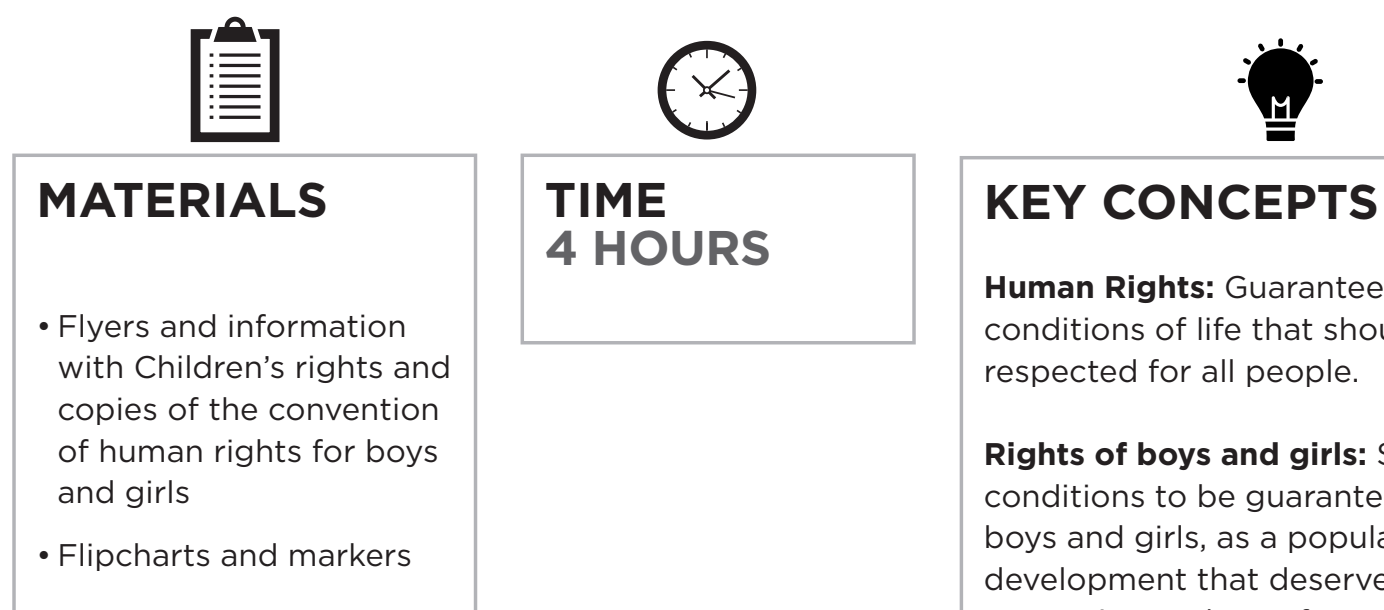

Human Rights: Guarantees for conditions of life that should be respected for all people.

Rights of boys and girls: Specific conditions to be guaranteed for boys and girls, as a population in development that deserves special protection and care from adults. 


\section{Welcame}

Welcome the participants and take attendance. Congratulate them for getting to the last phase of the program guide and allow them to share how much they have learned and what they want to do to use that knowledge now.

Let them know that this module they are going to dedicate themselves to looking into their community and thinking how everything they have learned can be used to make life better. Ask them to walk around the room thinking about a person in the community that they admire. They are going to bump into a friend and look at each other and share who the person is that they admire in the community.

\section{Topic introduction}

Show the participants the information on Children's rights and the copies of the convention of human rights for boys and girls. Discuss how these rights look in each of their own personal lives and that of their communities. Ask them to make a drawing of this.

S Ask:

Do you know stories from people, families or communities that had to flee from the places they lived?

How was life for them?

Do you know families that have migrated recently?

How is life for the family members that stay?

Who are family members leaving their community?

\section{Theory and definition}

Explain that they are going to form groups of 4 or 5 participants and say:

Imagine that you all are leaders in a community and you want everyone in this new community to live a good life so that they are happy and have everything they need to live and develop. In groups you should write down the $10 \mathrm{~min}$ imum conditions of life for everyone in the community that must have and everyone must respect.

Give them 10 minutes to write this list. Have them share their list. Hand out material with the right of children and read with them. Then ask:

\section{Do you know the rights of boys and girls?}

How does your community uphold the right that corresponds to your group?

When don't they uphold it?

What do adults do to make sure this right is upheld?

\section{Application in daily life}

Tell participants that have a visit from

people in the community that serve in leadership positions and whose job is supports and makes the community better. Have them help to seat each one and hang up a nametag with their name. The rest of the participants should be seated in front of the invited guests' seats.

S Say:

In this community there are various people that work to serve the population and today we have the pleasure of some of them accompanying us. I am going to present each person that accompanies us by saying their name and where they work. They are going to tell us about the children's right that they support, as well as tell us a little bit about:

Why do they think this right is important?

Who in the community is at the greatest risk for not having their rights upheld?

To wrap up, thank the invited guests for their attendance and time.

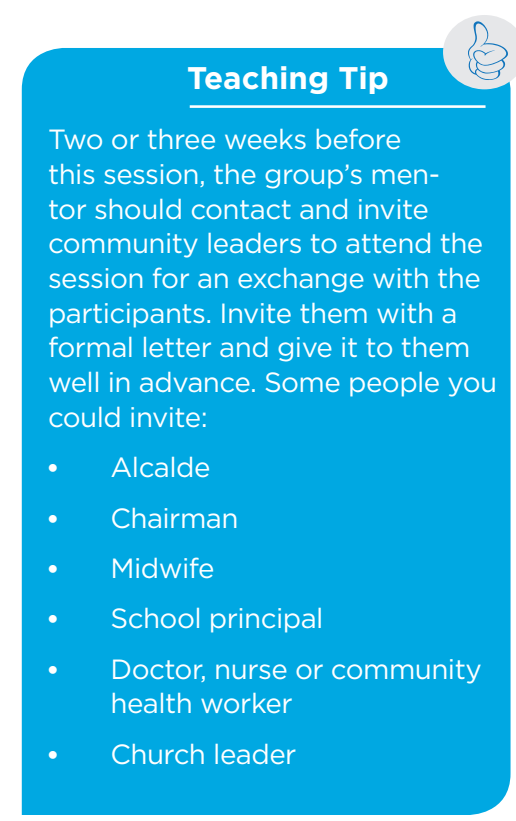




\section{2) My community's needs}

\begin{tabular}{|l|}
\hline OBJECTIVES \\
By the end of this session, participants \\
will have: \\
- Learned the objectives of sustainable \\
development and human rights. \\
- Identified the community's needs \\
in relation to the objectives of \\
sustainable development and human \\
rights. \\
- Prioritized a need that they would \\
like to work on. \\
\hline
\end{tabular}

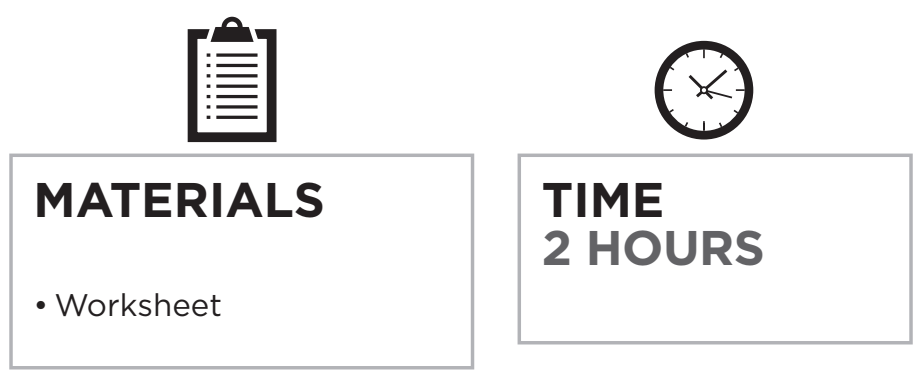

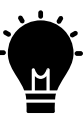 \\ KEY CONCEPTS}

Goals of sustainable development (SDGs): Goals that international bodies have agreed upon that all countries should meet within the next 15 years to end poverty, fight inequality and injustice and confront climate change. 


\section{Welcame}

Welcome the participants and take attendance. Share with them that today they are going to be think about their community and the needs it has by considering the goals that the world has proposed need to be achieved by 2030.

\section{Topic introduction}

Play Guess who! Hang up a flipchart with the list of the following populations in the community on the wall and explain that you are going to say a few things about what this population needs and they should guess which group you are referring to. Hang up a flipchart for each group so that everyone can see them.

Babies: They need milk, their families to take care of them all the time, diapers, coats.

Boys and Girls: They need nutritious food, they need books and pencils start school and learn to read and write, they need a family to care and love for them, need time to play and have fun.

Adolescents: They need nutritious food, need time and places to get to know themselves and their peers well, need information to make decisions about their life and family planning and how to prevent pregnancy and STIs. Adult Pregnant Women: They need nutritious food, medical attention for their babies before, during and after birth, need to work and feed their children.

Afterwards ask:

What needs does everyone have in common?

What rights are violated when these needs are not met?

How are your lives affected when these needs are not satisfied?

What problems does the community face so that it can satisfy all the needs?

\section{Theory and definition}

Explain that just like the world made goals about which rights to respect, more recently they made goals related to conditions for a good life that everyone should have by 2030 . We are going to read about this together. Read the definition of the key concept. Hand each participant a flyer with information about the Sustainable Development Goals.

\section{Ask:}

Which group of people do you think is prioritized in this community?

What efforts has the community made in the past few years to reach this goal?

What efforts have other people made to achieve this goal?

What goal would you personally like to help achieve?

\section{Application in daily life}

Each girl will draw which Sustainable Development Objective interests her most on the worksheet "Shared Goals." 
'GIRLS CREATING OPPORTUNITIES FOR A BRIGHTER TOMORROW' PROGRAM INTEGRATED CURRICULUM GUIDE

\section{Shared Goals}

Draw what you would do in your community when you support the Objective that interests you. 


\section{3) I imagine what I can accomplish in my life}

\begin{tabular}{|l|l|l|}
\hline OBJECTIVES & $\begin{array}{l}\text { By the end of this session, participants } \\
\text { will have: }\end{array}$ \\
- Understood what human \\
development is and how you reach it. \\
- Written a life plan by considering \\
their personal goals and what they \\
can contribute to the community. \\
- Proposed actions that they could \\
take inside their community to \\
improve human development.
\end{tabular}




\section{Welcame}

Welcome the participants and take attendance. Share with them that today they are going to identify how valuable each of them is to the human development of their community. Start by recognizing the qualities and strengths that they have and can put forth towards the development of the community by playing "The Bottle of Good Things."

Sit the participants in a circle and place the bottle in the center. Ask that someone begins by spinning it and when the bottle stops they are going to tell the participant that it is pointing to: what strength she has and how she could use it to contribute to the development of the community. Then she spins the bottle and it goes on until everyone has gone and have said a quality and how it can be contributed to the community.

\section{Topic introduction}

Ask each girl to identify a phrase that makes her feel like she is marvelous, has so much to give and she can make decisions about her own life. To encourage the conversation and reflection, you can ask:

What have you learned from the program, your peers and the visitors that have come?

How can a person's job change something in the community?

What things do you believe you can do to improve life in the community?

\section{Theory and definition}

Read the definition of Human Development that is in the key concepts and tell them to remember which qualities of sustainable development interest them. Participants think of themselves as both responsible for, and contributing to, the achievement of the goals and improved development in the community. But, we are going to start with our families, schools and friends.

Explain:

From when a person is born, they have the possibility and right to make decisions about what they want to be and do in their life. Often we live our lives, we are born and die without thinking about this. What do I want to be and what do I want to do with my life? What am I good at? How can I contribute? How can I achieve that?

\section{Application in daily life}

This is exactly what you are going to think about today as well as during the next session. Each one of you has strengths to support your life and improve the life of the community. Thinking about your strengths and the goals and needs of the community each one of you will silently answer the following questions on the worksheet "I am already contributing."

What need or goal do / think is important to achieve? What strengths do I have to support my family? How can I help achieve goals in my family, school and friends?

Allow time so that they can work individually on the worksheet. Tell them that they can draw or write but the most important thing right now is to think about their own lives and the values that they have. 
'GIRLS CREATING OPPORTUNITIES FOR A BRIGHTER TOMORROW' PROGRAM

INTEGRATED CURRICULUM GUIDE

"I Am Already Contributing" 


\section{4) My gift to the community}
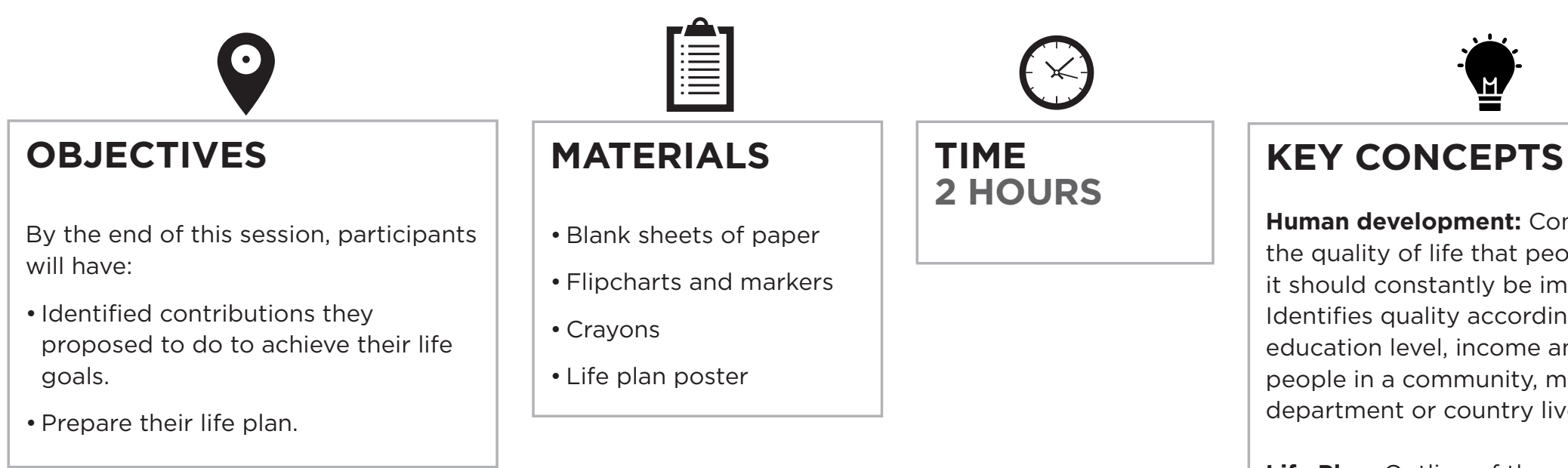

Human development: Considered the quality of life that people have, it should constantly be improving.

Identifies quality according to

education level, income and years that people in a community, municipality, department or country live.

Life Plan: Outline of the path a person can follow to achieve their goals and development in life in terms of short, mid and long term goals. 


\section{Welcame}

Welcome the participants and take attendance. Share with them that today they are going to develop their life plan.

\section{Topic intraduction}

We have learned important lessons about the lives of women and girls in this community, things about human rights, gender, women's health, finances, etc.

All the topics are part of our everyday lives. Ask and write down their answers on a flipchart.

\section{What topics have caught your attention?}

In the last session you all though about which of the community's needs you would like to support and what goals you have for your lives. We are going to listen to everyone now to get to know

the richness that this group has to give our families, schools and friends.

Let participants share their previous work.

Play games that involve setting goals and overcoming obstacles, such as an obstacle

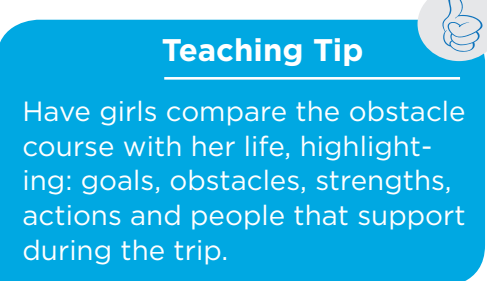
during the trip. course.

\section{Theory and definition}

Follow instructions in the life plan poster considering their concept of what a life plan is and the elements that are part of their life plan.

\section{Application in daily life}

Have participants fill out their life plan posters following the steps proposed in the poster. Let them comment with friends while working but emphasize on the importance of each girl thinking about her own life.

Arrange for a community meeting in which girls will be presenting their life plans to family and community members. 


\section{1) I make my own decisions}

\begin{tabular}{|l|}
\hline OBJECTIVES \\
By the end of this session, participants \\
will have: \\
- Described the types of dating in the \\
community and how they affect their \\
lives. \\
- Identified situations in which women \\
make the decision whether or not to \\
have sexual intercourse. \\
- Determine the reasons that young \\
women in the community decide to \\
start or wait to begin their sexual \\
lives. \\
\hline
\end{tabular}

MATERIALS
- Marker and flipchart
- Masking tape
- Story for a skit
- Objects for the obstacle
course
- Papers to cover their
eyes
- Plaster
- Worksheet

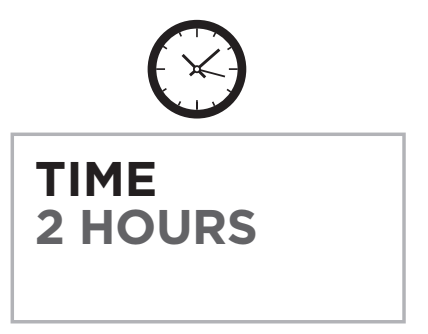
my own informed decisions and the opportunity to act according to what

I have decided. In a relationship, autonomy allows each person to

develop according to his or her desires, goals and needs. To exercise autonomy,

it is necessary to have strongly

cemented self-esteem, to know your

own goals and desires and to have

sufficient information. 


\section{Welcame}

Welcome the participants and take attendance. Tell the participants that today they are going to talk about dating.

\section{Topic introduction}

Play an obstacle course with the participants. In a large open space make an obstacle course by making two paths with things in the way that interrupt the path. You can use trashcans, milk jugs, desks, chairs, balls, etc. Before coming up to the obstacle course, ask for three couple to volunteer and let the rest of the participants know that they will be observers. Let each pair know that they are going to pass together through the obstacle course in different conditions:

Pair 1: one of them will be blindfolded and the other will not.

Pair 2: both will be blindfolded.

Pair 3: neither one will be blindfolded.

Ask them to go through the obstacle course one by one, starting with the pair where both are blindfolded, then the pair where one person is blindfolded and finally the pair where neither is blindfolded. Ask each pair how the felt going through the obstacle course and invite the observers to comment on what they saw happen.

Then ask the group:

What behaviors between couples made it easier to go through the obstacle course?

What behaviors between couples made it harder to go through the obstacle course?

How is life similar to the obstacle course?

How can couples support each other in difficult situations?

What are relationships between couples like in your community?

What parts of dating in your community do you like?

What don't you like about dating?

What do boys expect of their girlfriends once they start dating?

How are girls pressured to start having sex?

\section{Theory and definition}

Complete the activity, "Saying when and with who I want to start my sex life." *Ask for five volunteers to prepare to present a skit to the other participants.

*The rest of the group will participate in a discussion about what relationships are like and when they have to decide about their sex lives.

After volunteers present have a group discussion about why young women in the community accept pressure to have sex and why they might not. Write them down and two flipcharts with each one titled: Reasons to say yes/Reasons to say no.

Talk with participants about the difference between desired sex, voluntary sex and forced sex. Place the three words Desire, voluntary and force on a flip chart and ask volunteers to come up and write synonyms for each. Then go through their answers coming up with a definition.

\section{SAsk:}

What do you think desired, voluntary and forced sex are?

Desired: both people voluntarily want to have sex and have consented to it without any pressures.

Voluntary: One person pressures the other to have sex through emotional manipulation or other means. The other person accepts against her desire.

Forced: One person forces the other, who has expressed no desire to have sex, against her will.

What is the difference between desired sex and voluntary sex?

Ask them to give their own examples of each type and explain that they can also apply these ideas to the way they start their sex life. Reinforce each one along with their differences.

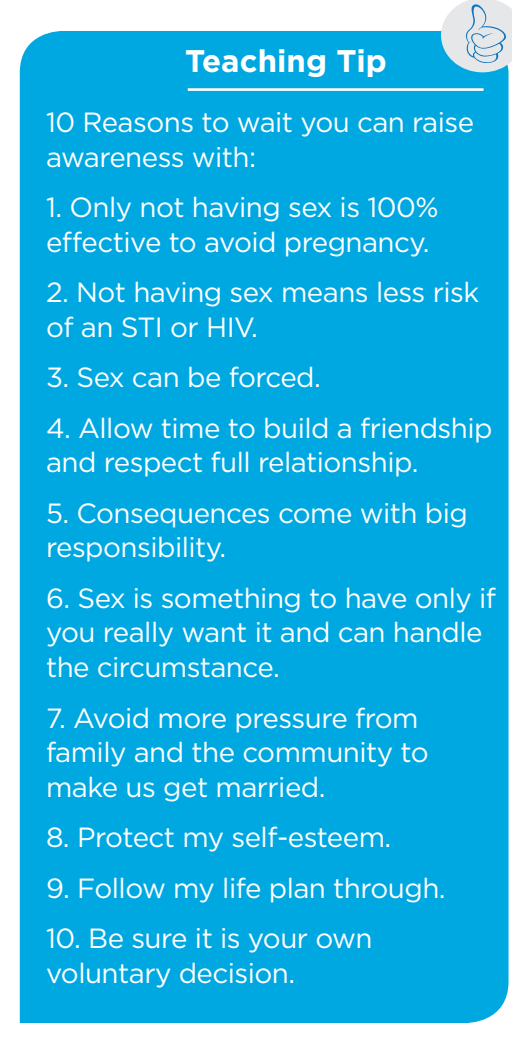




\section{Application in daily life \\ Review the list they made of why they would say yes to having sexual} relations and identify for each of them if it is a case of sex that is desired, voluntary or forced. Discuss the challenges of making free decisions in the community.

Complete the "My body my rights" worksheet.

\section{Story for skit:}

Maria is 18 years old and is studying her second year of high school. She likes to learn a lot and wants to dedicate herself to working as a teacher after she graduates. She has been Elias' girlfriend for two years. He is preparing to be a mechanic and has two years left before he graduates. They feel like they love each other a lot and Elias insists that Maria proves her love to him by having sex. Maria feels like she loves him but is not sure about starting to have sex with him. Something about it scares her.

One afternoon Elias came home with Maria after Girls Creating Opportunities for a Brighter Tomorrow and she told him what they had learned about women's rights and about contraceptive methods. Since they had walked a lot, they decided to sit down and rest on the side of the road. They were alone and Elias was not really paying attention to Maria. He started to get very close to her and she felt nervous and many mixed thoughts and feelings came to her mind. She couldn't get the feeling of doubt out of her mind.

\section{What can María do?}

Why do girls like María accept pressure to have sex?

Why do girls like María not accept pressure to have sex? 


\section{My Body My Rights}

The following represents the rights of

(name)

To treat myself with love and respect

I am going to

I am going to

I am going to

I am capable of achieving my dreams and everyone should treat me well.

I want my father to

I want my mother to

I want my boyfriend or spouse to

I want my friends to

I want my teacher to 


\section{2) Learning about STIs and HIV/AIDS}
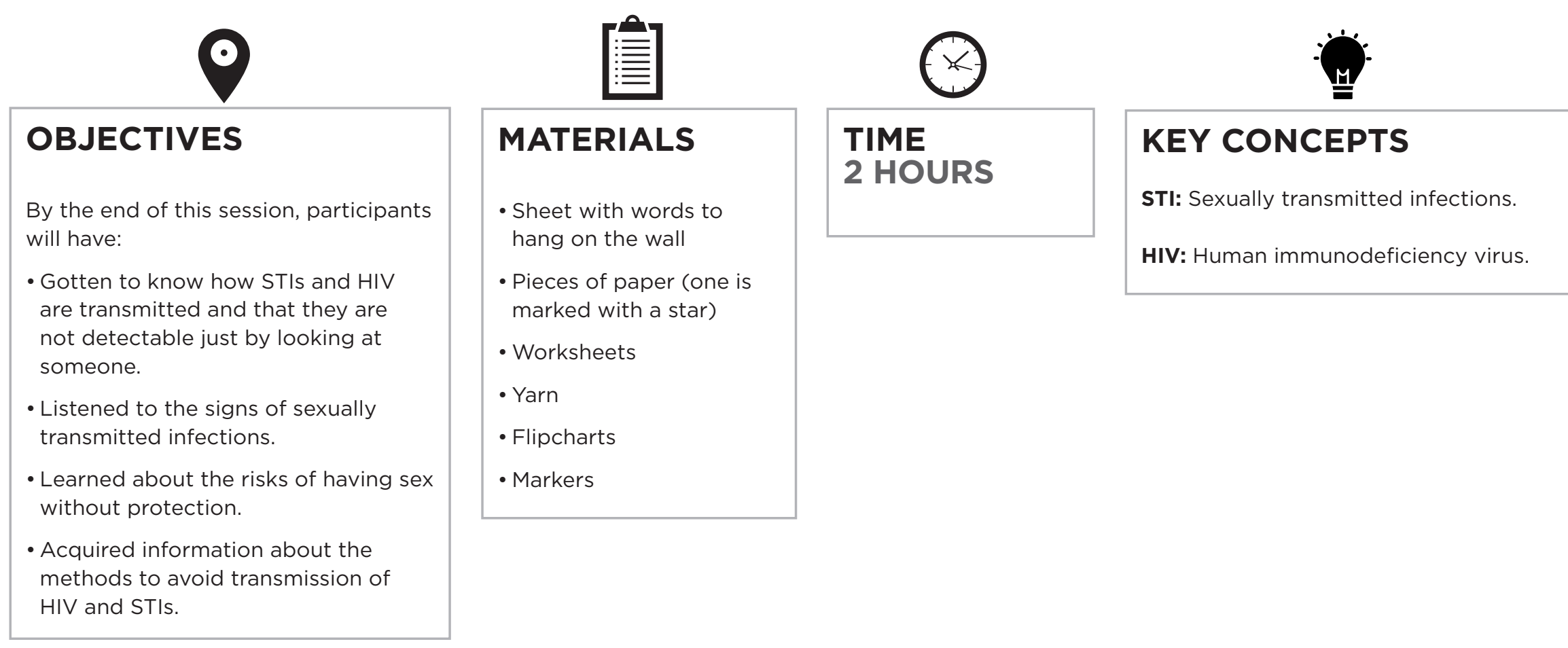


\section{Welcame}

Welcome the participants and take attendance. Share with them that today they are going to learn about sexually transmitted diseases and HIV/AIDS. Ask the participants to make a list of the consequences of having sexual intercourse. Write down the consequences in a column on a flipchart. Allow them to identify both the positive and negative consequences.

What consequences, positive or negative, could there be to having sexual intercourse?

\section{a. Pregnancy \\ b. Pleasure \\ c. Infection \\ d. HIV/AIDS}

\section{e. Closeness with your partner}

\section{f. Violence, being forced to have sex}

\section{g. Pain and sadness}

What prevention methods do you know?

\section{Topic introduction}

Play: Hunt for signatures. Give a piece of paper to each participant and tell them that they are all famous women that are successful and admired by everyone. Each girl should think about what she does as a leader and why she is famous. The goal is to mingle with other leaders in the room and exchange signatures with them. The goal is to exchange with at least three people. Give 5 minutes to get as many signatures from other participants and when they finish, ask them to form a circle.

Ask the person that has the star on their paper to come forward and share with the group that this person has an illness. Tell them that the sickness is an infection and it is transmitted through exchanging signatures with other people. Invite everybody that exchanged signatures on this marked paper to come to the front. And ask:

If these three people have contracted the illness because they exchanged signatures on the marked paper, who else could be infected as well?
Ask the people who signed the other three papers to come forward and continue with each new group until everyone comes forward. Have them count how many have been infected by exchanging signatures and ask:

How is it possible that so many from the group ended up with the infection? How many times did you exchange signatures with someone else? Who runs the highest risk of infection? How could the infection be prevented?

\section{Theory and definition}

Present a poster with the letters STls written vertically and tell them that the three letters form the name of the infections that can be contracted by having sexual intercourse. Ask them to write a word for each letter that describes the infections. Give them a minute to answer and if they don't write what each letter stands for, write the correct answers in the following form:

\section{Sexually \\ Transmitted \\ Infection}

Let participants share everything they know about STIs. Let them go through flyers and leaflets that have scientific information concerning STIs and find the answers to the following questions:

What are STIS?

How are STIs transmitted?

How can babies have an STI?

What symptoms do ST/s present?

Vaginal fluid of any color or with a bad odor

Pain in the area below the abdomen

Drip or liquid coming from the penis

Itching, burning or pain in the genital or anal area

Blemish, sores or blisters on the penis or vagina

Deficiencies in your immune system 
What should I do if I see that my partner has one of these symptoms? Abstain from sexual intercourse with him until he finishes treatment

\section{Recommend that he go to the health center}

Ask if he has an infection

\section{Go to the health center to get yourself checked}

What should I do to take care of my health if I see that I have one of these symptoms?

Go to the health center and follow the treatment given

\section{Abstain from sexual intercourse}

\section{Let my partner know about the situation}

If one partner in a sexual intercoursehip has symptoms, why should the other partner be treated as well?

Put a poster next to the STIs poster that says HIV/AIDS (with the same vertical alignment) and ask the participants to share what they know about HIV/AIDS. Fill out the poster with the meaning of each letter.

Play Myth/Truth about HIV/AIDS. Divide the room in half and explain that one side is myths and the other truths. The participants should stand in the center of the room. You will read them a sentence from the sheet of Myths/Truths and they should run from one side to the other according to what they believe about what you read. Explain the correct answer and give them additional information about what you read to them. Later they should all return to the center of the room for the next myth/truth sentence. Start the game and say:

I can know if someone is infected with HIV just by looking at them. MYTH: a person in the symptomless period can appear completely healthy

Condoms help to prevent the transmission of HIV.

TRUTH: The best way to prevent HIV is to not have sex. If you are going to have sex using a condom correctly is a way of prevention because it limits the exchange of certain body fluids between, even though it is might not be $100 \%$ effective.

Only people that have several sexual partners are at risk of getting HIV. MYTH: Being with one partner does not ensure that he/she does not have HIV. It is important to have medical assurance that your partner does not have HIV.
There is not a cure or a vaccine to fight HIV.

TRUTH: Even though there are treatments to extend the length of life, there is not a cure or a vaccine and the person dies with very low defenses from other illnesses.

\section{Application in daily life}

Hand each participant a "Thinking about having sexual intercourse" worksheet. Invite them the questions presented. And then have them read and complete the "How can you avoid HIV and STIs?" worksheet as well. 
'GIRLS CREATING OPPORTUNITIES FOR A BRIGHTER TOMORROW' PROGRAM

INTEGRATED CURRICULUM GUIDE

\section{Thinking About Having Sexual Intercourse}

Section A
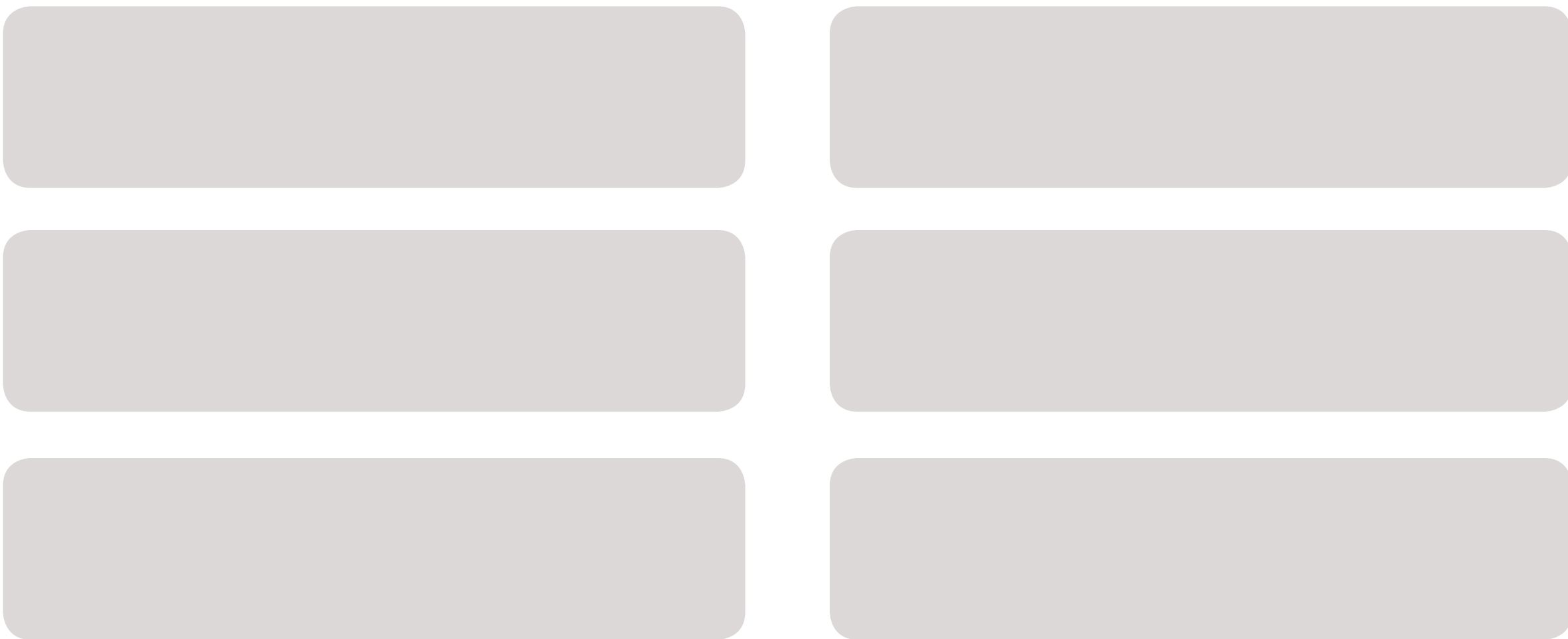


\section{Thinking About Having Sexual intercourse}

Section B
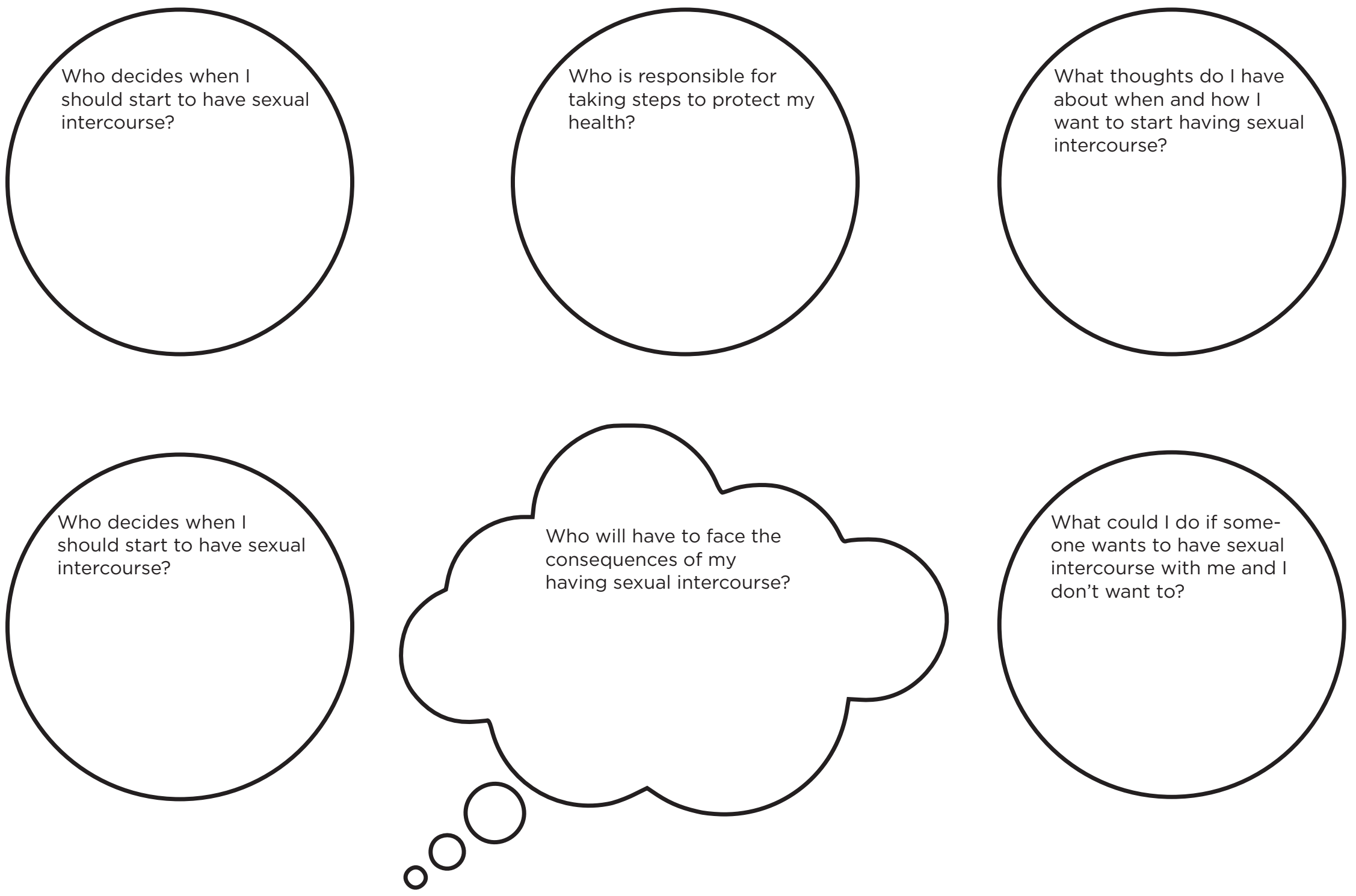


\section{How Can I Avoid HIV And STIs?}

\section{Abstinence:}

refers to not having sexual intercourse.

\section{Caresses:}

limits physical encounter to just giving hugs and kisses.

\section{Fidelity}

when both people have only one partner and neither of them have HIV or another STI.

Use of new disposable syringes and needles:

every time you get injected or tattooed.

\section{Correct and consistent use of a condom} every time you have sexual intercourse.

I would feel good using: 


\section{3) Family planning}

\begin{tabular}{|c|c|c|c|}
\hline $\begin{array}{l}\text { OBJECTIVES } \\
\text { By the end of this session, participants } \\
\text { will have: } \\
\text { - Learned about the diverse methods } \\
\text { of family planning. } \\
\text { - Understood the advantages and } \\
\text { disadvantages of the different } \\
\text { methods. }\end{array}$ & $\begin{array}{l}\text { MATERIALS } \\
\text { - Worksheet } \\
\text { - Reading sheet } \\
\text { - Flipcharts } \\
\text { - Markers }\end{array}$ & $\begin{array}{l}\text { TIME } \\
2 \text { HOURS }\end{array}$ & $\begin{array}{l}\text { KEY CONCEPTS } \\
\text { Family planning: Every couple can } \\
\text { decide how large they want their } \\
\text { family to be. To do this they can } \\
\text { use different methods to prevent } \\
\text { pregnancy, take more time between } \\
\text { one child and another, and also to } \\
\text { protect the mother's health. Married } \\
\text { men and women as well as people who } \\
\text { are dating can use planning methods. } \\
\text { All men and women have the right to } \\
\text { family planning and health services that } \\
\text { provide the necessary information to } \\
\text { use the contraceptives. }\end{array}$ \\
\hline
\end{tabular}




\section{Welcame}

Welcome the participants and take attendance. Share with them that today they are going to learn about family planning and how to do it.

\section{Topic introduction}

Form three groups. Give each group a flipchart with one of the following questions and ask them to discuss and write/draw answers on the flipchart. Have every group present to the others.

Flipchart 1: What does family planning refer to?

Flipchart 2: What family planning methods have you heard about? Flipchart 3: Why is it difficult to talk about family planning in our communities?

\section{Theory and definition}

Divide the participants into groups. Each group is going to have flyers and pamphlets about one of the most accessible family planning methods in the community.

Every group should read and understand the method that has been assigned to them. They are going to do an interpretive dramatization of a couple looking for a

contraceptive method at the health center. The group has to include information about the method: how it works, what it does to the body, methods of administration, security, advantages and disadvantages of its use. Insist on each group mentioning what rights support family planning.

Finish by going through the reading sheet with information about the family planning methods with the participants and create a chart together.

\section{Application in daily life}

Discuss with the participants that sometimes for one reason or another young women in the community are married/united at a very young age and quickly become pregnant. The two things greatly affect the possibility of them achieving their plans. At the least if they get married they can look for a way to prevent pregnancy with a contraceptive method.

Handout the "To have a child before I am ready, willing and desiring to" worksheet and ask them to write down three methods that would prevent this from happening. They can then read the content sheet "Contraceptive Methods" and use the information to complete the "Methods" exercise writing down the method that catches their attention the most in each space, while marking its accessibility in the form of stars.

1 star= This method is not accessible, it is expensive, I don't know where to find it.

2 stars= This method is accessible, but I would not be willing to use it

3 stars $=$ This method seems easy to use and find.

After marking the methods with stars, ask:

What contraceptive methods did you give 2 or 3 stars?

Write them down on a flipchart and ask:

Where could you get them?

Where could you get more information about them?

Ask them to write the info down on their worksheet as well. 


\section{Contraceptive Methods}

Abstinence: This method consists of not having sexual intercourse.

Rhythm or Calendar Method: This method consists of preventing pregnancy by observing the changes in a woman's body to determine when her fertile period is and not having sexual intercourse during this period. It is ONLY EFFECTIVE IN WOMEN WITH EXACT MENSTRUAL CYCLES.

Male Condom: A sack shaped object made from latex, that is placed on the erect penis before having sex. It serves as a barrier that contains semen from the woman's vagina during intercourse.

Intrauterine device (IUD): A smooth, small apparatus in a T shape, made from different materials (can be copper or plastic) that is positioned inside a woman's uterus by a professional health care person. It avoids reproductive cells from implanting in the uterus walls (the plastic ones have hormones).

The Pill: The contraceptive pill is taken daily a woman while she does not want to become pregnant. The pill has a dosage of hormones that avoid de body from ovulating each month. If one pill is missed the risk of becoming pregnant increases.

Diaphragm: A diaphragm is a form of birth control that's a shallow cup shaped like a little saucer that's made of soft silicone. You bend it in half and insert it inside your vagina to cover your cervix.

Injectable contraceptives: Injections that come in a set dosage that provide protection for one, two or three months.

Spermicides: come in several different forms like cream, gel, foam, film, and suppositories. Most spermicides contain a chemical that kills sperm. Spermicides can be used alone but are more effective when used with another method of birth control, such as a condom or diaphragm.

Lactational amenorrhea method (LAM): Can be practiced while a mother is exclusively breastfeeding the baby. It lowers the risk of pregnancy, but does not completely avoid it. This method is not very effective. Sometimes even mothers who are breastfeeding get pregnant. 
'GIRLS CREATING OPPORTUNITIES FOR A BRIGHTER TOMORROW' PROGRAM INTEGRATED CURRICULUM GUIDE

\section{Contraceptive Methods}

To have a child before I am ready, willing and desiring to
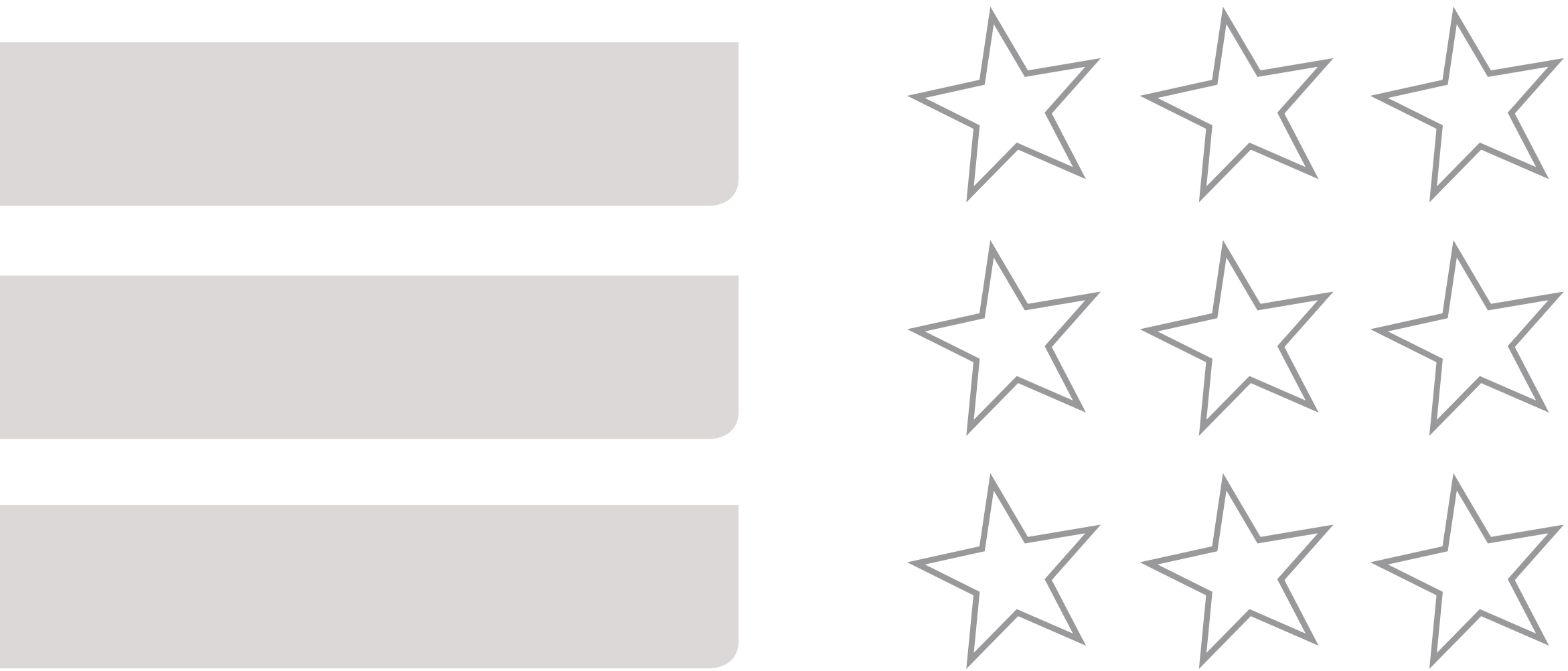


\section{4) I am a contribution to development}

OBJECTIVES
By the end of this session, participants
will have:
- Understood what human
development is and how you reach it.
- Proposed actions to promote in
their community to improve human
development.

MATERIALS
- Work completed by
participants from session
5.6 of last trimester
- Health and
Empowerment Activity 7
and 9

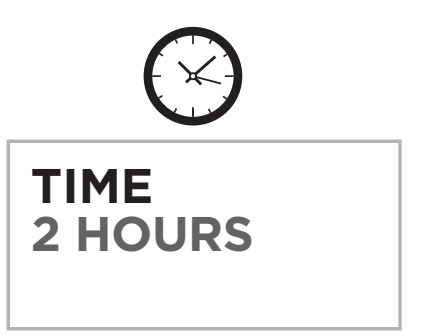

KEY CONCEPTS
Human development: Considered
the quality of life that people have,
it should constantly be improving.
Defined by life quality according to
education level, income and years that
people live.




\section{Welcame}

Welcome the participants and take attendance. Share with them that today they are going to identify how valuable each of them is to the human development of their community. Start by recognizing the qualities and strengths that they have and can put forth towards the development of the community by playing "The Bottle of Good Things."

Sit the participants in a circle and place the bottle in the center. Have someone begin by spinning the bottle and when the bottle stops they should mention the participant that it is pointing to, strengths she has and how she could put them to use for the community's development.

\section{Topic introduction}

Return their work from session 5.6 and ask them to read over their work individually and underline something the person they interviewed said that motivates them to work for the community.

Have them get together into groups of four and each person will share the answers to the questions that they asked the person they interviewed. While they are sharing, everyone should be listening attentively and identifying phrases or words that grab their attention. Afterwards every group should choose and write down one sentence that inspires them to work for the community and write it on a flipchart. They can create these phrases from listening and copying down the answers everyone shared.

All the groups will present their phrases and explain why they chose them. Encourage the conversation about their commitment to the community and how supporting the community opens opportunities for them as well.

S Ask:

What have you learned from the people that you interviewed and these phrases?

How has the community changed thanks to these people's work?

What things do you believe you could do?

What feelings did these people express about their lives?

\section{Theory and definition}

Read the definition of human development that is in the key concepts and have them remember which sustainable development interested them. Participants will make a list of all the things that they have learned since being in Girls Creating Opportunities for a Brighter Tomorrow that they can use to achieve human development. Write down their answers on a flipchart and use them for the following activity.

\section{Ask:}

What things have you learned from Girls Creating Opportunities for a Brighter Tomorrow?

\section{Negotiate so both parties win}

Know your human rights

Know how to care for self-esteem

Communicate assertively to defend myself

Contact and communicate with community leaders

How to help a pregnant woman identify signs of risk

\section{Prevent HIV/AIDS}

Decision making

Change conflicts

Work on a team with other women

Take care of myself and other women in the community

\section{Application in daily life}

Ask each participant to individually choose one of the four phrases that inspired her to work for community development on a sheet of paper and make a drawing, song or poem about how their life will be if they apply this phrase to everything they do. Remind them to include the goal that they want to help the community work towards. On the back of the sheet, ask them to write:

-Steps to follow to achieve this life

-Things to strengthen in my life so I can contribute to human development

-My contribution to the community 


\section{community}

OBJECTIVES
By the end of this session, participants
will have:
- Identified the advantages and
challenges that they have to make
in their lives in order to contribute
to the community and the collective
development.
- Prepared a presentation about the
work in the community that they
have supported.
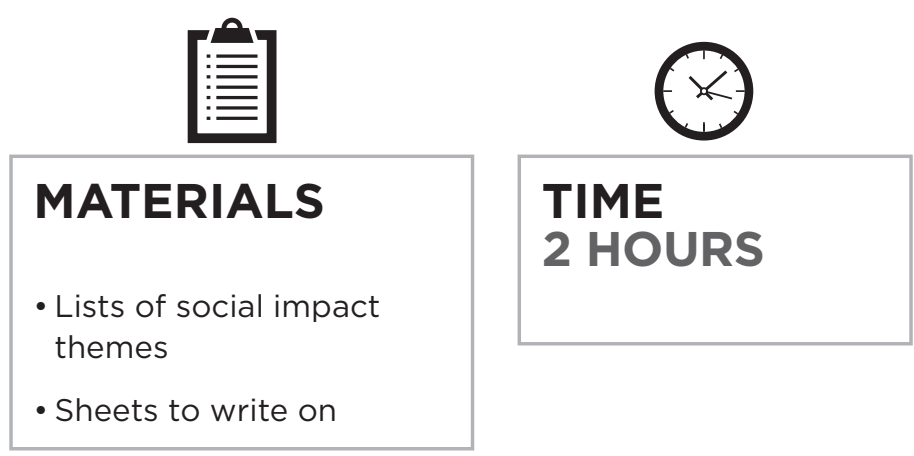


\section{Welcame}

Remember with the participants all of the topics that they have studied and learned about during these sessions. Say to them:

We have learned about important topics for their lives of women and girls in this community, things about human rights, gender, women's health, finances, etc. All of the topics are part of our everyday lives and of other people's lives as well. What topics interested you the most?

Write down their answers on a flipchart, review them and highlight the ones that have social impact. Invite each participant to choose three topics from the list that interest her most.

\section{Topic introduction}

Ask participants to get together with a partner and share which topics were the most important to them, why and a personal story that relates to them.

Return to the group and have some of the girls share the topics are important to them with the rest of the group. Introduce the theme of working for social change through concrete actions. Begin by exploring campaigns that have happened on global and national levels and then move on to talking about actions done at a local level within the community.

S Say:

Some people participate in large campaigns to make social change.

Can you think of a case of this? (making social change) What changes have these actions brought about?

Sometimes small actions make changes, actions that you take in your own life and the life of your family and community.

What actions could you carry out in your community, family or life to bring about social change around the topics that are important to you?

What risks are there for a person who works for social change around the topics you have chosen?

What can you do for social change around this topic?

\section{Theory and definition}

Invite girls to include their interests in working for certain social changes in their life plans. Hand out life plan posters to each participant and follow the activities suggested. Make sure each participant develops her own life plan and includes her contribution towards change in her community.

\section{Application in daily life \\ Tell the participants that they will have a closing session where they pres-} ent the work that they have done along with their life plans to their families community leaders and people who have supported them during the course. Choose a date for the event with the participants. Take a few weeks to prepare and invite people to the activity.

Begin by making lists of the following with participants:

1. People they want to invite to the activity

2. Things that they would like to present

3. Ideas and goals that they want to share

Help the group prepare the agenda for the meeting, and decide who will be in charge of preparing and presenting each point. Make sure that all the participants have something important to do in the session: welcoming guests, confirming attendance, leading the agenda, preparing crafts and work to put on display, sharing life plan

Make sure to include:

- $\quad$ Presentation about what Girls Creating Opportunities for a Brighter Tomorrow is

- Participants testimony on "What changed in my life since I joined the program?"

- We want to contribute what we have learned in Girls Creating Opportunities for a Brighter Tomorrow to the community.

- $\quad$ Share what we have made in Girls Creating Opportunities for a Brighter Tomorrow

- Life plans

- Gratitude to community leaders and family for their support. 
The Population Council confronts critical health and development issues-from stopping the spread of HIV to improving reproductive health and ensuring that young people lead full and productive lives. Through biomedical, social science, and public health research in 50 countries, we work with our partners to deliver solutions that lead to more effective policies, programs, and technologies that improve lives around the world. Established in 1952 and headquartered in New York, the Council is a nongovernmental, nonprofit organization governed by an international board of trustees. 